DOE/CS/24330-T3

(DE84000423)

\title{
AN ECONOMIC AND ENGINEERING ANALYSIS OF A SELECTED FULL-SCALE TROMMEL SCREEN OPERATION
}

Final Report

By
G. Joe Hennon
Douglas E. Fiscus
John C. Glaub
George M. Savage

October 1983

Wurk Performed Under Contract No. AC03-80CS24330

Midwest Research Institute

Kansas City, Missouri

Technical Information Center

Office of Scientific and Technical Information United States Department of Energy 


\section{DISCLAIMER}

This report was prepared as an account of work sponsored by an agency of the United States Government. Neither the United States Government nor any agency Thereof, nor any of their employees, makes any warranty, express or implied, or assumes any legal liability or responsibility for the accuracy, completeness, or usefulness of any information, apparatus, product, or process disclosed, or represents that its use would not infringe privately owned rights. Reference herein to any specific commercial product, process, or service by trade name, trademark, manufacturer, or otherwise does not necessarily constitute or imply its endorsement, recommendation, or favoring by the United States Government or any agency thereof. The views and opinions of authors expressed herein do not necessarily state or reflect those of the United States Government or any agency thereof. 


\section{DISCLAIMER}

Portions of this document may be illegible in electronic image products. Images are produced from the best available original document. 


\section{DISCLAIMER}

This report was prepared as an account of work sponsored by an agency of the United States Government. Neither the United States Government nor any agency thereof, nor any of their employees, makes any warranty, express or implied, or assumes any legal liability or responsibility for the accuracy, completeness, or usefulness of any information, apparatus, product, or process disclosed, or represents that its use would not infringe privately owned rights. Reference herein to any specific commercial product, prosess, or servire hy trade name, trademark, manufacturer, or otherwise does not necessarily constitute or imply its endorsement, recounmendation, or favering by the United States Governmont or any agency thuicuf. The views and opinions of authors expressed herein do not necessarily state or reflect those of the United States Government or any agency thereof.

This report has been reproduced directly from the best available copy.

Available from the National Technical Information Service, U. S. Department of Commerce, Springfield, Virginia 22161.

Price: Printed Copy A11

Microfiche A01

Codes are used for pricing all publications. The code is determined by the number of pages in the publication. Information pertaining to the pricing codes can be found in the current issues of the following publications, which are generally available in most libraries: Energy Research Abstracts (ERA); Government Reports Announcements and Index (GRA and I); Scientific and Technical Abstract Reports (STAR); and publication NTIS-PR-360 available from NTIS at the above address. 
AN ECONOMIC AND ENGINEERING ANALYSIS OF A SELECTED

FULL-SCALE TROMML SCREEN OPERATION

by

G. Joe Hennon and Douglas E. Fiscus

Midwest Research Institute

Kansas City, Missouri 64110

John C. Glaub and George M. Savage

Cal Recovery Systems, Inc.

Richmond, California 94804

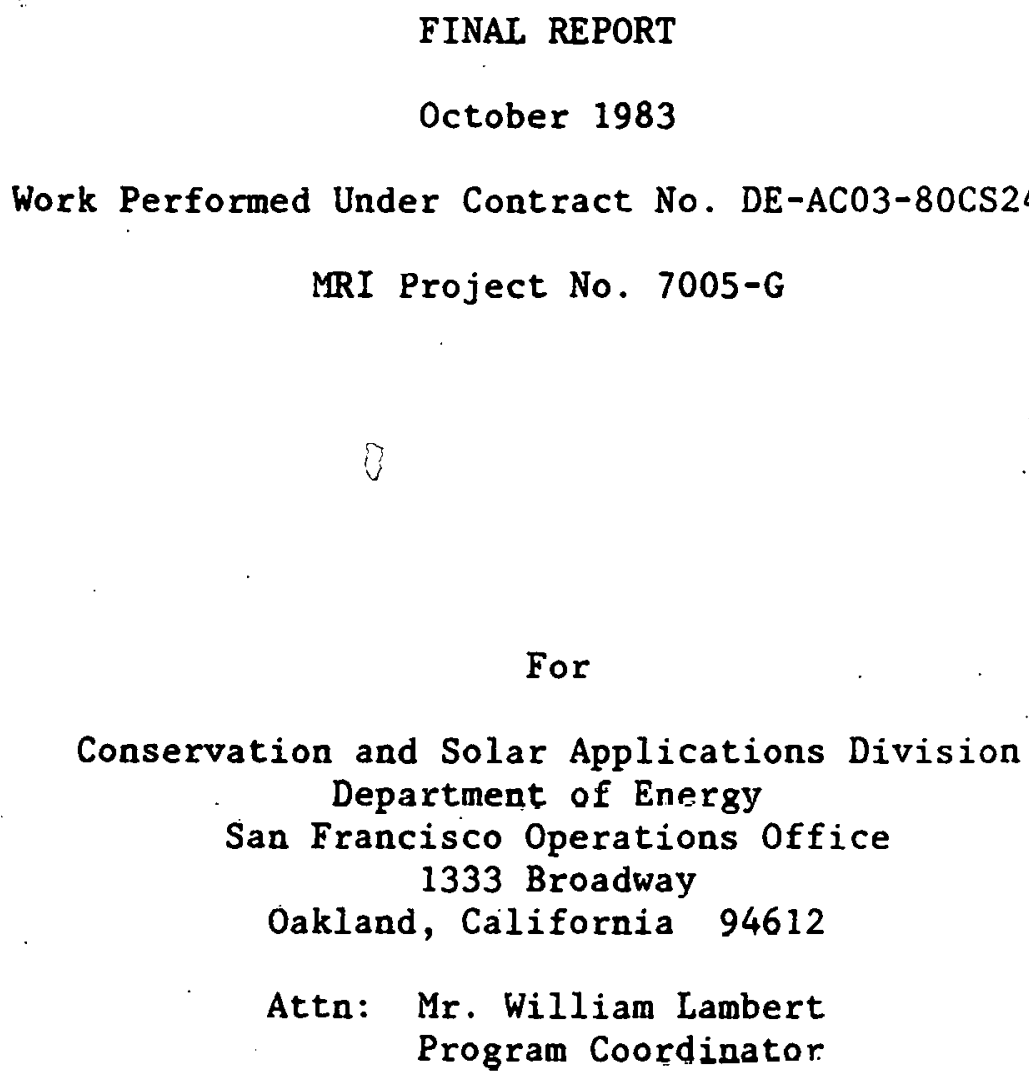


PREFACE

Midwest Research Institute (MRI) assisted by. Cal Recovery Systems, Inc. (CRS) as a subcontractor has conducted a program entitled "An Economic and Engineering Analysis of Selected Full-Scale Rotary Screen Operations." The evaluation of the rotary screen (trommel) was conducted at the Baltimore County Municipal solid waste facility in Cockeysville, Maryland, and was sponsored by the Department of Energy (DOE) under Contract No. DE-AC03$80 \operatorname{cs} 24330$.

This document is the final report and is for the period August 1 , 1980, through November 26, 1982, according to the directive of the Program Coordinator.

MRI personnel contributing to this program include Mr. Douglas E. Fiscus, Head, Applied Sciences Section, Mr. G. Joe Hennon, Program Manager, Applied Sciences, who served as Project Manager, Mr. Gary Hinshaw, Junior Chemist, Mr. Patrick Hogan, Assistant Engineer, Mr. Gary Kelso, Senior Chemical Engineering Economist, and Ms. Karin Bauer, Associate Statistician. CRS personnel participating in the program were Mr. George Savage, Mr. Daniel Jones, Mr. Donald Lafrenz, and Dr. John Glaub.

Approved for:

MIDWEST RESEARCH INSTITUTE

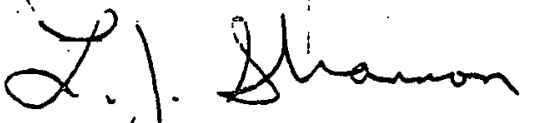

I. J (Shannon, Executive Director

Engineering and Applied Sciences

Division

October 1983 


\section{ABSTRACT}

The trommel screen located at the Baltimore County municipal solid waste processing plant operated by Teledyne National was evaluated for a 1-year period. This trommel is used to remove noncombustibles from refuse derived fuel (RDF) and thereby reduce ash content and increase.heating value of the RDF. The trommel is $8 \mathrm{~m}$ in length, $3.7 \mathrm{~m}$ in diameter, has $32-\mathrm{mm}$ holes, and can be operated at 6 to $12 \mathrm{rpm}$. Economic operating and maintenance data were collected for the period November 1980 through October 1981. Trommel performance was measured during October 1980 and January, May, and August 1981 in order to determine performance during the four seasons of the year. Test runs were conducted to evaluate screening. performance as a function of feedrate and rotational speed.

Physically, the trommel can convey infeed rates as high as $46 \mathrm{Mg} / \mathrm{h}$, but screening efficiency decreases with increased feedrates. An infeed range of 7 to $13 \mathrm{Mg} / \mathrm{h}$ is practical as this insures the greatest probability of meeting fuel specifications and achieving optimum economic contribution. While high screening efficiencies can be achieved at low feedrates, the value of the heating value increase may not always offset the trommel cost below a feedrate of $5 \mathrm{Mg} / \mathrm{h}$.

The effect of rotational speed is not pronounced because of the effect of lifter bars inside the trommel which tend to lift the material to the same height before dropping, regardless of rotational speed. The trommel removes both ash and moisture from the RDF because the undersize material has higher contents of both. Therefore, the heating value and organic content of the fuel is improved and the amount of improvement tends to decrease with increasing feedrate. Fuel quality improvements are achieved by removing a significant amount of the undersize, which contains much combustible material. Therefore, consideration needs to be given to further processing of the undersize.

Seasonal variations occurred in the feed to the trommel, for example as a consequence of the higher percentage of lawn and garden waste present in spring and summer. Seasonal variations were manifested in varying particle size, ash content, moisture content, organic content, and heating value. However, no obvious trend of trommel performance versus season of the year was observed. 
THIS PAGE

\section{WAS INTENTIONALLY LEFT BLANK}




\section{CONTENTS}

Preface. . . . . . . . . . . . . . . . . . . . . . . . ij

Abstract . . . . . . . . . . . . . . . . . . . . . . . . .

Figures. . . . . . . . . . . . . . . . . . . . . . . . . . . vii

Tables . . . . . . . . . . . . . . . . . . . . . . . . . ix

Acknowledgment . . . . . . . . . . . . . . . . . . . . . . . . $x$

1.0 Introduction . . . . . . . . . . . . . . . . . . . . 1

1.1 Background . . . . . . . . . . . . . . . . . . . 1

1.2 Discussion of rotary screens . . . . . . . . . . 1

2.0 Conclusions and Recommendations. . . . . . . . . . . . . 5

2.1 Conclusions. . . . . . . . . . . . . . . . . . . 5

2.2 Recommendations. . . . . . . . . . . . . 6

3.0 Site and Facilities Description. . . . . . . . . . . . . . 7

3.1 General facility description... . . . . . . 7

3.2 Trommel description. . . . . . . . . . . 26

3.3 Trommel variables. . . . . . . . . . . . . 26

4.0 Field Testing Procedure. . . . . . . . . . . . . . . 35

4.1 Trommel test conditions. . . . . . . . . . . . 35

4.2 Field data collected............. . 35

4.3 Samples collected for laboratory analysis. . . . 37

4.4 Field test schedule. . . . . . . . . . . . . . . 38

4.5 Field testing problems............. . 41

5.0 Laboratory Analys is Procedures............ . . . 43

5.1 Subsampling of gross samples.......... . 43

5.2 Air-dry moisture analysis. . . . . . . . . . . . 43

5.3 Sizp distribution analysis... . . . . . . 43

5.4 Composition analysis..... . . . . . . . . 43

5.5 Oven-dry moisture analysis... . . . . . . . . 44

5.6 Ash content analysis... . . . . . . . . . . . 44

5.7 Heating value analysis... . . . . . . . . 44

6.0 Test Results....................... 45

6.1 Operation and performance. . . . . . . . . 45

6.2 Seasonal variations. . . . . . . . . . . . . 46

7.0 Performance Characterization . . . . . . . . . . . . 53

7.1 Screening cfficiency................ 53

7.2 Ash content and moisture content removal . . . . 56

7.3 Organic content improvement and organic recovery ................ . 59

7.4 Heating value improvement and energy recovery. . 61

7.5 Trommel energy requirements. . . . . . . . 67 
CONTENTS (continued)

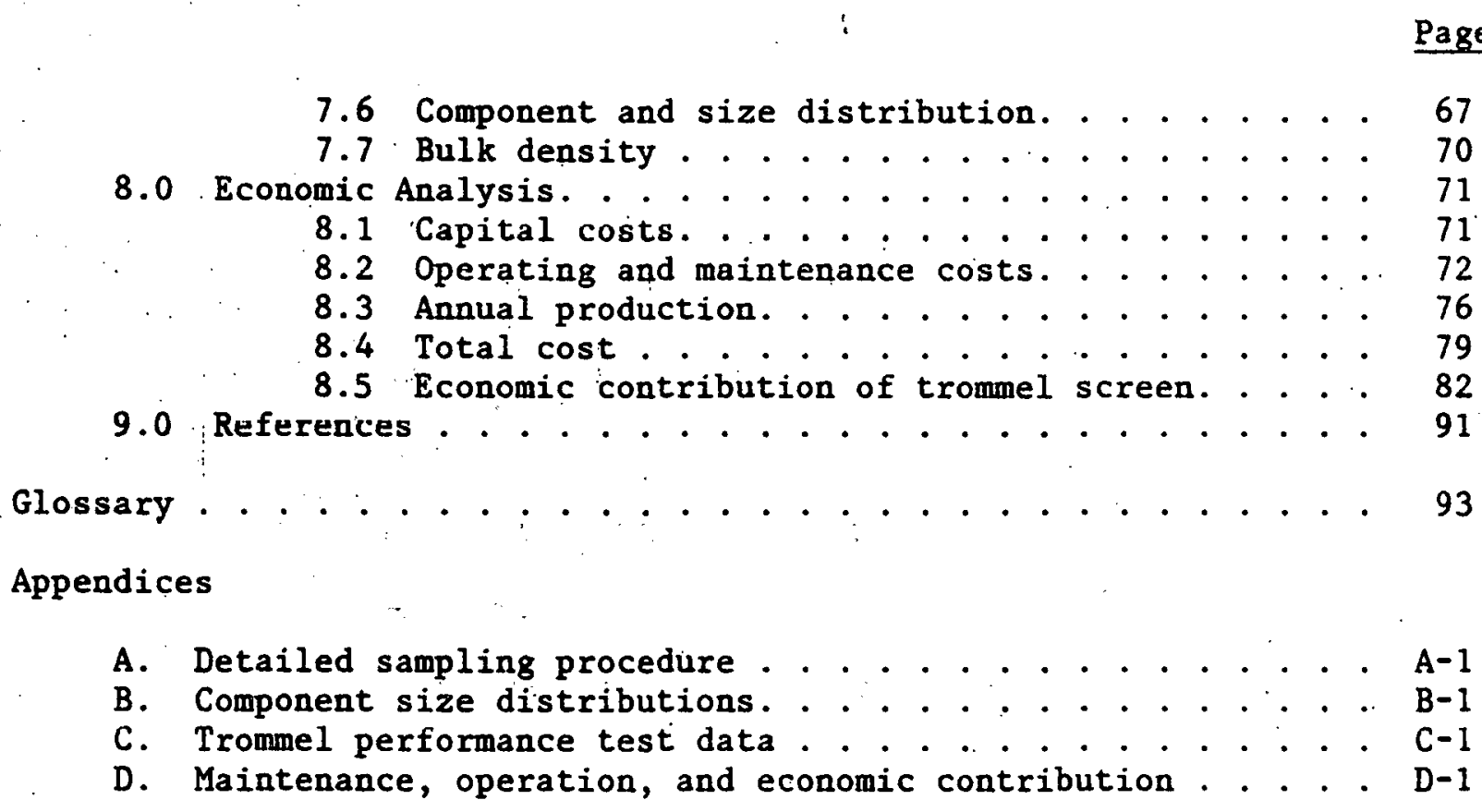




\section{FIGURES}

Number

$\underline{\text { Page }}$

1.1

Trommel (Rotary Screen).

3.1

Schematic Diagram of th

3.2

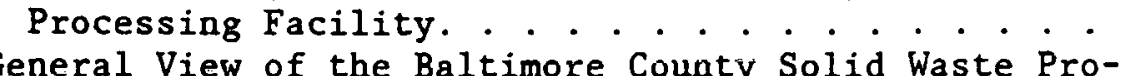

3.3 cessing Facility.

Plot Plan - Baltimore County Solid Waste Processing Plant.

Flow Diagram for Receiving Through Ferrous Recovery, Baltimore County . . . . . . . . . . . . . . . . . . . . 11

3.5

Flow Diagram of RDF Processing, Baltimore County . . . .

Background: Primary Shredder and Inclined Drag Conveyor to Shredder, Foreground: Grate Bars and Hammers, Baltimore County . . . . . . . . . . . . . . . . . 14

7.1 Effect of Feedrate and Rotational Speed on Screening Efficiency .. . . . . . . . . . . . . . . . . 55

7.2 Effect of Feedrate and Rotational Speed on Ash Content and Moisture Content of Oversize... . . . . . . . 58 


\section{FIGURES (continued)}

Number

Page

7.3 Effect of Feedrate and Rotational Speed on Ash Content Removal. . . . . . . . . . . . . . . . . . . 60

7.4 Effect of Feedrate and Rotational Speed on Organic Quality Improvement and Organic Recovery .. . . . . . . . . . 62

7.5 Effect of Feedrate and Rotational Speed on Heating Value of Oversize Fraction.................. 63

7.6 Effect of Feedrate and Rotational Speed on Heating Value Improvement and Energy Recovery. . . . . . . . . . . 65

7.7 Effect of Feedrate and Rotational Speed on Ash Production Per Unit Energy. .. . . . . . . . . . . . . . . . 66

7.8 Comparison of Heating Value and Organic Content. . . . . . 68

7.9

8.1

8.2

8.3 Truminel Eirergy Requirements Vcrouo Infecd Rate. . . . . . $\quad 5 \dot{y}$ Oversize Heating Value Compared to Fuel.Specification. . . 84 Oversize Ash Content Compared to Fuel Specification. . . . 85

8.4

Oversize Heating Value Versus Ash Content. . . . . . . . . 86

Economic Contribution of the Trommel . . . . . . . . . . . 89 
3.1 List of Equipment. . . . . . . . . . . . . . . . . 24

4.1

4.2

.4 .3

4.4

4.5

4.6

6.1

7.1

8.1

8.2

8.3

8.4 Seasonal Test Schedule.... . . . . . . . . . . . 35 Summary of Types of Field Data Collected. . . . . . . . . 36 Matrix of Test Series No. 1. . . . . . . . . . . . 38 Matrix of Test Series No. 2. . . . . . . . . . . . 39 Matrix of Test Series No. 3. . . . . . . . . . . . . . 40 Matrix of Test Series No. 4. . . . . . . . . . . . . . . . 40 Seasonal Variations in Trommel Feed Characteristics. . . . 47 Guide to Performance Characterization Plots. . . . . . . . 54 Installed Capital Costs of Baltimore County Resource Recovery Facility. . . . . . . . . . . . . . 73 Monthly Trommel Maintenance. . . . . . . . . . . . . 75 Monthly Operation of Trommel . . . . . . . . . . . . . 77 Trommel and RDF Plant Availability . . . . . . . . . . . 80 
The cooperation of Teledyne National, which operates the Baltimore County Municipal Solid Waste Facility, is gratefully acknowledged. Special thanks go to Mr. Kenneth Cramer and Mr. David Chon for their cooperation. and support. 


\subsection{INTRODUCTION}

\subsection{BACKGROUND}

The combined need for new waste disposal techniques and new energy sources has stimulated considerable interest and activity in the design and construction of waste-to-energy processing plants. A 1978 MRI survey listed over 50 existing or planned systems for the recovery of energy and other materials from municipal solid wastes (MSW). Plants which produce refuse derived fuel (RDF) were among the common types of waste processing plants identified.

Prior to this program, governmental agencies had funded numerous studies of solid waste processing facilities and related facets of the solid waste industry. These studies revealed that no standards had been developed and accepted for plant design, processing flow diagrams, processing equipment selection, and material handling equipment. There were no duplications of plant type and equipment either in operation or being planned. However, problems common to all plants were high operation and maintenance costs, concerns about waste fuel quality, and the need to remove dangerous and hazardous material from the incoming waste stream. Size reduction and separation of various components in the MSW stream are necessary to produce RDF from MSW. Rotary (trommel) screens may be used to aid resource recovery in all of the above listed areas.

The use of trommel screens had been shown to be valid in several resource recovery plants. However, additional research and development work was needed in order to quantify the important engineering parameters. The general objectives of this project were to thoroughly evaluate a full-scale rotary screen and to present the results sn that plant designers, plant operators, and decision-makers will have the best available data on design considerations, construction, and operating parameters of rotary screening systems presented in a concise and understandable manner.

\subsection{DISCUSSION OF ROTARY SCREENS}

Screens are used to extract particlca within a specific size range from an MSW stream. Screens represent a type of separation equipment by which the MSW is segregated by particle size only, instead of by density and particle size as with an air classifier. The screen can be placed anywhere in the sequence of processing steps used for energy and resource recovery; it can be the first piece of equipment, or it can be installed after the shredders or air classifier. For example, a screen may be used to eliminate glass, metals, etc. before size reduction takes place, or it may be used to remove fine material after primary and/or secondary shredding. The need to reduce the amount of ash when $\mathrm{RWF}$ is burned has increased the interest in using rotary screens for glass, grit, and metal removal. 
There are three types of dry screens used in MSW-to-energy systems: vibrating, disc, and rotary (trommel). Vibrating screens are further divided into gyrating and reciprocating. As stated above, the separation accomplished by screens is based on particle size. The openings allow particles smaller than the size of the openings to pass through. The material which passes through the holes is called "unders." The material which does not pass through the holes flows out the end of the screen as "overs." The motion of the screen (in the case of rotary screens, the unit rotates about the central axis of the cylinder) serves three purposes: (a) it allows the particles to come in contact with the screen surface; (b) it minimizes "en-" trapment of small particles; and (c) it aids in moving the MSW down the screen. The screens are generally set at an angle so gravity can also assist in moving the MSW along the length of the screen.

The rolary screen, called a trommel, illustrated in Figure 1.1 is a long metal cylinder with holes in the outer surface. The cylinder ie supported on external bearings to maintain a clear area inside the cylluder. The trommel is rotated by a motor at one end.

Despite the fact that trommel screens have been built and placed in several operating plants, the principles governing trommel screens when MSW is being processed are not well understood. Because designs have been based on limited testing of small-scale units and not on fundamentals verified by large-scale test results, the scale-up and subsequent operation often lead to less than optimum performance.

This; program addressed the issue of evaluating and characterizing a rotary screen as a unit operation in the resource recovery process.

All trommel screens presently in processing facilities are of basically the design that is illustrated in Figure 1.1. The details of the designs vary to suit the specific separation desired. Screen hole size is selected to control the maximum size of the material removed as unders. Some designs use blades called lifters on the inside surface of the trommel to assist in agitating the material. The inclination of the trommel is used to help control the material throughput rate and therefore the length of time the material is exposed to the holes in the screen surface.

Rotary screens placed after shredding or air classification can take advantage of the more uniform size distribution of the material. The openings in the trommel screen can be smaller.

The characterization parameters derived from this study will aid the ultimate comparison of rotary screens of various designs used in different steps of a resource recovery process. This information will also aid in elucidating the fundamentals governing rotary screen performance. 


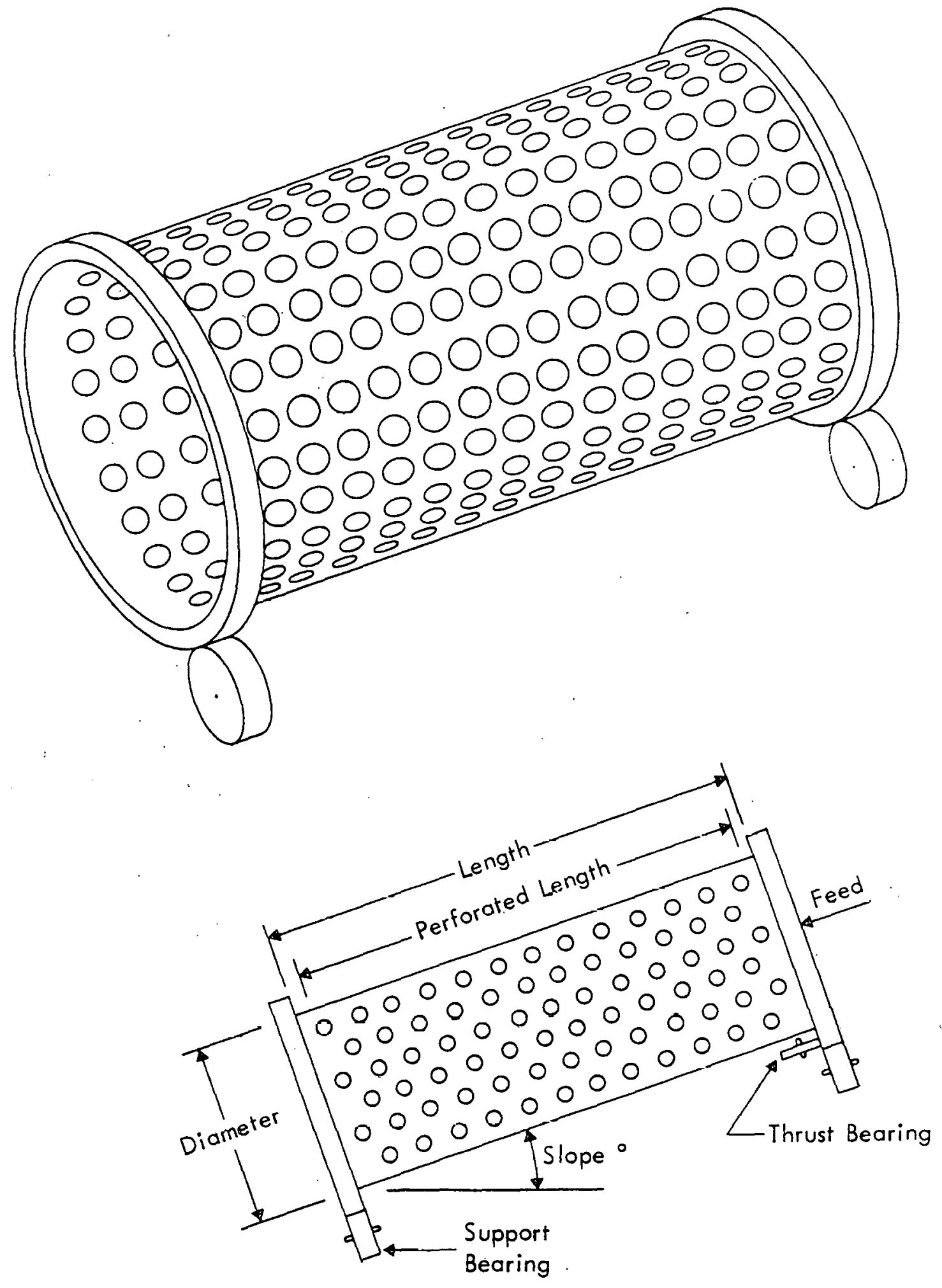

Figure 1.1. Trommel (Rotary Screen). 


\section{THIS PAGE \\ WAS INTENTIONALLY \\ LEFT BLANK}




\subsection{CONCLUSIONS AND RECOMMENDATIONS}

\subsection{CONCLUSIONS}

- The trommel hole size and configuration and the trommel inclination were fixed parameters. Variation in these parameters would undoubtedly affect absolute test values at a given feedrate and trommel rotational speed. However, it is believed that the general relationships pointed out in this section would hold true over the ranges in which the hole size, hole configuration, and trommel inclination would vary in normal operations.

- Trommel screening efficiency decreases as feedrate increases. Although there is considerable data variability, the trend is generally linear. Screening efficiencies as bigh as $90 \%$ and above can be achieved at very low feedrates, and generally screening efficiency is greater than $80 \%$ at a feedrate less than $9 \mathrm{Mg} / \mathrm{h}$ for the screen tested in this work.

- Screening efficiency generally increases with rotational speed (to an upper limit) although the rotational speed effect is not pronounced at lower feedrates because of the lifter effect. The Baltimore County trommel has lifters which tend to raise material to approximately the same height irrespective of rotational speed.

- The trommel removes both moisture and ash because the undersize material is higher in these constituents. Moisture content and ash content removal decreases with increasing feedrate because of the decreased screening efficiency and consequently the greater carry-over of the fines with the oversize material.

- Heating value improvement decreases with increasing feedrate because of decreased ash removal. However, heating value is increased at the expense of losing heat energy with the undersize material. Energy recovery in terms of the energy in the oversize recovered from what is available in the feed increases with feedrate because screening efficiency is lower and less heat energy is removed with the undersize.

- Organic content correlates with heating value and, therefore, to feedrate. Since few plants have the capability to measure heating value, organic content may be used as a field measure for evaluation of screening performance where a fuel product is being produced. 
- Seasonal variations were present in the trommel infeed. During the summer test period, the infeed had the smallest particle size and the highest moisture content due to the larger percentage of lawn and garden waste in the MSW. Data variability was large enough that no conclusions could be drawn concerning trommel performance versus season of the year.

- Under proper operating conditions (when the feedrate is not too high) the trommel in most cases removes noncombustibles sufficiently to reduce ash content and to increase heating value to meet the dry basis fuel specification of $15,120 \mathrm{~kJ} / \mathrm{kg}(6,500$. Btu/lb) and $15 \%$ ash.

- Trommel costs including capital depreciation, operation and maintenance, materials and labor, power, and all overhead costs were $\$ 17,809$ for the year. The trommel was operated for $2,906 \mathrm{~h}$, yielding an average cost of $\$ 6.13 / \mathrm{h}$. Because the pellet system average capacity was much less than the trommel capac1ly, a dullars per hour value is a better ratio for comparison.

- Except at very low flow rates the trommel has a net positive economic impact when calculated on the basis of the dollar value of the heating value increase less trommel costs. An optimum feedrate is not clearly defined, but keeping feedrates within a 7 to $13 \mathrm{Mg} / \mathrm{h}$ range insures optimum economic contribution, which averages $\$ 6.26 / \mathrm{Mg}$ for this infeed range.

- Physically, the trommel can handle feedrates as high as $40 \mathrm{Mg} / \mathrm{h}$. The maximum tested was $46.6 \mathrm{Mg} / \mathrm{h}$ at $12 \mathrm{rpm}$. However, at the higher feedrates the trommel cends to acl wuit as a conveyor and less as a screen because of the increased bed depth. Feedrates are dependent on the desired objective. To maximize encrgy recuvery, high fccdrates should be lised. To maximize screening efficiency, low feedrates should be used. Plant experience has been to operate within a range of 7 to $13 \mathrm{Mg} / \mathrm{h}$. Test results tend to support this experzence. The plaul ibjective io to moet fuel specifications. While limiting feedrates will not necessarily guarantee those fuel specifications are met, uperating at no more than $13 \mathrm{Mg} / \mathrm{h}$ will incrcase the probability of meeting them.

\subsection{RECOMENDATIONS}

The Baltimure trommel design is adequate to mcet the ash removal needs of the dRDF fuel specification. However, the trommel does so by removing a significant amount of undersize material. Within the normal operating range of 7 to $13 \mathrm{Mg} / \mathrm{h}$, the undersize averaged $46 \%$ by weight of the infeed. Smaller screen hole sizes could probably be used to reduce the amount of undersize, and still meet the $15 \% \mathrm{dry}$ basis ash fuel specification. The optimum hole size, however, cannot be determined from the data in hand. Alternatively, it is recommended that consideration be given to further processing of the trommel undersize to recover usable material. 


\subsection{SITE AND FACILITIES DESCRIPTION}

\subsection{GENERAL FACILITY DESCRIPTION}

The address of the Baltimore County MSW processing plant is 10320 York Road, Cockeysville, Maryland 21031. The plant telephone number is (301) 628-1130 or 1135, and the plant manager is Mr. Ken Cramer. The plant is operated by Teledyne National for Baltimore County in conjunction with the Maryland Environmental Service. The plant receives MSW from the surrounding area which is then processed into refuse derived fuel (RDF) or densified refuse derived fuel (dRDF). Figure 3.1 is a schematic diagram of the plant.

Figure 3.2 is a general view of the facility as seen from the west and south. The large door openings give access to the storage pits where MSW is received. The rectangular structure at the north end of the building; with the piping connected to it, is the baghouse for the dust collection system. The open structure on the east side of the building is the magnetic separator system. The first building south of the main building houses the maintenance and parts. area.

The plot plan for the complete facility is shown in Figure 3.3. The operating part of the facility utilizes $7,580 \mathrm{~m}^{2}$. Figure 3.4 of the MSW processing facility and Figure 3.5 of the RDF processing facility are pictorial flow diagrams.

Incoming commercial loads of MSW are weighed before they go to the pit area. Citizens bringing in small quantities of waste deposit it in opentopped trailers at the facility entrance. When the trailers are full, they are weighed at the scales before being dumped into the holding pit or the push pits.

The pit area is made up of a holding pit with two movable bridges giving access to the four push pits. The material dumped into the holding pit is later transferred into the push pits by a grappling crane which can travel over the entire pit area.

Each line operator sits in an enclosure built into the wall that divides the storage area and the shredder room. From this vantage point the operator can control the flow of material into each shredder. Small grapples are used to mix the material in the push pits before feeding it into the shredder.

The two processing lines are identical through the magnetic separator system; therefore, in the following description the conveyor numbers for the first processing line are used. 


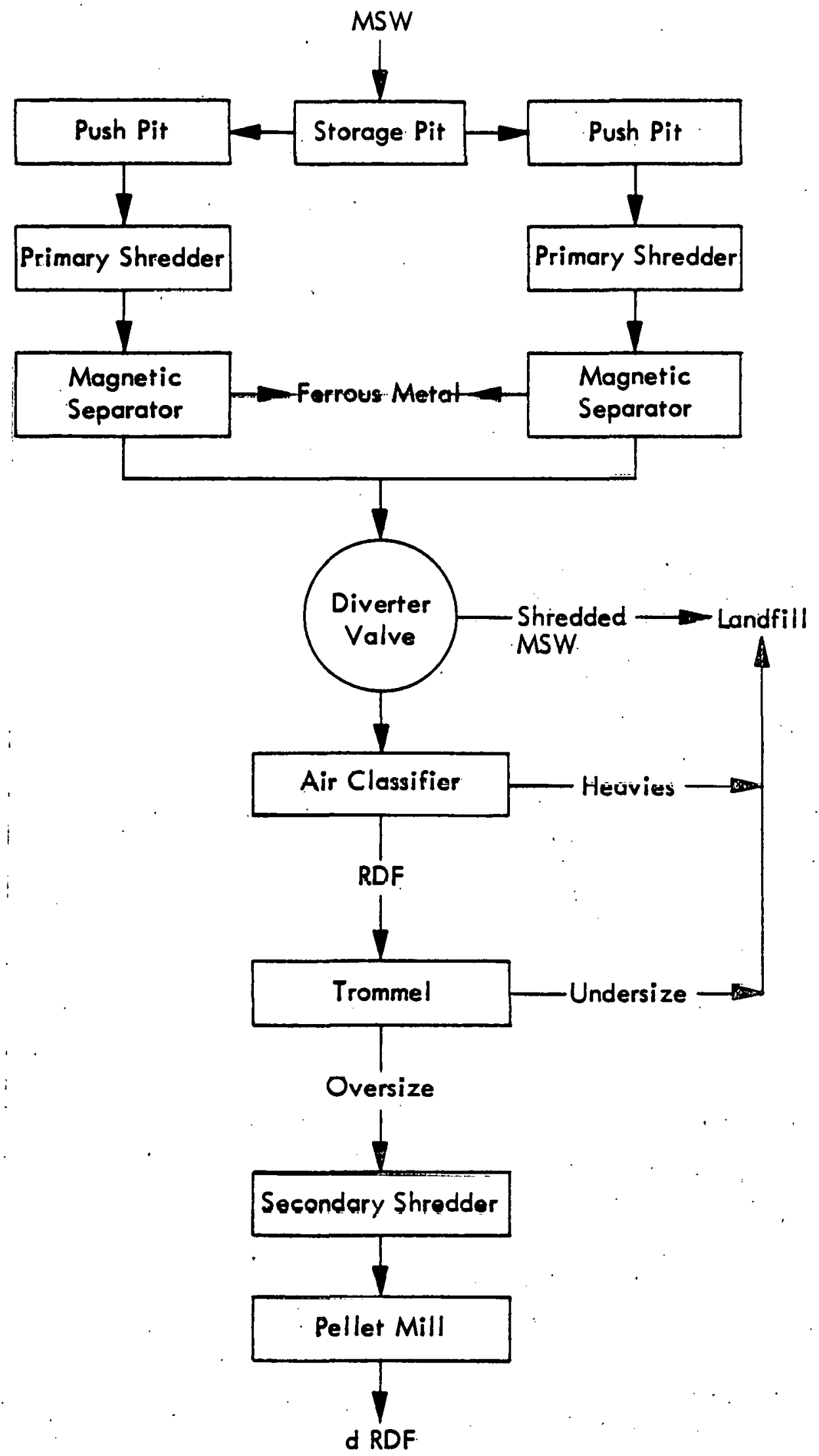

Figure 3.1. Schematic Diagram of the Baltimore County Solld Waste Processing Facility. 

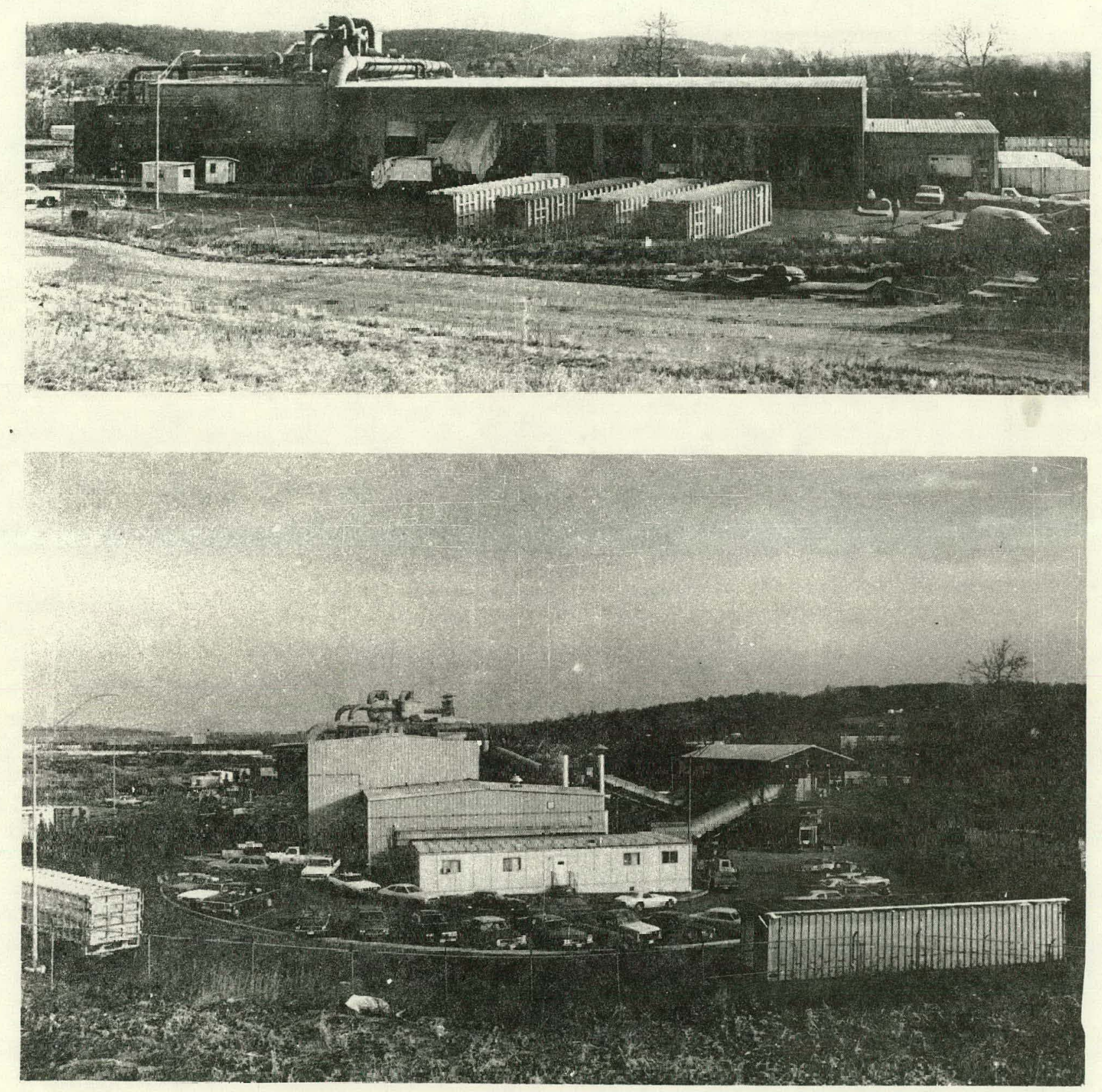

Figure 3.2. General View of the Baltimore County Solid Waste Processing Facility. 


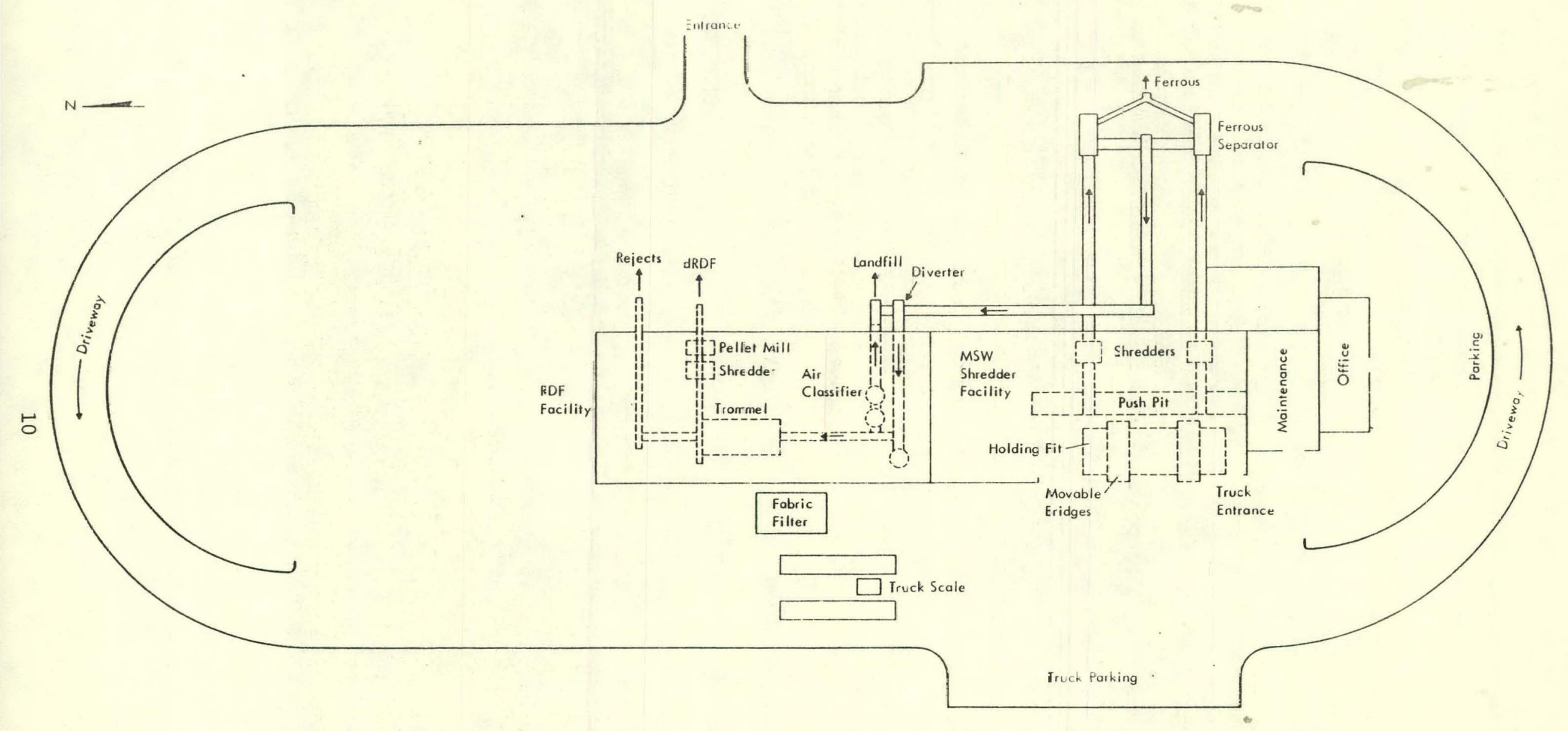

Figure 3.3. Plot Plan - Baltimore County Solid Waste Frocessing Plant. 


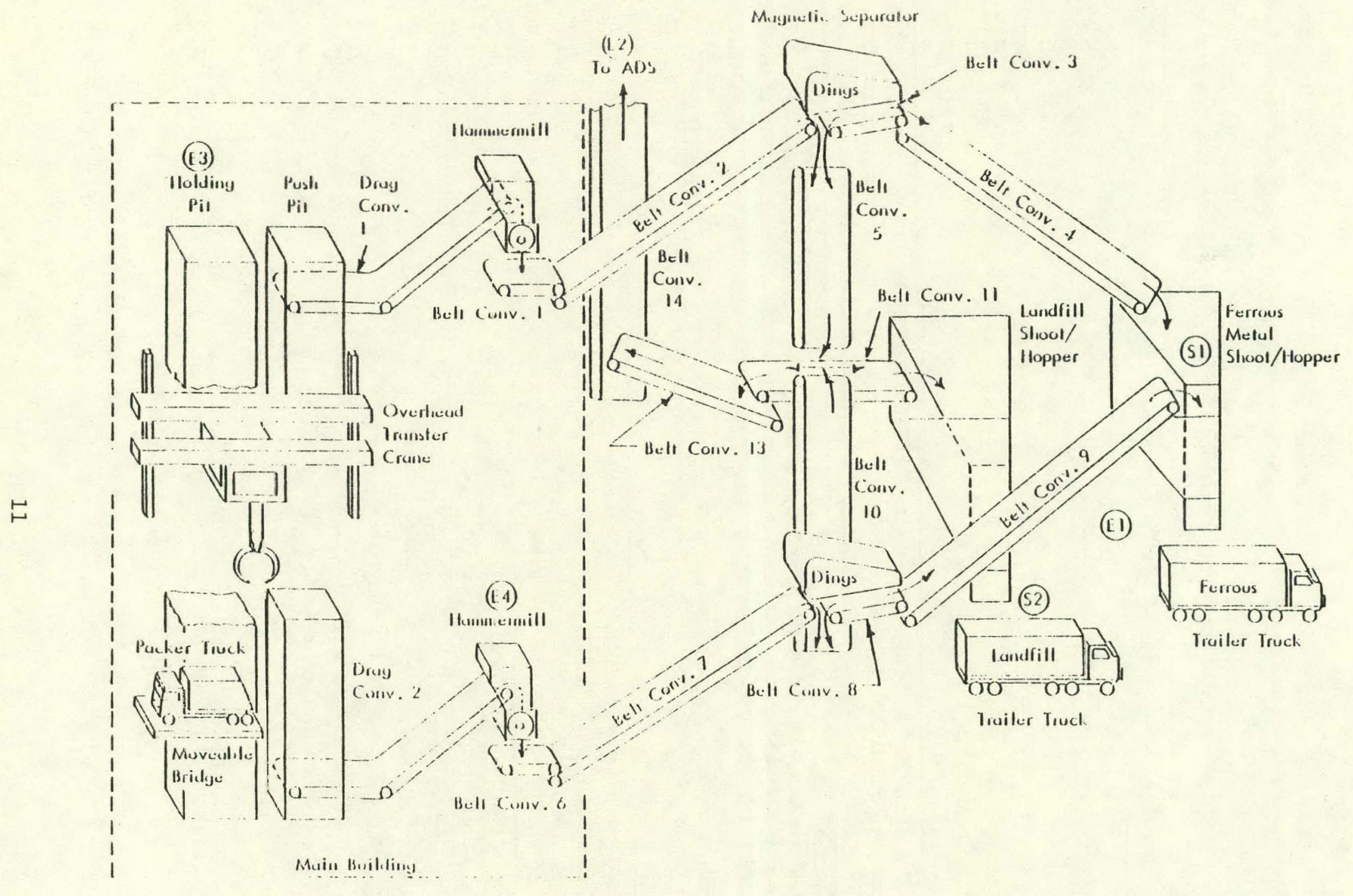

Figure 3.4. Flow Diagram for Receiving Through Ferrous Recovery, Baltimore County. 


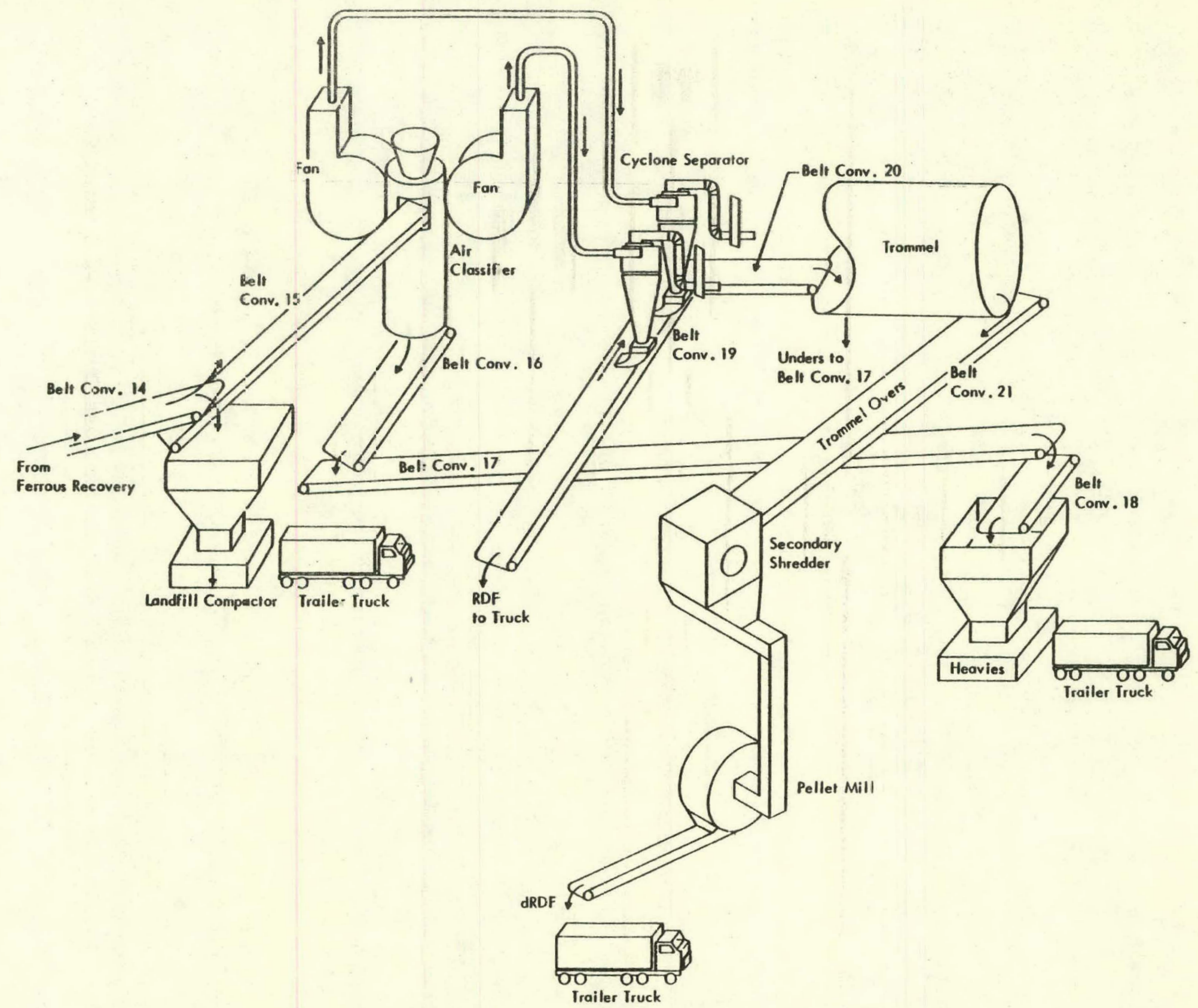

Figure 3.5. Flow Diagram of RDF Processing, Baltimore County. 
The material is transported from the push pits to the shredder inputs by drag conveyor 2. The shredders (Figure 3.6) are Tracor Marksman Model $860,45.5 \mathrm{Mg} / \mathrm{h}(50 \mathrm{ton} / \mathrm{h})$ units driven by $1,000 \mathrm{hp}$, Toshiba reversible electric motors directly coupled to the rotor shaft. The shredders are equipped with a Fenwal explosion suppression system.

The shredded MSW is carried to the elevated magnetic separation system (Figure 3.7) on belt conveyor 7 . The nonmagnetic material drops onto belt conveyor 8 and eventually into the RDF processing building.

The recovered magnetic material is transported to the output chute by belt conveyor 9 . This chute collects the material from both magnetic separators and empties it into an open-topped trailer. Figure 3.8 is a view down belt conveyor 4, which is carrying a typical load of ferrous metal. Belt conveyor 10 carries the rejected material to belt conveyor 11 , which combines the material from both streams for further processing. Belt conveyor 11 is reversible to allow bypassing the processing building by feeding into the open-topped trailer shown in Figure 3.9. Belt conveyor 11 normally feeds the short horizontal belt conveyor 12 . The material is then transported via belt conveyors 13 and 14 into the processing building.

At the intersection of belt conveyors 14 and 15 , there is a poweroperated diverted blade (Figure 3.10) which directs the flow onto belt 15 or into the compactor hopper.

The RDF processing is monitored and controlled at the panel shown in Figure 3.11. The TV screens are used to monitor six critical locations and to provide visual confirmation of parameters and safety.

Belt conveyor 15 empties into the air classifier, which uses two fans to pull off the lighter (mostly combustible) part of the shredded MSW. The light material is then collected in two cyclone separators and fed through air locks onto belt conveyor 19 (Figure 3.12). Belt conveyor 20 carries this material into the trommel where the fine material (mostly glass and dirt) is removed.

The heavier part of the infeed to the air classifier drops out of the bottom onto belt conveyor 16 , then to 17 and 18 , and then into a truck for hauling to the landfill.

Since the air classifier operation has the greatest effect on the trommel infeed composition, the air classifier is shown in detail in Figures 3.13 and 3.14 .

Figure 3.15 shows the layout of the RDF $34.1 \times 22.2 \mathrm{~m}$ (112 x $73 \mathrm{ft}$ ) processing plant, and Table 3.1 is a list of the major equipment in the RDF building. 


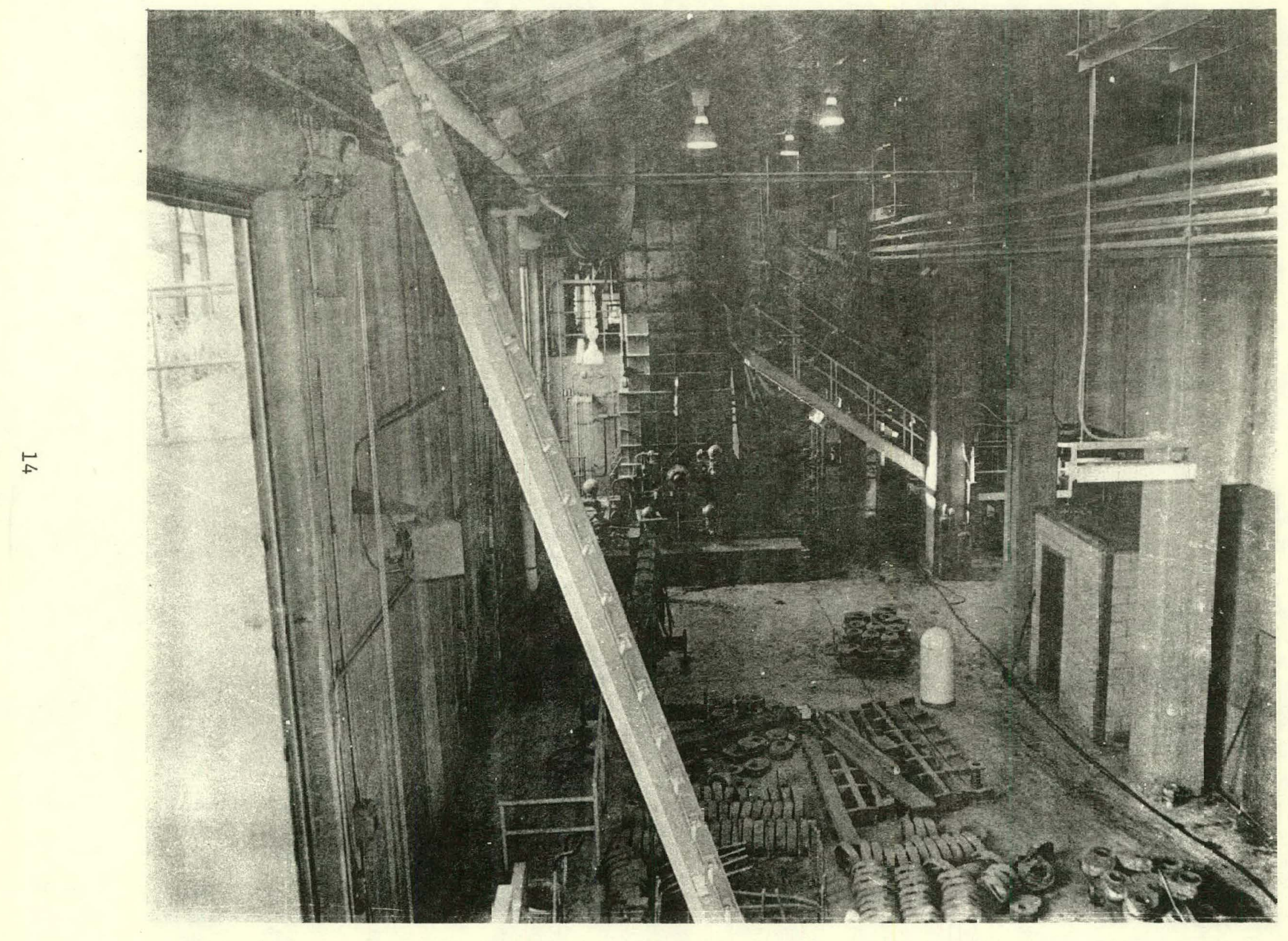

Figure 3.6. Background: Primary Shredder and Inclined Drag Conveyar to Shredder, Foreground: Grate Bars and Hammers, Baltimore County. 


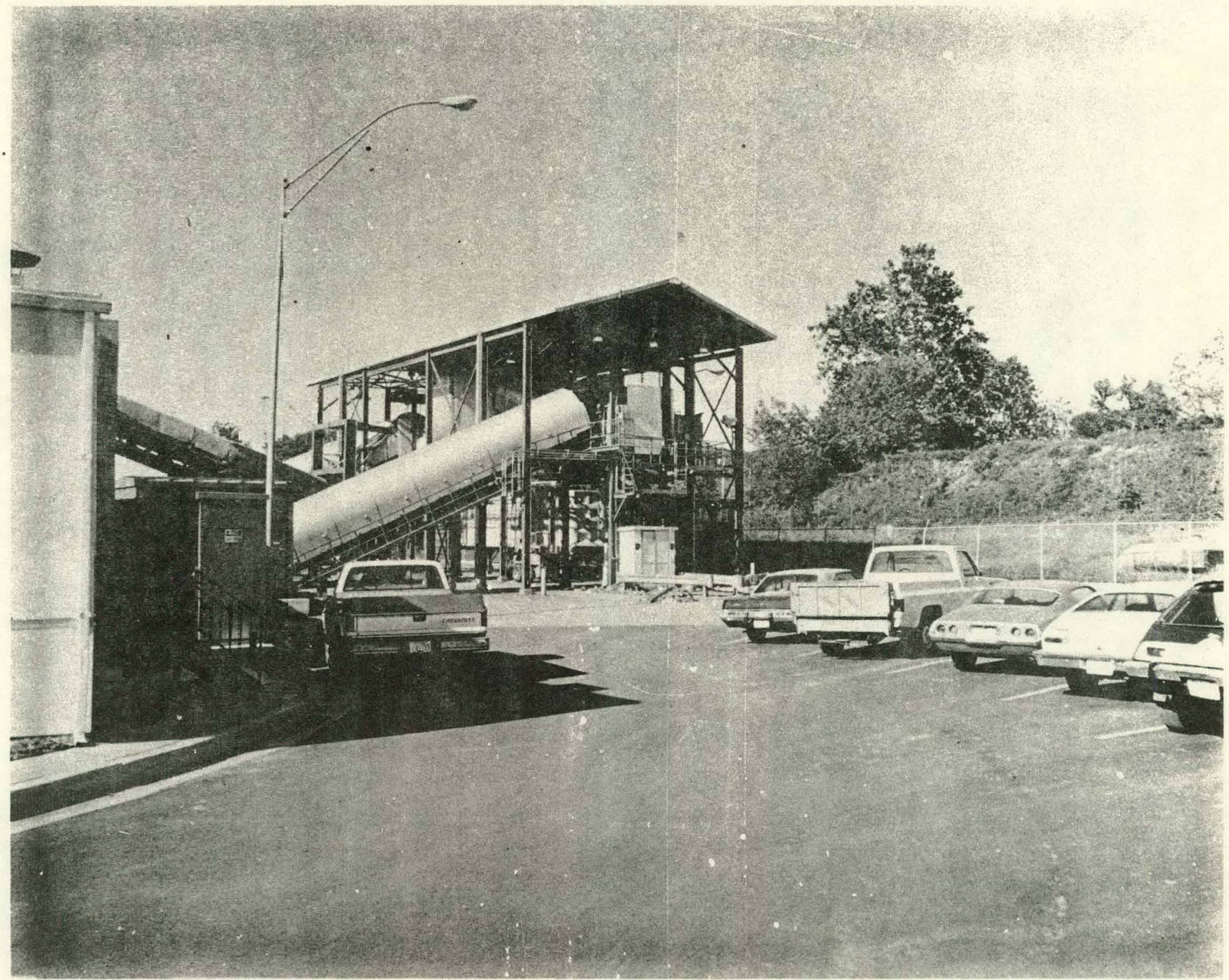

Figure 3.7. Magnetic Separator System, Baltimore County. 


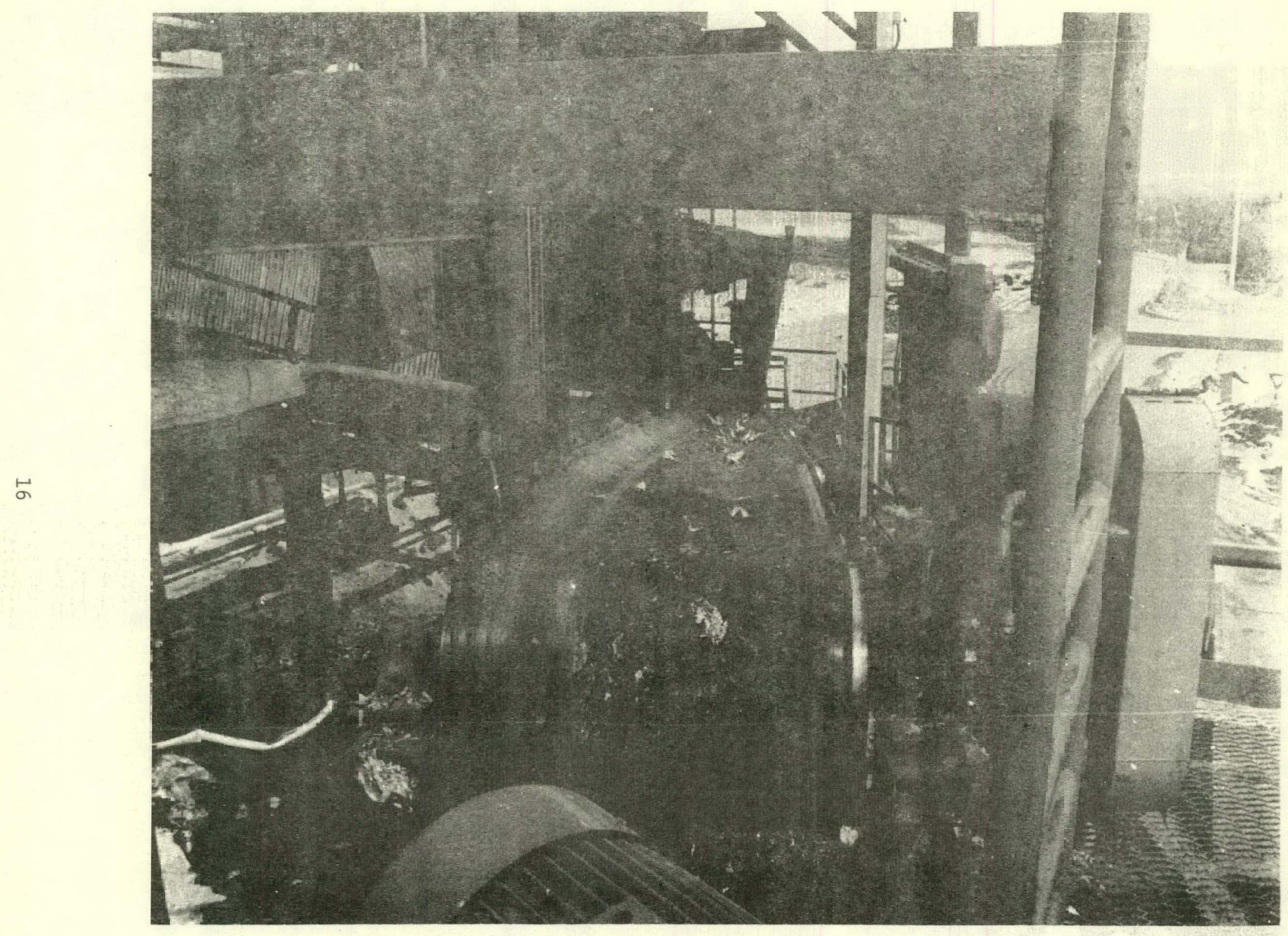

Ffgure 3.8. Output Belt, Mageetic Separator, Baltimore County. 


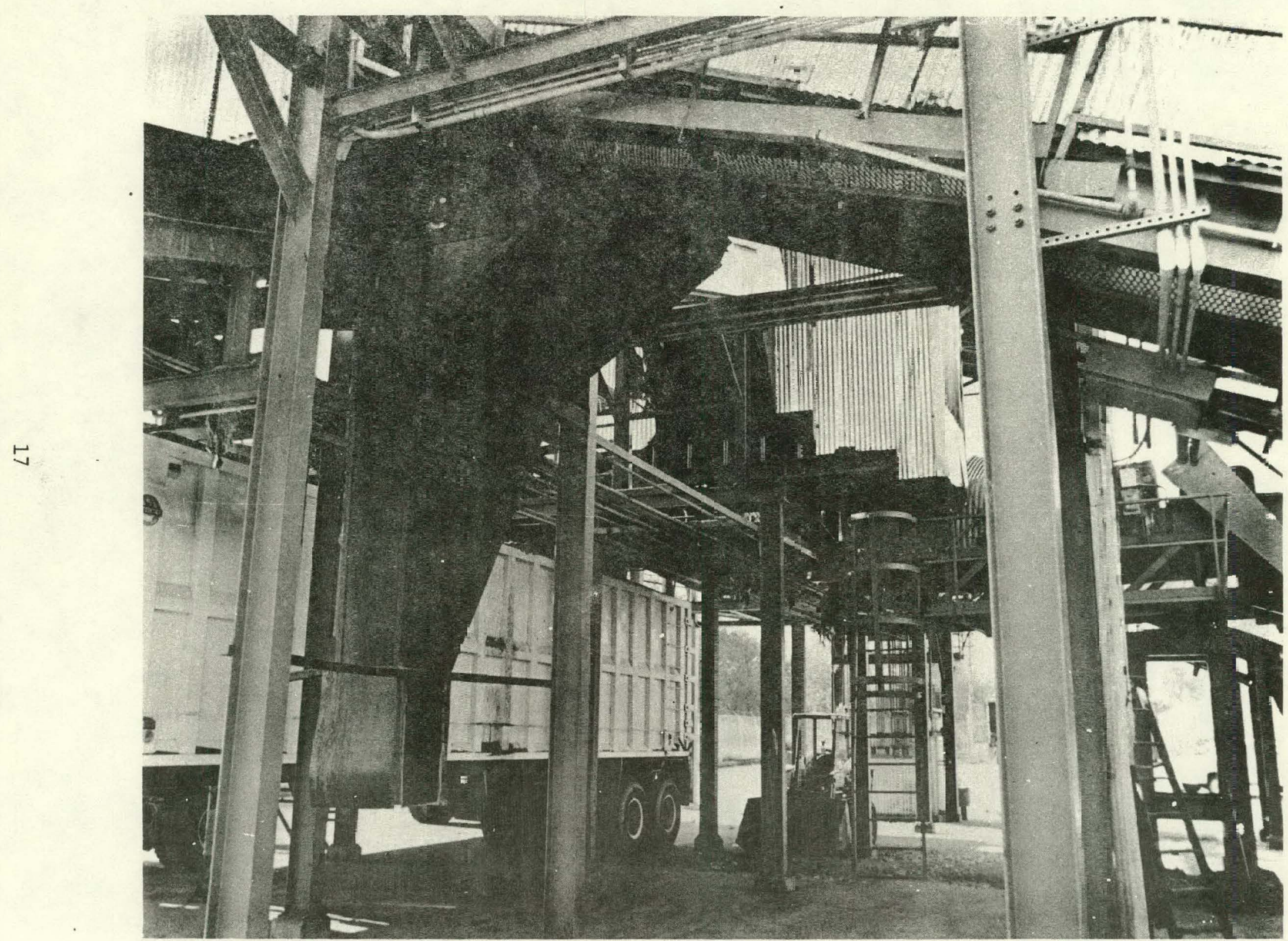

Figure 3.9. Output Chute for Rejects, Ealtimore County. 


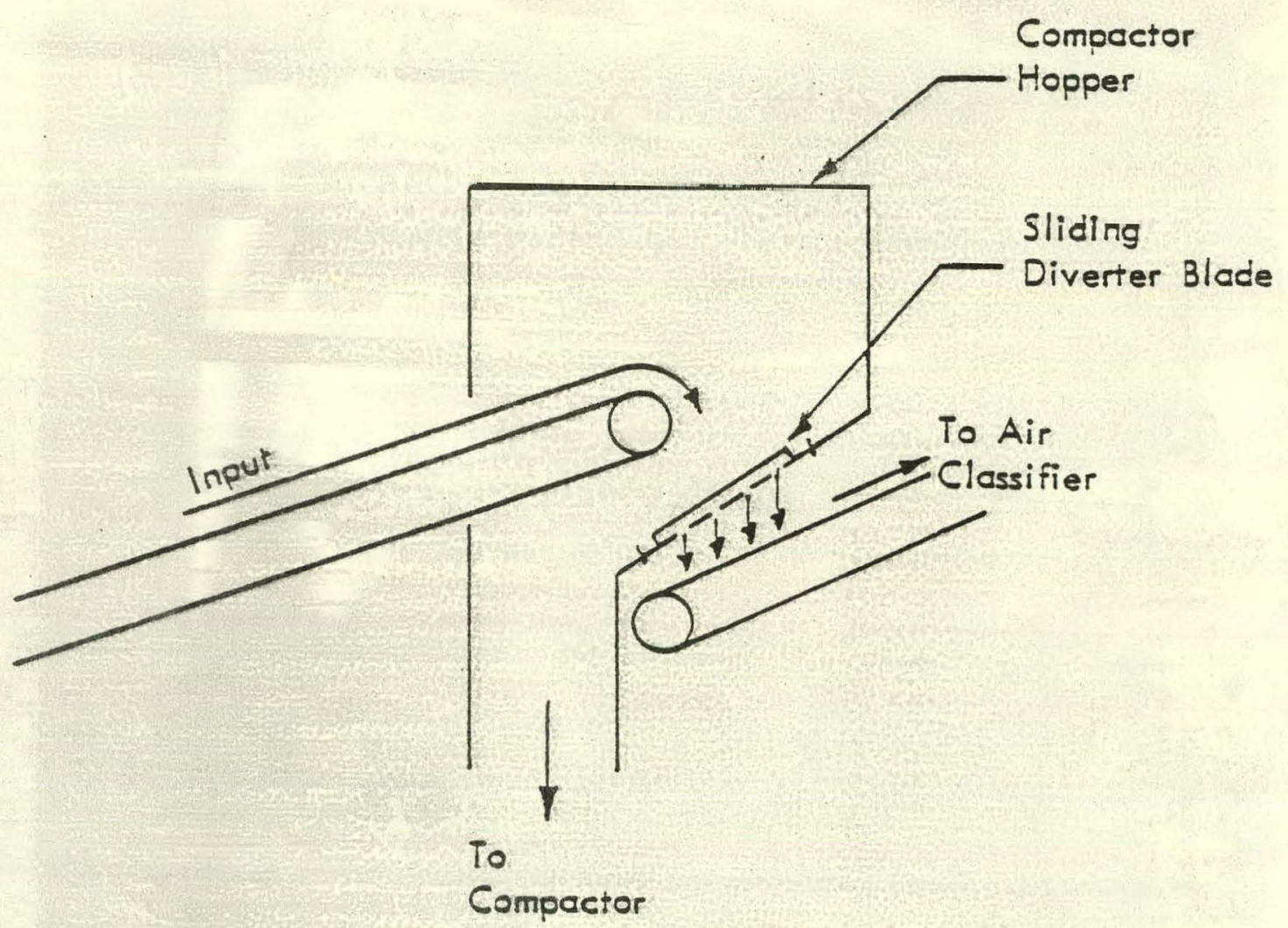

Eigure 3.10. Diverter Blade System, Baltimore County. 


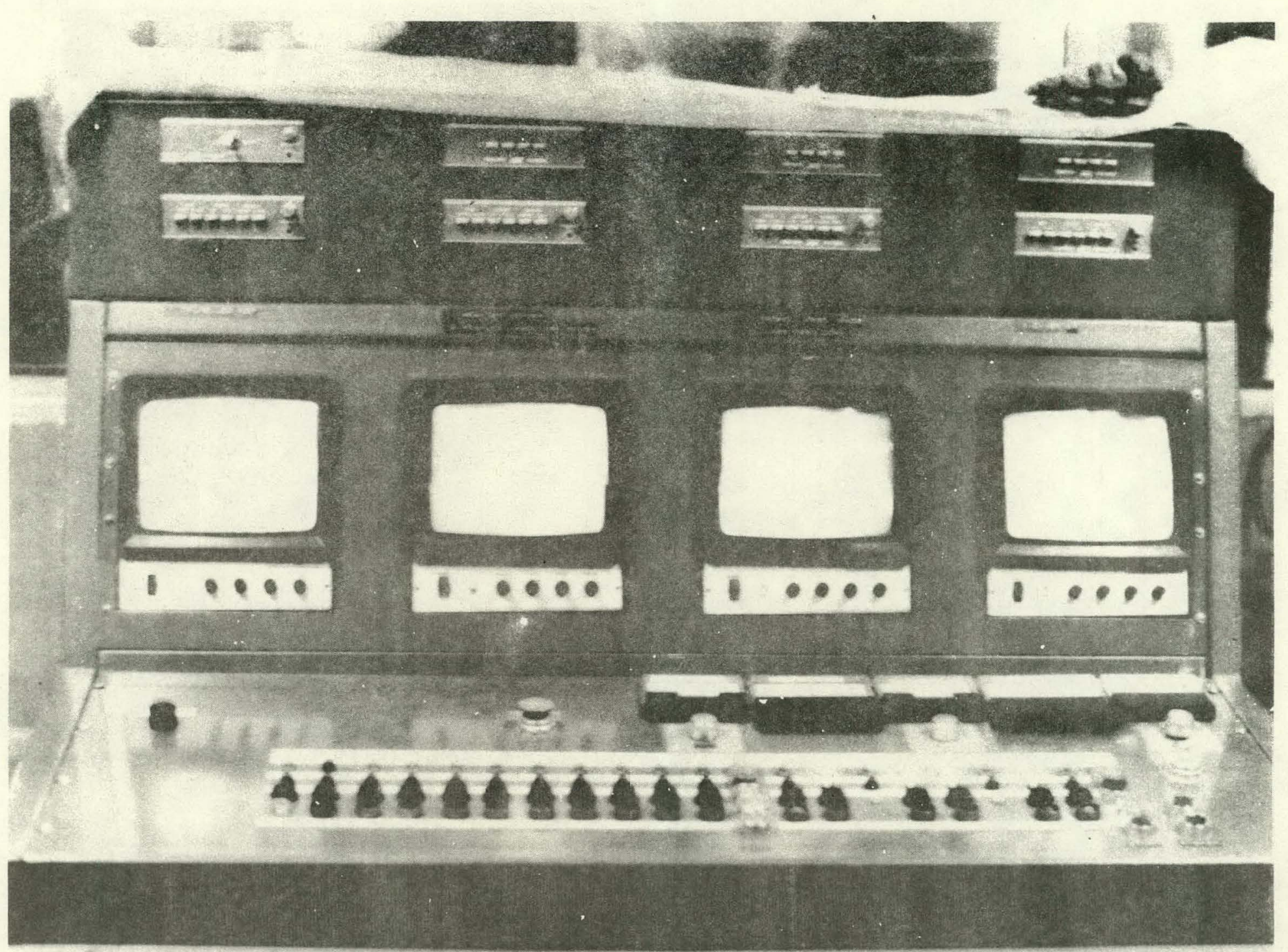

P.

Figure 3.11. RDF Processing Line Control Pane1, Baltimore County. 


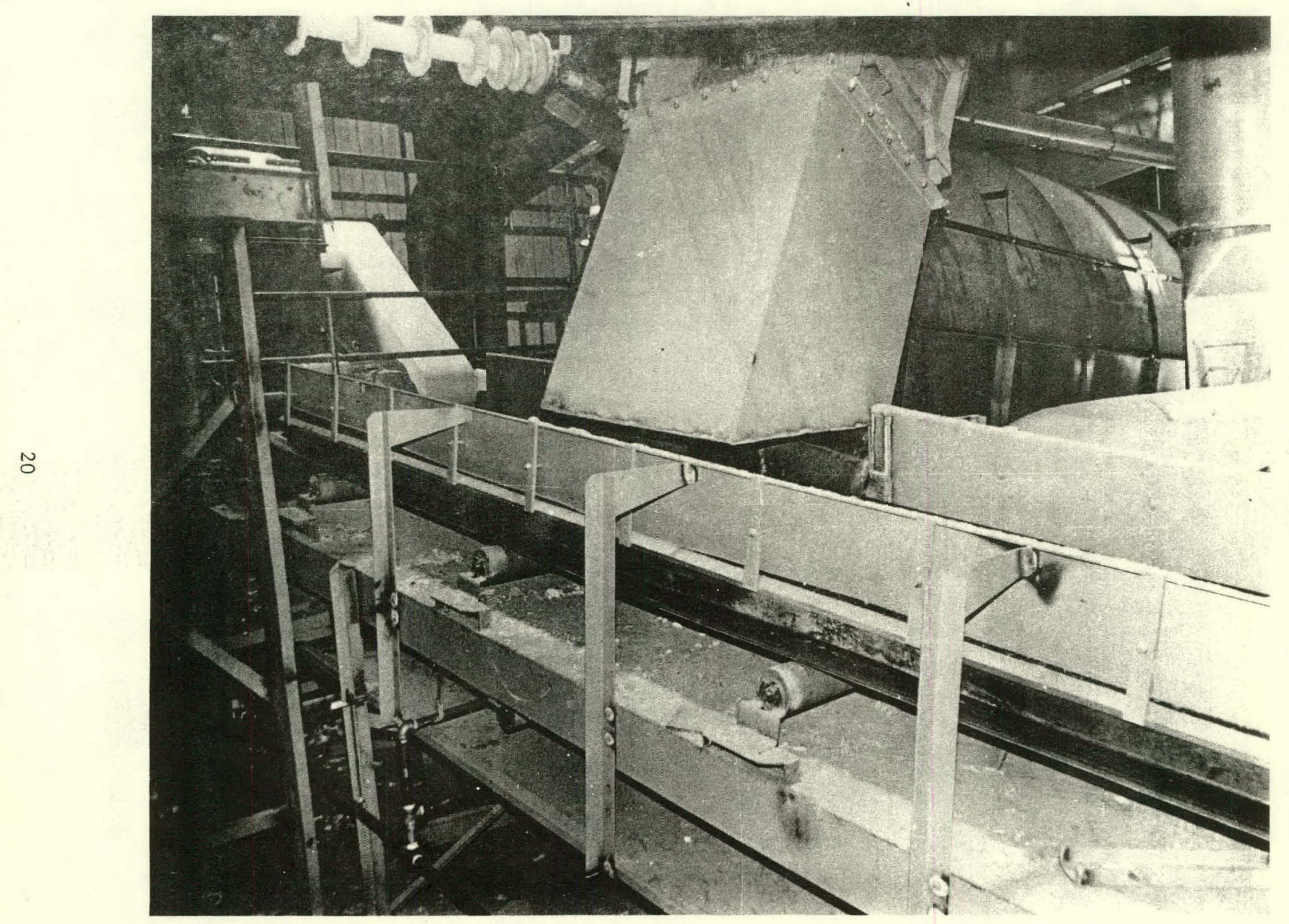

Figure 3.12. Belt Conveyor 19 - Trommel in Background, Ealtimore County. 


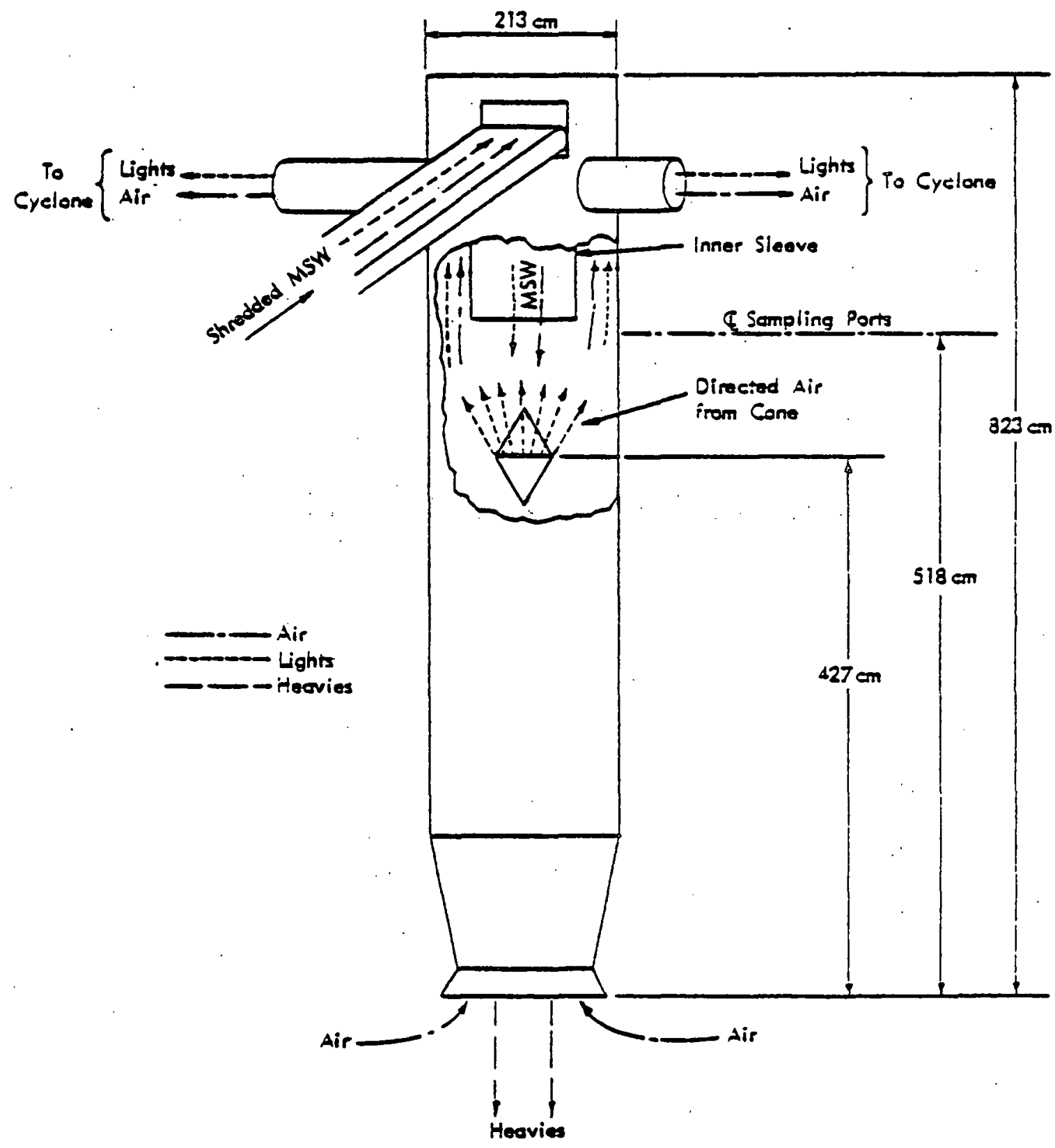

Figure 3.13. Air Classifier Details, Baltimore County. 


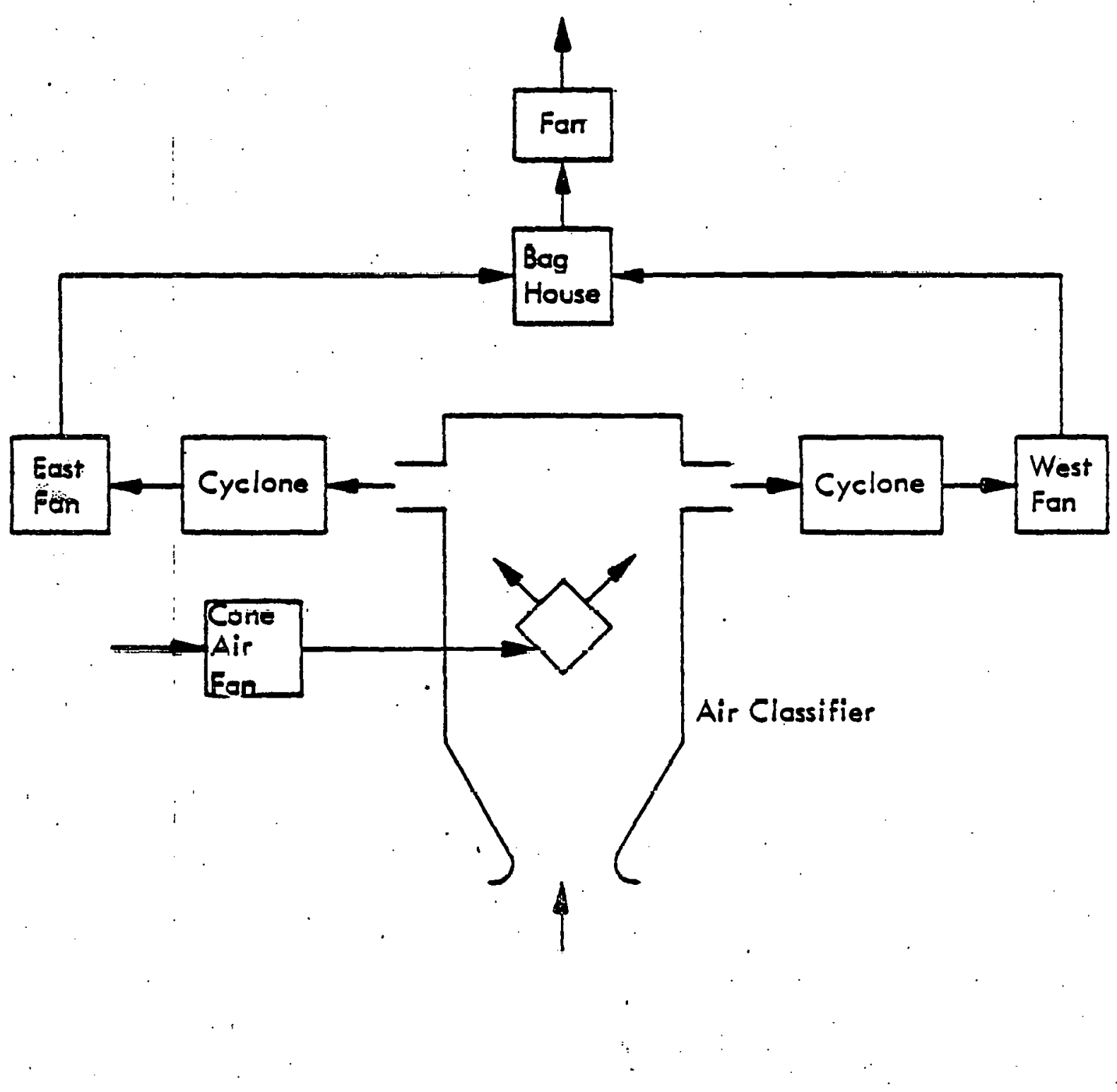

Flgure 3.14. Alr Classifier Alrflow Dlagram, Baltimore County. 


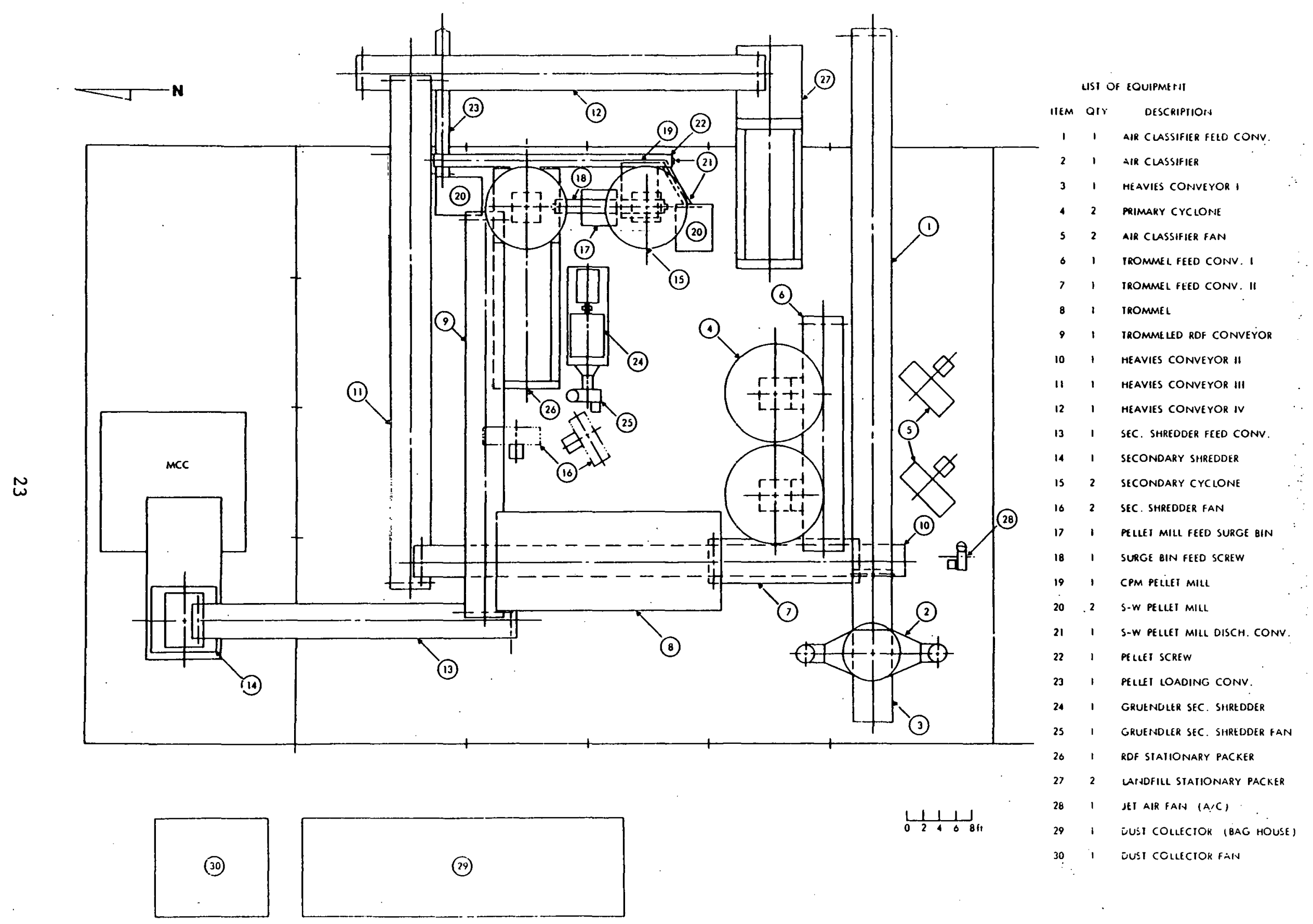

Figure 3.15. RDF Plant Layout, Baltimore County. 


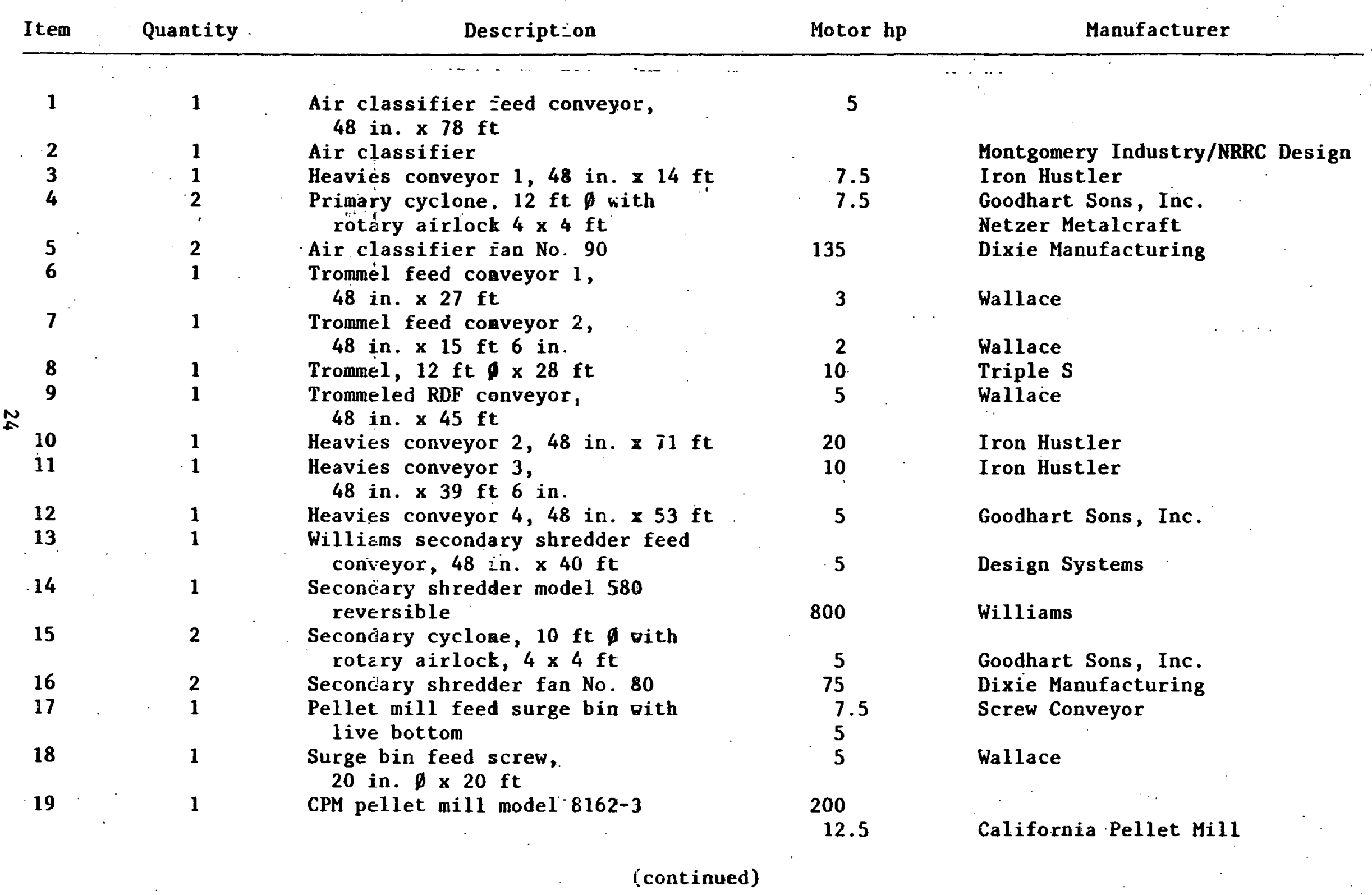


TABLE 3.1 (continued)

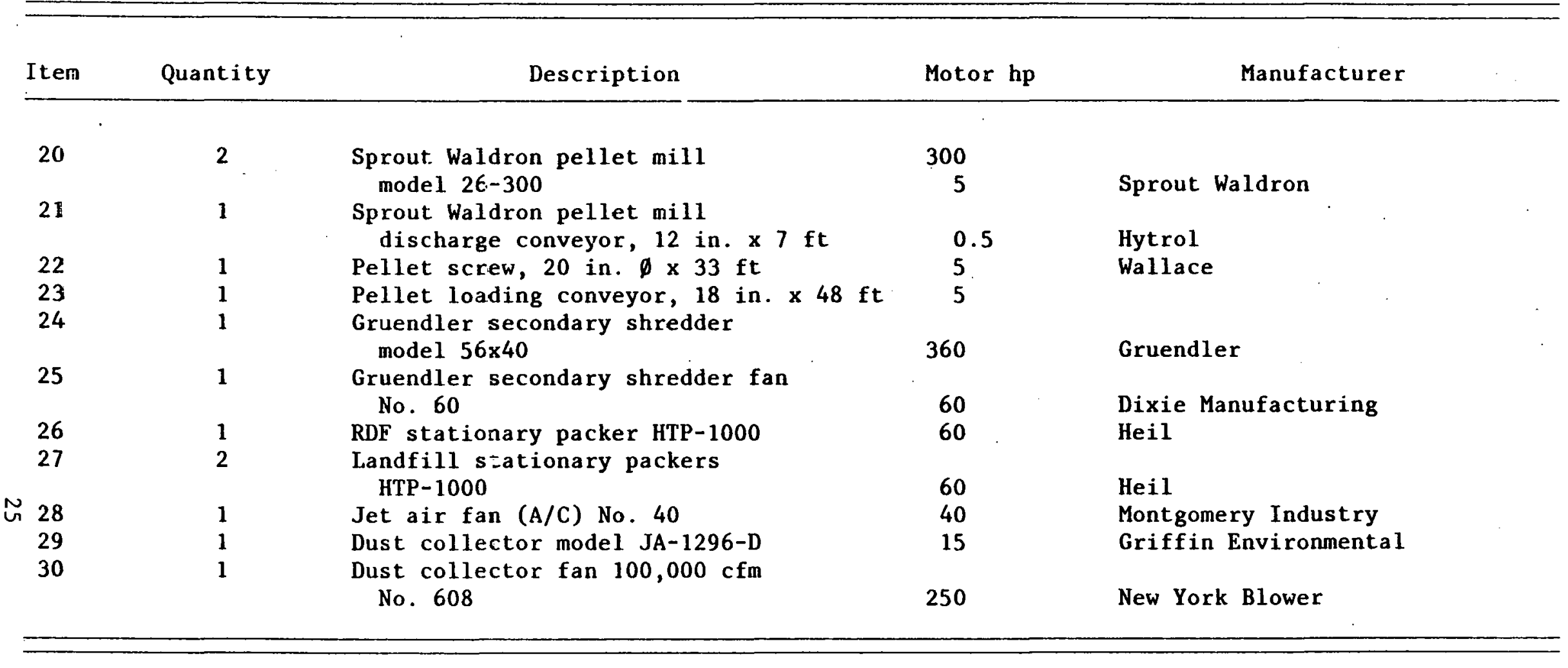




\subsection{TROMME DESCRIPTION}

The purpose of the Baltimore trommel is to "clean up" air classified $\mathrm{RDF}$ by removing fine material that is composed largely of small pieces of glass, metal, stones, dirt, sand (i.e., grit). Sixteen tests of the Baltimore air classifier ${ }^{1}$ showed that 14 mesh grit in the air classifier lights, which is the trommel screen infeed, ranged from 14 to $32 \%$ with the average being $20 \%$. To reduce wear on the pellet mill, it is well to remove this material before secondary shredding and pelletizing:

Figure 3.16 lists the specifications of the Baltimore trommel. Figure 3.17 is a layout of the trommel showing the lifter distribution. This unit is a single function trommel; that is, the trommel has only one set of hole sizes and is used only to remove fines. Thus, there are only three material flow streams of interest.

- Infeed - Alr classified RDF

- Undersize - Reject material

- Oversize - Infeed to the secondary shredder and pellet mill

Figure 3.18 is a pictorial view of the trommel showing the infeed and output conveyors. The trommel undersize falls directly onto belt conveyor 17, which was shown in Figure 3.5, and is mixed with the air classifier heavies. The trommel overs are conveyed by belt conveyor 21 to the pelletizing operation composed of the secondary shredder and pellet mill (Figure 3.19). Figure 3.20 of the interior of the empty trommel shows the lifter bars and some hole pluggage. Figure 3.21 shows the tumbling action of the material when the trommel is operating.

\subsection{TROMEL VARIABLES}

The trommel hole size is fixed at $31.8 \mathrm{~mm}(1-1 / 4 \mathrm{in.})$. The plant operators have considered using a smaller hole size, but the construction of the unit makes-it impossible to readily change hole sizes in the field. Thus, field tests were restricted to one hole size.

The slope of the trommel is fixed at 3 degrees, and because of the underneath trunnion drive, it is not possible to readily change the slope in the field. Therefore, field tests were restricted to one slope.

Due to the fact that the trommel drive motor is fitted with a variable pitch: V-belt sheave, rotational speed adjustments can be made in the fleld. The variable range is 6 to $12 \mathrm{rpm}$. The trommel diameter is $3.7 \mathrm{~m}$ (12 ft). The rpm range then corresponds to a circumferential speed of 69 to $138 \mathrm{~m} / \mathrm{min}$ (226 to $452 \mathrm{ft} / \mathrm{min}$ ). 


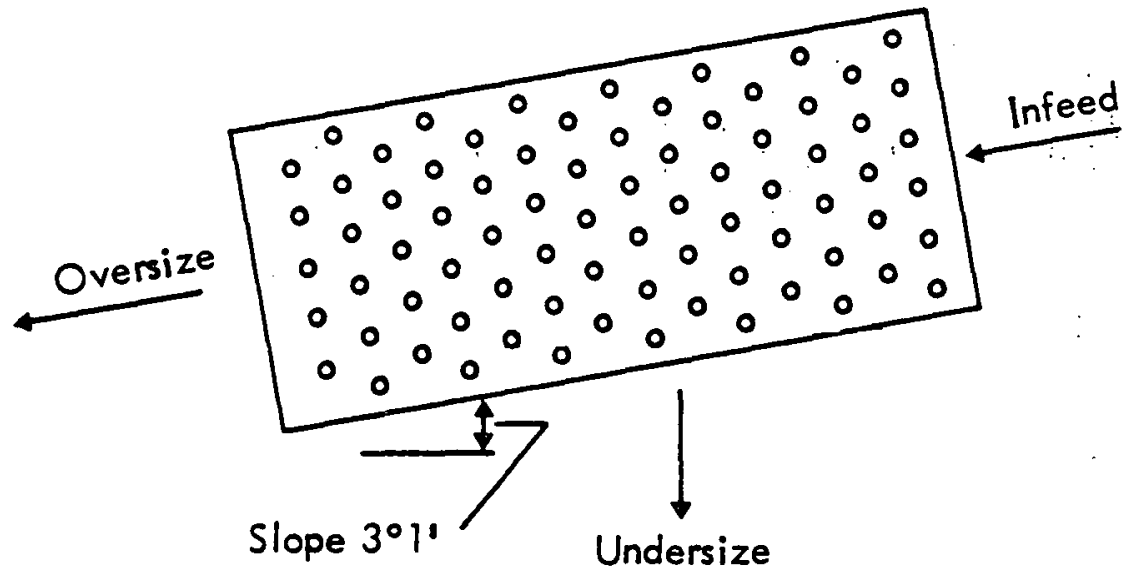

\section{SPECIFICATIONS}

Size

Total Length: $\quad 8.0(26.3 \mathrm{Ft}$.

Perforated Length: $\quad 7.4 \mathrm{~m}(24.3 \mathrm{ft})$

Diameter: $\quad 3.7 \mathrm{~m}(12 \mathrm{Ft}$.

Hole Diameter: $\quad 32 \mathrm{~mm}(1.25 \mathrm{ln}$.)

Effective Hole Area: $39.62 \mathrm{~m}\left(61,408 \mathrm{in} .{ }^{2}\right)$

Lifter Configuration: 9 Lifters, $3.05 \mathrm{~m}$ long $\times 30.5 \mathrm{~cm}$ high

( $10 \mathrm{Ft} . \times 12 \mathrm{ln}$.); parallel to $q_{1}$

equally spaced circumferentially, \& alternately placed at upper \& lower ends

Drive

Motor:

$7.5 \mathrm{~kW}(10 \mathrm{HP}), 230 / 460 \mathrm{~V}, 26.8 / 13.4 \mathrm{~A}$, $60 \mathrm{HZ}, 3$ phase

Rotational Speed: Variable 6 to 12 RPM

Description:

Drive motor has variable pitch $V$-belt sheave.

Trommel rotated by trunnions located underneath the trommel.

Figure 3.16. Speciflcations of Tromel Screen at Baltimore County. 


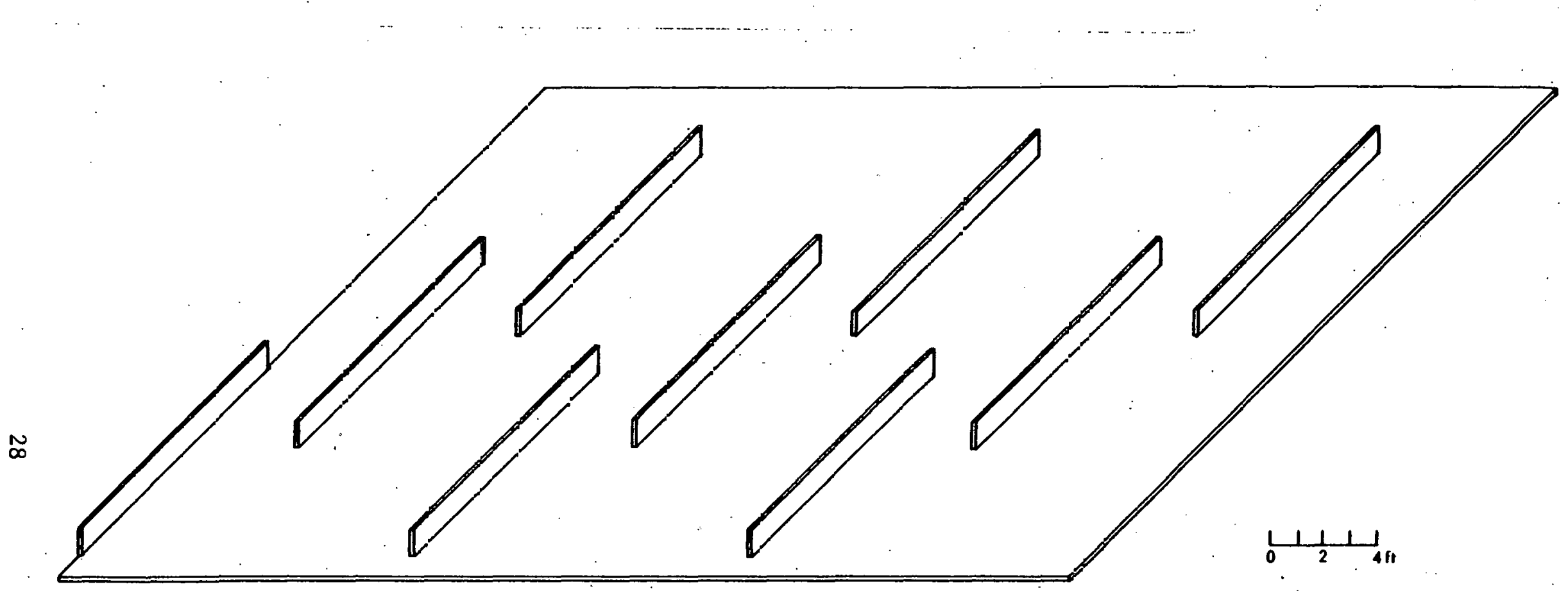

CIRCUMFERENCE OF TROMMEL LAD FLAT JO SHOW UTTER BAR ARRANGEMENT

Figure 3.17. Trowel Lifter Bar Arrangement, Baltimore County. 
ROTARY SCREEN SYSTEM

BALTIMORE COUNTY, MARYLAND

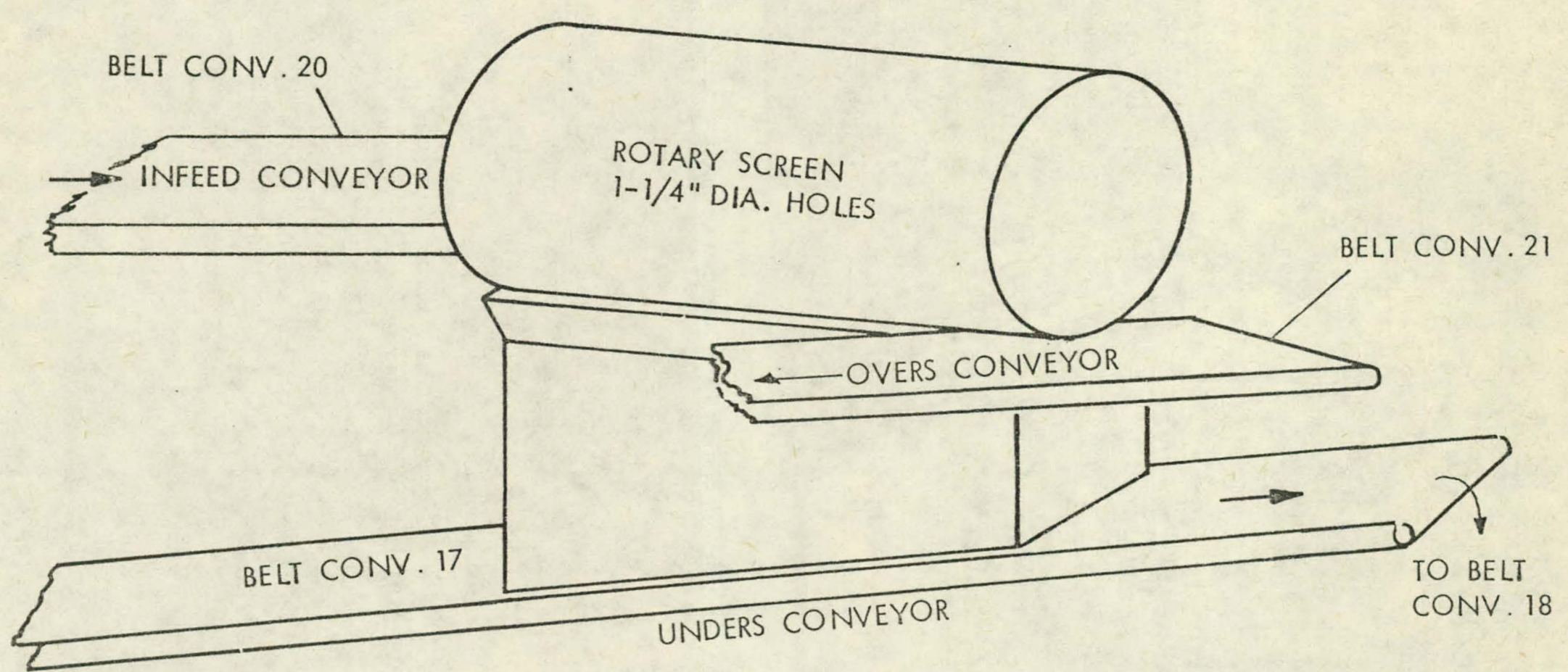

Figure 3.18. Trommel Flow Diagram, Baltimore County. 

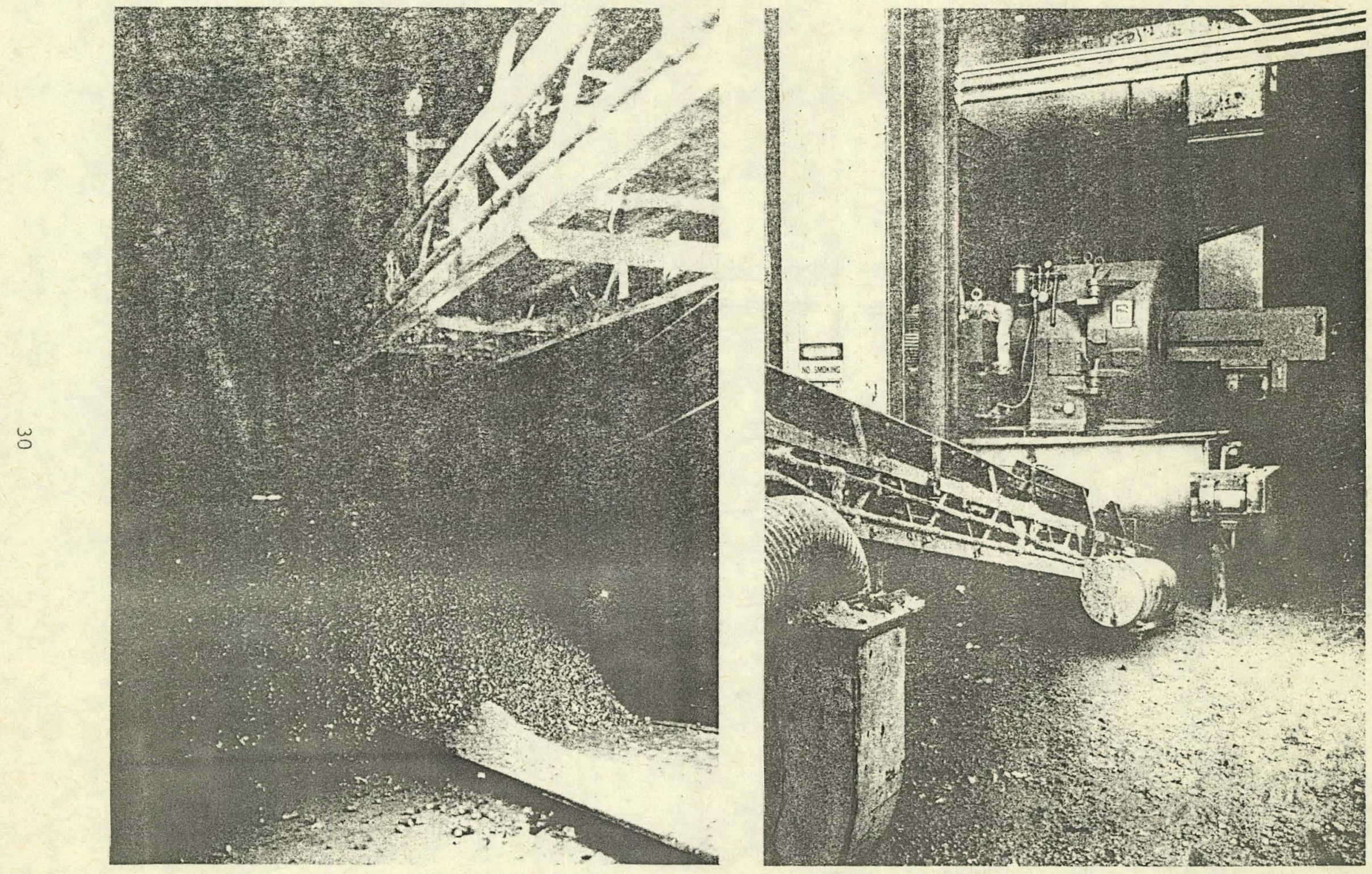

Figure 3.19. Pellet Mill and Trailer Being Loaded with Pellets, Baltimore County. 


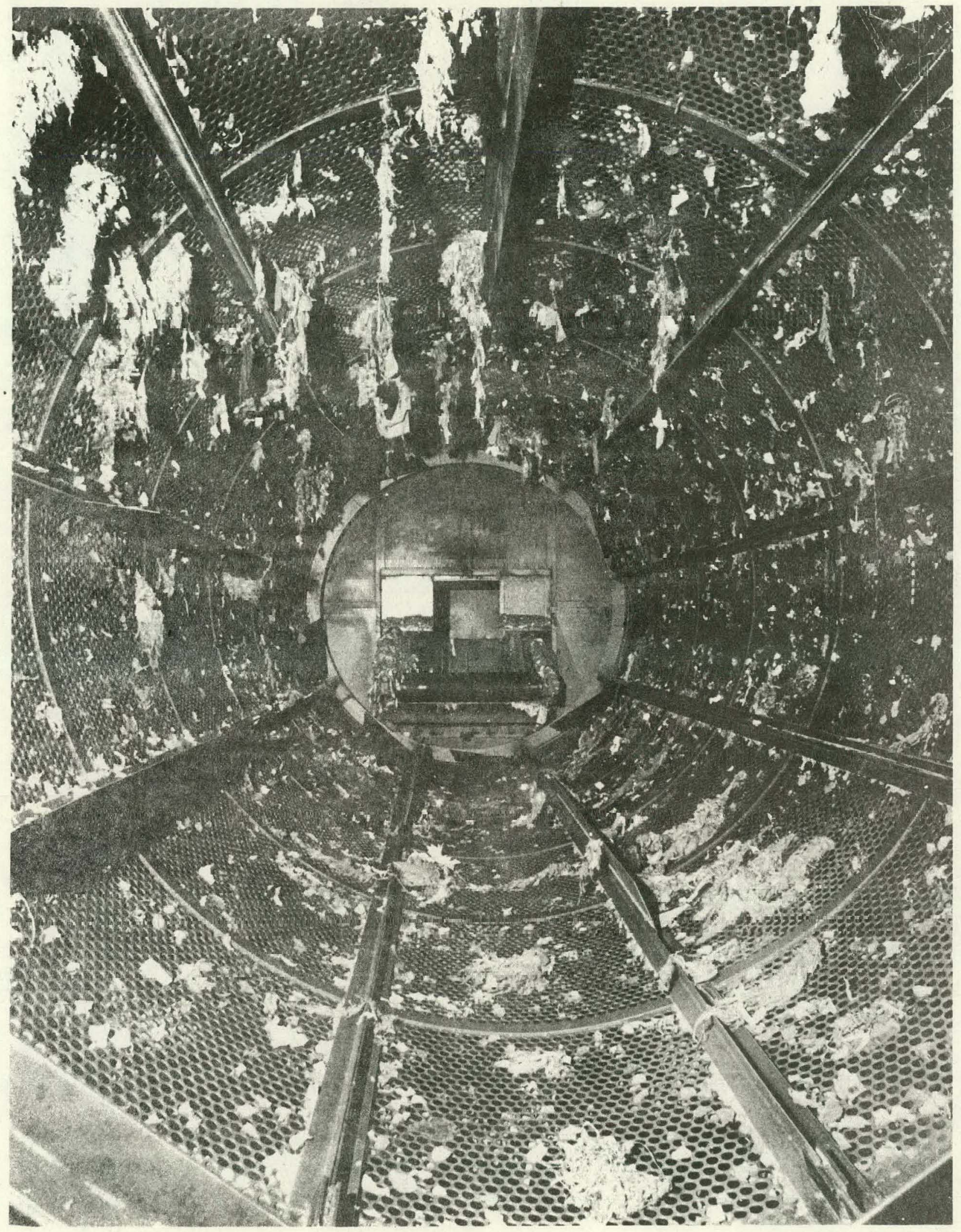

Figure 3.2n. Tnterior of Trommel, Baltimore County. 


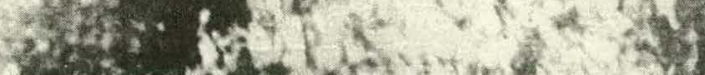

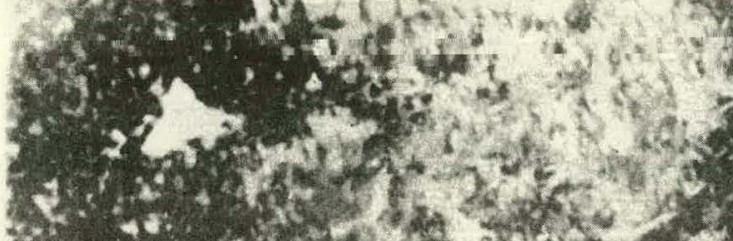

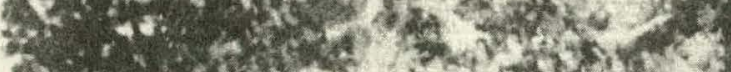

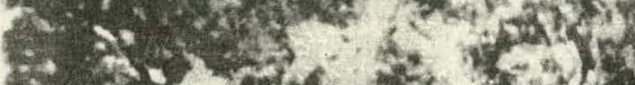

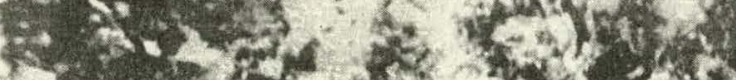

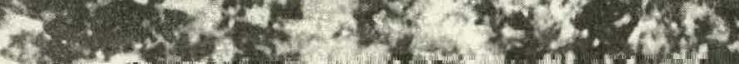

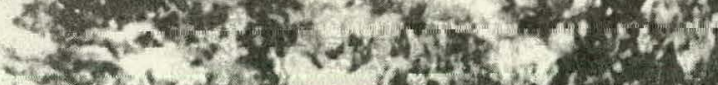

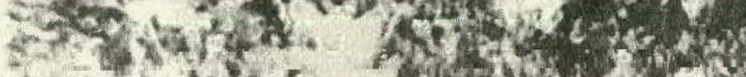

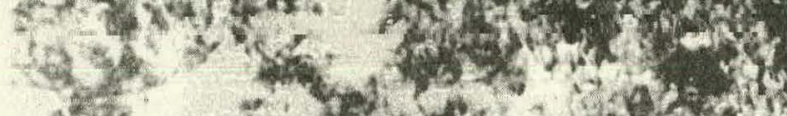

(2)

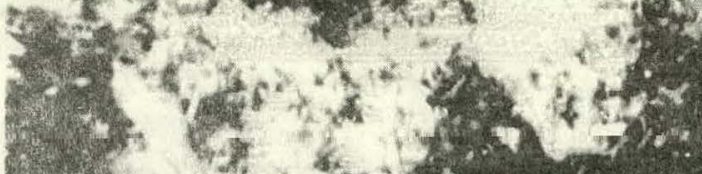

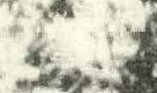

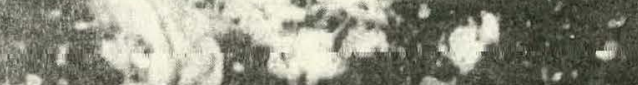

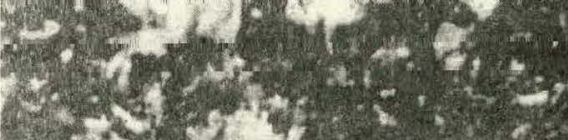

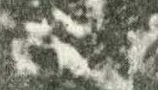

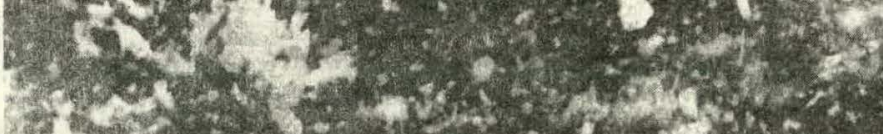

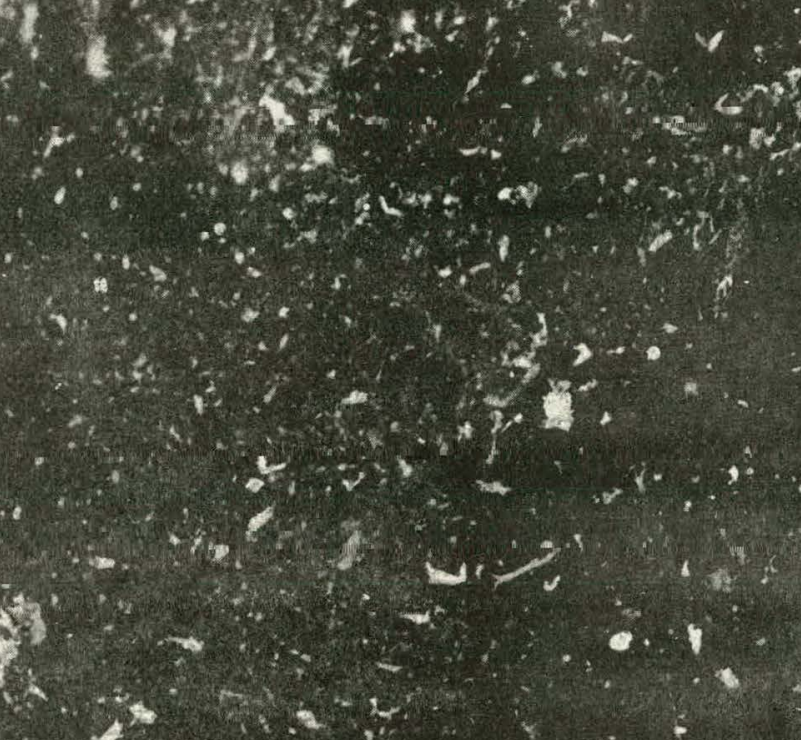

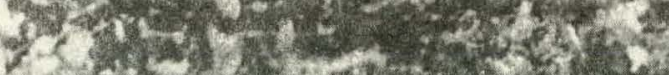

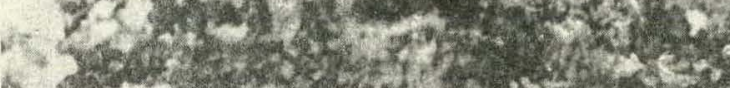

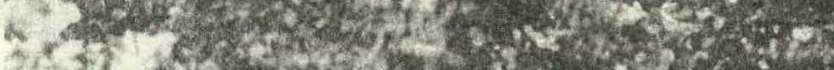

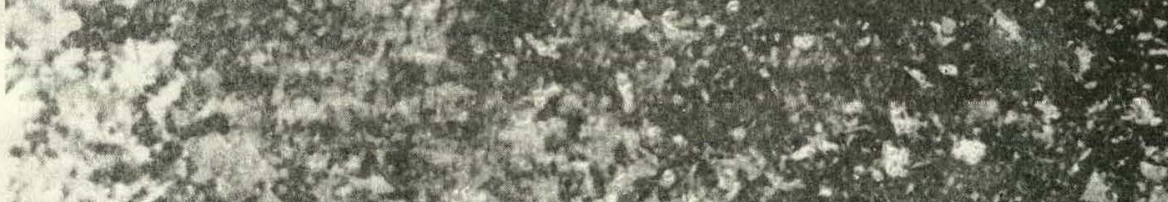

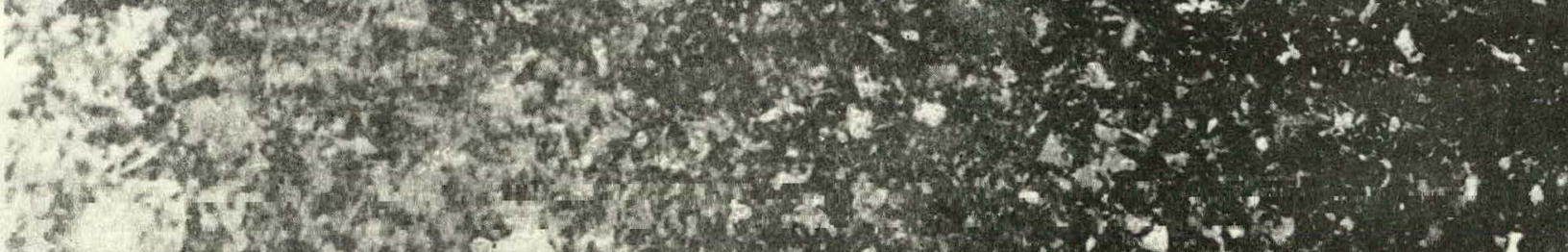

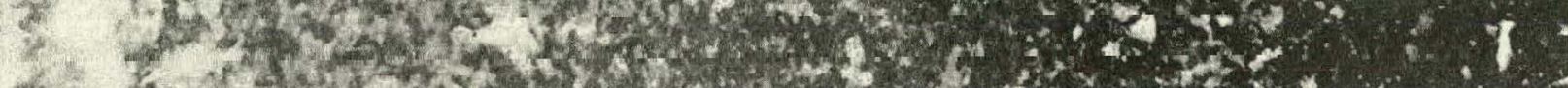

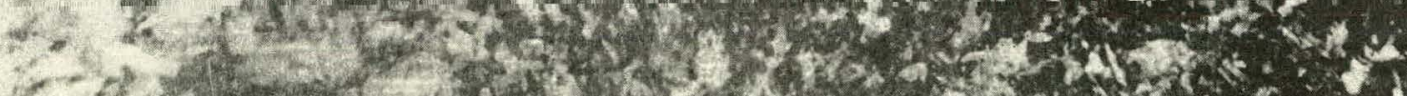

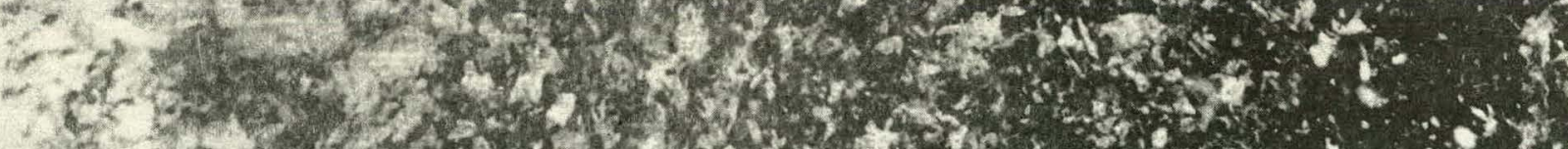

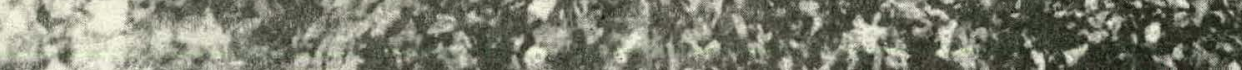

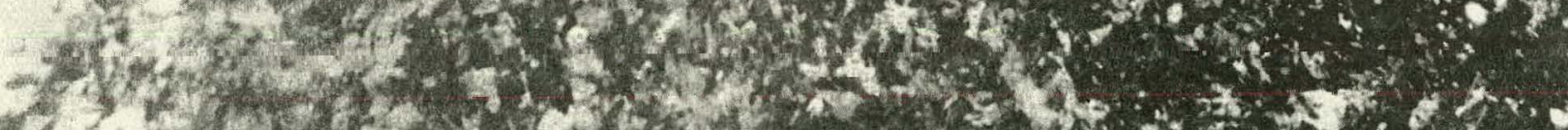

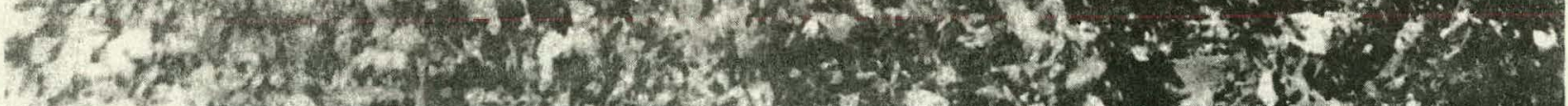

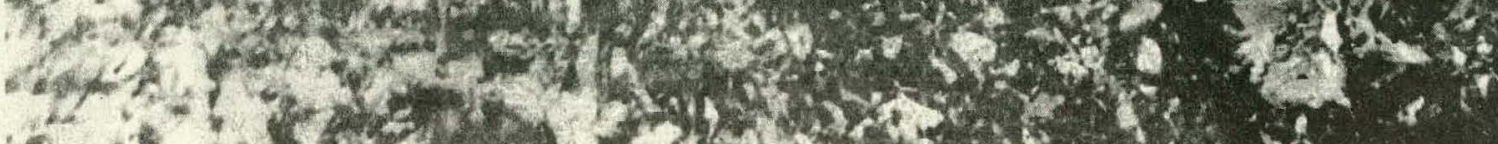

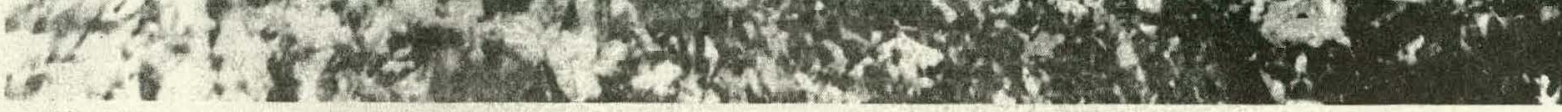

Figure 3.21. Interior of Trommel at $10.6 \mathrm{Mg} / \mathrm{h}$ Infeed Rate and 6 rpm, Baltimore County. 
The trommel is adjusted by the plant operators for individual production requirements. The trommel is normally operated at $6 \mathrm{rpm}$ and a relatively light infeed rate is required to feed the pellet mills. The lower trommel rpm is selected to reduce trommel drive wear.

The trommel variables therefore are:

- Rotational speed - 6 to $12 \mathrm{rpm}$

- Infeed flow rate - 0 to maximum $\mathrm{Mg} / \mathrm{h}$

For any trommel, the question of critical speed is of concern. Particles inside a trommel are subjeçted to centrifugal force, defined as follows.
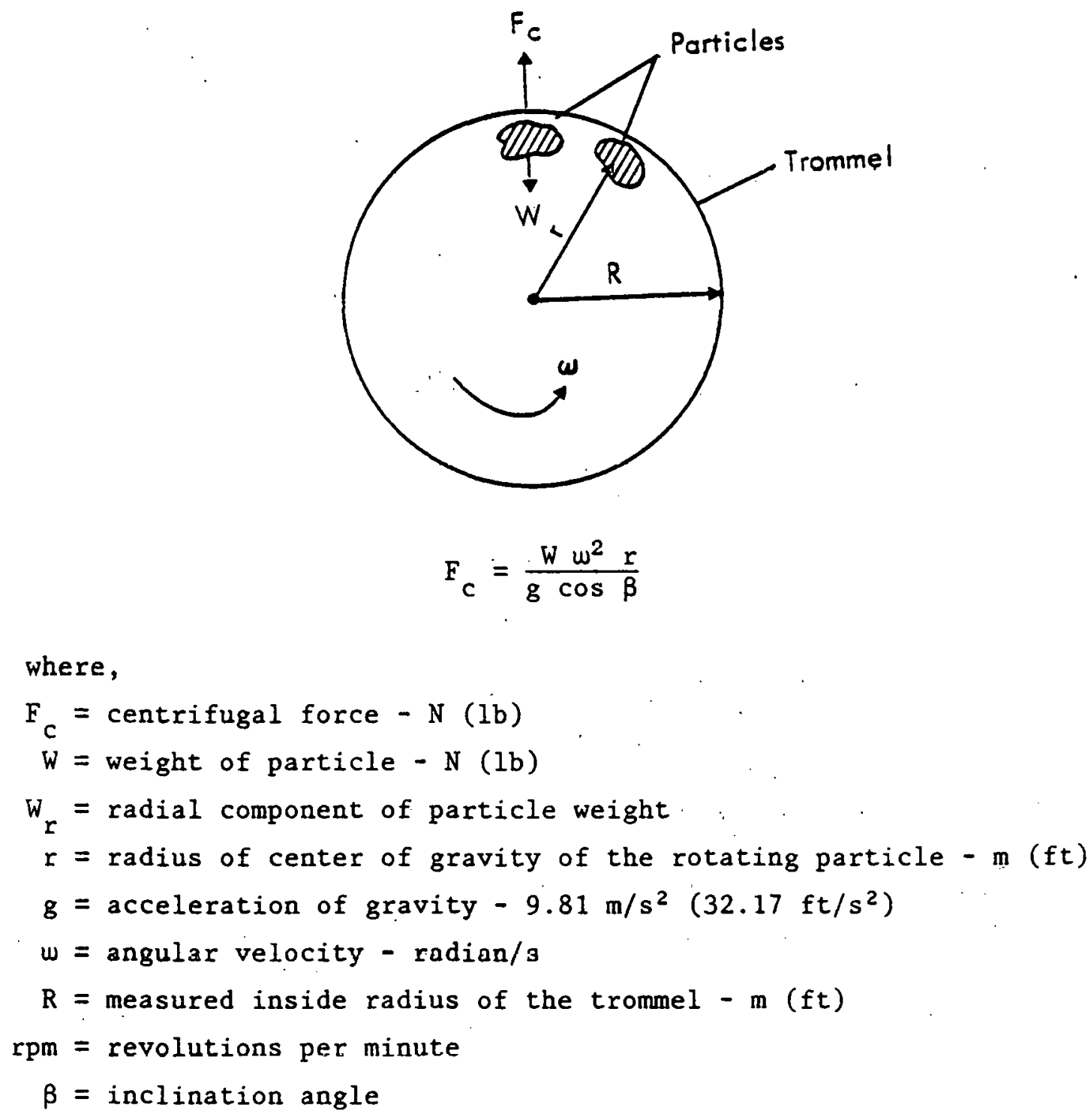
Since a radian is an angle whose arc = radius, in one revolution a point of the circumference of the trommel will travel the circumference, or $2 \pi$ radius.

$$
\mathbf{R}=\mathbf{r} \text { (assumed) }
$$

For a trommel, the radius $R$ is large compared to the particle. Therefore, it may be assumed that the radius of the center of gravity of the particle is equal to the measured inside trommel radius.

As shown in the diagram, the particle will cling to the surface of the trommel when the centrifugal force exceeds the force component of gravity in the radial direction, $F c \geqq W_{r}$. Critical speed is defined as the minimum rotational speed that produces a centrifugal force sufficiently large that the particles do not detach from the screen at top dead center and consequently the material rotates as a flywheel. Ihis point will occur when:

$$
\frac{\omega^{2} r}{8 \cos \beta}=1
$$

The critical speed is calculated as follows.

$$
w_{\text {crit }}=\frac{g \cos \beta}{r}^{0.5}
$$

Expressed in units of $\mathrm{xpm}$ and substituting $R$ for $r$,

$$
\mathrm{rpm}_{\text {crit }}=\frac{60}{2 \pi} \frac{g \cos \beta}{r}^{0.5}
$$

The Baltimore trommel is $3.7 \mathrm{~m}(12 \mathrm{ft})$ in diameter and has a critical speed ot: 22 . $r p m$.

Speeds of 6,9 , and $12 \mathrm{rpm}$ were selected because this covered the practical ranges of the existing variable speed trommel drive. A speed of 12 rpm is 55\% of critical speed. Cal Recovery Systems (CRS) operated a pilot plant trommel of $0.9 \mathrm{~m}$ (3 ft) diameter at $36.6 \mathrm{rpm}$ which is $82.8 \%$ of critical speed. At Baltimore, $18 \mathrm{rpm}$ would be $82 \%$ of critical speed. Efforts to operate the trommel at speeds above $12 \mathrm{rpm}$ by changing gear reducer sheave size were generally unsuccessful because of excessive vibration in the equipment. The plant would not operate at the higher speeds because of the likely increase in maintenance costs. Because the Baltimore trommel contains lifters, the importance of the critical speed consideration was minimized. 


\subsection{FIELD TESTING PROCEDURE}

\subsection{TROMMEL TEST CONDITIONS}

The basic test objectives were to investigate the effects of material retention time and feedrate on trommel performance. During testing and data analysis other important operating and performance relationships were recognized and incorporated into the study. The trommel residence time is determined in part by the trommel rpm. To accomplish the test objectives, the trommel was tested as a function of $\mathrm{rpm}^{\prime} \mathrm{s}$ and infeed flow rates. The nominal test schedule consisted of three rpm's and five flow rates; because the system could not be operated to provide a given flow rate, however, additional tests were performed in each test series, from which 15 tests were selected for analysis.

Each of the 15 tests was conducted four times, fall, winter, spring, and summer, to check for seasonal effects. The total test schedule is shown in Table 4.1 for a total of 60 tests.

TABLE 4.1. SEASONAL TEST SCHEDULE

\begin{tabular}{llc}
\hline & & \\
& & $\begin{array}{c}\text { No. } \\
\text { of } \\
\text { test } \\
\text { runs }\end{array}$ \\
\hline & Month and year & \\
Fall (F) & October 1980 & 15 \\
Winter (W) & January 1981 & 15 \\
Spring (S) & May 1981. & 15 \\
Summer (SM) & August 1981 & 15 \\
& & Total \\
\hline
\end{tabular}

\subsection{FIELD DATA COLLECTE.D}

A summary of data collected during the field tests is provided in $\mathrm{Ta}$ ble 4.2. The detailed testing procedure is provided in Appendix A. 
TABLE 4.2. SUMMARY OF TYPES OF FIELD DATA COLLECTED

Field data collected

Measurement method

Ambient conditions

- Temperature

- Precipitation

- Atmosphere

Trommel rpm

Daily newspaper

Daily newspaper

Visual observation

Flow rate

Trommel energy requirements

Tachometer and visual counting

Residence time

Weight of matcrial (overs and unders) for sampling time

Watts via amprobes and volt meter

Leading edge and indicator material via stop watch and visual observation

Material. samples

2-kg (4.4-1b) sample taken from material removed from belt for flow rate measurement

Bulk density

Weight of $0.2082-\mathrm{m}^{3}(55-\mathrm{gal}$.$) container$ filled with material taken from belt for flow rate measurements

Data tabulated for each of the 60 runs included: (a) trommel rpm; (b) residence time by leading edge of overs $\left(\mathrm{T}_{\mathrm{R} 1}\right)$; (c) residence of tracer cards $\left(T_{R 2}\right)$; (d)-sampling time; (e) total weight of overs and unders; ( $f$ ) bulk density of overs and unders; ( $g$ ) flow rate; and (h) power requirements.

\subsubsection{Trommel RPM}

Trommel rem was measured and set by the tachometer, and test speeds were nominally 6,9 , and $12 \mathrm{rpm}$.

4.2.2 Residence Time in Seconds by Leading Edge of Overs $\left(\mathrm{T}_{\mathrm{R}}\right)$

The leading-èdge residence time was determined by raking back material from the air classifier discharge on the conveyor belt until full flow occurred and a wall of material was formed. The time was then taken from trommel entrance to trommel exit of the wall of material. 
4.2.3 Residence Time of Tracer Cards $\left(\mathrm{T}_{\mathrm{R} 2}\right)$

The residence time of the tracers was the time from trommel entrance to trommel exit of $3 \times 5$ in. $(7.6 \times 12.7 \mathrm{~cm})$ colored card stock.

\subsubsection{Sampling Time in Seconds}

Sampling time was controlled by the individual observing the unders belt. This person started the sampling time on a signal from a person stationed on the overs belt and then terminated the test with a signal to stop all belts when the unders belt was full of material.

\subsubsection{Weight of Overs and Unders Samples}

All material going to the individual unders and overs belts during the timed tests was collected and weighed separately.

\subsubsection{Bulk Density of Overs and Unders}

A tared 55-gal. drum was loosely filled and weighed with each of the unders and overs materials. Bulk density was calculated on a basis of weight per unit volume.

\subsubsection{Flow Rate in Weight per Hour}

The total weight of unders and overs for a timed run was divided by the time of the run to provide an average flow rate for the duration of the test.

\subsubsection{Power Requirements}

The power requirements of the 10-hp trommel motor were determined by the use of amprobes on each of the three power leads and the monitoring of line voltage. The product of the average of the three amprobe readings times the monitored voltage times $\sqrt{3}$ times an assumed power factor of 0.85 provided a power requirement of the trommel for each test.

\subsection{SAMPLES COLLECTED FOR LABORATORY ANALYSIS}

Duplicate samples of approximately $2 \mathrm{~kg}(\sim 4-1 / 2 \mathrm{lb})$ were taken from the overs and unders from each test run. Material was randomly handpicked from the overs fraction and the unders fraction was sampled by the cone and quarter techniques (see Section 6.1). Individual samples were double bagged and labeled inside and out. One series of samples was packaged into 55-gal. fiber drums and shipped to CRS laboratories in Richmond, California, for analysis. The duplicate series of samples was stored at the test site pending receipt of the set of samples at CRS. All the samples arrived in good condition at CRS. CRS analyzed samples from 15 of the tests from each test series after preliminary calculations to choose the most informative set of tests. 


\subsection{FIELD TEST SCHEDULE}

The four series of field tests were conducted as functions of trommel rotational speed and infeed flow. rate. The infeed rate to the trommel was established by setting the diverter to direct a uniform amount of flow from belt 14 to belt 15 (see Figure 3.5). It was not possible to provide a predetermined flow rate. The flow rate was increased or decreased based on the subjective judgment of the diverter operator, and extra test runs were performed in order to span the range of flow rates of interest. Maximum infeed rate for the trommel is approximately $40 \mathrm{Mg} / \mathrm{h}$, and tests were conducted close to this maximum.

On arrival of the field test crew at the facility, the trommel was examined for the degree of blinding (holes in the trommel plugged with material). When necessary, the trommel was thoroughly cleaned prior to initiation of tests. Visual observation throughout the test series indicated that the trommel remained on the order of $2 \%$ blinded.

\subsubsection{Field Test Series No. 1}

The autumn series of field tests was performed at the Baltimore County facility during the week of October 20, 1980. Weather throughout the test period was mild and clear with temperatures ranging from $4.5^{\circ}$ to $22.8^{\circ} \mathrm{C}\left(40^{\circ}\right.$ to $73^{\circ} \mathrm{F}$ ). Twenty tests were conducted at trommel rotational speeds of 6,9 , and $12 \mathrm{rpm}(27,41$, and $55 \%$ of critical speed) and at trommel infeed rates ranging from 0.36 to $38.5 \mathrm{Mg} / \mathrm{h}$. Fifteen of the 20 tests were subsequently selected for analysis. Table 4.3 shows the overall test matrix and the tests selected for study.

TABLE 4.3. MATRIX OF TEST SERIES NO. 1

\begin{tabular}{ccc}
\hline & Rotational and circumferential speed \\
\hline $6 \mathrm{rpm}$ & $9 \mathrm{rpm}$ & $12 \mathrm{cpm}$ \\
$(1.15 \mathrm{~m} / \mathrm{s})$ & $(1.72 \mathrm{~m} / \mathrm{s})$ & $(2.30 \mathrm{~m} / \mathrm{s})$ \\
\hline & & \\
$0.36 \mathrm{Mg} / \mathrm{h}$ & $2.82 \mathrm{Mg} / \mathrm{h}^{*}$ & $1.70 \mathrm{Mg} / \mathrm{h}$ \\
$1.76 \mathrm{Mg} / \mathrm{h}^{*}$ & $5.85 \mathrm{Mg} / \mathrm{h}^{*}$ & $3.43 \mathrm{Mg} / \mathrm{h}^{*}$ \\
$3.13 \mathrm{Mg} / \mathrm{h}^{*}$ & $6.30 \mathrm{Mg} / \mathrm{h}^{*}$ & $9.11 \mathrm{Mg} / \mathrm{h}^{*}$ \\
$4.74 \mathrm{Mg} / \mathrm{h}^{*}$ & $10.55 \mathrm{Mg} / \mathrm{h}^{*}$ & $13.62 \mathrm{Mg} / \mathrm{h}^{*}$ \\
$12.84 \mathrm{Mg} / \mathrm{h}^{*}$ & $15.86 \mathrm{Mg} / \mathrm{h}^{*}$ & $15.10 \mathrm{Mg} / \mathrm{h}$ \\
$21.30 \mathrm{Mg} / \mathrm{h}$ & $22.55 \mathrm{Mg} / \mathrm{h}^{*}$ & $30.27 \mathrm{Mg} / \mathrm{h}^{*}$ \\
$23.91 \mathrm{Mg} / \mathrm{h}^{*}$ & & $38.52 \mathrm{Mg} / \mathrm{h}^{*}$ \\
& & \\
\hline
\end{tabular}

* Samples from these tests were selected for analysis. 


\subsubsection{Field Test Series No. 2}

The winter series of field tests was performed during the week of January 26, 1981. Eighteen tests were conducted at trommel speeds of 6,9 , 12 , and $15 \mathrm{rpm}(27,41,55$, and $67.5 \%$ of critical speed) and at trommel infeed rates ranging from 0.96 to $33.49 \mathrm{Mg} / \mathrm{h}$. Weather conditions during the tests were clear with temperatures ranging from $3.3^{\circ}$ to $13.9^{\circ} \mathrm{C}\left(38^{\circ}\right.$ to $57^{\circ} \mathrm{F}$ ). Table 4.4 shows the test matrix. The three tests at $15 \mathrm{rpm}$ were not selected for analysis because excessive vibration at this speed indicated that it would be unpractical to operate the trommel at $15 \mathrm{rpm}$ on a continuous plant production basis. Thus, results from 15-rpm tests would be meaningless as they would not be indicative of results within the trommel operating range. The remaining samples at the slower rpm's were all selected for analysis.

TABLE 4.4. MATRIX OF TEST SERIES NO. 2

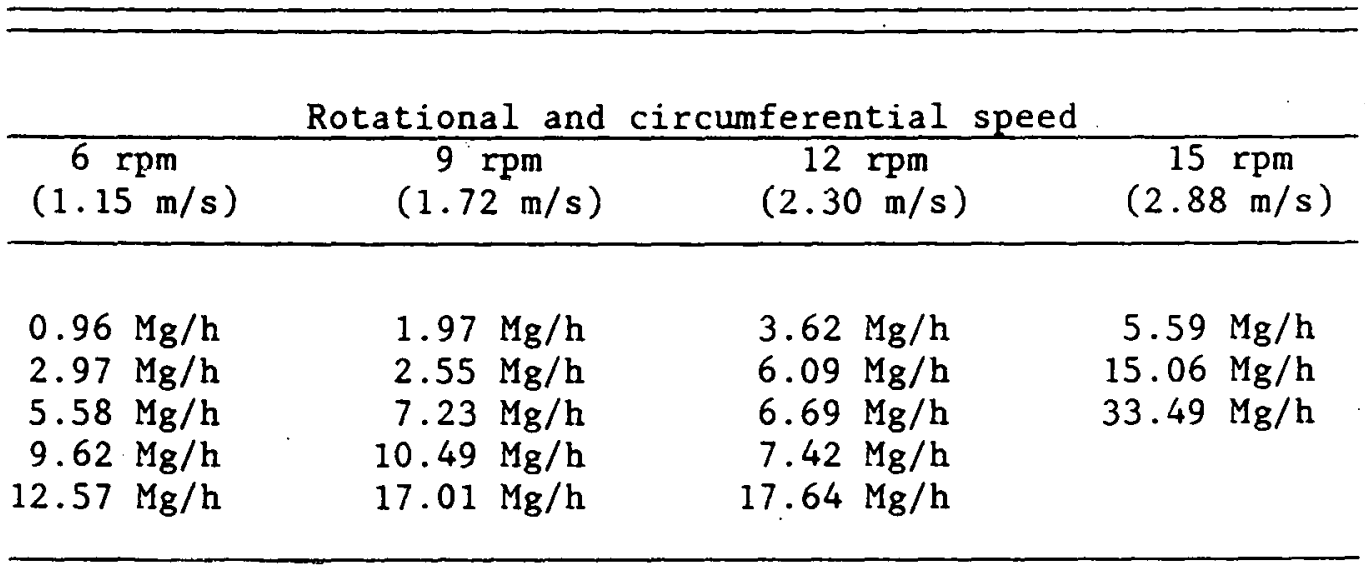

\subsubsection{Field Test Series No. 3}

The spring series of field tests was conducted during the week of May 4, 1981. Seventeen tests were ronducted at trommel speeds of 6,9 , and $12 \mathrm{rpm}$ and at trommel infeed rates ranging from 2.8 to $46.7 \mathrm{mg} / \mathrm{h}$. Samples from 15 of these tests were selected for analysis. Weather conditions during the tests were clear with temperatures ranging from $12.8^{\circ}$ to $26.7^{\circ} \mathrm{C}\left(55^{\circ}\right.$ to $\left.80^{\circ} \mathrm{F}\right)$. A pronounced compositional difference from the fall and winter samples was evident due to the large quantity of grass clippings in the municipal waste. Table 4.5 shows the test matrix. 
TABLE 4.5. MATRIX OF TEST SERIES NO. 3 $(\mathrm{Mg} / \mathrm{h}$ versus $\mathrm{rpm})$

Rotational and circumferential speed

\begin{tabular}{ccc}
\hline $6 \mathrm{rpm}$ & $9 \mathrm{rpm}$ & $12 \mathrm{rpm}$ \\
$(1.15 \mathrm{~m} / \mathrm{s})$ & $(1.72 \mathrm{~m} / \mathrm{s})$ & $(2.30 \mathrm{~m} / \mathrm{s})$
\end{tabular}

$2.82 \mathrm{Mg} / \mathrm{h} *$

$6.32 \mathrm{Mg} / \mathrm{h} *$

$2.60 \mathrm{Mg} / \mathrm{h}$

$5.05 \mathrm{Mg} / \mathrm{h} *$

$6.48 \mathrm{Mg} / \mathrm{h}$ *

$2.92 \mathrm{Mg} / \mathrm{h}$ *

$5.21 \mathrm{Mg} / \mathrm{h}^{*}$

$8.56 \mathrm{Mg} / \mathrm{h}^{\text {th }}$

$9.90 \mathrm{Mg} / \mathrm{h} *$

$29.10 \mathrm{Mg} / \mathrm{h}$

$31.67 \mathrm{Mg} / \mathrm{h}$ *

$10.59 \mathrm{Mg} / \mathrm{h}$ *

$26.44 \mathrm{Mg} / \mathrm{h} *$

$32.90 \mathrm{Mg} / \mathrm{h}$ *

$17.69 \mathrm{Mg} / \mathrm{h} *$

$29.56 \mathrm{Mg} / \mathrm{h}$ *

$46.55 \mathrm{Mg} / \mathrm{h} *$

* Samples from these tests were selected for analysis.

\subsubsection{Field Test Series No. 4}

The summer series of field tests took place during the week of August 17 , 1981. Fifteen tests were conducted at trommel speeds of 6,9 , and $12 \mathrm{rpm}$ and at trommel infeed rates ranging from 1.47 to $33.28 \mathrm{Mg} / \mathrm{h}$ (Table 4.6 ).

TABLE 4.6. MATRIX OF TEST SERIES NO. 4

Rotational and circumferential speed

\begin{tabular}{rrr}
\hline $\begin{array}{c}6 \mathrm{rpm} \\
(1.15 \mathrm{~m} / \mathrm{s})\end{array}$ & $\begin{array}{c}9 \text { Lpil } \\
(1.72 \mathrm{~m} / \mathrm{s})\end{array}$ & $\begin{array}{c}12 \\
\mathrm{rpm}\end{array}$ \\
\hline & & \\
$2.64 \mathrm{Mg} / \mathrm{h}$ & $1.47 \mathrm{Mg} / \mathrm{h}$ & $2.11 \mathrm{Mg} / \mathrm{h}$ \\
$3.56 \mathrm{Mg} / \mathrm{h}$ & $6.91 \mathrm{Mg} / \mathrm{h}$ & $2.41 \mathrm{Mg} / \mathrm{h}$ \\
$7.80 \mathrm{Mg} / \mathrm{h}$ & $10.17 \mathrm{Mg} / \mathrm{h}$ & $4.91 \mathrm{Mg} / \mathrm{h}$ \\
$10.63 \mathrm{Mg} / \mathrm{h}$ & $12.71 \mathrm{Mg} / \mathrm{h}$ & $13.79 \mathrm{Mg} / \mathrm{h}$ \\
$23.26 \mathrm{Mg} / \mathrm{h}$ & $33.28 \mathrm{Mg} / \mathrm{h}$ & $32.06 \mathrm{Mg} / \mathrm{h}$ \\
\hline
\end{tabular}

Weather conditions during the tests were clear with temperatures ranging from 12.8 to $26.7^{\circ} \mathrm{C}\left(55\right.$ to $\left.80^{\circ} \mathrm{F}\right)$. The pronounced compositional difference from the fall and winter samples was again evident, as it had been in the spring series of tests, due to the large quantity of grass clippings in the municipal waste. 


\subsection{FIELD TESTING PROBLEMS}

The general conduct of the test runs was quite smooth, and the help and cooperation of the plant personnel were excellent. The most pronounced problem was the inability to establish given infeed flow rates, which resulted in numerous runs being scrubbed and time loss due to the necessity to clear the system prior to starting the next run. Additionally, several runs in excess of the nominal 15 runs per test series were conducted to insure an acceptable range of infeed rates (the infeed rate was calculated subsequent to the test run). Few runs needed to be scrubbed due to human error, such as losing track of sampling time, missed signals, and confusion resulting from plant crew changes. Mechanical problems resulting in lost time and scrubbed test runs included stop watch malfunction, malfunction of a conveyor control switch, and trommel rotation stopping due to an unbalanced load.

Efforts to conduct tests at trommel rotational speeds greater than $12 \mathrm{rpm}$ resulted in excessive trommel vibration and stress cracking of the steel trommel drive ring which is in contact with a steel drive wheel. Therefore, $12 \mathrm{rpm}$, which is $55 \%$ of critical speed, is the maximum speed for this trommel design.

Ali test runs selected for evaluation and product testing were problem free and, to the best of our knowledge, anomaly free. Thus, the test runs represent conditions which could be achieved under continuous commercial production operations. All parameters for these runs were as precise and accurate as possible within the constraints of the test plan. 
THIS PAGE

\section{WAS INTENTIONALLY LEFT BLANK}




\subsection{LABORATORY ANALYSIS PROCEDURES}

\subsection{SUBSAMPLING OF GROSS SAMPLES}

Gross samples were subsampled for analyses using the mixing and quartering technique. In this technique; the material is mixed and formed into a loose conical pile and divided vertically into quarters. Two opposite quarters are discarded and the remaining two are mixed and again formed into a conical pile. The procedure is repeated until the desired sample size is obtained.

\subsection{AIR-DRY MOISTURE ANALYSIS}

The air-dry moisture content of the test samples was determined by drying the samples at $22^{\circ} \mathrm{C}\left(72^{\circ} \mathrm{F}\right)$ and $65 \%$ relative humidity until they showed no further loss in weight. Air-dry moisture content is reported as: (asreceived weight minus air-dry weight)/(as-received weight).

\subsection{SIZE DISTRIBUTION ANALYSIS}

The size distributions of the test samples were determined after airdrying of the samples with the use of manual and mechanical screening apparatus. Manual screening was employed for material that exceeded $5 \mathrm{~cm}$. Mechanical screening was used for material less than $5 \mathrm{~cm}$. Size distribution data are presented on an air-dry weight basis.

\subsection{COMPOSITION ANALYSIS}

The composition of the test samples was determined by manually sorting the components. The components are paper and plastic, ferrous, nonferrous, glass, organic other, inorganic other, and material passing a 14 mesh (1.30 $\mathrm{mm}$ ) sieve, termed fines. In the category organic other is included organic material other than paper and plastic, for example, cloth, garden waste, and wood. The category inorganic other includes inorganic material other than glass, metals, and less than $1.30-\mathrm{mm}$ fines. Sorting of the components was done by size class. The exact composition of the fines is unknown as the individual particles are too small for visual analysis. It is assumed the less than $1.30-\mathrm{mm}$ fines are primarily noncombustible items such as glass, sand, and dirt.

Composition data are prsented on an air-dry weight basis. 


\subsection{OVEN-DRY MOISTURE ANALYSIS}

The oven-dry moisture content was determined by drying subsamples of material at $100^{\circ} \mathrm{C}\left(212^{\circ} \mathrm{F}\right)$ until constant weight was achieved. The subsamples were prepared by milling the material to less than $6 \mathrm{~mm}$ and selecting a representative $15-$ to 20-g sample using the coning and quartering technique.

\subsection{ASH CONTENT ANALYSIS}

The material was prepared by milling it to less than $6 \mathrm{~mm}$ in size, selecting a $15-$ to $20-g$ representative sample using the cone and quartering technique, and subjecting it to oven-drying.

The ash content of the samples was determined in accordance with ASTM Standard D 3174, adapted for use with shredded refuse. The oven-dry subsamples were ignited in a muffle furnace held at a temperature of $700^{\circ}$ to $725^{\circ} \mathrm{C}$ ( $1292^{\circ}$ to $\left.1337^{\circ} \overrightarrow{\mathrm{F}}\right)$. Samples remained in Lhe furnace until no weight loss was registered. Ash content results are reported on an oven-dry weight basis and calculated as (final weight)/(oven-dry weight) $\times 100 \%$.

\subsection{HEATING VALUE ANALYSIS}

The heating value analyses were performed by adiabatic bomb calorimetxy in accordance with ASTM Standard D 2015, adapted for refuse. Representative subsamples of material were prepared by milling the material to less than $1 \mathrm{~mm}$ size and selecting from the milled material a representative subsample of 15 to $20 \mathrm{~g}$. Following oven-drying of the $15-$ to $20-\mathrm{g}$ sample, a representative 1- 8 subsample was selected for calorific determination. The calorific determinations are reported in terms of the higher heating value and are presented on an oven-dry weight basis. 


\title{
6.0 TEST RESULTS
}

\subsection{OPERATION AND PERFORMANCE}

The results of the field tests have been compiled into the following tables for clarity of presentation. Appendix B contains the component/size distributions of the feed, oversize, and undersize for each of the 60 test runs. Fifteen test runs are associates with each of the quarterly testing periods. Appendix C contains screening performance data and properties of the feed, oversize, and undersize fractions. Data for the feed, oversize, and undersize fractions are used in the development of the performance characterization parameters. The first table in Appendix $C$ describes the organization of the appendix with respect to the contents of the tables and with respect to the corresponding quarterly testing period. Four tables of test results are presented for each of the testing periods.

All key performance parameters, except for Ash/Energy of the Oversize Fraction, have been normalized in terms of the input properties (i.e., those calculated for the feed material) in order to eliminate as much as possible the variations in trommel performance that would be attributable to changes in the properties of the feed material. A considerable variation in the properties of the feed material was found during the study (as discussed in Section 6.2). The rationale, validity, and significance of the method of normalization in terms of feedstock properties has been published previously ${ }^{1,2}$ and was used for air classifier performance characterization.

The key screening performance parameters are:

\author{
Screening Efficiency (percent) \\ Ash Content Removal (perrent) \\ Moisture Content Removal (percent) \\ Organic Content Improvement (percent) \\ Organic Recovery (percent) \\ Heating Value Improvement (percent) \\ Energy Recovery (percent) \\ Ash per Energy Content of Oversize Fraction $(\mathrm{kg} / \mathrm{GJ})$
}

The definitions of the key parameters are presented in the glossary while their description and significance are discussed in Section 7, "Performance Characterization."

Wide variations may be observed in the material properties and in the performance parameters presented in Appendix C. Variations in the feed are 
due to seasonal variations, as well as the basic heterogeneity of MSW. The properties of the oversize and undersize fractions are dependent upon the properties of the feed and upon trommel operating conditions. Similarly, screening performance parameters are a function of the properties of the feed material and of trommel operating conditions. A detailed interpretation of trommel operation and performance is presented in Section 7.

Also included in the test result tables of Appendix $C$ are the measurements taken of residence time. Although the residence time of the material within a trommel screen is a key parameter in terms of analyzing the particle dynamics, the study team achieved only limited success in obtaining consistent data. Neither timed measurements of the leading edge nor of card tracers inserted with the feed material provided satisfactory results. Despite the fact that the methods had been developed and tried previously, ${ }^{3}$ the residence time measurements at the Baltimore County site produced variations that in some cases defy physical interpretation. As one example, the rracer residence time data for the May 1981 tests ronducted at $6 \mathrm{rpm}$ shuw no discernible trend despite a ten-fold increase in feedrate. The latter example is by no means the only one to illustrate the point. The variations in the residence time data (i.e., that data lacking an interpretation) apparently are a consequence of the method of measurement, the bias of the visual observer, and the complexity of particle motion inside of the trommel. Based upon the finding in this study, a method of residence time measurement needs to be developed, tested, and interpreted. The reason is that residence time is a key parameter for equipment design and for developing and verifying the governing relations for tromneling. The present study identifies the need and at the same time provides data that may serve as a general range of residence times that are encountered under specific operating conditions and using specific methods of residence time measurement.

\subsection{SEASONAL VARIATIONS}

Inasmuch as seasonal variatione occur in the cumpustitin of municipal solid waste, one of the objectives of the study was to determine the effect of such variations in composition on trommel performance. The results of the four field tests in terms of trommel feed characteristics are shown in Table 6.1.

The average characteristic and nominal particle sizes of the tromiel feed were found co vary substantially at different times of the year. Figure 6.1 depicts the average characteristic and nominal particle sizes ( 63.2 and 90 cumulative percent passing, respectively) of 15 test runs for each test period. The error bars indicate the $95 \%$ confidence linits. The smallest particle sizes occurred in summer and the largest in winter. The characteristic particle size was over twice as large in winter as it was in summer and the nominal size was approximately $50 \%$ higher in winter than in summer. The second smallest particle sizes occurred in spring and the third smallest occurred in the fall. The large number of grass clippings present in the feed in summer is one major reason that the characteristic and nominal particle sizes are smallest at that time. 
TABLE 6.1. SEASONAL VARIATIONS IN TROMMEL FEED CHARACTERISTICS

(Average Values for 15 Runs in Each Test Period)

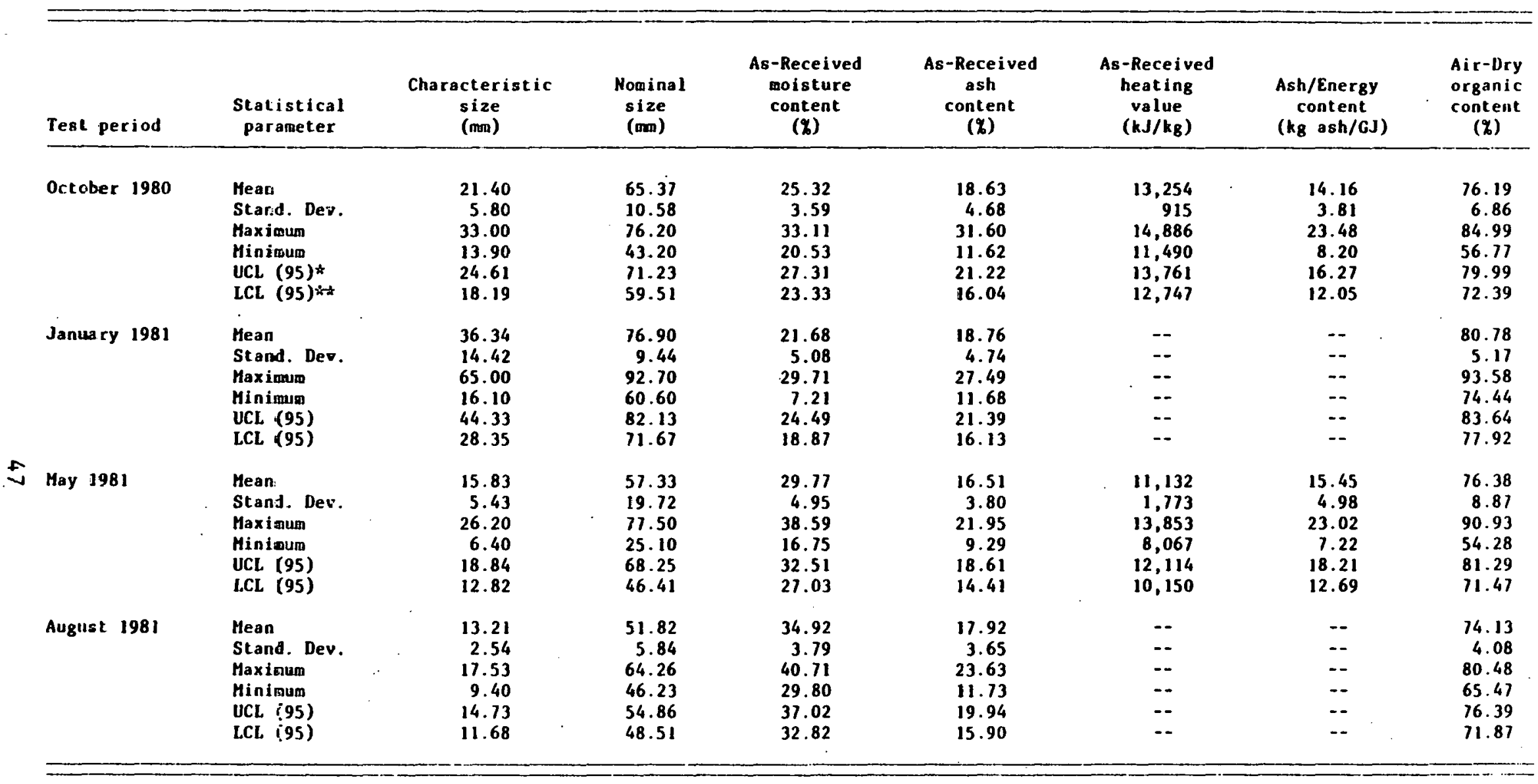

* UCL $(95)=$ Upper $95 \%$ confidence 1 imit.

$\therefore$ LCL $(95)=$ Lower $95 \%$ confidence 1 imit . 


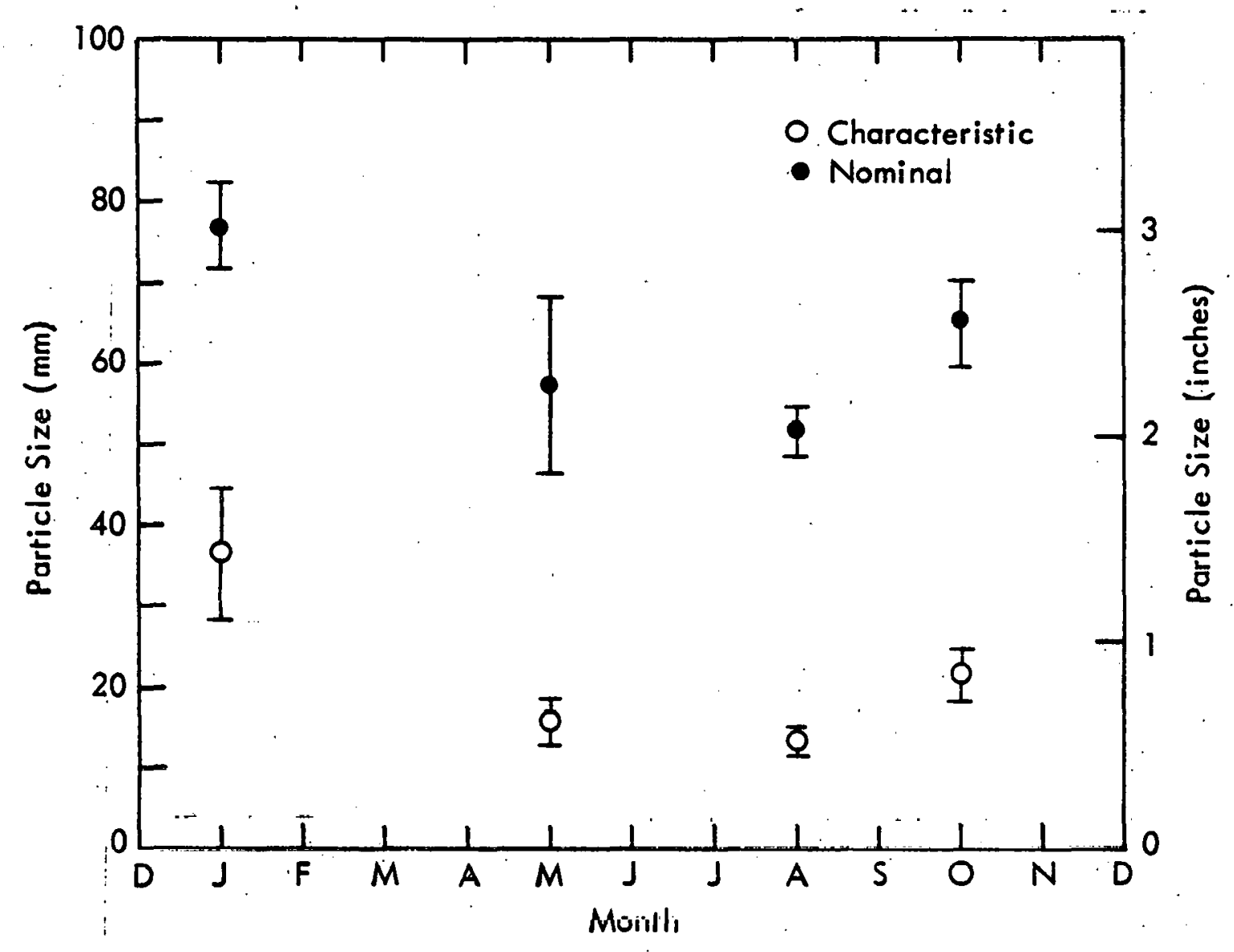

Figure 6.1. Seasonal Varlations of the Characteristic and Nominal Particle Slze of the Feed to the Tromel. 
The average ash content and average moisture content of the trommel. feedstock during different seasons are shown in Figure 6.2. The values presented are the averages of 15 test runs for each test period. The ash content was essentially constant throughout the year; however, the moisture content varied significantly throughout the year. In order of occurrence of the largest moisture contents of the feed, the seasons of the year are: summer, spring, fall, and winter. The moisture content of the trommel feed was approximately $70 \%$ higher in summer than it was in winter. The large proportion of garden wastes in the MSW during the spring and summer is partially responsible for the high moisture content. Inasmuch as no precipitation occurred during any of the test periods, rainfall did not contribute to the seasonal discrepancies in moisture content of the feedstock.

The organic content and the heating value of the trommel feedstock are shown in Figure 6.3 as the average of the 15 test runs for each test period. The oganic content is presented on an air-dry basis and the heating value is presented on an as-received basis. It is not possible to report the organic content on an as-received basis inasmuch as the component/size distributions were performed after air drying and the moisture content of the individual components were not determined. The data in the figure indicate that the variation in organic content is small and that the trend for the highest organic content occurs in an order that is precisely the opposite as cited for the trend for the highest moisture content. Consequently, on an as-received basis, the organic content would probably be relatively constant.

Also shown in Figure 6.3 , is the seasonal variaton in the heating value of the trommel feedstock. The $20 \%$ difference in the as-received heating values for the feedstock from May and October is a result of a higher moisture content and a lower heating value (oven-dry basis) for the feed material encountered in the May tests.

No conclusions have been drawn with respect to the variations in screening performance parameters over the different seasons of the year because of the impossibility of identifying one performance parameter that varies while the others remain invariant. For example, there are no two test runs in different test periods that have identical feed rates and rotational speeds. 


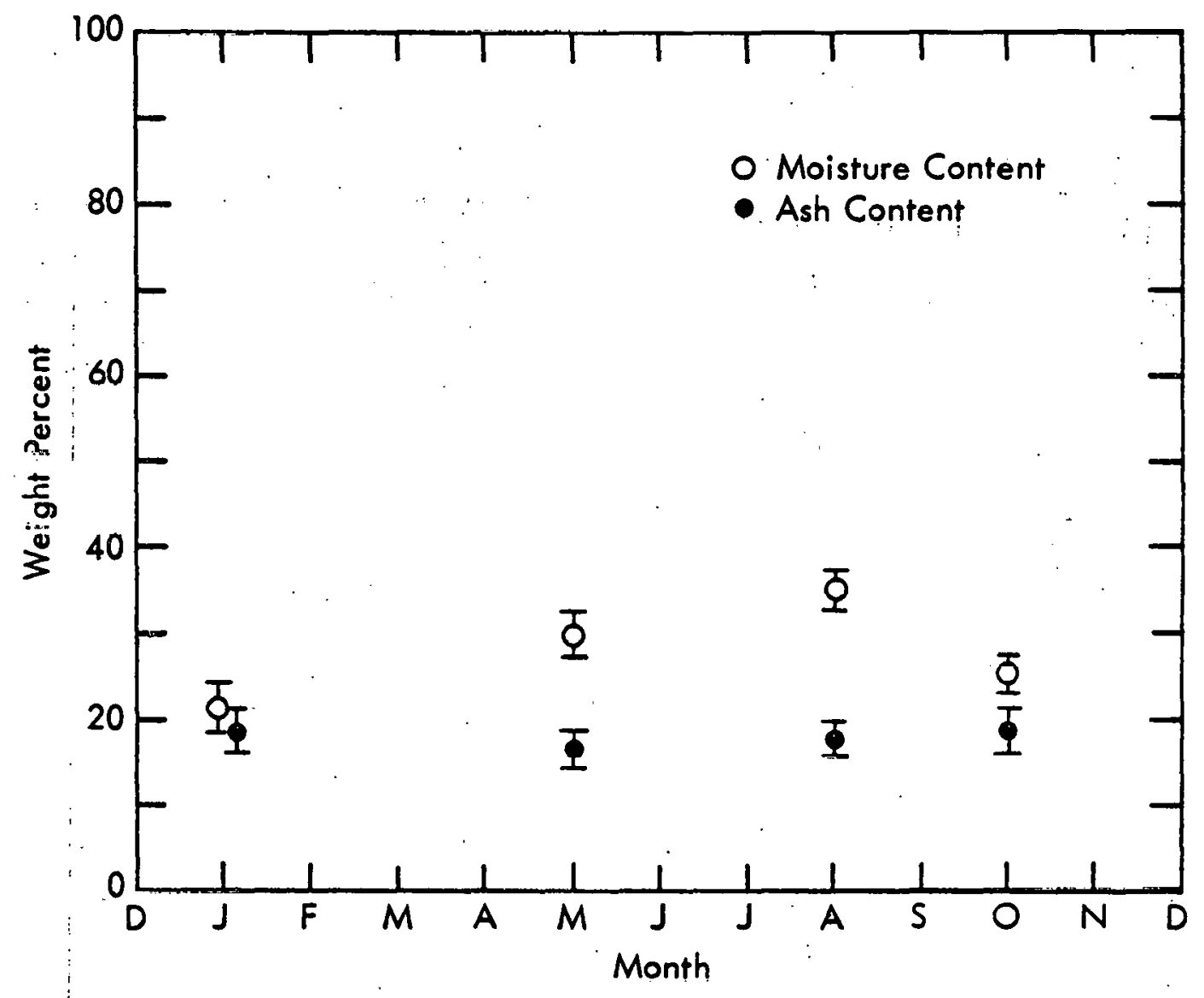

Figure 6.2. Seasonal Variations of the Ash Content and the Moisture Content of the Feed to the Trommel. 


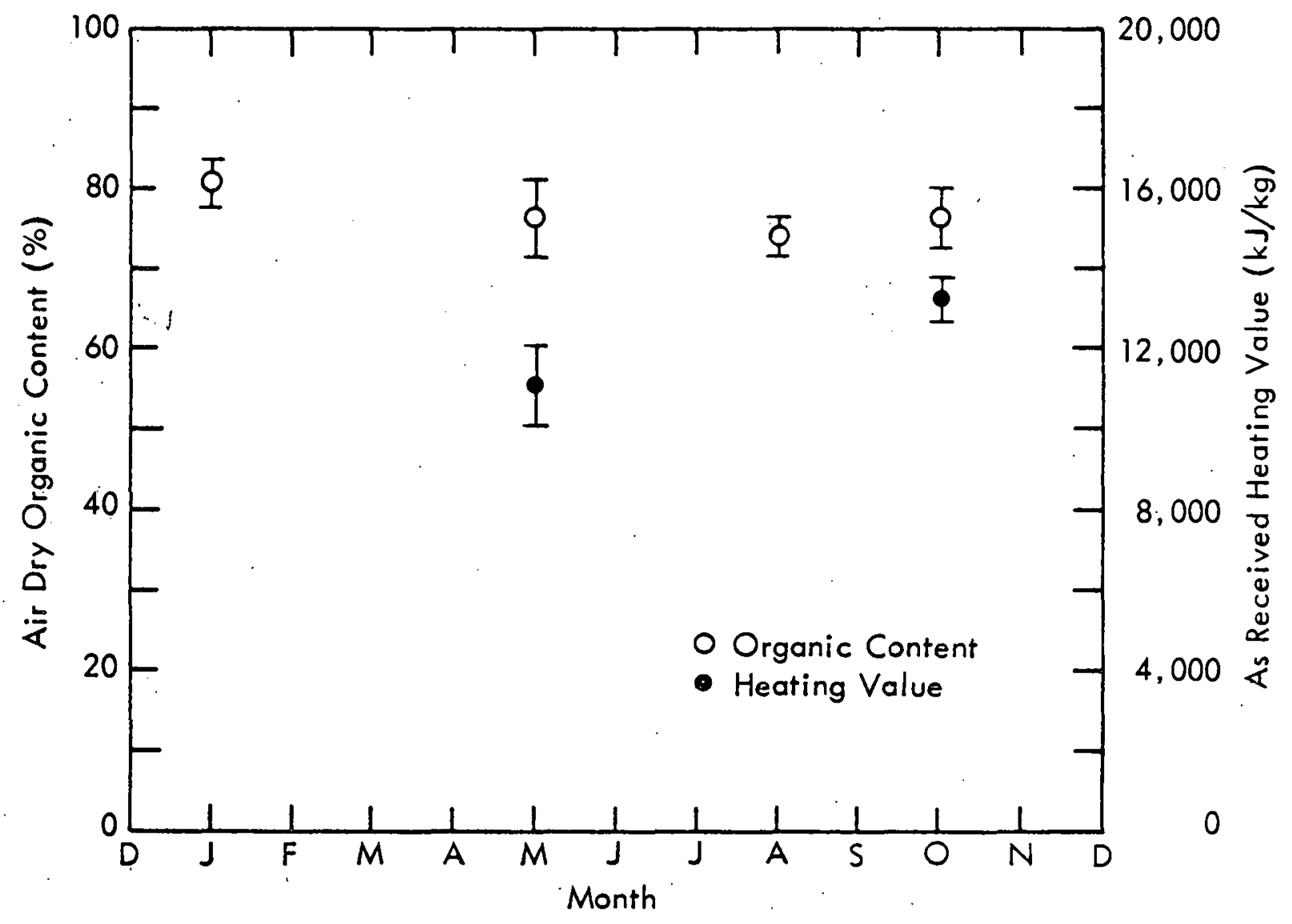

Figure 6.3. Seasonal Varlations of the Organic Content and the Heating Value of the Feed to the Trommel. 


\section{THIS PAGE WAS INTENTIONALLY LEFT BLANK}




\subsection{PERFORMANCE CHARACTERIZATION}

This section characterizes trommel performance for the four series of tests. Table 7.1 provides a guide to figures showing performance characterization plots. Component/size distribution data are provided in Appendix B, and summary tables of trommel performance data and properties of the feed, oversize, and undersize fractions are provided in Appendix $C$.

\subsection{SCREENING EFFICIENCY}

The parameter most commonly used for the characterization of screening performance is the screening efficiency. This parameter represents the percentage of undersize material entering the screen that passes through the apertures in the screen to the undersize conveyor belt. In equation form, screening efficiency $(n)$ can be formulated in several ways. The following form was used for purposes of this study:

$$
\eta \equiv \frac{\dot{m}_{u}}{\dot{m}_{u}+U_{o} \dot{m}_{o}}
$$

where,

$\dot{m}_{u}=$ flow rate of the undersize fraction

$\dot{m}_{0}=$ flow rate of the oversize fraction

$U_{0}=$ fraction of true undersize material in the oversize fraction

The effects of feedrate and rotational speed on screening efficiency are shown in Figure 7.1. Results for. each of the four testing periods are presented in the figure. One test in May at $46.55 \mathrm{Mg} / \mathrm{h}$ feedrate and $12 \mathrm{rpm}$ was not plotted in Figure 7.1 nor in any subsequent figures for the purpose of convenience in figure construction. The data for this test are contained in the relevant Appendices $B$ and $C$ tables.

Figure 7.1 indicates that for a given set of operating conditions, screening efficiency decreases as feedrate increases. This effect is the result of the increased bed depth with increased feedrate and a concomitant increase in the probability that an aperture is covered. Within the range of measured feedrates tested, nominally 1 to $40 \mathrm{Mg} / \mathrm{h}$, the decrease in efficiency with increased feedrate appears to be linear. Typical operating 
TABLE 7.1. GUIDE TO PERFORMANCE CHARACTERIZATION PLOTS

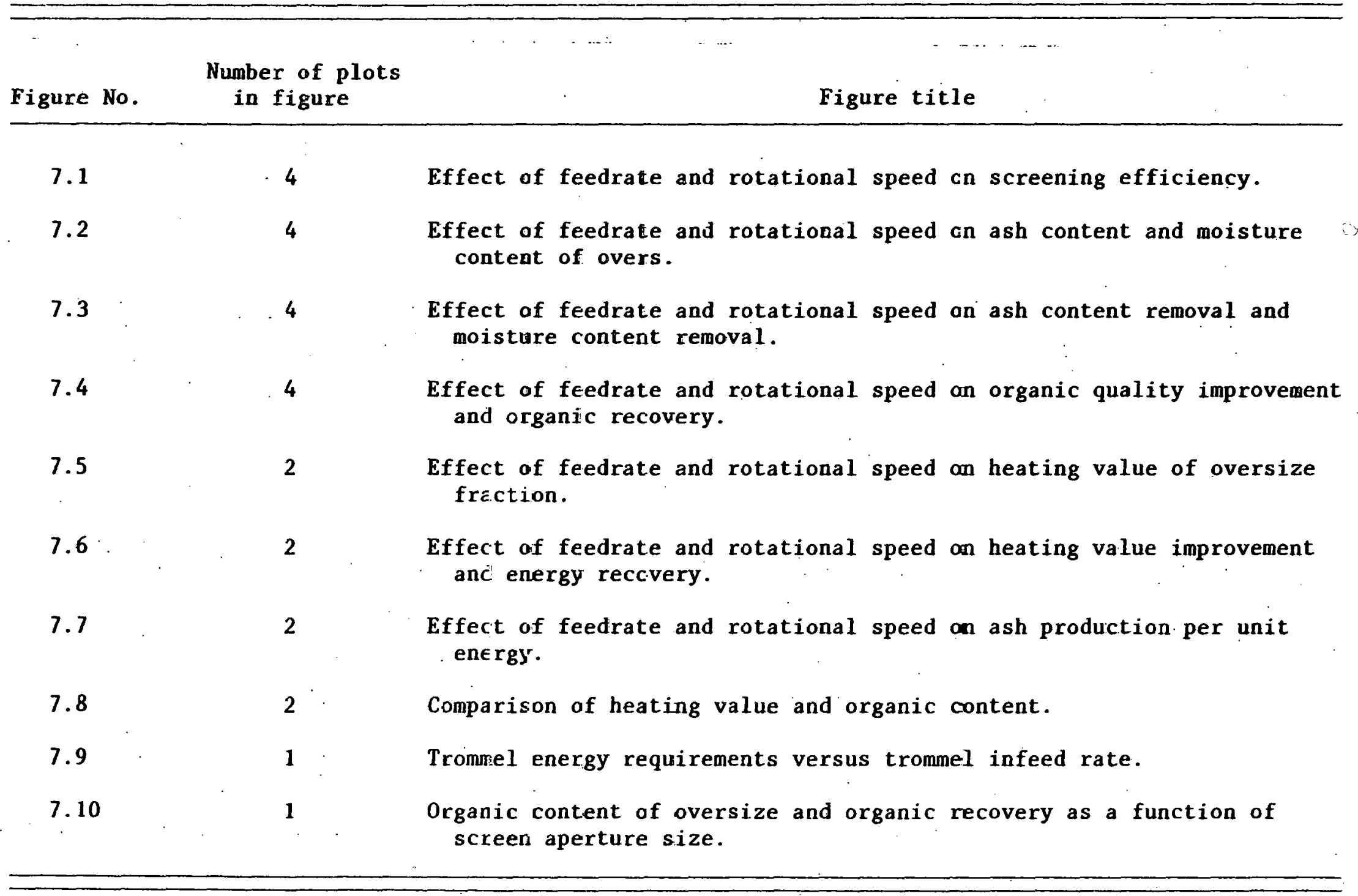



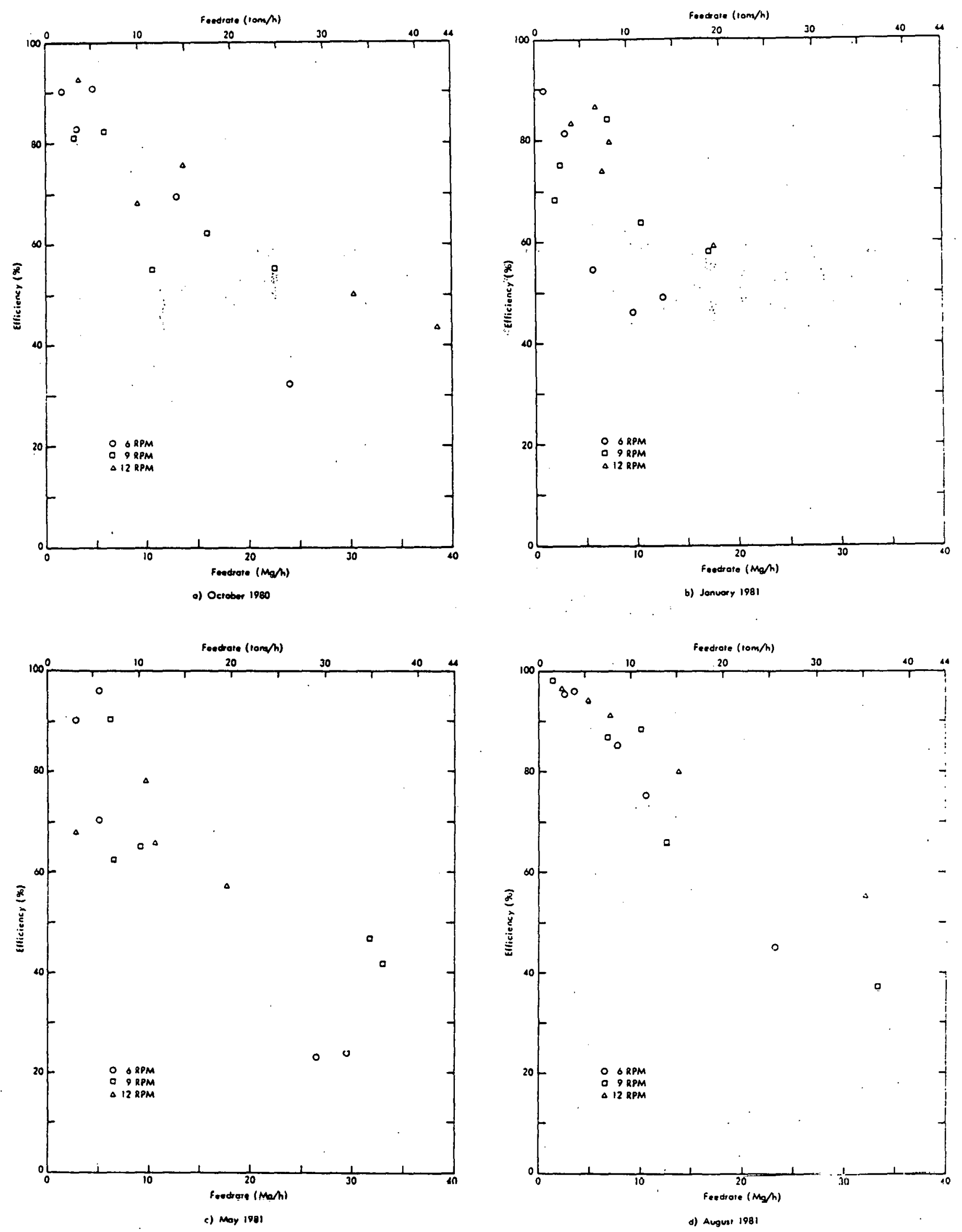

Figure 7.1. Effect of Feedrate and Rotational Speed on Screening Efficiency. 
feedrates at the plant are in the range of 7 to $13 \mathrm{Mg} / \mathrm{h}$. Thus, the linear relationship between efficiency and feedrate holds for the range of feedrates encountered at the plant. Moreover, the linear relationship extends to efficiencies below $40 \%$, which are beyond the practical operating limits (in terms of feedrate capacity) of the screen. For feedrates greater than those tested, it is conjectured that the linear relationship between efficiency and feedrate would break down.

In the range of typical trommel operating conditions at the plant (i.e., 7 to $13 \mathrm{Mg} / \mathrm{h}$ and $9 \mathrm{rpm}$ ), screening efficiencies in the range of 50 and $90 \%$ were measured. For feedrates near $14 \mathrm{Mg} / \mathrm{h}$, the measured efficiencies (50 to $70 \%$ ) are relatively low when compared to those typical of screening operations in general. To achieve screening efficiencies greater than $80 \%$, the maximum allowable feedrate should be approximately 7 to $9 \mathrm{Mg} / \mathrm{h}$.

The effect of rotational speed on screening efficiency also is illustrated in Figure 7.1; however, the trends are somewhat masked as a result of scatter in the data. Nevertheless, the data indicate that screening efficiencies generally increase with increases in rotational speed. As the reader will note from the data shown in Figure 7.1 , the differences in the levels of efficiency for each rotational speed are more discernible at the higher feedrates. The reason that screening efficiency increases with increased rotational speed is that bed depth decreases with increased rotational speed. The' effect of bed depth becomes more important as the feedrate is increased. Conversely, the effect of lifters (which are present in the Baltimore County trommel) is to mitigate the effect of rotational speed on screening efficiency, the reason being that irrespective of rotational speed, lifters tend to raise material to approximately the same point of detachment! from the screen surface.

It should be noted that the. "screening efficiency" parameter indicates the performance of a screen on the basis of the separation of particles according to particle size. This basis may or may not have a relation to the principal objective of the screening operation. Screening efficiency is not a direct measure of the performance of a screen in regard to the separation of material components in the feed or to the changing (improvement) of material properties of the separated streams (e.g., heating value of the oversize fraction). At the present time, the principal objective of trommel screening in resource recovery processing is rarely to separate materials according to size, but rather to separate material components or to increase the heating value and decrease the ash content of a separated fuel fraction. In light of the above remarks, additional parameters that quantify screening performance in terms of criteria other than size separation are presented in subsequent sections.

\subsection{ASH CONTENT AND MOISTURE CONTENT REMOVAL}

One of the major concerns in the preparation of refuse derived fuel (RDF) is the reduction of ash content in the fuel. Reducing the ash content is beneficial for a number of reasons, among them are: (a) a reduction in boiler slagging problems; (b) a reduction in ash handling and disposal 
problems at the power plant; and (c) an increase in the heating value of the fuel. Similarly, a reduction of the moisture content of the fuel will increase its heating value. Screening of a shredded and air classified feedstock results in an oversize fraction with an ash and moisture content that is lower than that of the feed because, in general, the undersize material has a higher ash content and a higher moisture content than that of the feedstock.

The ash content and moisture content of the Baltimore County oversize fractions are shown in Figure 7.2 for the various test runs:" The values are presented on an as-received basis. Both the ash content and the moisture content of the oversize material tend to increase as the feedrate increases. This effect is the result of increased retention of undersize material in the screen as the feedrate increases.

It should be noted that the ash content and the moisture content of the oversize material are functions of the ash content and the moisture content in the feed. Consequently, during the course of the study two parameters were developed to characterize the ash content and moisture content of the oversize fraction as a function of those of the trommel feedstock.

The two parameters, ash content removal (ACR) and moisture content removal (MCR) are defined below.

$$
A C R \equiv \frac{A C_{f}-A C_{0}}{A C_{f}} \times 100
$$

$$
\begin{aligned}
& \text { where, } \\
& A C_{f}=\text { ash content of the feed } \\
& A C_{0}=\text { ash content of the oversize fraction } \\
& \qquad M C R \equiv \frac{M C_{f}-M C_{0}}{M C_{f}} \times 100
\end{aligned}
$$

where,

$M C_{f}=$ muisture cuntent of the feed

$M C_{0}=$ moisture content of the overs

The weight bases for both definitions is as-received. 

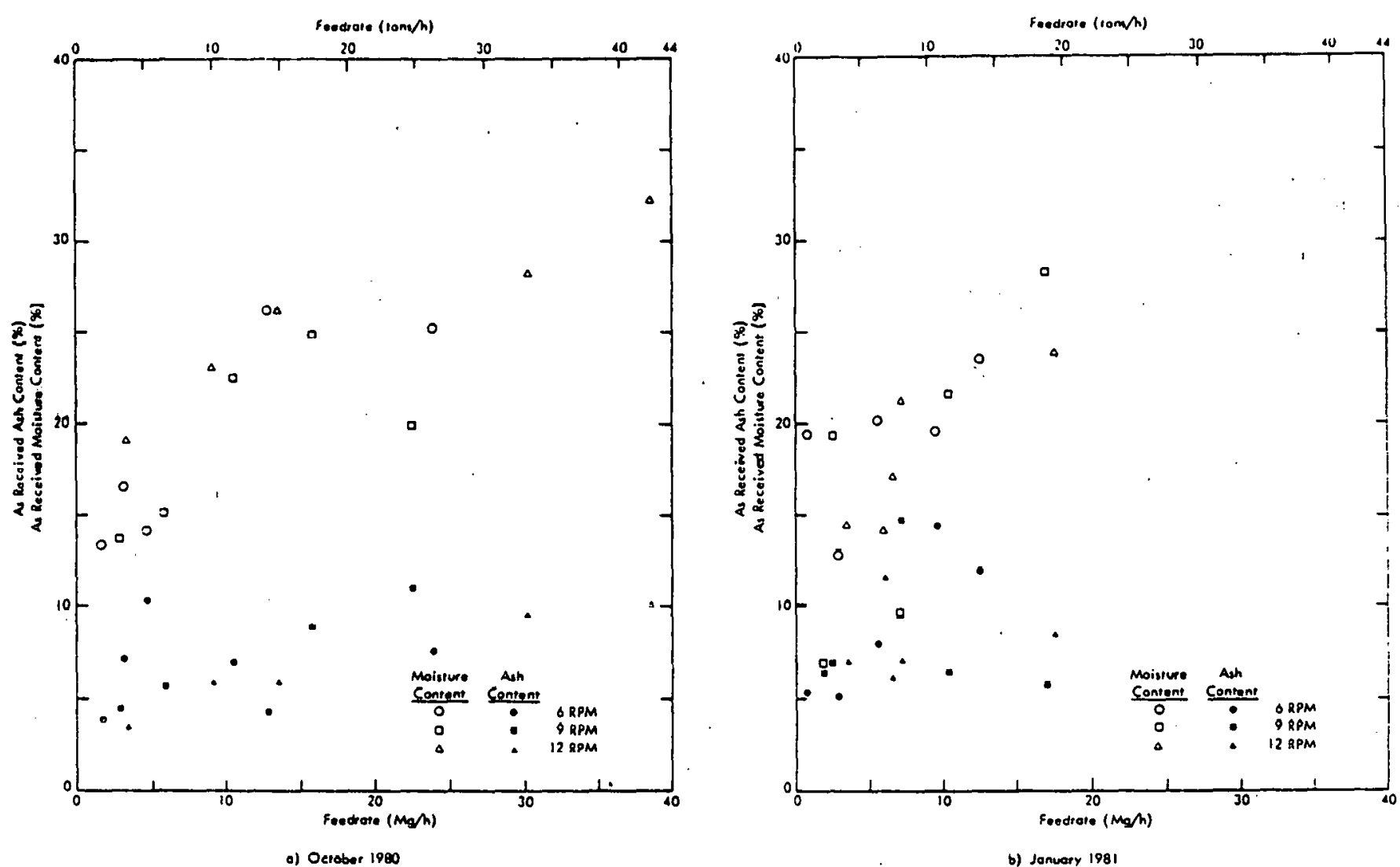

b) Jonwary 1981
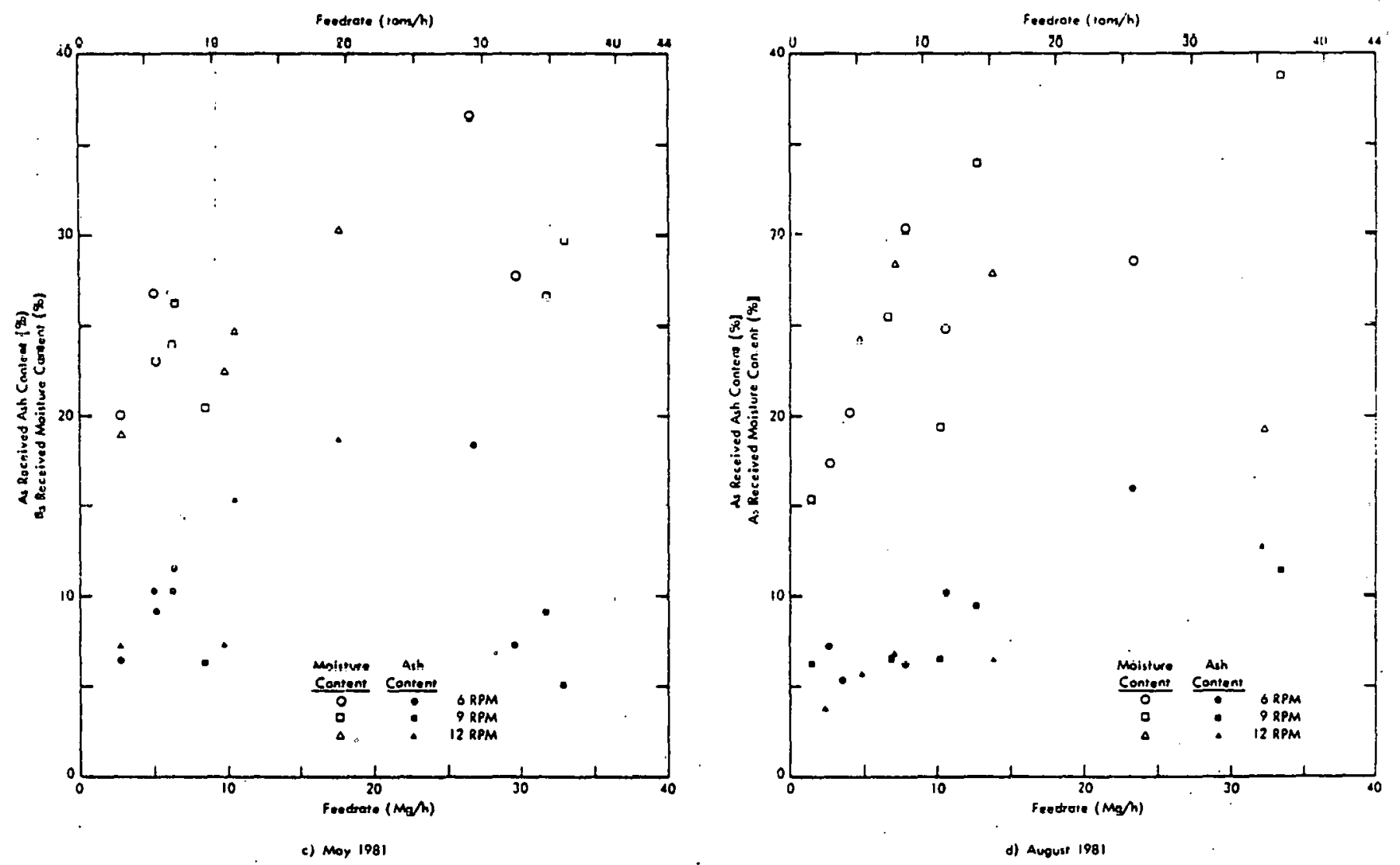

F1gure 7.2. Effect of Feedrate and Rotational Speed on Ash Content and Moisture Content of Oversize. 
The ash content removal and the moisture content removal are shown in Figure 7.3 for the various test runs. From the data, the decreasing trend for $M C R$ and $A C R$ can be discerned for increases in the feedrate. At the normal operating feedrates $(7$ to $13 \mathrm{Mg} / \mathrm{h}$ ) for the Baltimore County trommel, approximately 45 to $70 \%$ of the ash in the feed is removed and approximately 5 to $10 \%$ of the moisture in the feed is removed.

\subsection{ORGANIC CONTENT IMPROVEMENT AND ORGANIC RECOVERY}

One manner of characterizing the performance of a RDF system is to examine the effectiveness of the separation of the organic fraction of MSW from its inorganic constituents. Accordingly, the Baltimore County trommel serves to further refine and concentrate the organic fraction of air-classified light fraction produced at the plant. The purpose of increasing the organic content follows from the principal goals of increasing the heating value and decreasing the ash content of the fuel.

Based upon the component classifications used in this study, the organic quality of a particular waste fraction ( $Q$ ) is defined by the relation,

$$
Q \equiv \frac{W_{p p}+W_{o 0}}{W_{t}} \times 100
$$

where,

$Q=$ organic content and is expressed as a percentage

$W_{p p}=$ weight of "paper and plastic"

$W_{\text {oo }}=$ weight of "organic other" material

$W_{t}=$ total material

All weights being on an air-dry weight basis.

In order to evaluate the performance of the screen in terms of the organic content of the oversize fraction, two performance parameters are defined. Organic quality improvement indicates the percentage increase in the organic content of material in the oversize fraction when compared to that of the feed. Organic quality improvement, $I_{q}$, is defined by

$$
I_{q} \equiv \frac{Q_{t}}{Q_{f}} \times 100
$$

where,

$Q_{f}=$ organic contcnt of the feed expreesed as a percentage

$Q_{+}^{f}=$ organic content of the oversize fractions expressed as a percentage 

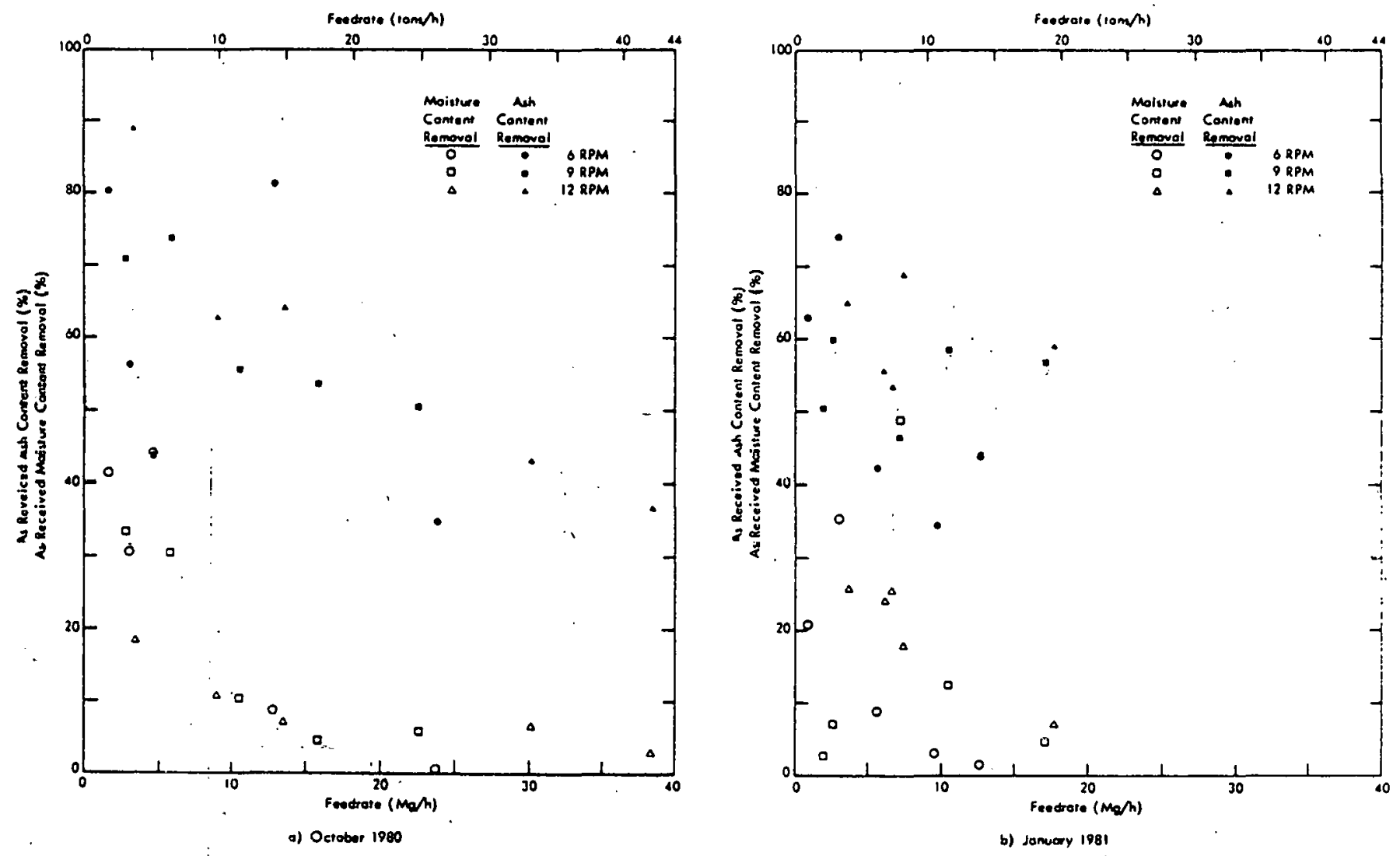

b) Jamuery 1881

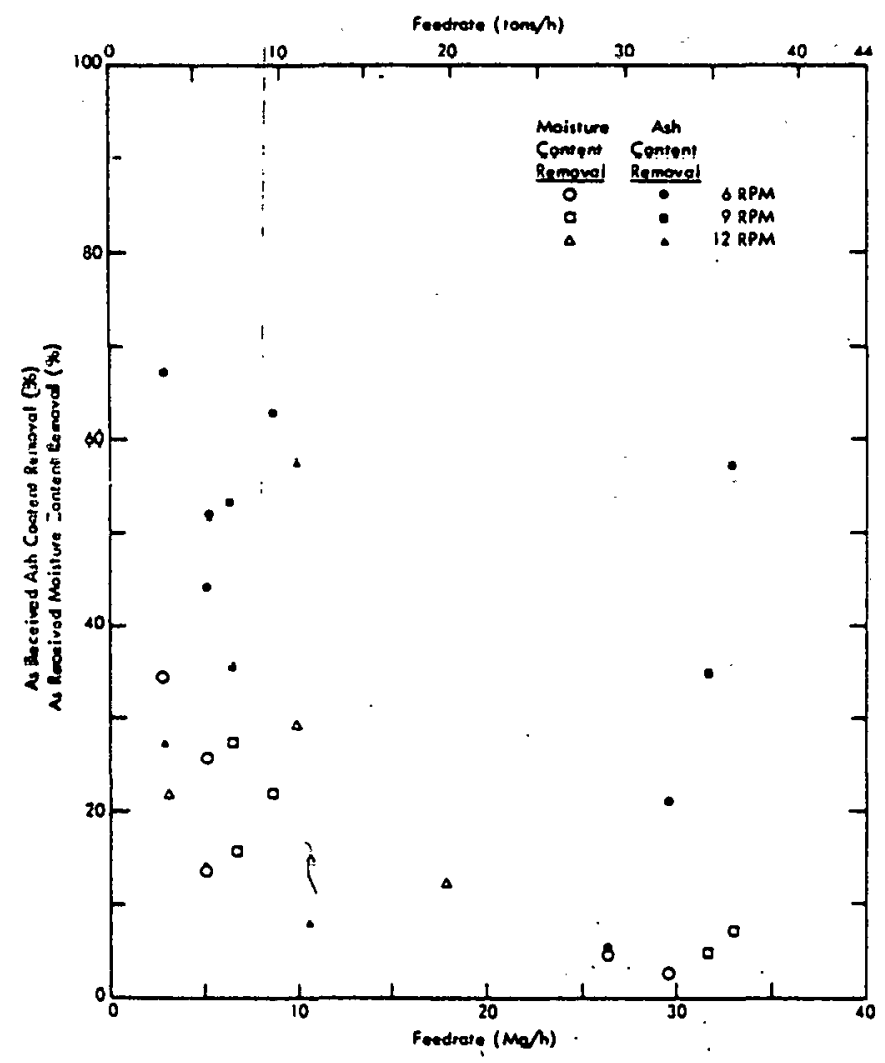

c) Mor 1981

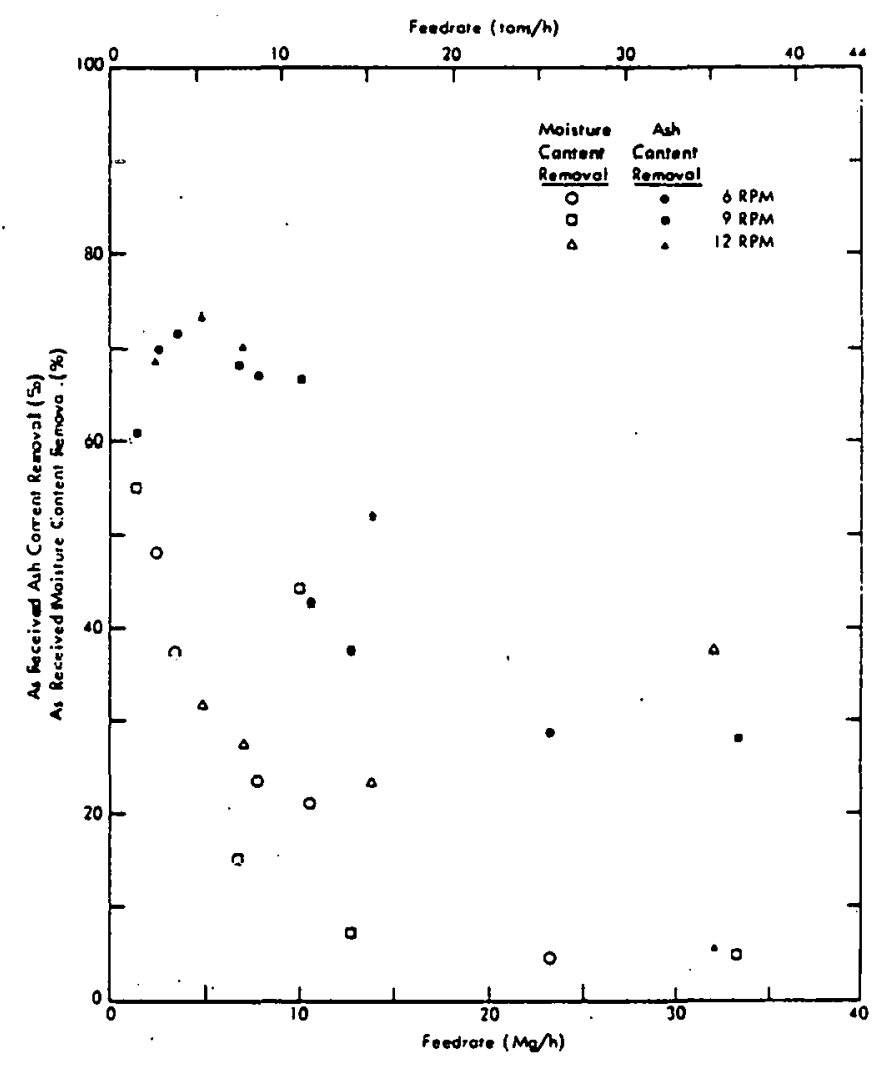

d) August 1981

Figure 7.3. Effect of Feedrate and Rotational Speed on Ash Content Removal and Moisture Content Removal. 
Organic recovery, $R_{0}$, indicates the percentage of organic material in the feed that is recovered in the oversize fraction. $R_{0}$ is defined by

$$
R_{0} \equiv m f+\frac{Q_{+}}{Q_{f}} \times 100
$$

where,

$\begin{aligned} & \mathrm{mf}_{+}= \text {mass fraction of oversize material expressed on an as-received } \\ & \text { weight basis }\end{aligned}$

Organic quality improvement and organic recovery for the various test runs are shown in Figure 7.4. The organic improvement factor decreases with increasing feedrate, while the recovery of organics increases and eventually plateaus as the feedrate is increased. The trends in the data indicate the tradeoffs that exist between improving the organic content of the fuel fraction and maximizing the recovery of organics. As may be noted from Figure 7.4 , for the range of normal operating feedrates for the Baltimore County trommel ( 7 to $13 \mathrm{Mg} / \mathrm{h}$ ), the organic quality improvement is approximately 120 to $130 \%$ and the recovery of organics is approximately 75 to $80 \%$.

\subsection{HEATING VALUE IMPROVEMENT AND ENERGY RECOVERY}

Heating value was also used as a means of characterizing the properties of the over- and undersize fractions and in the development of two performance parameters, namely, the heating value improvement factor and the energy yield. From heating value analyses performed on samples of oversize and undersize material obtained during the October 1980 and May 1981 tests, the effect of operational variables may be judged. For example, the heating values of the oversize fractions for the tests (shown in Figure 7.5) data indicate that as feedrate increases, the heating value of the oversize fraction decreases. In the range of normal operating feedrates for the trommel ( 7 to $13 \mathrm{Mg} / \mathrm{h}$ ), the heating value of the oversize fraction is approximately 15,000 to $17,000 \mathrm{~kJ} / \mathrm{kg}$ (approximately 6,500 to 7,300 Btu/lb), expressed on an as-received moisture basis.

Invoking the concepts of heating value improvement, $I_{h v}$, and energy recovery, $R_{e}$, and defining them similarly to organic improvement and organic recovery but in terms of heating value, results in the following definitions. 

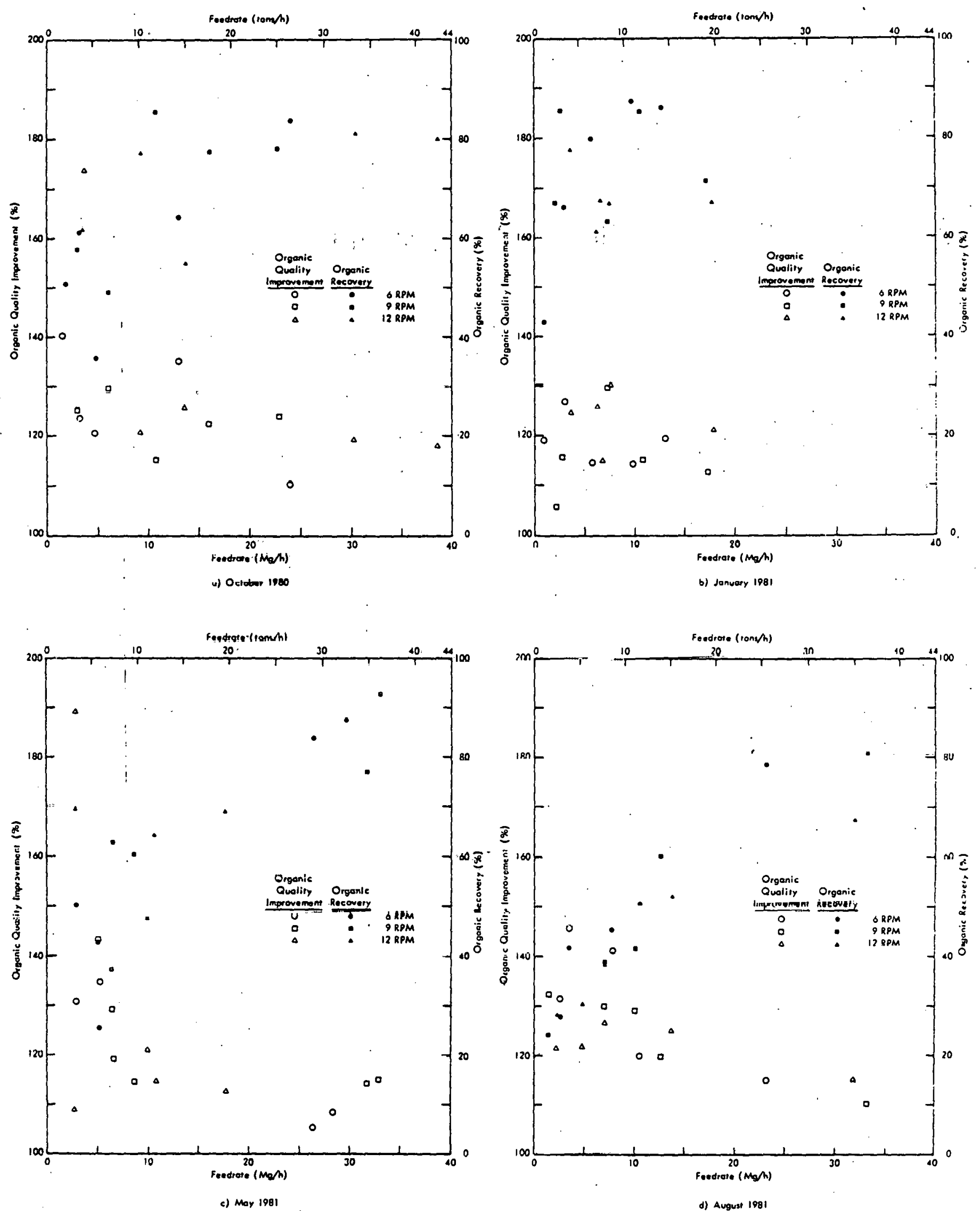

Figure 7.4. Effect of Feedrate and Rotational Speed on Organic

Quality Improvement and Organic Recovery. 


$$
I_{h v} \equiv \frac{H V_{t}}{\mathrm{HV}_{\mathrm{f}}} \times 100
$$

where,

$H V_{f}=$ heating value of the feed

$\mathrm{HV}_{+}=$heating value of the oversize fraction on an as-received weight basis)

and,

$$
R_{e}=m f_{+} \frac{I V_{t}}{H V_{f}} \times 100
$$

\footnotetext{
where,

$\mathrm{mf}_{+}=$mass fraction of the oversize material expressed on an as-received weight: basis
}

Heating value improvement identifies the improvement in the heating value of the oversize material in terms of a percentage of the feedstock heating value and equals $100 \%$ if the heating values of both fractions are identical.

Heating value improvement and the energy yield are shown in Figure 7.6 for the test runs in which heating values were measured. Similar to the results obtained for parameters utilizing organic content, heating value improvement decreases with increases in the feedrate and the energy recovery ratio increases with increases in the feedrate. A greater mass fraction of the feed is recovered in the oversize fraction at high feedrates due to the poor screening efficiency and the concomitant retention of undersize organic material. However, a greater proportion of undersize inorganic material is also retained, thus increasing the ash content of the fuel (see Figure 7.3).

The ash production per unit energy of fuel for the test runs is shown in Figurc 7.7. This parameter is an indication of both the ash content and the heating value of the fuel. As shown by the data in the figure, the ash production per unit energy increases with increasing feedrate. According to the results of the October 1980 tests, the ash production per unit energy is approximately 3 to $6 \mathrm{~kg}$ ash/GJ (approximately 7 to $12 \mathrm{lb}$ ash/MMBu) in the range of normal operating feedxates for the trommel. Substantial scatter in the results of the May 1981 tests makes estimations of this parameter difficult for that test period. 


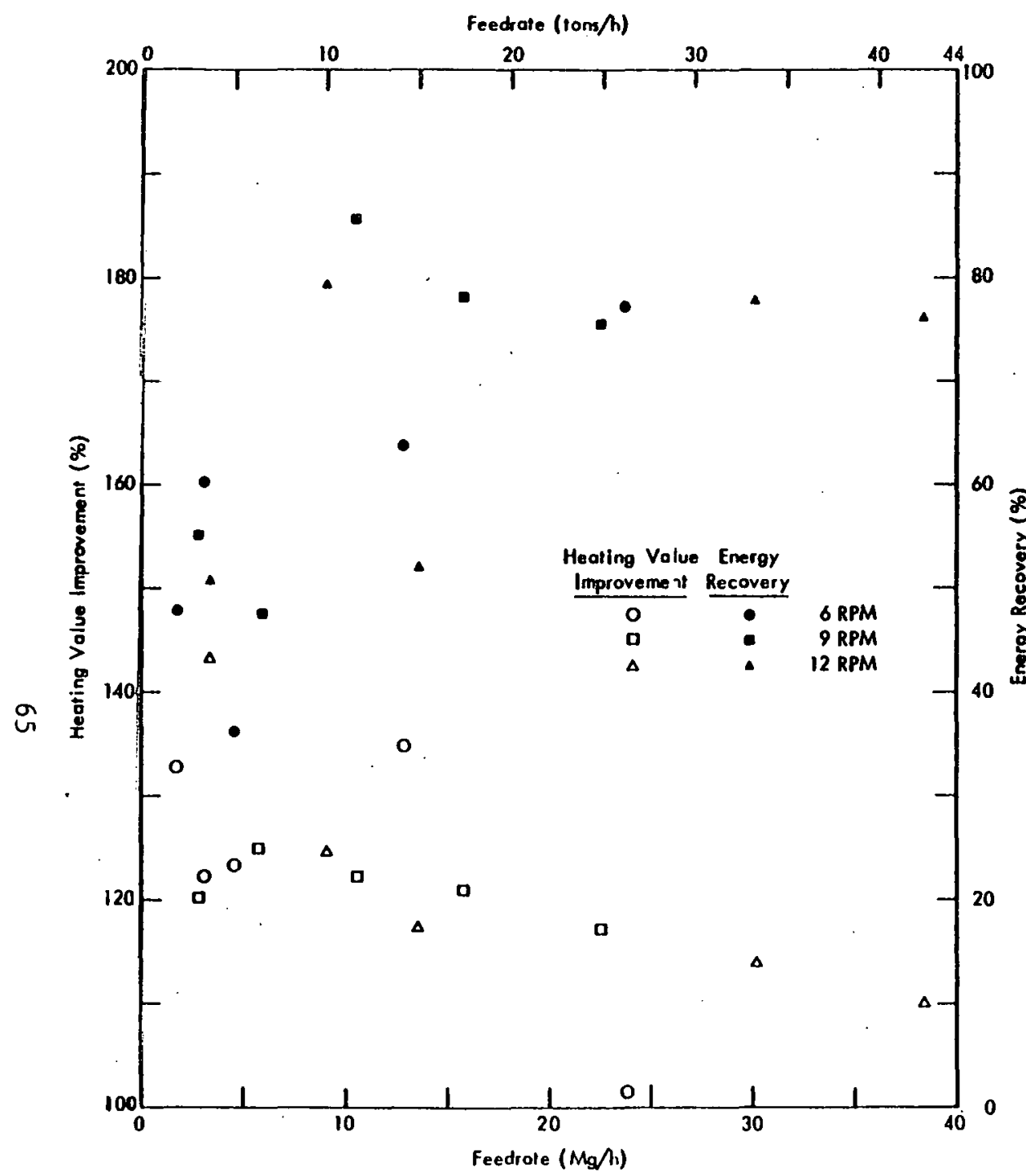

o) Ociober 1980

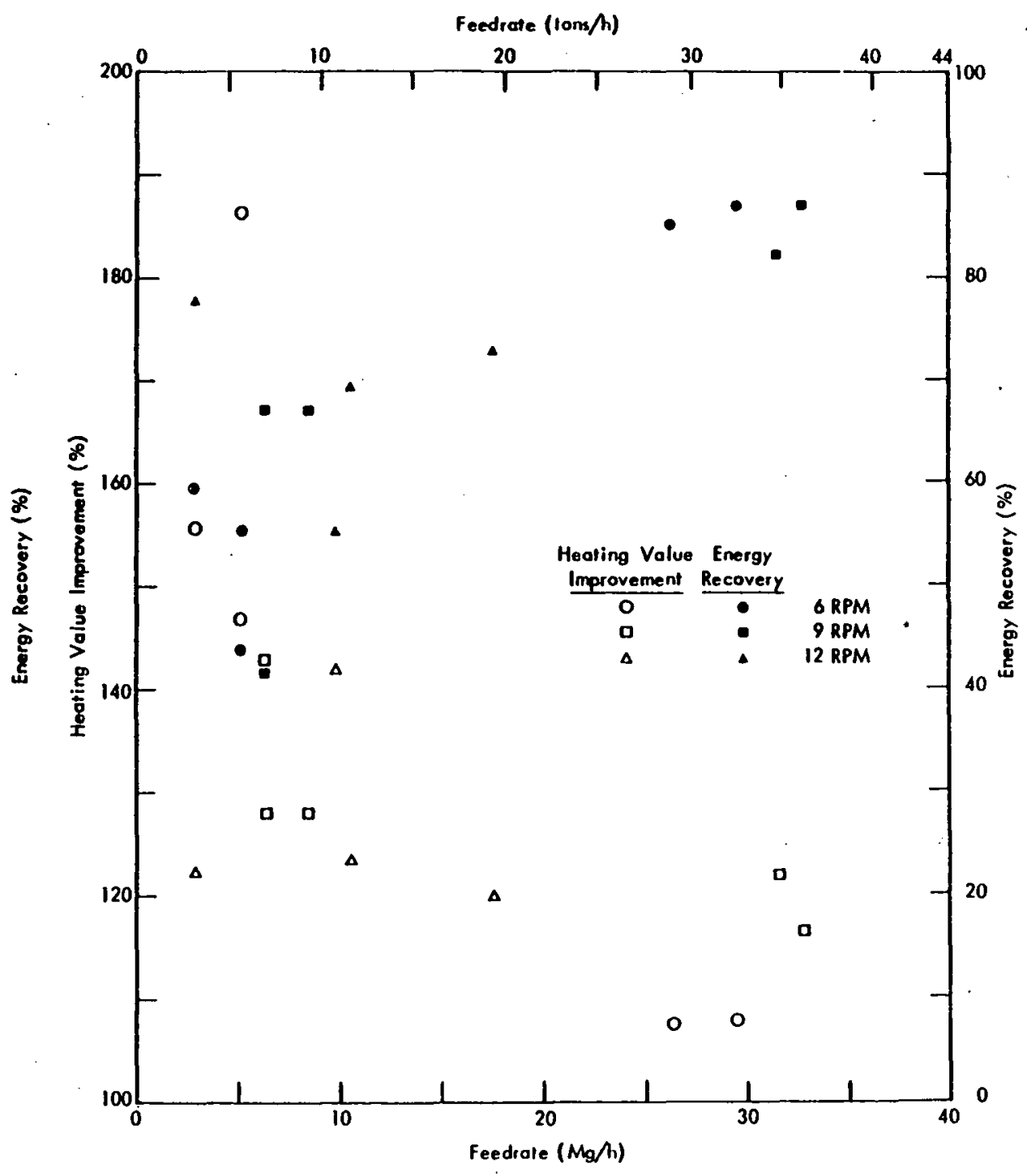

b) May 1981

Figure 7.6. Effect of Feedrate and Rotational Speed on Heating Value Improvement and Energy Recovery. 


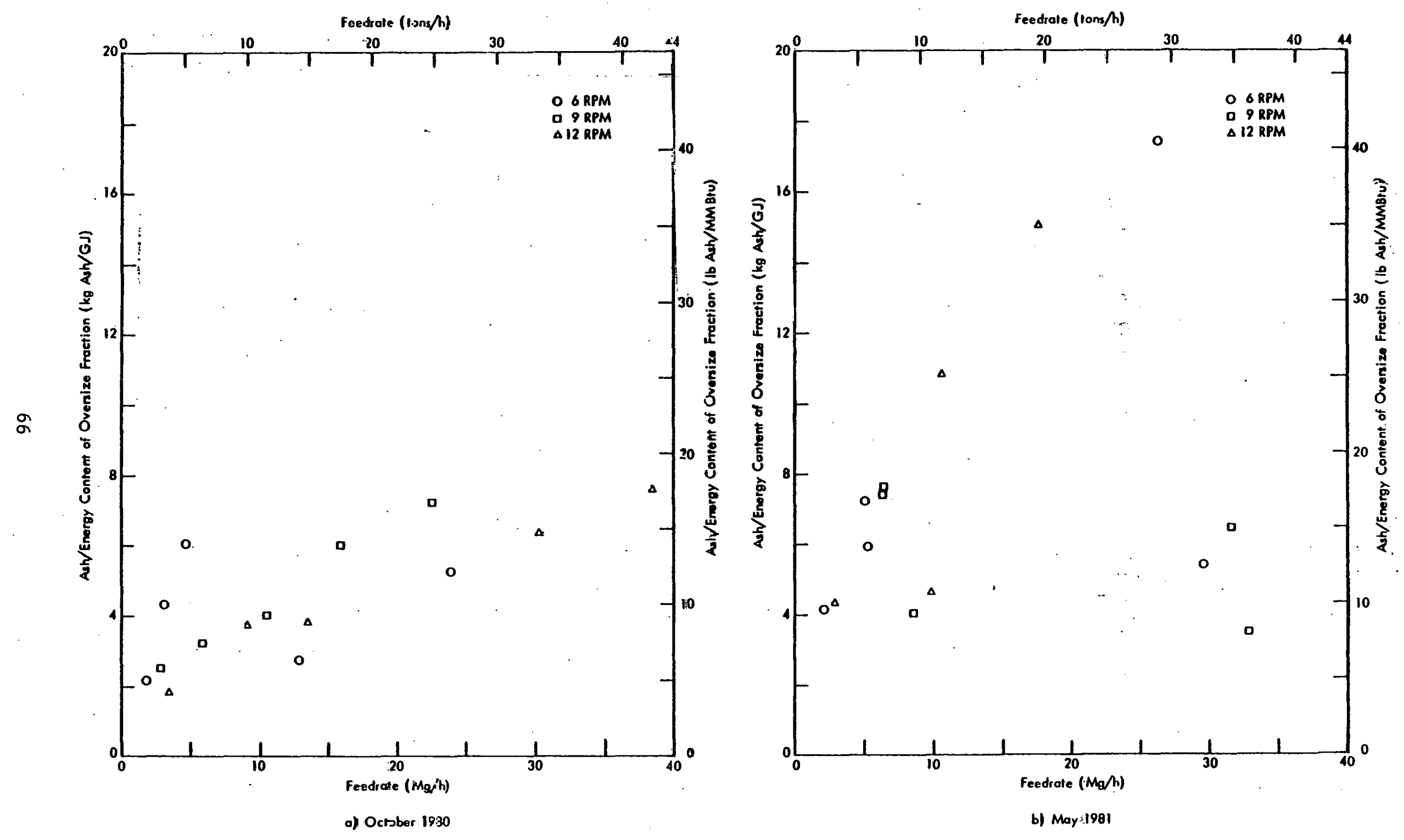

Figure 7.7. Effect of Feedrate and Rotational Speed on Ash Production Per Unit...Energy. 
Although the heating value provides a better description of fuel value than does organic content in terms of energy content, few processing plants have the capability of measuring heating value. Thus, the value of performance parameters based on organic content lies in the fact that screening performance can be evaluated by means of a component/size distribution analysis, rather than by employing bomb calorimetry and its rigorous test protocol. The utility of using organic content is exemplified by an inspection of Figures 7.4 and 7.6 in which are indicated similar trends for both the organic content and the heating value as a function of feedrate. As further evidence of their compatibility and interchangeability, Figure 7.8 has been constructed to illustrate the relationship between heating value and organic content of feed and oversize fractions.

The data in the figure show that as a first order approximation the heating value is linearly proportional to the organic content.

\subsection{TROMML ENERGY REQUIREMENTS}

As shown in Figure 7.9 , the energy requirements of the trommel motor per weight of infeed decreases rapidly as the infeed rate is increased. These data are from the first test series (October 1980) and are representative of all test series.

The data in Appendix $C$ indicate that power requirements were in the range of 2.3 to $6.6 \mathrm{~kW}$ over the range of measured feedrates ( 1 to $46 \mathrm{Mg} / \mathrm{h}$ ) while the specific energy requirements were in the range of 0.1 to 3.8 $\mathrm{kWh} / \mathrm{Mg}$. It may be gleaned from the power and throughput entries that power draw for the Baltimore trommel is not a strong function of throughput.

\subsection{COMPONENT AND SIZE DISTRIBUTION}

The previous discussions have shown that the trommel improves organic content and reduces ash content, which results from the fact that most of the noncombustibles are smaller than the $32-\mathrm{mm}(1-1 / 4-i n$.$) round trommel$ screen opening. The tables presented in Appendix B list the component and size distributions of the feed, oversize, and undersize flow streams for each test run. The data in these tables are the basis for the calculations of the screening performance parameters such as screening efficiency, organic quality improvement, organic recovery, etc.

Because the infeed to the trommel has been passed over a magnetic separator and then air classified before it reaches the trommel, the infeed does not contain appreciable quantities of metal. Glass, inorganic other, and fines are the major categories of noncombustible items. Fines are materials smaller than $1.3 \mathrm{~mm}$ and, thus, too small for accurate visual identification of components. The fines are mostly a grit material which is assumed tu be mainly noncombustible.

Inspection of Appendix B tables indicates that material in the glass and inorganic other categories is almost always smaller than $16 \mathrm{~mm}$ ( $5 / 8$ in.). Occasionally, small percentages are found in larger size classes, but the large majority is always smaller than $16 \mathrm{~mm}$ ( $5 / 8 \mathrm{in.}$ ), whether the sample is of the feed, overs, or unders flow streams. 


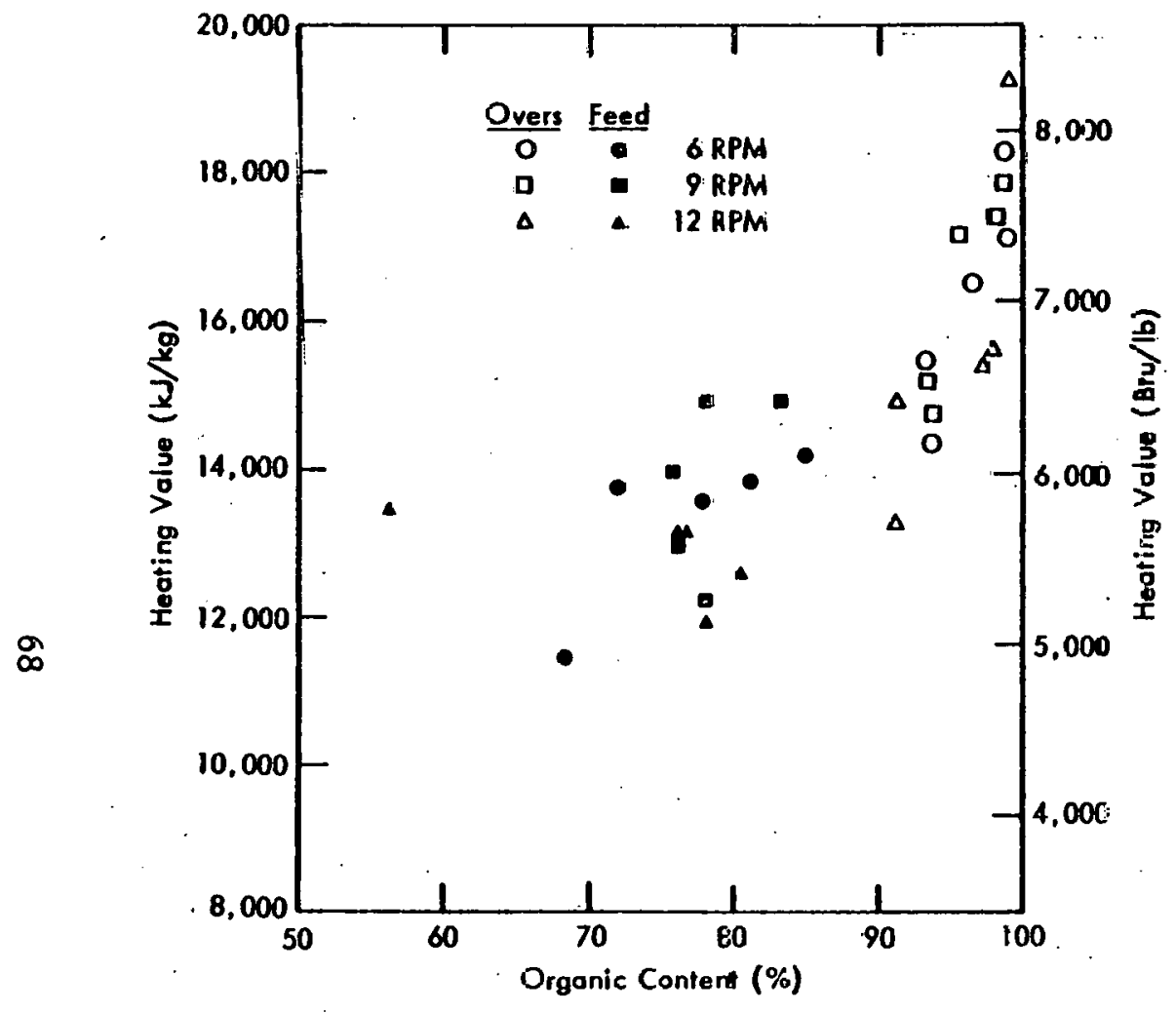

a) Octaber 1980

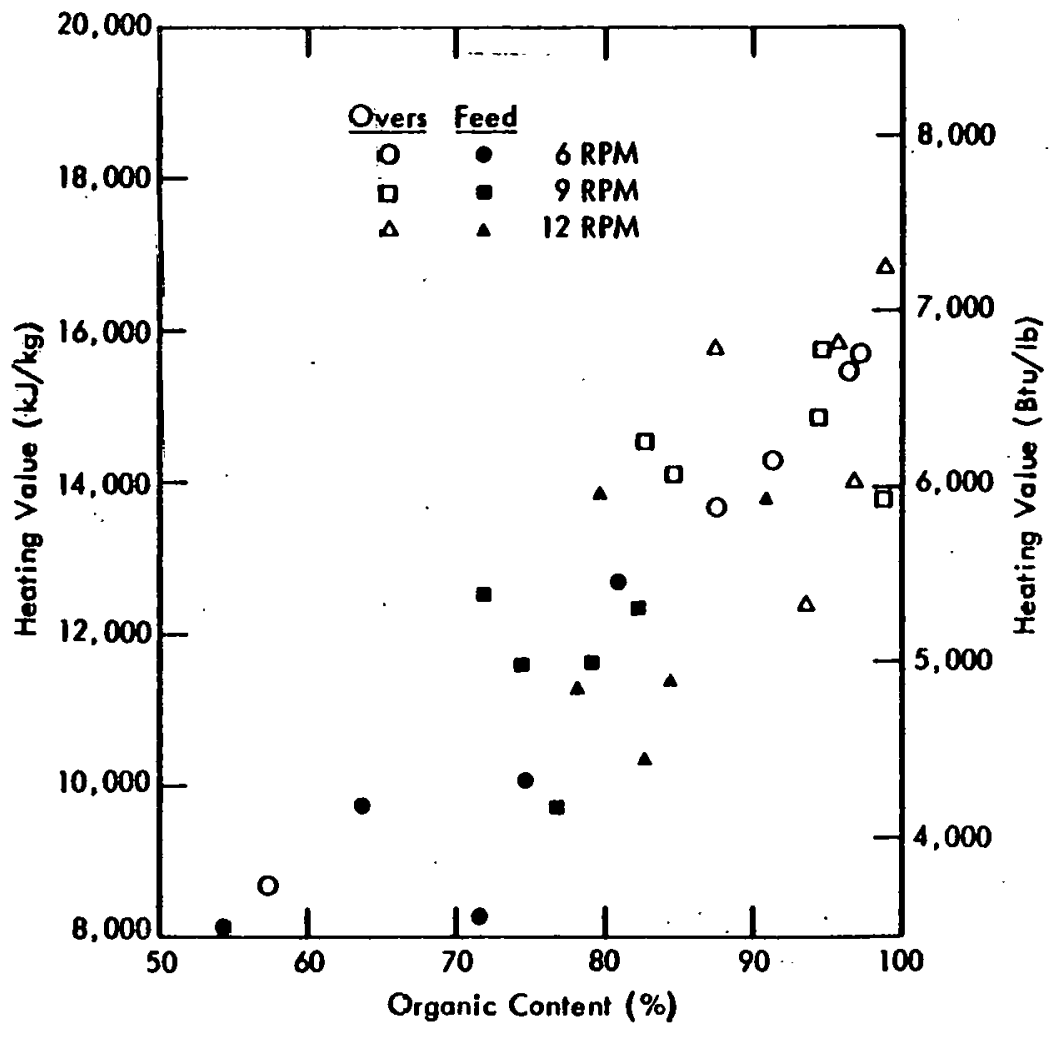

b) May 1981

Figure 7.8. Comparison of Heating Value and Organic Content. 


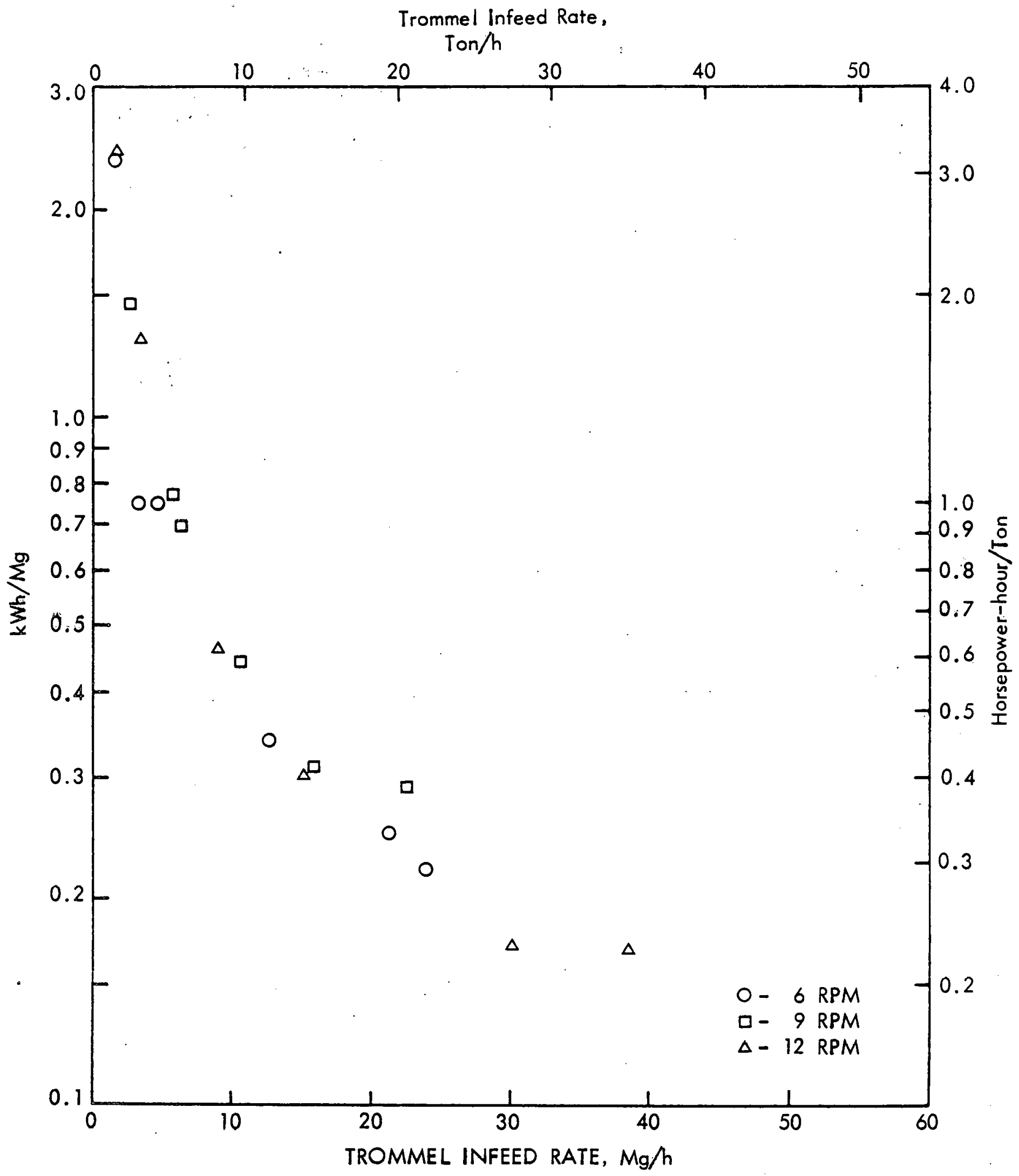

Figure 7.9. Trommel Energy Requirements Versus Infeed Rate. 
Unfortunately, the combustible materials of paper and plastic and organic other are distributed throughout the particle size range and also occur within the size fractions of glass and inorganic other. Consequently, removal, by screening, of the noncombustibles that are mainly less than $16 \mathrm{~mm}$ also result in removal of combustible materials. The tradeoff between removal of noncombustibles and recovery of combustibles is, of course, the primary consideration in the design selection of the screen aperture size. Optimum screen aperture size can be estimated for specified trommel performance if $100 \%$ screening efficiency is assumed. However, theoretical predictions of screening performance parameters quickly become very complex when screening inefficiencies are considered. Ultimately, the market demand for the fuel produced may be the overriding factor in aperture size selection. For example, when the market demand for $R D$ is only a small fraction of the RDF production capacity, then a very largc aperture size may be selected to insure a very high quality fuel. The low recovery in such a case is of no concern.

\subsection{BULK DENSITY}

Bulk density measurements were made of the oversize and undersize samples. Bulk density of the oversize ranged from 25.6 to $110.7 \mathrm{~kg} / \mathrm{m}^{3}$ ( 1.6 to $\left.6.9 \mathrm{Ib} / \mathrm{ft}^{3}\right)$ and that of the undersize ranged from 65.0 to $244.8 \mathrm{~kg} / \mathrm{m}^{3}(4.1$ to $\left.15.3 \mathrm{lb} / \mathrm{ft}^{3}\right)$. For any given test, the undersize bulk density was always greater than the oversize because the higher ash content undersize that was removed contained higher density materials. The particular bulk density of the oversize depends on the bulk density of the infeed and how much screening is achieved. Within the 7 to $13 \mathrm{Mg} / \mathrm{h}$ normal infeed range, the oversize bulk density ranges from 30.7 to $110.7 \mathrm{~kg} / \mathrm{m}^{3}\left(1.9\right.$ to $\left.6.9 \mathrm{lb} / \mathrm{ft}^{3}\right)$ and the undersize from 105.1 to $232.0 \mathrm{~kg} / \mathrm{m}^{3}\left(6.6\right.$ to $\left.14.5 \mathrm{lb} / \mathrm{ft}^{3}\right)$. The significance of these data is that regardless of trommel performance there is a wide variation in bulk density that the design of materials handling equipment must take into account when designing equipment such as conveyors. 


\section{E ECONOMIC ANALYSIS}

\subsection{CAPITAL COSTS}

\subsubsection{Conversion to Current Dollars}

Plans for constructing the Baltimore County Plant were made in 1973, and construction took place during 1974 and 1975. Shredding and ferrous metal recovery operations commenced in January 1976. The base year for calculating current dollar capital costs is 1974. While some construction operations continued in 1975,1974 was the year that agreements were established for the construction and for the purchase and installation of the majority of the equipment.

Chemical Engineering's Plant Cost Index has been used to convert from 1974 to 1981 dollars. ${ }^{4}$ The year 1981 is used as the most recent full year.

The Chemical Engineering index is a widely accepted published index of the increasing costs of building industrial plants. The Plant Cost Index includes equipment, fabricated machinery, supports, construction and engineering labor, building and materials, and supervision. Thus, it is the general index that best fits the Baltimore plant. Other indexes, such as the Marshall and Swift Equipment Cost Index, are available but are not more definitive for resource recovery plants.

The Chemical Engineering Magazine index is the following.

\begin{tabular}{l} 
Year $\quad$ (years $1957-1959=100$ ) \\
\hline
\end{tabular}

1974

1975

1976

1977

1978

1979

1980

1981
165.4

182.4

192.1

204.1

218.8

238.7

261.1

297.0
Multiplier

to year 1981

1.80

1.63

1.55

1.46

1.36

1.24

1.14

1. 0

The calculation of the multiplier for converting from one year to another is shown in the following example for 1974 to 1981 . 


$$
\begin{aligned}
\text { Multiplier } & =1+\frac{1981 \text { index }- \text { year installed index }}{\text { year installed index }} \\
& =1+\frac{297.0-165.4}{165.4}=1.80
\end{aligned}
$$

\subsubsection{Total Plant Cost}

The original 1974 plant cost was $\$ 8.4$ million followed by $\$ 1,048,719$ of equipment installed from 1975 through 1978, bringing the total plant cost to $\$ 9.4$ million. The equivalent 1981 dollar cost (Table $8: 1$ ) is $\$ 16.7 \mathrm{mil-}$ lion. All equipment costs reported are installed costs.

The trommel screen installation was $\$ 35,000$ in 1976 , which is equivalent to $\$ 54,300$ in 1981 . While the physical size of Lle trommcl $(3.7 \mathrm{~m}$ diameter by $8.0 \mathrm{~m}$ length) is significant, its installation at Baltimore was no problem, as the RDF facility building had sufficient head room and floor space to accommodate the trommel.

Capital cost of the trommel is a minor part of the total plant. In terms of 1981 dollars, the $\$ 53,300$ trommel cost is only $0.3 \%$ of the total plant and $3.6 \%$ of the $\$ 1.5$ million RDF facility. Thus, the trommel is not a major expense compared to the rest of the plant equipment.

\subsection{OPERATING AND MAINTENANCE COSTS}

\subsubsection{Operating Costs}

8.2.1.1 Labor and Overhead--

Operating costs for the trommel. Include operation and supervision labor, indirect costs, and electric power. There are no trommel operators as such, and inclusion of the trommel does not increase the labor hours for op-. eration or supervision. However, the Lrumel is a part of the plant and a portion of the operation and supervision labor as well as other indirect costs should be assigned to the trommel operation. This is best done on a percentage of capital cost basis. Table 8.1 shows that in 1981 dollars the trommel cost of $\$ 54,300$ is $3.55 \%$ of the total RDF facility cost. Labor costs for the total $\mathrm{RDF}$ plant and the perceutage asignment to the trommel are as follows. 
TABLE 8.1 INSTALLED CAPITAL COSTS OF BALTIMORE COUNTY RESOURCE RECOVERY FACILITY

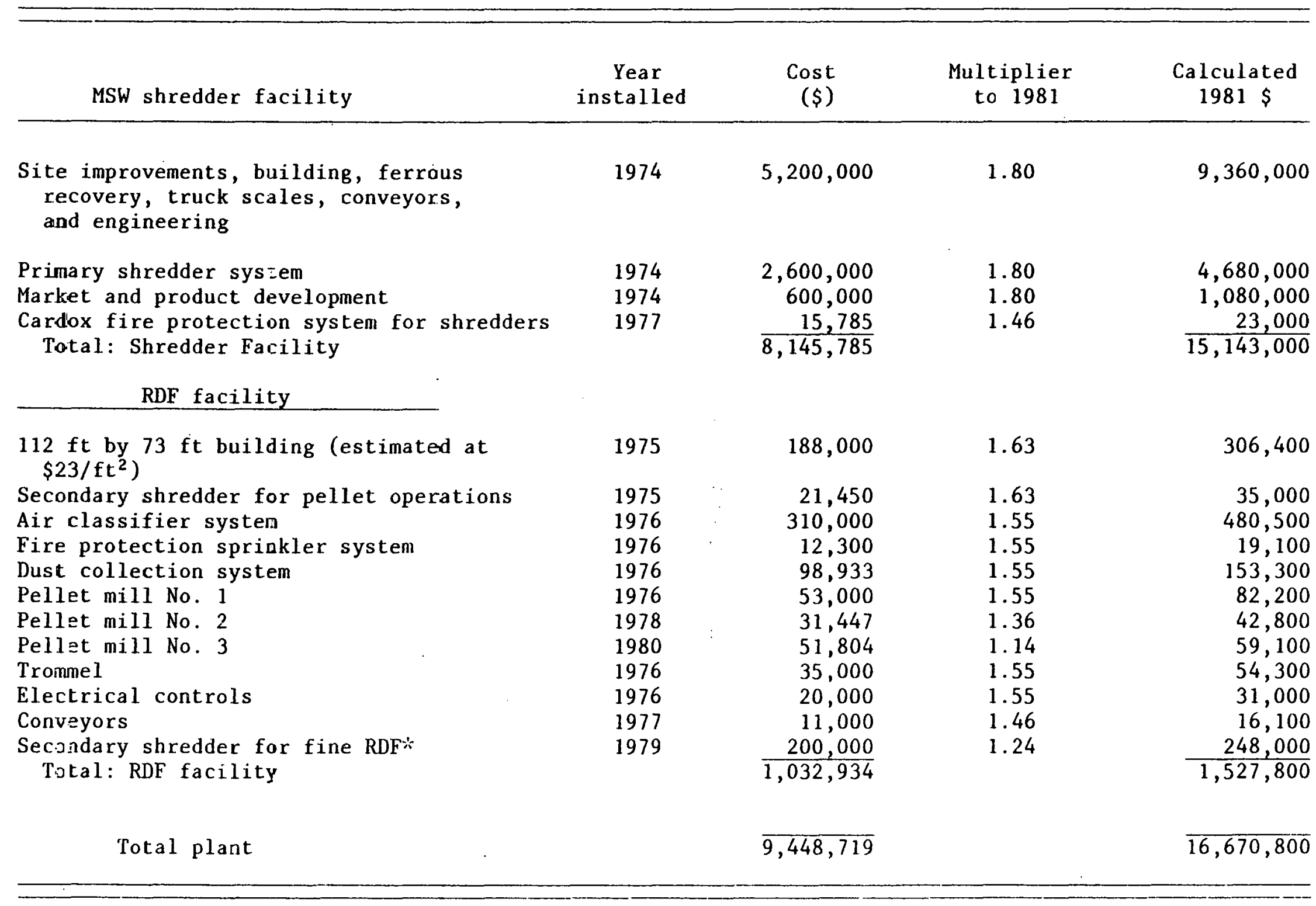

$\therefore$ This shredder not part of dRDF pellet operation. 
$\underline{\mathrm{RDF} \text { facility labor cost }}$

Operating labor

Maintenance labor

All indirect costs including supervision, administration, clerical, fringe benefits, and overhead costs (insurance, etc.)

\begin{tabular}{cc}
$\begin{array}{c}\text { Total for } \\
\text { year } \\
(\$)\end{array}$ & $\begin{array}{r}\text { Trommel } \\
\text { at } 3.55 \% \\
(\$)\end{array}$ \\
\hline $\begin{array}{l}59,215 \\
66,322\end{array}$ & $\begin{array}{r}2,102 \\
0\end{array}$ \\
112,537 & $\underline{3,995}$ \\
Total & $\$ 6,097$
\end{tabular}

Maintenance labor is not assigned to the trommel on a percentage basis because when the trommel required maintenance, labor hours associated with this work were recorded. This is discussed in Section 8.2.2.

\subsubsection{Electric Power--}

During the 12-month evaluation period of November 1980 through October 1981 , the trommel. operated for $2,906.1 \mathrm{~h}$. Trommel motor power requirements were measured during the four test periods and averaged $4.14 \mathrm{~kW}$ at the low.est flow rates tested at $6 \mathrm{rpm}$ rotational speed, which approximates the actual yearly trommel operation. Average electrical energy costs at the Baltimore plant were $\$ 0.035 / \mathrm{kW}-\mathrm{h}$. Cost of electric power for the year is:

$$
(2,906.1 \mathrm{~h}) \quad(4.14 \mathrm{~kW}) \quad(\$ 0.035 / \mathrm{kWh})=\$ 421
$$

\subsubsection{Maintenance Costs}

A log of the daily maintenance during the 1-year evaluation period is displayed in Appendix Table D-1. Table 8.2 is a summary of the maintenance by month. Maintenance required $312 \mathrm{~h}$ of plant labor costing $\$ 2,449 ; \$ 500$ for general plant supplies such as lubrication welding supplies, repair parts; $\$ 1,960$ for a new drive wheel and clutch assembly; and $\$ 12,600$ for an outside contractor to install. a new drive ring.

Major maintenance problems were the lifter bars inside the trommel, the drive wheel, and the carrier ring. The trommel is designed with steel bars welded to the interior surface of the trommel to help lift and move the shredded refuse through the trommel. These bars become loose and must be rewelded from time to time, which accounts for most of the welding in January through March. Power to rotate the trommel is transmitted by a steel drive wheel in contact with a steel carrier ring around the outside of the trommel. The drive wheel becomes loose and must be periodically reallgned and righeened. A new drive wheel assembly was installed in February. The carrier ring work hardened and finally had to be replaced in April 1981, which was the first carrier ring replacement since the trommel was installed in 1976. Installation of the new drive wheel and carrier ring had a major impact on maintenance costs: Maintenance labor hours through April and after April are as follows. 


\section{TABLE 8.2. MONTHLY TROMMEL MAINTENANCE}

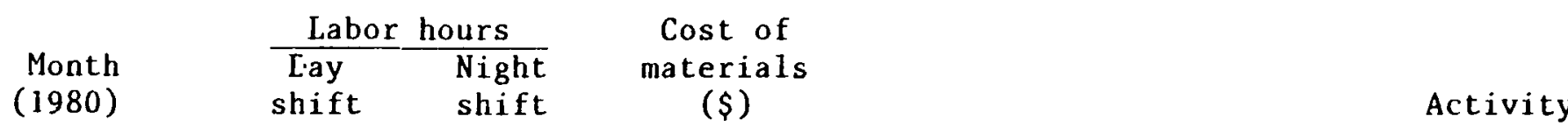

\begin{tabular}{|c|c|c|c|c|}
\hline Novenber & 0 & 16. & $\therefore$ & Lubrication; clean drive wheel. \\
\hline December & D & 20.5 & * & Lubrication; install new set screws on loose drive wheel. \\
\hline \multicolumn{5}{|l|}{$(1981)$} \\
\hline January & 5 & 39 & $\div$ & $\begin{array}{l}\text { Lubrication; replace worn drive wheel and support wheel, } \\
\text { weld broken lifter bars, screen, and carrier }\end{array}$ \\
\hline \multirow{2}{*}{ February } & ó & 15.5 & $\%$ & $\begin{array}{l}\text { ring. } \\
\text { Weld broken lifter bar, drive wheel and stop plate. }\end{array}$ \\
\hline & & & 1,960 & Install new drive wheel assembly and new clutches. \\
\hline March & 30 & 93 & $*$ & $\begin{array}{l}\text { Weld broken carrier ring and screen. Fabricate and in- } \\
\text { stall } 1 / 2 \text {-in. steel plate structural supports inside }\end{array}$ \\
\hline \multirow[t]{2}{*}{ April } & $2 ?$ & 43 & $\therefore$ & Same as March. \\
\hline & & & 12,600 & $\begin{array}{l}\text { New carrier ring fabricated and installed by outside } \\
\text { contractor. }\end{array}$ \\
\hline May & 0 & 1 & $*$ & Lubrication. \\
\hline June & 0 & 0 & & \\
\hline July & 0 & 5 & $*$ & Lubrication. \\
\hline August & 0 & 0 & & \\
\hline September & 0 & 0 & & \\
\hline \multirow{3}{*}{$\begin{array}{l}\text { October } \\
\text { Total }\end{array}$} & $\underline{0}$ & 10 & & Lubrication; tighten drive chain. \\
\hline & 69 & 243 & 15,060 & \\
\hline & & & & $\begin{array}{ll}\text { Total cost: } & \text { Labor } 312 \mathrm{~h} \text { a } 7.85 / \mathrm{h} * \%= \\
& \begin{array}{l}\text { Materials } \\
\end{array} \\
& \frac{15,449}{\$ 17,509}\end{array}$ \\
\hline
\end{tabular}

$\therefore$ Total cost of grease, oil welding rod, steel plate, and misc. parts estimated at $\$ 500$.

$\therefore \quad \$ 7.85 / \mathrm{h}$ labor cost. Fringe benefits and overhead included in plant indirect cost category. 


\begin{tabular}{|c|c|c|c|}
\hline Time period & $\begin{array}{c}\text { Maintenance } \\
\text { hours } \\
\end{array}$ & $\begin{array}{c}\text { Trommel } \\
\text { operating } \\
\text { hours } \\
\end{array}$ & $\begin{array}{r}\text { Ratio } \\
\text { maintenance hours } \\
\text { to operating hours } \\
\end{array}$ \\
\hline November-April & 296 & $1,505.3$ & 0.20 \\
\hline \multirow[t]{2}{*}{ May-October } & 16 & $1,400.2$ & 0.01 \\
\hline & 312 & $2,906.1$ & \\
\hline
\end{tabular}

Maintenance after April involved only lubrication and tightening a drive chain and trunnion wheel. In terms of maintenance labor required for operating hours, the installation of the new carrier ring resulted in a $95 \%$ reduction in maintenance labor.

The new drive wheel assembly and carrier ring replacement was the first such occurrence in the 5 years since operation began in 1976. If the test period had been in a year prior to 1981 , the $\$ 14,560 \operatorname{cost}(\$ 1,960$ ditive wheel plus $\$ 12,600$ carrier ring installation) would not have appeared. Therefore, the $\$ 14,560$ cost has been amortized over the 5 -year operating period using straight line amortization at $\$ 2,912$ per year. Maintenance labor is not amortized because the actual labor hours expended in installing the drive wheel assembly totaled only $11 \mathrm{~h}$, which $1 \mathrm{~s}$ relalively minor in comparison to the total 312 maintenance hours and labor for installation of the new carrier ring that was provided by an outside contractor. Total maintenance costs for the year are:

Maintenance labor: $312 \mathrm{~h}$ at $\$ 7.85 / \mathrm{h}$

Misc. repair parts and lubrication and welding supplies:

$\$ 2,449$

New drive assembly and carrier ring ( $\$ 14,560 \div 5$ years):

$\$ \frac{2,912}{5,861}$

The total out-of-pocket cost $(2,449+500+14,560)$ is $\$ 17,509$. However, the $\$ 5,861$ cost is a better value to use to derive a cost base for comparing trommel maintenance costs to other operations because the unusual cost of the drive and carrier ring is a cost that occurs only once per 5 years, based on experience to date.

\subsection{ANNUAL PRODUCTION}

\subsubsection{Operating Hours and Production}

The daily volume of product and the hours of operation are listed in Appendix Tables $\mathrm{D}-2$ and $\mathrm{D}-3$. During the 12 -month evaluation period, November 1980 through October 1981, the trommel operated 2,906 h over 267 days for an average of $10.9 \mathrm{~h} /$ day (Table 8.3). During the same period, 2,027 $\mathrm{Mg}$ of dRDF pellets were shipped to Wright Patterson Air Force Base. Operating hours were recorded by an hour meter connected to the trommel drive motor circuit. 
TABLE 8.3. MONTHLY OPERATION OF TROMMEL

\begin{tabular}{|c|c|c|c|c|}
\hline Month & $\begin{array}{l}\text { Days in } \\
\text { operation }\end{array}$ & $\begin{array}{l}\text { Hours in } \\
\text { operation }\end{array}$ & $\begin{array}{c}\text { Average } \\
\text { operation } \\
\text { (h/day) }\end{array}$ & $\begin{array}{c}\text { dRDF pellets } \\
\text { shipped } \\
(\mathrm{Mg})\end{array}$ \\
\hline \multicolumn{5}{|l|}{1980} \\
\hline November & 21 & 236.1 & 11.2 & 191.94 \\
\hline December & 20 & 153.8 & 7.7 & 0 \\
\hline \multicolumn{5}{|l|}{1981} \\
\hline$\overline{J a n u a r y}$ & 19 & 246.2 & 13.0 & 298.58 \\
\hline February & 23 & 300.3 & 13.1 & 321.72 \\
\hline March & 25 & 312.4 & 12.5 & 343.93 \\
\hline April & 19 & 256.5 & 13.5 & 134.22 \\
\hline May & 22 & 221.0 & 10.0 & 135.97 \\
\hline June & 23 & 148.3 & 6.4 & 0 \\
\hline July & 22 & 225.9 & 10.3 & 249.31 \\
\hline August & 24 & 252.3 & 10.5 & 0 \\
\hline September & 25 & 285.9 & 11.4 & 265.69 \\
\hline October & 24 & 267.4 & 11.1 & 85.28 \\
\hline \multirow[t]{2}{*}{ Total } & 267 & $2,906.1$ & 10.9 & $2,026.64$ \\
\hline & Average proce & ate $=\frac{2,02}{2,90}$ & $\frac{\mathrm{Mg}}{\mathrm{h}}=0.70$ & \\
\hline
\end{tabular}


Unfortunately, the plant design did not provide for weighing the material flow streams either to or from the trommel or pellet mills. The trommeled RDF was fed directly to the pelleting operation. The amount of dRDF pellets produced was weighed only when the pellets were shipped from the plant. While a record of operating hours exists, a correlation of operating hours to $\mathrm{Mg}$ of $\mathrm{dRDF}$ cannot be made to arrive at an $\mathrm{Mg} / \mathrm{h}$ value, except on a yearly basis. No $\mathrm{dRDF}$ pellets were in storage at the start of November or at the end of October, and the $2,027 \mathrm{Mg}$ is representative of the year's operation.

The annual average processing rate of $0.7 \mathrm{Mg} / \mathrm{h}$ is low in comparison to the trommel's capacity because of the pellet mill operation. During the 1-year evaluation period, there was not a market for RDF; therefore, shredded MSW was conveyed to the RDF facility only when there was a need to run the pellet operation and produce dRDF. The trommel was sized to handle up to $38 \mathrm{Mg} / \mathrm{h}$, which would provide $23 \mathrm{Mg} / \mathrm{h}$ to the pellet operation on the hasis of a split of $40 \%$ fines remover hy the tromel and $60 \%$ going to the sceondary shredder and pellet mill. However, the pellet mills used had serious problems with jamming. When this occurred, the shredded MSW fed to the RDF plant was shut off and the shredded MSW that would have gone to the RDF plant was added to the shredded MSW going to landfill. Because unjamming of the pellet mill was an operation that normally did not require a full day, the RDF plant equipment, including the trommel, was kept in operation so that once the pellet mill was unjammed, shredded MSW flow sonld commence and pelleting resume. Thus, the flow through the trommel could be started and stopped several times. during the day but the trommel kept rotating. The net result is that total operating hours are high and total material weight processed is low.

Plant personnel estimate that the pellet operations average less than $0.9 \mathrm{Mg} / \mathrm{h}$ ( 1 ton $/ \mathrm{h})$, which confirms the measured $0.7-\mathrm{Mg} / \mathrm{h}$ value. Actual instantaneous flow rates would, of course, be much higher herallse the annual rates include all the pellet mill downtime. Plant personnel estimate that when material is actually flowing through the trommel, the normal feedrate is 7 to $13 \mathrm{Mg} / \mathrm{h}$. Normal operating speed is $6 \mathrm{rpm}$, and the average percent of the infeed going to the pellet operation (oversize) at $6 \mathrm{rpm}$ and within this infeed range is $54.2 \%$, which is close to the nominal $60 \%$ over size split. assumed for the trommel. Therefore, the $0.7-\mathrm{Mg} / \mathrm{h}$ pellet feed converts to $1.3-\mathrm{Mg} / \mathrm{h}$ infeed to the trommel. Assuming an average instantaneous rate of $10 \mathrm{Mg} / \mathrm{h}$ (average 7 to $1.3 \mathrm{Mg} / \mathrm{h}$ ) t.rnmmel infeed rather than the annual $1.3 \mathrm{Mg} / \mathrm{h}$ rates indicates the trommel was running empty $87 \%$ of the time.

The plant day shift began at 7:00 a.m. and continued until 5:00 p.m., a total of $10 \mathrm{~h}$. Average operating hours were $10.9 \mathrm{~h} /$ day. Processing operations were not stopped during the lunch break, as the plant personnel took staggered lunch breaks. The trommel obviously was operated briefly during the evening maintenance shift $(5: 00 \mathrm{p} . \mathrm{m}$. to $1: 30 \mathrm{a} . \mathrm{m}$.$) , and there$ were several days when the trommel was operated during the night shift to meet the dRDF production requirements. 
For cost normalization purposes, the usual method is to express cost in terms of the weight of product produced as $\$ / \mathrm{Mg}$. As the above discussion shows, the amount of $\mathrm{dRDF}$ pellets produced is not indicative of the total trommel operation. For example, wear on the drive components is primarily a function of operating hours; therefore, operating hours must also be considered in any cost normalization calculations.

\subsubsection{Availability}

The trommel operated consistently over the year as indicated by the 267 days in operation and an average of over $10 \mathrm{~h} /$ day (Table 8.3). A comparison of trommel availability (Table 8.4) shows the trommel was available $97 \%$ of the work days compared to $89 \%$ for the balance of the RDF plant.

Analysis of the maintenance log (Appendix Table D-1) shows that the bulk of the maintenance was accomplished during the evening shift after 5:00 p.m.; thus, daily operation was not disturbed. For 9 days, maintenance was performed on the trommel during the full day shift, and this time is charged against the trommel as downtime. On two occasions, maintenance was performed on the trommel for 2 to $3 \mathrm{~h}$ during the day shift. In one case, the plant did not operate at all that day; in the other case, the plant did operate, so these days were not charged against the trommel. On one other day, trommel maintenance was done on a Sunday. This also was not charged as a trommel down day because the plant would not normally have operated on a Sunday. All nine trommel down days involved repair or replacement of the drive ring. Once this ring was replaced in April, no further down days occurred.

\subsection{TOTAL COST}

Total cost to operate the trommel is composed of the yearly depreciation value of the capital required to install the trommel and the operating and maintenance costs. A 10-year depreciation period is used as this is the IRS-recommended period for resource recovery plants. 5 The allowable IRS depreciation range is 8 to 12 years with 10 years as the recommended midpoint. A variety of depreciation formulas may be used, depending upon the particular circumstances involved. In this study of the trommel screen, straight line depreciation is used since it is the simplest formula, yielding $10 \%$ per year for 10 years. Plant operators with differenc depreciation schedules who wish to apply the trommel costs calculated in this report to their facilities can easily recalculate the yearly depreciation values. Total costs for the trommel, based on this 1-year study from November 1980 through October 1981, expressed in 1981 dollars, are: 
TABLE 8.4. TROMEL AND RDF. PLANT AVAILABILITY

\begin{tabular}{|c|c|c|c|c|c|}
\hline \multirow[b]{2}{*}{ Month } & \multirow[b]{2}{*}{$\begin{array}{l}\text { Days RDF plant } \\
\text { available for } \\
\text { operation* }\end{array}$} & \multicolumn{3}{|c|}{ Days downtime } & \multirow[b]{2}{*}{$\begin{array}{c}\text { Days } \\
\text { RDF plant } \\
\text { in operation }\end{array}$} \\
\hline & & Trommel & $\begin{array}{l}\text { Balance of } \\
\text { RDF plant }\end{array}$ & $\begin{array}{l}\text { Total } \\
\text { RDF } \\
\text { plant }\end{array}$ & \\
\hline \multicolumn{6}{|l|}{1980} \\
\hline November & 25 & 0 & 4 & 4 & 21 \\
\hline December & 26 & 0 & 6 & 6 & 20 \\
\hline \multicolumn{6}{|l|}{1981} \\
\hline$\overline{J a n u a r y}$ & 26 & 0 & 7 & 1 & 19 \\
\hline February & 24 & 0 & 1 & 1 & 23 \\
\hline March & 26 & 1 & - & 1 & 25 \\
\hline April & 26 & 8 & - & 8 & 18 \\
\hline May & 26 & 0 & 4 & 4 & 22 \\
\hline June & $25^{\circ}$ & 0 & 2 & 2 & 23 \\
\hline July & 26 & 0 & 4 & 4 & 22 \\
\hline August & 26. & 0 & 2 & 2 & 24 \\
\hline September & 25 & 0 & 0 & 0 & 25 \\
\hline October & 27 & $\underline{0}$ & 3 & 3 & 24 \\
\hline $\begin{array}{l}\text { Total Days } \\
\% \text { Availability }\end{array}$ & 308 & $\begin{array}{l}9 \\
97.1\end{array}$ & $\begin{array}{l}33 \\
89: 3\end{array}$ & $\begin{array}{l}42 \\
86.7\end{array}$ & 266 \\
\hline
\end{tabular}

* Includes Saturday and excludes Sundays and six holidays.

it: Availability:

Trommel $=\frac{\text { days trommel operated }}{\text { days available for trommel }}=\frac{\text { days trommel operated }}{\begin{array}{c}\text { plant available days-halanre of plant } \\ \text { downtime }\end{array}}$

$$
\%=\frac{266}{308-33} \times 100=96.7 \%
$$

Balance of RDF plant $=\frac{\text { days plant would have operated if not for trommel }}{\text { days available for plant }}$

$$
\begin{aligned}
& =\frac{\text { plant available days - balance of plant downtime }}{\text { plant available days }} \\
& \%=\frac{308-33}{308} \times 100=\underline{\underline{89.3 \%}}
\end{aligned}
$$

Total plant $=\frac{\text { days plant operated }}{\text { days available for plant }} \quad \%=\frac{266}{308} \times 100=86.4$ 


\section{$\underline{\text { Item }}$}

Capital depreciation ( $10 \%$ of $\$ 54,300)$
Yearly cost

\$ of Total

$5,430 \quad 30.5$
Operating costs

Direct operating labor

Supervision, clerical,

fringe benefits, overhead, 3,995

and all other indirect

costs

Electric power

Maintenance costs

Maintenance labor

Parts, supplies, and outside contractor

Total yearly cost
$\$ 2,102$

421

6,518

36.6

2,449

3,412 5,861

$\$ 1 \overline{7,809}$ $\frac{32.9}{100.0}$

The total $\$ 17,809$ annual cost is relatively evenly divided among the three categories of capital depreciation, operating costs, and maintenance costs.

The cost normalization ratios are:

Hourly cost $=\frac{\$ 17,809 \text { yearly cost }}{2,906.1 \text { annnual operating hours }}=\$ 6.13 / \mathrm{h}$

Produce cost $=\frac{\$ 17,809 \text { yearly cost }}{2,026.64 \mathrm{Mg} \mathrm{dRDF} \text { produced }}=\$ 8.79 / \mathrm{Mg}$ of $\mathrm{dRDF}$

Trommel infeed $=\frac{\$ 17,809 \text { yearly cost }}{\frac{2,026.64 \mathrm{Mg} \text { dRDF produced }}{0.542 \text { oversize split }}}=\$ 4.76 / \mathrm{Mg}$ of trommel infeed

The above $\$ / \mathrm{Mg}$ costs are higher than would have occurred had the pellet operation had a higher average flow rate. Also, if the trommel were being installed now to meet the known pellet system flow rate, a smaller trommel with resulting lower cost might be installed. In either case, the $\$ / \mathrm{Mg}$ cost would be lower.

Assuming that maintenance costs would not increase substantially with increased throughput, then a cost can be derived for trommel operating conditions with higher average flow rates. Trommel efficiency, ash and moisture removal, organic quality improvement, and heating value improvement 
tend to decrease with increasing flow rate. If the $10 \mathrm{Mg} / \mathrm{h}$ average instantaneous infeed rate is selected as a potential yearly rate, then yearly. costs would be:

Potential cost $=\frac{\$ 17,809 \text { yearly cost }}{(2,906.1 \text { operating } \mathrm{h})(10 \mathrm{Mg} / \mathrm{h})}=\$ 0.61 / \mathrm{Mg}$ of trommel infeed

of course, the trommel could be operated at much higher flow rates, thus reducing the $\$ / \mathrm{Mg}$ cost even more; however, the associated sacrifices in screening efficiency would probably be unacceptable. The $10 \mathrm{Mg} / \mathrm{h}$ is a more reasonable value to use for cost comparisons, as it is approximately the highest processing rate at which optimum product quality is achieved.

In terms of dRDF produced at $54.2 \%$ of the trommel infced, the abuve jutential processing rate yields $5.42 \mathrm{Mg} / \mathrm{h}$ of $\mathrm{dRDF}$ and the cost for dRDF is:

Potential cost $=\frac{\$ 17,809 \text { yearly cost }}{(2,906.1 \text { operating hours })(5.42 \mathrm{Mg} / \mathrm{h})}=\$ 1.13 / \mathrm{Mg}$ of $\mathrm{dRDF}$

The following comparison of these various ratios shows that while the trommel actual cost was $\$ 8.79 / \mathrm{Mg}$ of $\mathrm{dRDF}$ pellets produced, the tromel has the capability to achieve $\$ 1.13 / \mathrm{Mg}$ or lower of dRDF total cost.

\begin{tabular}{|c|c|c|c|}
\hline Flow rate & Unit & Actuall & Potential \\
\hline $\begin{array}{l}\text { Trommel Infeed } \\
\text { dRDF Produced }\end{array}$ & $\begin{array}{l}\mathrm{Mg} / \mathrm{h} \\
\mathrm{Mg} / \mathrm{h}\end{array}$ & $\begin{array}{l}1.3 \\
0.70\end{array}$ & $\begin{array}{r}10 \\
5.42\end{array}$ \\
\hline Cost ratio & & & \\
\hline $\begin{array}{l}\overline{\text { Hourly }} \\
\text { dRDF } \\
\text { Infeed }\end{array}$ & $\begin{array}{l}\$ / \mathrm{h} \\
\$ / \mathrm{Mg} \text { of dRDF } \\
\$ / \mathrm{Mg} \text { of trommel } \\
\text { infeed }\end{array}$ & $\begin{array}{l}6.13 \\
8.79 \\
4.76\end{array}$ & $\begin{array}{l}6.13 \\
1.13 \\
0.01\end{array}$ \\
\hline
\end{tabular}

\subsection{ECONOMIC CONTRIBUTION OF TROMMEL SCREEN}

\subsubsection{Meeting Product Specifications}

The purpose of the trommel is to improve fuel quality by removing noncombustibles so that fuel specifications can be met. The trommel oversize material is fed to the secondary shredder and then to the pellet mill for production of $\mathrm{dRDF}$ pellets. Pellet specifications are: 
As received

Minimum heating value

Maximum ash content

Maximum moisture content

Minimum bulk density at $20 \%$ moisture

Maximum fines
$-$

$-$

$20 \%$

$561 \mathrm{~kg} / \mathrm{m}^{3}$

$5 \%$

Oven dry basis

$15,120 \mathrm{~kJ} / \mathrm{kg}(6,500 \mathrm{Btu} / \mathrm{lb})$

$15 \%$

(35 $\mathrm{lb} / \mathrm{ft}^{3}$ )

The percent fines and bulk density do not apply to the trommel oversize, as these properties are changed by the pelleting process. Also, moisture content of the pellets would be somewhat lower than the trommel oversize moisture content because the pellets are heated by the frictional resistance of the material being moved through the pellet mill die. Thus, some moisture content would be lost due to increased temperature of the RDF. The heating value and ash content specifications, however, do apply to the trommel oversize as there is no processing between the trommel and the pellet operation that would change either the dry basis heating value or the ash content.

A review of the properties of the $\mathrm{RDF}$ fed to the trommel (Appendix $C$ Tables) shows that the percent dry basis ash is in most cases above $15 \%$. Ash values are usually in the 20 to $30 \%$ range. In only 3 tests of the total 60 tests conducted is the trommel feed dry basis ash content below $15 \%$. Dry basis heating value of the feed material is usually above the $15,120 \mathrm{~kJ} / \mathrm{kg}$ $(6,500 \mathrm{Btu} / \mathrm{lb})$ specification, there being only 5 tests of the 30 heating value tests that fall below this specification. While heating value is not a serious problem for the Baltimore case, the RDF before trommeling cannot meet the ash content fuel specifications. For the RDF to have an economic value, screening or some form of processing to remove ash is necessary.

Figures 8.1 and 8.2 show the oversize dry basis heating value and ash content. In only one case does heating value drop below the fuel specification limit, and this occurred at a feedrate higher than that at which the plant would normally operate. The majority of the oversize heating values fall within an 18,000 to $21,000 \mathrm{~kJ} / \mathrm{kg}$ range, well above the $15,120 \mathrm{~kJ} / \mathrm{kg}$ fuel specification. Plant practice is to operate within a $7 \mathrm{Lu} 13 \mathrm{Mg} / \mathrm{h}$ feedrate. Below $13 \mathrm{Mg} / \mathrm{h}$, the large majority of ash values are below $15 \%$ but in at least 5 tests values were above $15 \%$. While limiting the feedrate will not necessarily guarantee ash below $15 \%$, operating at $13 \mathrm{Mg} / \mathrm{h}$ or below will increase the probability of meeting fuel specifications.

There is an expected trend (Figure 8.3) of increasing dry basis heating value with decreasing ash content. This figure demonstrates that the trommel has an impact on increasing the dRDF energy content through ash removal. 


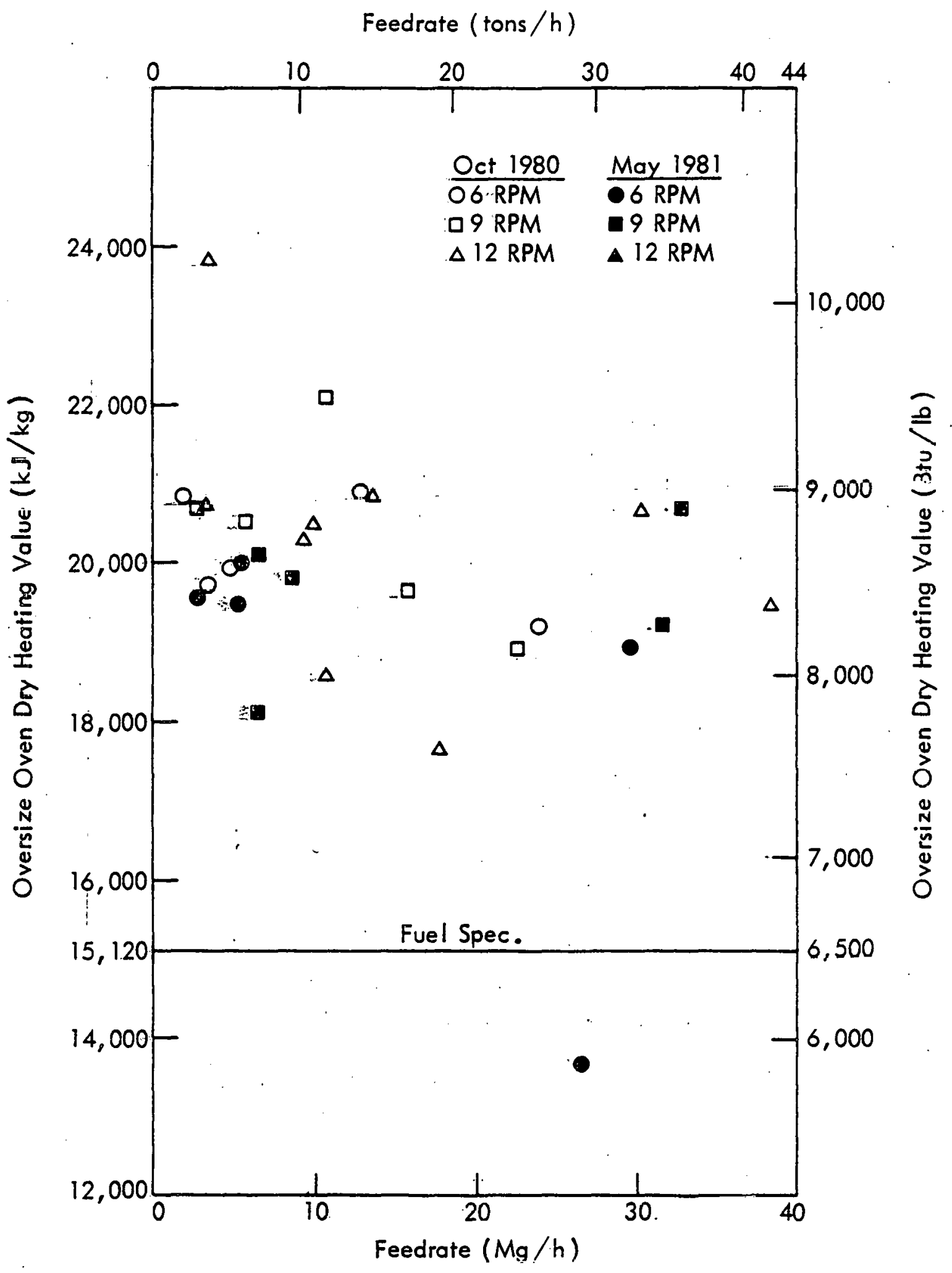

Figure 8.1. Oversize Heating Value Compared to Fuel Specification. 

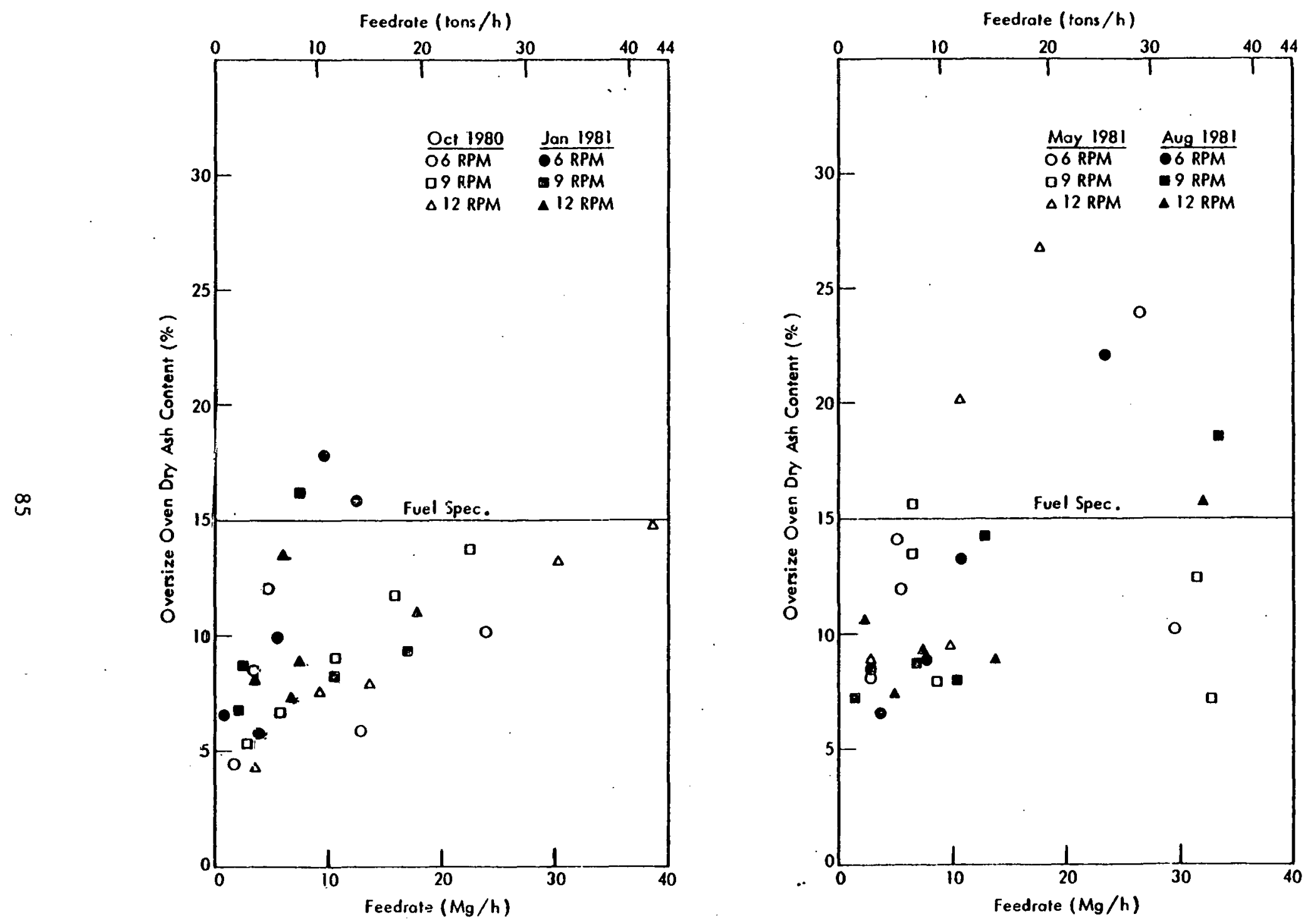

Figure 8.2. Oversize Ash Content Compared to Fuel Specification. 


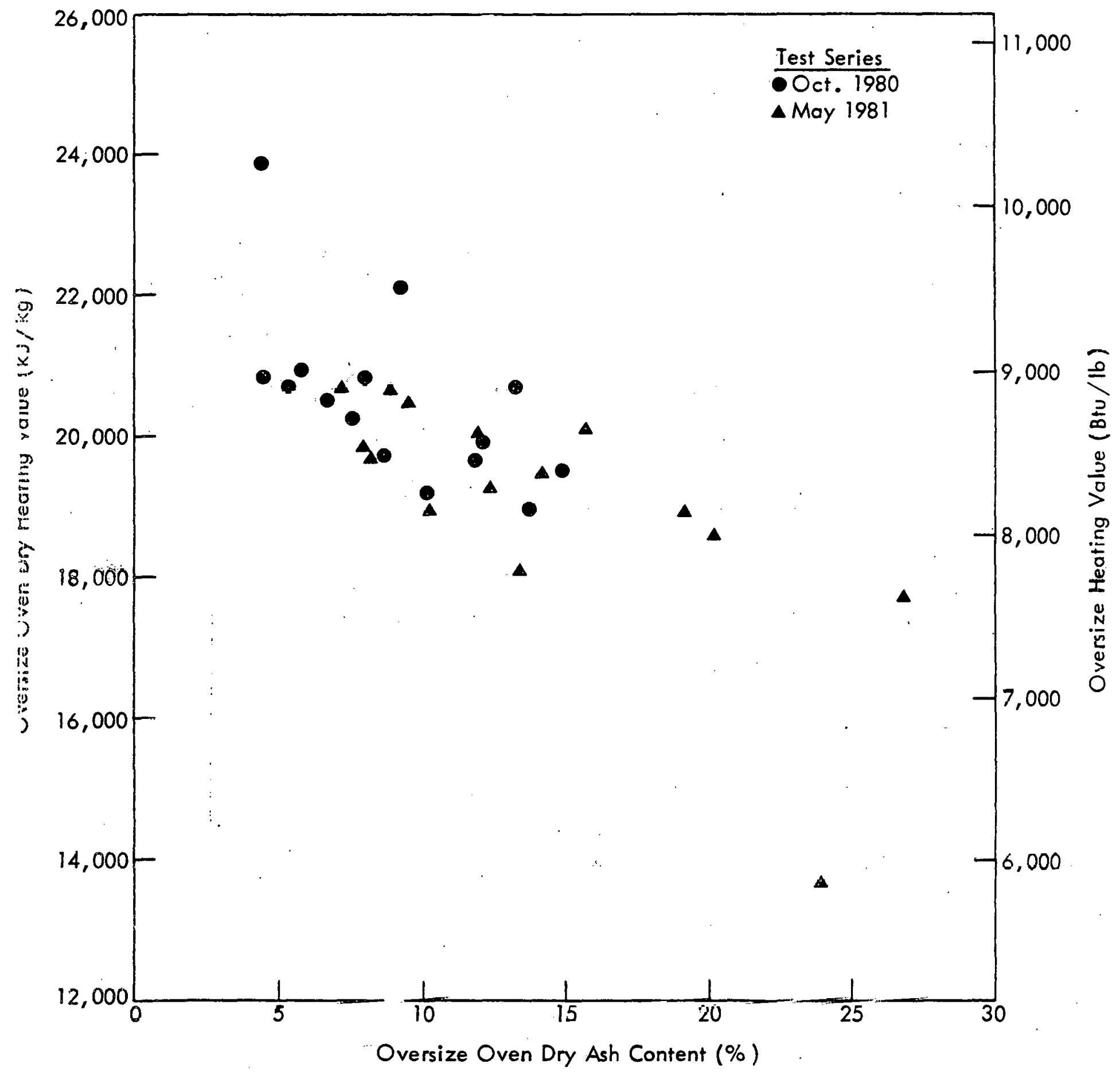

Figure 8.3. Oversize Heating Value Versus Ash Content. 
The net result is that with some exceptions, the tromnel does remove sufficient ash, and heating value is sufficiently high to meet fuel specifications. Without the trommel the $\mathrm{dRDF}$ produced could not be sold; therefore, the trommel makes an economic contribution. This does not rule out considerations such as changing fuel specifications or other processing steps besides trommeling. However, in the specific process flow scheme at Baltimore, the trommel is used to provide the necessary processing step of reducing ash and increasing heating value.

\subsubsection{Economic Measure}

Section 7.0 discussed a variety of parameters used to measure trommel performance such as ash and moisture content removal and organic quality improvement, all of which result in heating value improvement. There were positive results in all these parameters with improvements tending to decrease with an increase in infeed flow rate. The plant operators have chosen through experience an average $10 \mathrm{Mg} / \mathrm{h}(7$ to $13 \mathrm{Mg} / \mathrm{h}$ range) flow rate as one that produces adequate fuel quality. Once it has been established that the trommel is necessary to remove ash to meet fuel specifications, then the only parameter that has a definite economic measure is heating value, as the $\$ / \mathrm{Mg}$ at a specified $\mathrm{kJ} / \mathrm{kg}$ heating value can easily be converted to $\$ / \mathrm{kJ}$ of energy.

For the Baltimore operation shredded MSW is normally landfilled after magnetic ferrous removal. Any $R D F$ that can be sold is a reduction in landfill costs. During the year's evaluation period, only a market for dRDF existed and the market volume was much less than the volume of shredded MSW available for processing. Thus, the fact that a large percentage of the trommel infeed resulted in undersize that was sent to landfill is of no economic consequence in the Baltimore case. What is important is that some ma-

- terial that otherwise would go to landfill is sold. Therefore, an economic model that applies the cost of energy lost in the undersize material is not appropriate for the Baltimore case.

Heating value is improved by the trommel as the heating value of the oversize is always greater than the heating value of the infeed. The most straightforward eronomir. monel. for the Baltimore trommel is to compare the dollar value of the heating value increase to the the total trommel cost. Revenues from the sale of $\mathrm{dRDF}$ and reduction in landfill costs would need to be assigned to the total RDF facility, including the air classifier, secondary shredder, and pellet mill. Therefore, the economic credit due the trommel is only what heating value improvement results due to trommeling.

Heating values were measured during the October 1980 and the May 1981 test series. During all 30 tests, there was an improvement in heating value due to the trommel. The sale price of the dRDF pellets, FOB the Baltimore plant was $\$ 29.76 / \mathrm{Mg}$ ( $\$ 27 /$ ton) and the fuel specification was $15,119 \mathrm{~kJ} / \mathrm{kg}$ $(6,500 \mathrm{Btu} / \mathrm{lb})$ dry basis. The value of the energy is then: 
Therefore, the increase in dry basis $\mathrm{kJ} / \mathrm{kg}$ heating value can be assigned a dollar value. The total cost of the trommel was previously determined to be $\$ 6.13 / \mathrm{h}$, including capital depreciation, operations, and maintenance. The net economic contribution of the trommel is, then, the value of the heating value increase less the trommel cost. Calculational formulas are:

$$
\begin{aligned}
& \$ \mathrm{hvi}=\frac{\mathrm{kJ} / \mathrm{kg} \text { increase } \times \$ 1.968 / 10^{6} \mathrm{~kJ}}{\mathrm{Mg} / 10^{3} \mathrm{~kg}}=\$ / \mathrm{Mg} \mathrm{hvi} \\
& \$ \mathrm{tc}=\frac{\$ 6.13 / \mathrm{h} \text { total cost }}{\mathrm{Mg} / \mathrm{h} \text { infeed } \dot{\mathrm{x}} \text { weight split oversize/infeed }}=\$ / \mathrm{Mg}_{\mathrm{tc}} \\
& \text { Economic contribution of trommel }=\$ / \mathrm{Mg}_{\mathrm{tc}} \\
& \mathrm{hvi}=\text { dry basis heating value increase in } \$ / \mathrm{Mg} \text { of oversize to } \\
& \quad \text { pellet operations } \\
& \mathrm{tc}=\text { trommel total cost in } \$ / \mathrm{Mg} \text { of oversize to pellet operations }
\end{aligned}
$$

This method of determining the trommel economic contribution is based not on the pellet system capability, but on the capability of the trommel and takes into account the variables of percentage of the infeed that becomes overs and all the parameters that improve heating value. These variables change with inteed rate; thus, the trommel economic contribution is calculated over the entire operating range tested. Results are listed in Appendix Table D-4. The effects of feedrate and rotational speed are shown in Figure 8.4 .

The four tests that exceeded the ash content. specification and the one cest that exceeded the heating value specification during the May 1981 test series are not shown in Figure 8.1 . Whilc an econumic cuntribur1on couid be calculated for these test conditions, it would not apply because the product does not meet specifications.

As expected, the characteristics of the oversize material are quite variable because of the wide variability in the MSW delivered to the plant. Therefore, the heating value increase and its resultant dollar value has a great deal of variability. When trommel costs are expressed in $\$ / \mathrm{Mg}$, it is expected that low feedrates would result in low or negative economic contribution by the trommel because, with a low $\mathrm{Mg} / \mathrm{h}$ feedrate, the trommel cost is a high $\$ / M g$ value. Figure 8.4 shows that this can be true at feedrates below $\$ 5 / \mathrm{Mg} / \mathrm{h}$, but there are also exceptions due to large heating value increases in some tests at these low flow rates. The conclusion reached is 


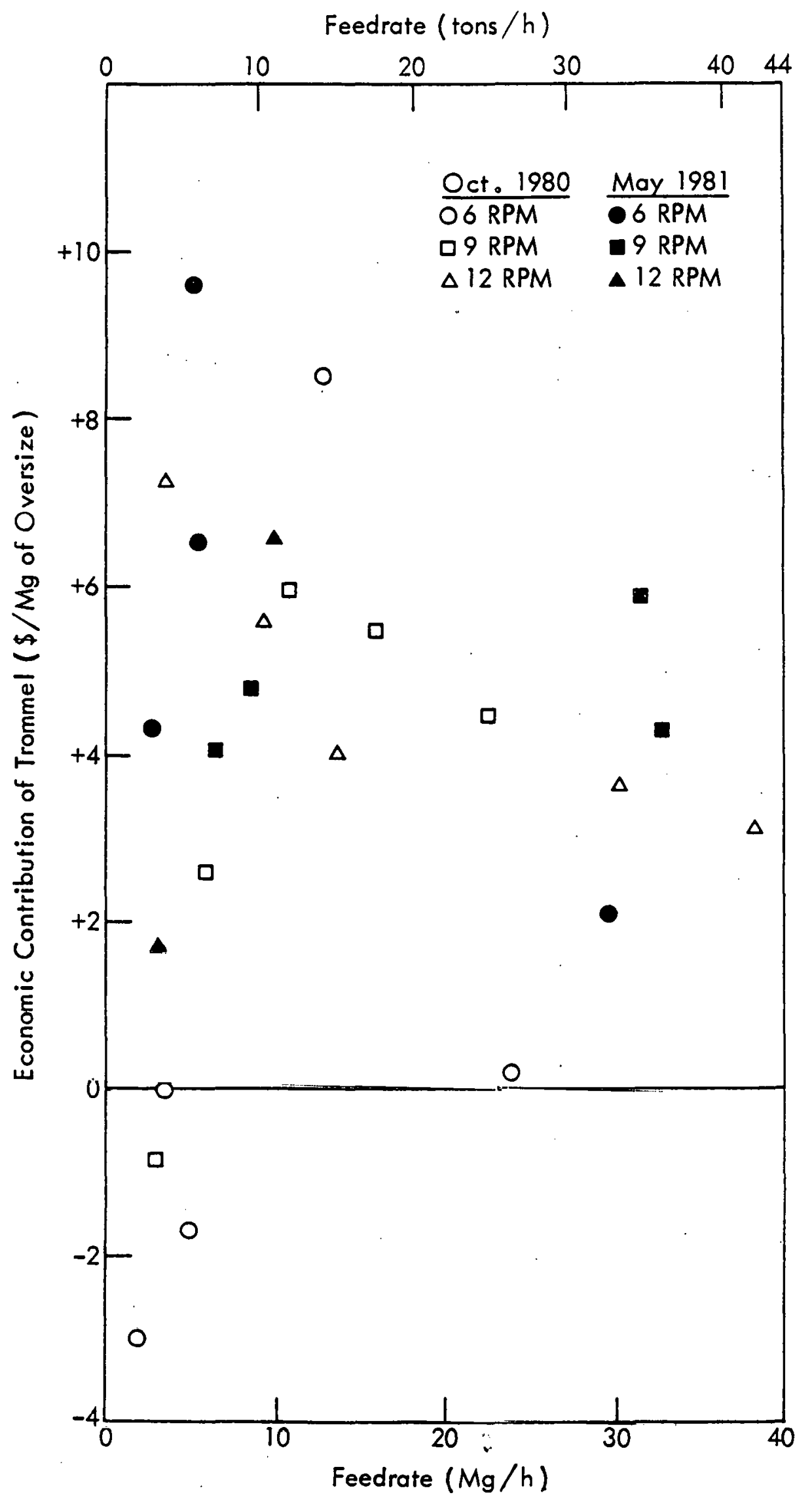

Figure 8.4. Economic Contribution of the Trommel. 


\section{(d) $2 n 0 t)$ torbeg}

that to prevent the possibility of a negative economic contribution occurring, the trommel should be operated above $5 \mathrm{Mg} / \mathrm{h}$, plus a safety factor. This conclusion agrees quite well with the plant operating experience of a $7-\mathrm{Mg} / \mathrm{h}$ minimum flow rate.

Maximum feedrate limits to keep the economic contribution optimized is not well defined from the test data? The economic contribution is $\$ 4 / \mathrm{Mg}$ or above if feedrates exceed $7 \mathrm{Mg} / \mathrm{h}$ until feedrates reach $24 \mathrm{Mg} / \mathrm{h}$. At the higher flow rates $6 \mathrm{rpm}$ results in poorer performance. Plant experience is to keep feedrates below $13 \mathrm{Mg} / \mathrm{h}$ to reduce the probability of exceeding ash content specifications. Figure 8.4 indicates that keeping feedrates within a range of 7 to $13 \mathrm{Mg} / \mathrm{h}$ insures the optimum economic contribution. Within this feedrate economic contribution averages $\$ 6.26 / \mathrm{Mg}$ and ranges from $\$ 4.80$ to $\$ 8.50 / \mathrm{Mg}$.

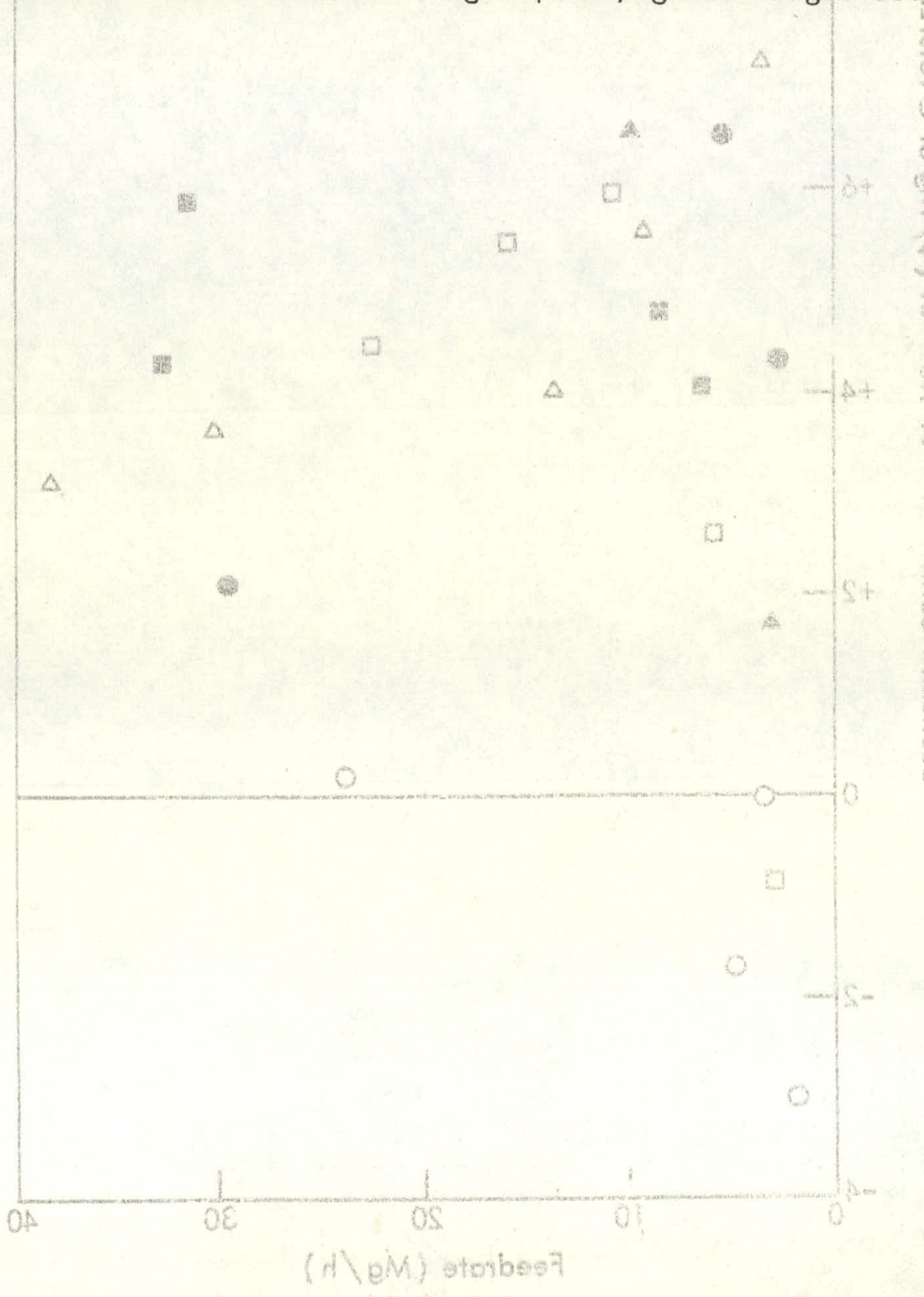




\subsection{REFERENCES}

1. Hopkins, V., Simister, B., and Savage, G.M., Comparative Study of Air Classifiers, EPA-600/2-81-221, NTIS PB82 106121, U.S. Environmental Priotection Agency, Cincinnati, Ohio, September 1981.

2. Savage, G.M., Diaz, L.F., and Trezek, G.J., "Performance Characterization of Air Classifiers in Resource Recovery Processing, "Proceedings of the 1980 National Waste Processing Conference: Resource Recovery Today and Tomorrow, American Society of Mechanical Engineers, New York, May 1980.

3. Glaub, J.C., Jones, D.B., Tleimat, J.U., and Savage, G.M., "Trommel Screen Research and Development for Applications in Resource Recovery," U.S. Department of Energy, San Francisco Operations Office, October 1981.

4. Chemical Engineering, Vol. 89, No. 8, pp. 153-156, McGraw Hill, New York, April 19, 1982 .

5. "Depreciation," Publication 534, Assist Guideline Class 49.5 - Waste Reduction and Resource Recovery Plants, U.S. Department of the Treasury, Internal Revenue Service, Washington, D.C., December 1981. 
$\checkmark$

THIS PAGE

WAS INTENTIONALLY

LEFT BLANK 


\section{GLOSSARY}

Air-Classified Light Fraction (ACLF) - that part of the infeed to an air classifier that is carried away by the airstream.

Air-Dry Moisture Content - the weight lost during drying of the material in ambient air divided by the initial weight of the material. Air drying is typically carried out at 25 to $27^{\circ} \mathrm{C}$.

Air-Dry to Oven-Dry Moisture Content - the weight lost during oven drying of a previously air-dried material divided by the weight of the air-dry material.

Aperture Size - the size of an opening in the screen. For circular apertures, the aperture size is equal to the diameter of the circle. For square apertures, the aperture size is equal to the length of one side of the square.

As-Received - the condition of material at the time of sample collection (i.e., prior to any changes such as drying).

Ash Content - the weight fraction of a sample of material which is not volatilized at a temperature of $700^{\circ} \mathrm{C}$.

Ash Content Removal - the percentage change of the ash content during the course of screening in relation to the ash content of the feed (the ash content of the feed minus the ash content of the oversize fraction, and that quantity divided by the ash content of the feed).

Ash/Energy Content - the mass of ash produced per unit of energy obtained by direct cumbustion (e.g., $\mathrm{kg}$ ash/GJ or $\mathrm{lb}$ ash/MMBtu).

Bed Depth - the depth of material on the screen. For material in kiln action, the bed depth is generally taken at the center of the material.

Bulk Density - the mass per unit volume of an uncompacted porous media. Determined by filling a container of known volume with the material nf interest, while avoiding compaction, and then measuring the weight of the material.

Centrifugal Action - the motion of material in a trommel which is characterized by the material being carried by means of centrifugal force above the horizontal plane that passes through the center of the screen until at some point it detaches from the screen and falls. Distinct from kiln action. 
Characteristic Size - the particle size that corresponds to 63.2 ( 1 - $\frac{1}{e}$ ) cumulative weight percent passing in a particle distribution. Concept of characteristic size is from the Rosin-Rammler distribution.

Component Distribution - the material composition of a sample.

Component/Size Class - a class of material that is composed solely of a certain material component (e.g., paper, glass) and is characterized by a particular range of particle sizes.

Critical Speed - the rotational speed at which the resulting centrifugal force prevents material from falling from the inner surface of the screen. As a consequence, the screen and material rotate as a flywheel.

$\mathrm{dRDF}$ - densified refuse derived fuel.

Dry Basis - value of a measured parameter expressed in terms of the ovendry sample which contains no free moisture.

Energy Recovery - the fraction of calorific energy contained in the material input to a screening operation which is retained in the oversize fraction. The energy recovery is equal to the heating value of the oversize fraction, times the mass fraction of the feed reporting to the oversize fraction, divided by the heating value of the feed material.

Feedrate - mass of material injected into a trommel per unit of time. Also referred to as mass flow rate and mass throughput. During steady-state operation, the feedrate is equal to the undersize flow rate plus the oversize flow rate.

Heating Value - the thermal energy released during combustion of a material per unit of mass of the material. In this report, the reported values are the higher heating values. That is, in the determination of the heating value, no energy is consumed in vaporizing the moisture contained in the material.

Heating Value Improvement - the heating value of the oversize fraction divided by the heating value of the feed. Expressed on a percentage basis.

Holdup Fraction - the fraction of the internal volume of a trommel screen which is occupied by material.

Inclination Angle - the angle between horizontal and the longitudinal axis of the trommel.

Inorganic Other - noncombustible materials other than iron-based metal, aluminum, and glass. In MSW, it includes mainly bones, nonferrous and nonaluminum metals, rocks, and sand.

Kiln Action - the motion of material in a trommel which is characterized by the absence of freefalling particles. In kiln action, particles slide or roll down the slope formed by particles which are being lifted by the screen. 
Leading Edge Time - the residence time of the initial portion of material that enters an empty, rotating screen. Determined by measuring the time: required for the initial material falling into the screen from the feed conveyor to traverse the length of the screen and exit in a uniform front. The few particles that are dispersed forward of the leading edge are ignored.

Lifters - internal elements of a rotating cylinder that serve to carry the material up to a point at which the material falls off the surface. Lifters generally extend the entire length of a trommel and may be constructed in a variety of shapes, including straight bars, notched bars, and cups.

Moisture Content - the weight fraction of a sample of material which is water. (See definitions of air-dry moisture content, air-dry to oven-dry moisture content, oven-dry moisture content, and total moisture content:)

Moisture Content Removal - the percentage change of the moisture content during the course of screening in relation to the moisture content of the feed (the moisture content of the feed minus the moisture content of the oversize fraction, the quantity divided by the moisture content of the feed).

MSW - municipal solid waste.

Nominal Size - the particle size that corresponds to 90.0 cumulative weight percent passing in a particle distribution.

Open Area Fraction - the fraction of the total screen surface area that is comprised of openings in the screen.

Organic Content - the weight fraction of a sample which consists of organic materials.

Organic Other - combustible material which is not paper or plastic. In MSW, it includes mainly food waste, yard waste, and textiles. Synthetic fibers are often included in this category because of the difficulty in distinguishing them from natural fibers.

Organic Quality - equals organic content.

Organic Quality Improvement - the change in the organic quality of the material after traversing the length of the screen. Determined by dividing the organic quality of the oversize fraction by the organic quality of the feed. Expressed on a percentage basis.

Organic Recovery - the weight fraction of the organic material in the infeed which reports to the oversized fraction.

Oven-Dry Moisture Content - the total moisture content of a material dried in an oven at 100 to $105^{\circ} \mathrm{C}$ as referenced to its initial weight before any drying has occurred. 
Oversize Flow Rate - mass of material reporting to the oversize fraction per unit of time.

Oversize Fraction - material which does not pass through the apertures of a screen while traversing the length of the screen. Also referred to as "overs." Distinct from "true oversize" in that some undersize material may not penetrate the screen apertures while the material traverses the length of the screen.

Oversize Split - the weight fraction of the trommel feed material that reports to the oversize fraction.

Particle Size - determined as the size of the smallest aperture that a particle can pass through.

Post-Trommel - a trommel screen which is used to proccss materidl following a comminution stage (e.g., a trommel used to process the air-classified, light fraction.

Pre-Trommel - a trommel screen which is used to process raw MSW which has not been otherwise processed:

Probability of Passage - the probability of a particle passing through an aperture in the screen upon contact with the plane of the screen surface. The plane of the screen surface is defined as the plane tangential to the screen surface and passing through the screen at the point of contact.

Raw MSW - MSW. which has not been pröcessed.

RDF - refuse derived fuel.

Recuvery Factor - the weight fraction of feed material to a unit process which reports to a given output stream from the unit process.

Residence Time - time required for a particle to traverse the entire length of a screen. Particles which pass to the undersized fraction are not included in this definition.

Screening Efficiency - the fraction of undersized material in the Infeed which reports to the undersized fraction during screening.

3ureening Rate - the fraction of undersized material in a screen or specified section of a screen which passes to the undersized fraction during a unit of time or during the time in which the material progresses a unit of axial distance along the screen. Also referred to as "screening rate per unit of distance or per unit. of time."

Size Class - a class of material that is characterized by a particular range of particle sizes. A size class is determined by all of the material passing through a given size screen (the upper limit of the size class). and none of the material passing through a given smaller size screen (the lower limit of the size class). Size class is also referred to as "size fraction." 
Specific Power - the power consumption of a unit or system expressed upon a basis of the feed rate processed. Alternatively formulated in terms of "specific energy."

Split - the trommel feed material which reports to a given output stream. (See recovery factor.)

Total Moisture Content - equals oven-dry moisture content.

Tracer Time - the residence time determined by measuring the time required for a given tracer material to traverse the length of the screen.

Trommel (from the German for "drum") - a cylindrically shaped screen in which the motion of particles is imparted through rotation of the screen and through an inclination of the screen from the horizontal.

True Oversize - material which cannot, because of its size, pass through the apertures of a screen. Also referred to as "actual oversize" or "oversize material." Distinct from "oversize fraction."

True Undersize - material which would pass through the apertures of a screen if ideally oriented in space and if the aperture were not blocked. Also referred to as "actual undersize" and "undersize material."

Undersize Flow Rate - mass of material passing through the screen apertures per unit of time.

Undersize Fraction - material which passes through the apertures of a screen while traversing the screen. Also referred to as "unders." Distinct from "true undersize" in that some true undersize may not report to the undersize fraction during screening.

Undersize Split - the weight fraction of the trommel feed material that reports to the undersize fraction. 
APPENDIX A

DETAILED SAMPLING PROCEDURE

$$
0
$$




\section{Event}

Direct all flow from belt 14 to compactor. Leave all equipment downstream of belt 14 running.

Position secondary recovery (SR) output diverter to direct SR output into SR input. Verify that no material on belt 17 (except trommel unders) reaches belt 18 . Alternatively, have belt No. 17 off and let all air classifier heavies collect in bottom hopper for the duration of the test run.

Verify that all belts and equipment downstream of belt 14 are empty.

Direct flow from belt 14 to belt 15 .

Rake back dribble of material from cyclones until full flow occurs.

Note entrance of leading edge into trommel and begin timing $T_{R 1}$.

Insert tracers into feed and begin timing $\mathrm{T}_{\mathrm{R} 2}$.

Finish timing of $T_{R 1}$ and $T_{R 2}$ upon exit of leadiug edge and first tracer.

Place markers on belts 21 and 18 to indicate begiuming ot sampling period. Begin $T_{s}$ (sampling time). Slup belt 18. Then proceed to repetitiously start and stop it until end of sampling period.

Upon signal, sweep all material from compactor, sweep overs from compactor.

When belt 18 is full (or when it is otherwise decided that enough material has heen rollected), signal eud of sampling period. Simultaneously stop belts 17, 18, and 20 and the trommel (which rauses belt 21 to stop), and stop time $\mathrm{T}_{\mathbf{s}}$.

Stop belts 15 and 19 and redirect all flow from belt 14 to compactor. Also, stop all SR belts.

Duties of Individual Controlling Flow Rate

Receive signal from 2 a indicating that all belts are clear and all personnel are at their stations. 
Signal via TV monitor at air classifier inlet (belt) to control room to open diverter. Continue to signal until diverter is set to permit desired flow rate.

Go to brush at heavies 2 belt (belt 17) and, upon signal from $2 a$, position brush to divert heavies to SR.

Proceed to control room and assist in final shutoff.

Duties of Individuals in RDF Compactor

Two people are required.

One must be within sight of $2 \mathrm{a}$. The other is stationed inside of compactor and sweeps all material from it until the first man relays signal from 2 a indicating that sampling period is beginning. Upon receiving this signal, any material in compactor is jettisoned and subsequent incoming material is saved for analysis.

Station 1: Trommel Infeed

Verify that belts 19 and 20 are running and that the belts are empty. Signal to $2 a$ if all is ready.

Rake back the dribble of material from cyclones on belt 19 until full flow occurs. A distinct leading edge is desirable, but an excessively high "wall" of material is undesirable.

Upon entrance of leading edge into the trommel, signal $2 a$ to begin timing $\mathrm{T}_{\mathrm{R} 1}$. After waiting 30 seconds from when the leading edge enters the trommel, insert tracer cards into the feed. When the cards enter the trommel, signal $2 \mathrm{a}$ to begin timing $\mathrm{T}_{\mathrm{R} 2}$.

Climb down to ground level. Watch 2a for signal that sampling period has started.

When signal is given, go to trommel switchgear and read and record trommel motor voltage and amperage.

Assist in collecting and weighing the sample material.

Procedure Station 2a: (Overs Belt)

S1gnal to man at air classifier feed belt (belt 15) to begin flow.

Watch for signal from Station 1 (trommel inlet) indicating entrance of leading edge. Begin $T_{R 1}$. 
Approximately 30 seconds later watch for signal from Station 1 indicating entrance of tracers. Begin $\mathrm{T}_{\mathrm{R} 2}$.

Approximately 20 seconds later signal to man at heavies 2 belt (belt 17) to activate brush scraper. The timing for this is dictated by the requirement that all heavies which have passed the brush should have time to be transferred to the heavies 3 belt (belt 18) before the commencement of the sampling period.

Watch for appearance of leading edge and tracers. Terminate $T_{R 1}$ and $T_{R 2}$.

Signal beginning of sampling period to $2 \mathrm{~b}$ and man taking power measurements by dropping bag onto RDF belt (belt 21).

Just before bag falls into RDF compactor, signal to man by RDF compactor to sweep out compactor.

Station 2b: Trommel Exit (Unders Belt)

Upon signal from 2a, simultaneously begin $T_{s}$, drop marker onto belt 18. Signal to 3 to stop belt 18 , and continue indicating when to start and stop it until end of run.

When belt 18 is full, and as marker approaches entrance to chute at downstream end of belt, simultaneously end $T_{s}$, indicate final stop to $2 a$ and 3 , and drop marker onto belt 18 .

Prior to initiation of run, person from this station opens and lays out 8 sample bags and 8 bag ties, and prepares duplicate sample labels for each of llie 4 samples. After the run, this person, with assistance from Station 1 person, collects the materials on the unders belt and assists in bulk density weighings, sample quartering, sample collection, and sample labeling. 
APPENDIX B

COMPONENT SIZE DISTRIBUTIONS

B-1 
TABLE B-1. COMPONENT/SIZE DISTRIBUTION (6 rFm feedrate $=1.76 \mathrm{Mg} / \mathrm{h}$ (1.94 tons/h), 0ctober 1980) (\% by weight)

\begin{tabular}{|c|c|c|c|c|c|c|c|c|c|c|c|}
\hline & \multicolumn{2}{|c|}{$\frac{\text { Size class* }}{\mathrm{mm}}$} & \multirow[b]{2}{*}{ Material } & \multirow{2}{*}{$\begin{array}{l}\text { Faper \& } \\
\text { Flastic }\end{array}$} & \multirow{2}{*}{$\begin{array}{l}\text { Organic } \\
\text { other }\end{array}$} & \multirow[b]{2}{*}{ Nonferrous } & \multirow[b]{2}{*}{ Ferrous } & \multirow[b]{2}{*}{ Glass } & \multirow{2}{*}{$\begin{array}{c}\text { Inorganic } \\
\text { other }\end{array}$} & \multirow{2}{*}{$\begin{array}{l}\text { Fines } \\
(-1.30 \mathrm{~mm})\end{array}$} & \multirow[b]{2}{*}{ Total } \\
\hline & $\overline{\mathrm{mm}}$ & in. & & & & & & & & & \\
\hline+76.20 & & +3 & $\begin{array}{l}\text { Feed } \\
\text { Overs } \\
\text { Unders }\end{array}$ & $\begin{array}{r}4.39 \\
12.11 \\
0.00\end{array}$ & $\begin{array}{l}0.00 \\
0.00 \\
0.00\end{array}$ & $\begin{array}{l}0.00 \\
0.00 \\
0.00\end{array}$ & $\begin{array}{l}0.00 \\
0.00 \\
0.00\end{array}$ & $\begin{array}{l}0.00 \\
0.00 \\
0.00\end{array}$ & $\begin{array}{l}0.00 \\
0.00 \\
0.00\end{array}$ & $\begin{array}{l}0.00 \\
0.00 \\
0.00\end{array}$ & $\begin{array}{r}4.39 \\
12.11 \\
0.00\end{array}$ \\
\hline-76.20 & +50.80 & $-3+2$ & $\begin{array}{l}\text { Feed } \\
\text { Overs } \\
\text { Unders }\end{array}$ & $\begin{array}{r}12.79 \\
35.25 \\
0.00\end{array}$ & $\begin{array}{l}0.06 \\
0.15 \\
0.00\end{array}$ & $\begin{array}{l}0.00 \\
0.00 \\
0.00\end{array}$ & $\begin{array}{l}0.00 \\
0.00 \\
0.00\end{array}$ & $\begin{array}{l}0.00 \\
0.00 \\
0.00\end{array}$ & $\begin{array}{l}0.00 \\
0.00 \\
0.00\end{array}$ & $\begin{array}{l}0.00 \\
0.00 \\
0.00\end{array}$ & $\begin{array}{r}12.85 \\
35.40 \\
0.00\end{array}$ \\
\hline-50.80 & +25.40 & $-2+1$ & $\begin{array}{l}\text { Feed } \\
\text { Overs } \\
\text { Unders }\end{array}$ & $\begin{array}{r}11.10 \\
30.60 \\
0.00\end{array}$ & $\begin{array}{l}0.30 \\
0.82 \\
0.00\end{array}$ & $\begin{array}{l}0.00 \\
0.00 \\
0.00\end{array}$ & $\begin{array}{l}0.00 \\
0.00 \\
0.00\end{array}$ & $\begin{array}{l}0.00 \\
0.00 \\
0.00\end{array}$ & $\begin{array}{l}0.00 \\
0.00 \\
0.00\end{array}$ & $\begin{array}{l}0.00 \\
0.00 \\
0.00\end{array}$ & $\begin{array}{r}11.40 \\
31.42 \\
0.00\end{array}$ \\
\hline-25.40 & $+31.75 R$ & $-1+1-1 / 4 R$ & $\begin{array}{l}\text { Feed } \\
\text { Overs } \\
\text { Unders }\end{array}$ & $\begin{array}{l}0.78 \\
2.04 \\
0.06\end{array}$ & $\begin{array}{l}0.03 \\
0.07 \\
0.00\end{array}$ & $\begin{array}{l}0.00 \\
0.00 \\
0.00\end{array}$ & $\begin{array}{l}0.00 \\
0.00 \\
0.00\end{array}$ & $\begin{array}{l}0.00 \\
0.00 \\
0.00\end{array}$ & $\begin{array}{l}1.98 \\
0.00 \\
3.10\end{array}$ & $\begin{array}{l}0.00 \\
0.00 \\
0.00\end{array}$ & $\begin{array}{l}2.79 \\
2.11 \\
3.16\end{array}$ \\
\hline$-31.75 F$ & $R+15.88$ & $\begin{array}{c}-1-1 / 4 R+5 / 8 \\
\end{array}$ & $\begin{array}{l}\text { Feed } \\
\text { Overs } \\
\text { Unders }\end{array}$ & $\begin{array}{r}7.43 \\
11.71 \\
5.00\end{array}$ & $\begin{array}{l}0.30 \\
0.76 \\
0.04\end{array}$ & $\begin{array}{l}0.00 \\
0.00 \\
0.00\end{array}$ & $\begin{array}{l}0.00 \\
0.00 \\
0.00\end{array}$ & $\begin{array}{l}0.00 \\
0.00 \\
0.00\end{array}$ & $\begin{array}{l}0.00 \\
0.00 \\
0.00\end{array}$ & $\begin{array}{l}0.00 \\
0.00 \\
0.00\end{array}$ & $\begin{array}{r}7.73 \\
12.47 \\
5.04\end{array}$ \\
\hline-15.88 & +1.30 & $-5 / 8+0.051$ & $\begin{array}{l}\text { Feed } \\
\text { Overs } \\
\text { Unders }\end{array}$ & $\begin{array}{r}30.69 \\
4.92 \\
45.37\end{array}$ & $\begin{array}{l}2.33 \\
0.16 \\
3.57\end{array}$ & $\begin{array}{l}0.15 \\
0.00 \\
0.24\end{array}$ & $\begin{array}{l}0.00 \\
0.00 \\
0.00\end{array}$ & $\begin{array}{l}4.70 \\
0.00 \\
7.37\end{array}$ & $\begin{array}{l}1.77 \\
0.00 \\
2.78\end{array}$ & $\begin{array}{l}0.00 \\
0.00 \\
0.00\end{array}$ & $\begin{array}{r}39.64 \\
5.08 \\
59.33\end{array}$ \\
\hline-1.30 & & -0.051 & $\begin{array}{l}\text { Feed } \\
\text { Overs } \\
\text { Unders }\end{array}$ & $\begin{array}{l}0.00 \\
0.00 \\
0.00\end{array}$ & $\begin{array}{l}0.00 \\
0.00 \\
0.00\end{array}$ & $\begin{array}{l}0.00 \\
0.00 \\
0.00\end{array}$ & $\begin{array}{l}0.00 \\
0.00 \\
0.00\end{array}$ & $\begin{array}{l}0.00 \\
0.00 \\
0.00\end{array}$ & $\begin{array}{l}0.00 \\
0.00 \\
0.00\end{array}$ & $\begin{array}{r}21.20 \\
1.41 \\
32.47\end{array}$ & $\begin{array}{r}21.20 \\
1.41 \\
32.47\end{array}$ \\
\hline Total & & - & $\begin{array}{l}\text { Feed } \\
\text { Overs } \\
\text { Unders }\end{array}$ & $\begin{array}{l}67.18 \\
96.63 \\
50.43\end{array}$ & $\begin{array}{l}3.02 \\
1.96 \\
3.61\end{array}$ & $\begin{array}{l}0.15 \\
0.00 \\
0.24\end{array}$ & $\begin{array}{l}0.00 \\
0.00 \\
0.00\end{array}$ & $\begin{array}{l}4.70 \\
0.00 \\
7.37\end{array}$ & $\begin{array}{l}3.75 \\
0: 00 \\
5.88\end{array}$ & $\begin{array}{r}21.20 \\
1.41 \\
32.47\end{array}$ & $\begin{array}{l}100.00 \\
100.00 \\
100.00\end{array}$ \\
\hline
\end{tabular}

$\because \mathrm{R}$ designates round sieve opening. 
TABLE B-2. COMPONENT/SIZE DISTRIBUTION $(6 \mathrm{rpm}$, feedrate $=3.13 \mathrm{Mg} / \mathrm{h}(3.44 \mathrm{tons} / \mathrm{h})$, 0ctober 1980) (\% by weight)

\begin{tabular}{|c|c|c|c|c|c|c|c|c|c|c|c|}
\hline & \multicolumn{2}{|c|}{ Size class* } & \multirow{2}{*}{ Material } & \multirow{2}{*}{$\begin{array}{l}\text { Paper \& } \\
\text { plastic }\end{array}$} & \multirow{2}{*}{$\begin{array}{l}\text { Organic } \\
\text { other }\end{array}$} & \multirow[b]{2}{*}{ Nonferrous } & \multirow[b]{2}{*}{ Ferrous } & \multirow{2}{*}{ Glass } & \multirow{2}{*}{$\begin{array}{c}\text { Inorganic } \\
\text { other }\end{array}$} & \multirow{2}{*}{$\begin{array}{l}\text { Fines } \\
(-1.30 \mathrm{~mm})\end{array}$} & \multirow[b]{2}{*}{ Total } \\
\hline & $\mathrm{nm}$ & in. & & & & & & & & & \\
\hline+76.20 & & +3 & $\begin{array}{l}\text { Feed } \\
\text { Overs } \\
\text { Unders }\end{array}$ & $\begin{array}{r}6.69 \\
13.53 \\
0.00\end{array}$ & $\begin{array}{l}0.00 \\
0.00 \\
0.00\end{array}$ & $\begin{array}{l}0.00 \\
0.00 \\
0.00\end{array}$ & $\begin{array}{l}0.00 \\
0.00 \\
0.00\end{array}$ & $\begin{array}{l}0.00 \\
0.00 \\
0.00\end{array}$ & $\begin{array}{l}0.00 \\
0.00 \\
0.00\end{array}$ & $\begin{array}{l}0.00 \\
0.00 \\
0.00\end{array}$ & $\begin{array}{r}6.69 \\
13.53 \\
0.00\end{array}$ \\
\hline-76.20 & +50.80 & $-3+2$ & $\begin{array}{l}\text { Feed } \\
\text { Overs } \\
\text { Unders }\end{array}$ & $\begin{array}{r}12.51 \\
25.31 \\
0.00\end{array}$ & $\begin{array}{l}0.00 \\
0.00 \\
0.00\end{array}$ & $\begin{array}{l}0.00 \\
0.00 \\
0.00\end{array}$ & $\begin{array}{l}0.00 \\
0.00 \\
0.00\end{array}$ & $\begin{array}{l}0.00 \\
0.00 \\
0.00\end{array}$ & $\begin{array}{l}0.00 \\
0.00 \\
0.00\end{array}$ & $\begin{array}{l}0.00 \\
0.00 \\
0.00\end{array}$ & $\begin{array}{r}12.51 \\
25.31 \\
0.00\end{array}$ \\
\hline-50.80 & +25.40 & $-2+1$ & $\begin{array}{l}\text { Feed } \\
\text { Overs } \\
\text { Unders }\end{array}$ & $\begin{array}{r}17.42 \\
35.24 \\
0.00\end{array}$ & $\begin{array}{l}0.57 \\
1.14 \\
0.00\end{array}$ & $\begin{array}{l}0.90 \\
1.81 \\
0.00\end{array}$ & $\begin{array}{l}0.00 \\
0.00 \\
0.00\end{array}$ & $\begin{array}{l}0.00 \\
0.00 \\
0.00\end{array}$ & $\begin{array}{l}0.00 \\
0.00 \\
0.00\end{array}$ & $\begin{array}{l}0.00 \\
0.00 \\
0.00\end{array}$ & $\begin{array}{r}18.89 \\
38.19 \\
0.00\end{array}$ \\
\hline-25.40 & $+31.75 R$ & $-1+1-1 / 4 R$ & $\begin{array}{l}\text { Feed } \\
\text { Overs } \\
\text { Unders }\end{array}$ & $\begin{array}{l}0.74 \\
1.44 \\
0.06\end{array}$ & $\begin{array}{l}0.09 \\
0.19 \\
0.00\end{array}$ & $\begin{array}{l}0.00 \\
0.00 \\
0.00\end{array}$ & $\begin{array}{l}0.00 \\
0.00 \\
0.00\end{array}$ & $\begin{array}{l}0.00 \\
0.00 \\
0.00\end{array}$ & $\begin{array}{l}0.00 \\
0.00 \\
0.00\end{array}$ & $\begin{array}{l}0.00 \\
0.00 \\
0.00\end{array}$ & $\begin{array}{l}0.83 \\
1.63 \\
0.06\end{array}$ \\
\hline$-31.75 R$ & $R+15.88$ & $-1-1 / 4 R+5 / 8$ & $\begin{array}{l}\text { Feed } \\
\text { Overs } \\
\text { Unders }\end{array}$ & $\begin{array}{r}7.39 \\
10.90 \\
3.95\end{array}$ & $\begin{array}{l}0.49 \\
0.45 \\
0.53\end{array}$ & $\begin{array}{l}0.00 \\
0.00 \\
0.00\end{array}$ & $\begin{array}{l}0.00 \\
0.00 \\
0.00\end{array}$ & $\begin{array}{l}0.00 \\
0.00 \\
0.00\end{array}$ & $\begin{array}{l}0.00 \\
0.00 \\
0.00\end{array}$ & $\begin{array}{l}0.00 \\
0.00 \\
0.00\end{array}$ & $\begin{array}{r}7.88 \\
11.35 \\
4.48\end{array}$ \\
\hline-15.88 & +1.30 & $-5 / 8+0.051$ & $\begin{array}{l}\text { Feed } \\
\text { Overs } \\
\text { Unders }\end{array}$ & $\begin{array}{r}27.91 \\
7.08 \\
48.27\end{array}$ & $\begin{array}{l}3.94 \\
1.17 \\
6.66\end{array}$ & $\begin{array}{l}0.32 \\
0.23 \\
0.42\end{array}$ & $\begin{array}{l}0.00 \\
0.00 \\
0.00\end{array}$ & $\begin{array}{l}0.68 \\
0.00 \\
1.34\end{array}$ & $\begin{array}{l}0.20 \\
0.00 \\
0.41\end{array}$ & $\begin{array}{l}0.00 \\
0.00 \\
0.00\end{array}$ & $\begin{array}{r}33.05 \\
8.48 \\
57.10\end{array}$ \\
\hline-1.30 & & -0.051 & $\begin{array}{l}\text { Feed } \\
\text { Overs } \\
\text { Unders }\end{array}$ & $\begin{array}{l}0.00 \\
0.00 \\
0.00\end{array}$ & $\begin{array}{l}0.00 \\
0.00 \\
0.00\end{array}$ & $\begin{array}{l}0.00 \\
0.00 \\
0.00\end{array}$ & $\begin{array}{l}0.00 \\
0.00 \\
0.00\end{array}$ & $\begin{array}{l}0.00 \\
0.00 \\
0.00\end{array}$ & $\begin{array}{l}0.00 \\
0.00 \\
0.00\end{array}$ & $\begin{array}{r}20.15 \\
1.51 \\
38.36\end{array}$ & $\begin{array}{r}20.15 \\
1.51 \\
38.36\end{array}$ \\
\hline Total & & - & $\begin{array}{l}\text { Feed } \\
\text { Overs } \\
\text { Unders }\end{array}$ & $\begin{array}{l}72.66 \\
93.50 \\
52.28\end{array}$ & $\begin{array}{l}5.09 \\
2.95 \\
7.19\end{array}$ & $\begin{array}{l}1.22 \\
2.04 \\
0.42\end{array}$ & $\begin{array}{l}0.00 \\
0.00 \\
0.00\end{array}$ & $\begin{array}{l}0.68 \\
0.00 \\
1.34\end{array}$ & $\begin{array}{l}0.20 \\
0.00 \\
0.41\end{array}$ & $\begin{array}{r}20.15 \\
1.51 \\
38.36\end{array}$ & $\begin{array}{l}100.00 \\
100.00 \\
100.00\end{array}$ \\
\hline
\end{tabular}

* R designates round sieve opening. 
TABLE B-3. COHPONENT/SIZE JISTRIBUTION (6 rpais feedrate $=4.74 \mathrm{Mg} / \mathrm{h}(5.21$ tons $/ \mathrm{h}$ ), October 1980) (\% by weight)

\begin{tabular}{|c|c|c|c|c|c|c|c|c|c|c|c|}
\hline & \multicolumn{2}{|c|}{ Size class* } & \multirow[b]{2}{*}{ Material } & \multirow{2}{*}{$\begin{array}{l}\text { Peper \& } \\
\text { plastic }\end{array}$} & \multirow{2}{*}{$\begin{array}{l}\text { Ozganic } \\
\text { other }\end{array}$} & \multirow[b]{2}{*}{ Nonferrous } & \multirow[b]{2}{*}{ Ferrcus } & \multirow[b]{2}{*}{ Glass } & \multirow{2}{*}{$\begin{array}{c}\text { Inorganic } \\
\text { other }\end{array}$} & \multirow{2}{*}{$\begin{array}{l}\text { Fines } \\
(-1.30 \mathrm{~mm})\end{array}$} & \multirow[b]{2}{*}{ Total } \\
\hline & $\min$ & in. & & & & & & & & & \\
\hline$+76: 20$ & & +3 & $\begin{array}{l}\text { Feed } \\
\text { Overs } \\
\text { Unders }\end{array}$ & $\begin{array}{r}5.89 \\
20.07 \\
0.00\end{array}$ & $\begin{array}{l}0.08 \\
0.28 \\
0.00\end{array}$ & $\begin{array}{l}0.00 \\
0.00 \\
0.00\end{array}$ & $\begin{array}{l}0.00 \\
0.00 \\
0.00\end{array}$ & $\begin{array}{l}0.00 \\
0.00 \\
0.00\end{array}$ & $\begin{array}{l}0.00 \\
0.00 \\
0.00\end{array}$ & $\begin{array}{l}0.00 \\
0.00 \\
0.00\end{array}$ & $\begin{array}{r}5.97 \\
20.35 \\
0.00\end{array}$ \\
\hline-76.20 & +50.80 & $-3+2$ & $\begin{array}{l}\text { Feed } \\
\text { Overs } \\
\text { Unders }\end{array}$ & $\begin{array}{r}5.77 \\
19.66 \\
0.00\end{array}$ & $\begin{array}{l}0.08 \\
0.29 \\
0.00\end{array}$ & $\begin{array}{l}0.00 \\
0.00 \\
0.00\end{array}$ & $\begin{array}{l}0.00 \\
0.03 \\
0.03\end{array}$ & $\begin{array}{l}0.00 \\
0.00 \\
0.00\end{array}$ & $\begin{array}{l}0.00 \\
0.00 \\
0.00\end{array}$ & $\begin{array}{l}0.00 \\
0.00 \\
0.00\end{array}$ & $\begin{array}{r}5.85 \\
19.95 \\
0.00\end{array}$ \\
\hline-50.80 & +25.40 & $-2+1$ & $\begin{array}{l}\text { Feed } \\
\text { Overs } \\
\text { Unders }\end{array}$ & $\begin{array}{r}3.26 \\
31.52 \\
0.00\end{array}$ & $\begin{array}{l}0.54 \\
1.83 \\
0.00\end{array}$ & $\begin{array}{l}0.00 \\
0.00 \\
0.00\end{array}$ & $\begin{array}{l}0.010 \\
0.00 \\
0.00\end{array}$ & $\begin{array}{l}0.00 \\
0.00 \\
0.00\end{array}$ & $\begin{array}{l}0.00 \\
0.00 \\
0.00\end{array}$ & $\begin{array}{l}0.00 \\
0.00 \\
0.00\end{array}$ & $\begin{array}{r}9.80 \\
33.35 \\
0.00\end{array}$ \\
\hline-25.40 & $+31.75 R$ & $-1+1-1 / 4 R$ & $\begin{array}{l}\text { Feed } \\
\text { Overs } \\
\text { Unders }\end{array}$ & $\begin{array}{l}0.69 \\
2.06 \\
0.12\end{array}$ & $\begin{array}{l}0.02 \\
0.05 \\
0.00\end{array}$ & $\begin{array}{l}0.00 \\
0.00 \\
0.00\end{array}$ & $\begin{array}{l}0.00 \\
0.00 \\
0.00\end{array}$ & $\begin{array}{l}0.00 \\
0.00 \\
0.00\end{array}$ & $\begin{array}{l}0.00 \\
0.00 \\
0.00\end{array}$ & $\begin{array}{l}0.00 \\
0.00 \\
0.00\end{array}$ & $\begin{array}{l}0.71 \\
2.11 \\
0.12\end{array}$ \\
\hline $\begin{array}{r}-31.75 R \\
\ldots\end{array}$ & $\begin{array}{c}\mathbf{R}+\mathbf{1 5 . 8 8} \\
-\quad-\quad\end{array}$ & $\begin{array}{c}-1-1 / 4 R+5 / 8 \\
-\end{array}$ & $\begin{array}{l}\text { Feed } \\
\text { Overs } \\
\text { Unders }\end{array}$ & $\begin{array}{r}7.86 \\
13.46 \\
5.53\end{array}$ & $\begin{array}{l}2.66 \\
1.12 \\
3.30\end{array}$ & $\begin{array}{l}0.00 \\
0.00 \\
0.00\end{array}$ & $\begin{array}{l}0.00 \\
0.00 \\
0.0 C\end{array}$ & $\begin{array}{l}0.00 \\
0.00 \\
0.00\end{array}$ & $\begin{array}{l}0.00 \\
0.00 \\
0.00\end{array}$ & $\begin{array}{l}0.00 \\
0.00 \\
0.00\end{array}$ & $\begin{array}{r}10.52 \\
14.58 \\
8.83\end{array}$ \\
\hline-15.88 & +1.30 & $-5 / 8+0.051$ & $\begin{array}{l}\text { Feed } \\
\text { Overs } \\
\text { Unders }\end{array}$ & $\begin{array}{r}43.17 \\
.7 .12 \\
58.17\end{array}$ & $\begin{array}{l}5.36 \\
=.43 \\
6.99\end{array}$ & $\begin{array}{l}0.55 \\
0.00 \\
0.77\end{array}$ & $\begin{array}{l}0.26 \\
0.00 \\
0.37\end{array}$ & $\begin{array}{l}5.79 \\
0.03 \\
8.19\end{array}$ & $\begin{array}{l}0.84 \\
0.03 \\
1.17\end{array}$ & $\begin{array}{l}0.00 \\
0.00 \\
0.00\end{array}$ & $\begin{array}{r}55.97 \\
8.61 \\
75.66\end{array}$ \\
\hline-1.30 & & -0.051 & $\begin{array}{l}\text { Feed } \\
\text { Overs } \\
\text { Unders }\end{array}$ & $\begin{array}{l}0.00 \\
0.00 \\
0.00\end{array}$ & $\begin{array}{l}0.00 \\
0.00 \\
C .00\end{array}$ & $\begin{array}{l}0.00 \\
0.00 \\
0.00\end{array}$ & $\begin{array}{l}0.00 \\
0.00 \\
0.00\end{array}$ & $\begin{array}{l}0.00 \\
0.00 \\
0.00\end{array}$ & $\begin{array}{l}0.00 \\
0.00 \\
0.00\end{array}$ & $\begin{array}{r}11.18 \\
1.05 \\
15.39\end{array}$ & $\begin{array}{l}11.18 \\
1.05 \\
15.39\end{array}$ \\
\hline Total & . & - & $\begin{array}{l}\text { Feed } \\
\text { Overs } \\
\text { Unders }\end{array}$ & $\begin{array}{l}72.64 \\
93.89 \\
63.82\end{array}$ & $\begin{array}{r}8.74 \\
5.00 \\
10.29\end{array}$ & $\begin{array}{l}0.55 \\
0.00 \\
0.77\end{array}$ & $\begin{array}{l}0.26 \\
0.00 \\
0.37\end{array}$ & $\begin{array}{l}5.79 \\
0.03 \\
8.19\end{array}$ & $\begin{array}{l}0.84 \\
0.03 \\
1.17\end{array}$ & $\begin{array}{r}11.18 \\
1.05 \\
15.39\end{array}$ & $\begin{array}{l}100.00 \\
100.00 \\
100.00\end{array}$ \\
\hline
\end{tabular}

$*$ R designates round sieve opening. 
TABLE B-4. COMPONENT/SIZE DISTRIBUTION $(6 \mathrm{rpm}$, feedrate $=12.84 \mathrm{Mg} / \mathrm{h}(14.12 \mathrm{tons} / \mathrm{h})$, Oclober 1980)

(\% by weight)

\begin{tabular}{|c|c|c|c|c|c|c|c|c|c|c|c|}
\hline & \multicolumn{2}{|c|}{$\frac{\text { Size class } \stackrel{\star}{n}}{\text { in }}$} & \multirow[b]{2}{*}{ Material } & \multirow{2}{*}{$\begin{array}{l}\text { Paper \& } \\
\text { plastic }\end{array}$} & \multirow{2}{*}{$\begin{array}{l}\text { Organic } \\
\text { other }\end{array}$} & \multirow[b]{2}{*}{ Nonferrous } & \multirow[b]{2}{*}{ Ferrous } & \multirow[b]{2}{*}{ Glass } & \multirow{2}{*}{$\begin{array}{l}\text { Inorganic } \\
\text { other }\end{array}$} & \multirow{2}{*}{$\begin{array}{l}\text { Fines } \\
(-1.30 \mathrm{~mm})\end{array}$} & \multirow[b]{2}{*}{ Total } \\
\hline & $\mathbf{m m}$ & in. & & & & & & & & & \\
\hline \multirow[t]{3}{*}{+76.20} & & +3 & Feed & 4.38 & 0.00 & 0.00 & 0.00 & 0.00 & 0.00 & 0.00 & 4.38 \\
\hline & & & Overs & 9.23 & 0.00 & 0.00 & 0.00 & 0.00 & 0.00 & 0.00 & 9.23 \\
\hline & & & Unders & 0.00 & 0.00 & 0.00 & 0.00 & 0.00 & 0.00 & 0.00 & 0.00 \\
\hline \multirow[t]{3}{*}{-76.20} & +50.80 & $-3+2$ & Feed & 8.11 & 0.00 & 0.00 & 0.00 & 0.00 & 0.00 & 0.00 & 8.11 \\
\hline & & & Overs & 17.09 & 0.00 & 0.00 & 0.00 & 0.00 & 0.00 & 0.00 & 17.09 \\
\hline & & & Unders & 0.00 & 0.00 & 0.00 & 0.00 & 0.00 & 0.00 & 0.00 & 0.00 \\
\hline \multirow[t]{3}{*}{-50.80} & +25.40 & $-2+1$ & Feed & 9.51 & 0.92 & 0.00 & 0.00 & 0.00 & 0.00 & 0.00 & 10.43 \\
\hline & & & Overs & 20.06 & 1.95 & 0.00 & 0.00 & 0.00 & 0.00 & 0.00 & 22.01 \\
\hline & & & Unders & 0.00 & 0.00 & 0.00 & 0.00 & 0.00 & 0.00 & 0.00 & 0.00 \\
\hline \multirow{3}{*}{-25.40} & $+31.75 R$ & $-1+1-1 / 4 R$ & Feed & 2.93 & 0.00 & 0.00 & 0.00 & 0.00 & 0.00 & 0.00 & 2.93 \\
\hline & & & Overs & 3.02 & 0.00 & 0.00 & 0.00 & 0.00 & 0.00 & 0.00 & 3.02 \\
\hline & & & Unders & 2.86 & 0.00 & 0.00 & 0.00 & 0.00 & 0.00 & 0.00 & 2.86 \\
\hline \multirow[t]{3}{*}{$-31.75 R$} & $R+15.88$ & $-1-1 / 4 R+5 / 8$ & Feed & 9.15 & 1.34 & 0.00 & 0.00 & 0.00 & 0.89 & 0.00 & 11.38 \\
\hline & & & Overs & 14.62 & 0.51 & 0.00 & 0.00 & 0.00 & 0.00 & 0.00 & 15.13 \\
\hline & & & Unders & 4.21 & 2.09 & 0.00 & 0.00 & 0.00 & 1.70 & 0.00 & 8.00 \\
\hline \multirow[t]{3}{*}{-15.88} & +1.30 & $-5 / 8+0.051$ & Feed & 30.94 & 1.23 & 0.20 & 0.00 & 12.23 & 3.26 & 0.00 & 47.86 \\
\hline & & & Overs & 24.73 & 1.92 & 0.00 & 0.00 & 0.32 & 0.14 & 0.00 & 27.11 \\
\hline & & & Unders & 36.54 & 0.60 & 0.38 & 0.00 & 22.98 & 6.07 & 0.00 & 66.57 \\
\hline \multirow[t]{3}{*}{-1.30} & & -0.051 & Feed & 0.00 & 0.00 & 0.00 & 0.00 & 0.00 & 0.00 & 14.91 & 14.91 \\
\hline & & & Overs & 0.00 & 0.00 & 0.00 & 0.00 & 0.00 & 0.00 & 6.41 & 6.41 \\
\hline & & & Unders & 0.00 & 0.00 & 0.00 & 0.00 & 0.00 & 0.00 & 22.57 & 22.57 \\
\hline \multirow[t]{3}{*}{ Total } & & - & Feed & 65.02 & 3.49 & 0.20 & 0.00 & 12.23 & 4.15 & 14.91 & 100.00 \\
\hline & & & Overs & 88.75 & 4.38 & 0.00 & 0.00 & 0.32 & 0.14 & 6.41 & 100.00 \\
\hline & & & Unders & 43.61 & 2.69 & 0.38 & 0.00 & 22.98 & 7.77 & .22 .57 & 100.00 \\
\hline
\end{tabular}

* R designates round sieve opening. 
TABLE B-5. COMPONENT/SIZE DISTRIBUTICN (6 $\mathrm{rpar}_{\text {; }}$ feedrate $=23.91 \mathrm{gg} / \mathrm{h}(26.30 \mathrm{tons} / \mathrm{h})$, October 1980) (\% by weight)

\begin{tabular}{|c|c|c|c|c|c|c|c|c|c|c|c|}
\hline & \multicolumn{2}{|c|}{ Size class* } & \multirow{2}{*}{ Material } & \multirow{2}{*}{$\begin{array}{l}\text { Paper \& } \\
\text { plastic. }\end{array}$} & \multirow{2}{*}{$\begin{array}{c}\text { Organic } \\
\text { other }\end{array}$} & \multirow[b]{2}{*}{ Nonferrous } & \multirow[b]{2}{*}{ Ferroụs } & \multirow[b]{2}{*}{ Glass } & \multirow{2}{*}{$\begin{array}{c}\text { Inorganic } \\
\text { other }\end{array}$} & \multirow{2}{*}{$\begin{array}{l}\text { Fines } \\
(-1.30 \mathrm{~mm})\end{array}$} & \multirow[b]{2}{*}{ Total } \\
\hline & $\mathrm{mm}$ & in. & & & & & & & & & \\
\hline+76.20 & & +3 & $\begin{array}{l}\text { Feed } \\
\text { Overs } \\
\text { Unders }\end{array}$ & $\begin{array}{l}6.79 \\
8.93 \\
0.00\end{array}$ & $\begin{array}{l}0.74 \\
0.97 \\
0.00\end{array}$ & $\begin{array}{l}0.00 \\
0.00 \\
0.00\end{array}$ & $\begin{array}{l}0.00 \\
0.00 \\
0.00\end{array}$ & $\begin{array}{l}0.00 \\
0.00 \\
0.00\end{array}$ & $\begin{array}{l}0.00 \\
0.00 \\
0.00\end{array}$ & $\begin{array}{l}0.00 \\
0.00 \\
0.00\end{array}$ & $\begin{array}{l}7.53 \\
9.90 \\
0.00\end{array}$ \\
\hline-76.20 & +50.80 & $-3+2$ & $\begin{array}{l}\text { Feed } \\
\text { Overs } \\
\text { Unders }\end{array}$ & $\begin{array}{l}5.04 \\
6.62 \\
0.00\end{array}$ & $\begin{array}{l}0.00 \\
0.00 \\
0.00\end{array}$ & $\begin{array}{l}0.00 \\
0.00 \\
0.00\end{array}$ & $\begin{array}{l}0.00 \\
0.00 \\
0.01\end{array}$ & $\begin{array}{l}0.00 \\
0.00 \\
0.00\end{array}$ & $\begin{array}{l}0.00 \\
0.00 \\
0.00\end{array}$ & $\begin{array}{l}0.00 \\
0.00 \\
0.00\end{array}$ & $\begin{array}{l}5.04 \\
6.62 \\
0.00\end{array}$ \\
\hline-50.80 & +25.40 & $-2+1$ & $\begin{array}{l}\text { Feed } \\
\text { Overs } \\
\text { Unders }\end{array}$ & $\begin{array}{r}11.44 \\
15.04 \\
0.00\end{array}$ & $\begin{array}{l}0.02 \\
0.03 \\
0.00\end{array}$ & $\begin{array}{l}0.00 \\
0.00 \\
0.00\end{array}$ & $\begin{array}{l}0.00 \\
0.00 \\
0.00\end{array}$ & $\begin{array}{l}0.00 \\
0.00 \\
0.00\end{array}$ & $\begin{array}{l}0.00 \\
0.00 \\
0.00\end{array}$ & $\begin{array}{l}0.00 \\
0.00 \\
0.00\end{array}$ & $\begin{array}{r}11.46 \\
15.07 \\
0.00\end{array}$ \\
\hline-25.40 & $+31.75 R$ & $-1+1-1 / 4 R$ & $\begin{array}{l}\text { Feed } \\
\text { Overs } \\
\text { Unders }\end{array}$ & $\begin{array}{l}1.88 \\
2.47 \\
0.00\end{array}$ & $\begin{array}{l}0.00 \\
0.00 \\
0.00\end{array}$ & $\begin{array}{l}0.00 \\
0.00 \\
0.00\end{array}$ & $\begin{array}{l}0.00 \\
0.00 \\
0.00\end{array}$ & $\begin{array}{l}0.00 \\
0.00 \\
0.00\end{array}$ & $\begin{array}{l}0.00 \\
0.00 \\
0.00\end{array}$ & $\begin{array}{l}0.00 \\
0.00 \\
0.00\end{array}$ & $\begin{array}{l}1.88 \\
2.47 \\
0.00\end{array}$ \\
\hline$-31.75 F$ & $R+15.83$ & $-1-1 / 4 R+5 / 8$ & $\begin{array}{l}\text { Feed } \\
\text { Overs } \\
\text { Unders }\end{array}$ & $\begin{array}{l}13.20 \\
16.14 \\
.3 .87\end{array}$ & $\begin{array}{l}0.64 \\
0.84 \\
0.00\end{array}$ & $\begin{array}{l}0.00 \\
0.00 \\
0.00\end{array}$ & $\begin{array}{l}0.00 \\
0.00 \\
0.00\end{array}$ & $\begin{array}{l}0.00 \\
0.00 \\
0.00\end{array}$ & $\begin{array}{l}0.00 \\
0.00 \\
0.00\end{array}$ & $\begin{array}{l}0.00 \\
0.00 \\
0.00\end{array}$ & $\begin{array}{r}13.84 \\
16.98 \\
3.87\end{array}$ \\
\hline-15.88 & +1.30 & $-5 / 8+0.051$ & $\begin{array}{l}\text { Feed } \\
\text { Overs } \\
\text { Unders }\end{array}$ & $\begin{array}{l}41.28 \\
38.39 \\
50.46\end{array}$ & $\begin{array}{l}3.97 \\
4.30 \\
2.94\end{array}$ & $\begin{array}{l}0.21 \\
0.19 \\
0.29\end{array}$ & $\begin{array}{l}0.21 \\
0.00 \\
0.89\end{array}$ & $\begin{array}{l}3.19 \\
1.94 \\
7.13\end{array}$ & $\begin{array}{l}0.22 \\
0.10 \\
0.61\end{array}$ & $\begin{array}{l}0.00 \\
0.00 \\
0.00\end{array}$ & $\begin{array}{l}49.08 \\
44.92 \\
62.32\end{array}$ \\
\hline-1.30 & & $-0.05 ?$ & $\begin{array}{l}\text { Feed } \\
\text { Overs } \\
\text { Unders }\end{array}$ & $\begin{array}{l}0.00 \\
0.00 \\
0.00\end{array}$ & $\begin{array}{l}0.00 \\
0.00 \\
0.00\end{array}$ & $\begin{array}{l}0.00 \\
0.00 \\
0.00\end{array}$ & $\begin{array}{l}0.00 \\
0.00 \\
0.00\end{array}$ & $\begin{array}{l}0.00 \\
0.00 \\
0.00\end{array}$ & $\begin{array}{l}0.00 \\
0.00 \\
0.00\end{array}$ & $\begin{array}{r}11.17 \\
4.04 \\
33.81\end{array}$ & $\begin{array}{r}11.17 \\
4.04 \\
33.81\end{array}$ \\
\hline Total & & - & $\begin{array}{l}\text { Feed } \\
\text { Overs } \\
\text { Unders }\end{array}$ & $\begin{array}{l}79.63 \\
87.59 \\
54.33\end{array}$ & $\begin{array}{l}5.37 \\
6.14 \\
2.94\end{array}$ & $\begin{array}{l}0.21 \\
0.19 \\
0.29\end{array}$ & $\begin{array}{l}0.21 \\
0.00 \\
0.89\end{array}$ & $\begin{array}{l}3.19 \\
1.94 \\
7.13\end{array}$ & $\begin{array}{l}0.22 \\
0.10 \\
0.61\end{array}$ & $\begin{array}{r}11.17 \\
4.04 \\
33.81\end{array}$ & $\begin{array}{l}100.00 \\
100.00 \\
100.00\end{array}$ \\
\hline
\end{tabular}

* $\mathbf{R}$ designates round sieve opening. 
TABLE B-6. COMPONENT/SIZE DISTRIBUTION ( 9 rpm, feedrate $=2.82 \mathrm{Mg} / \mathrm{h}(3.10 \mathrm{tons} / \mathrm{h})$, October 1980 ) (\% by weight)

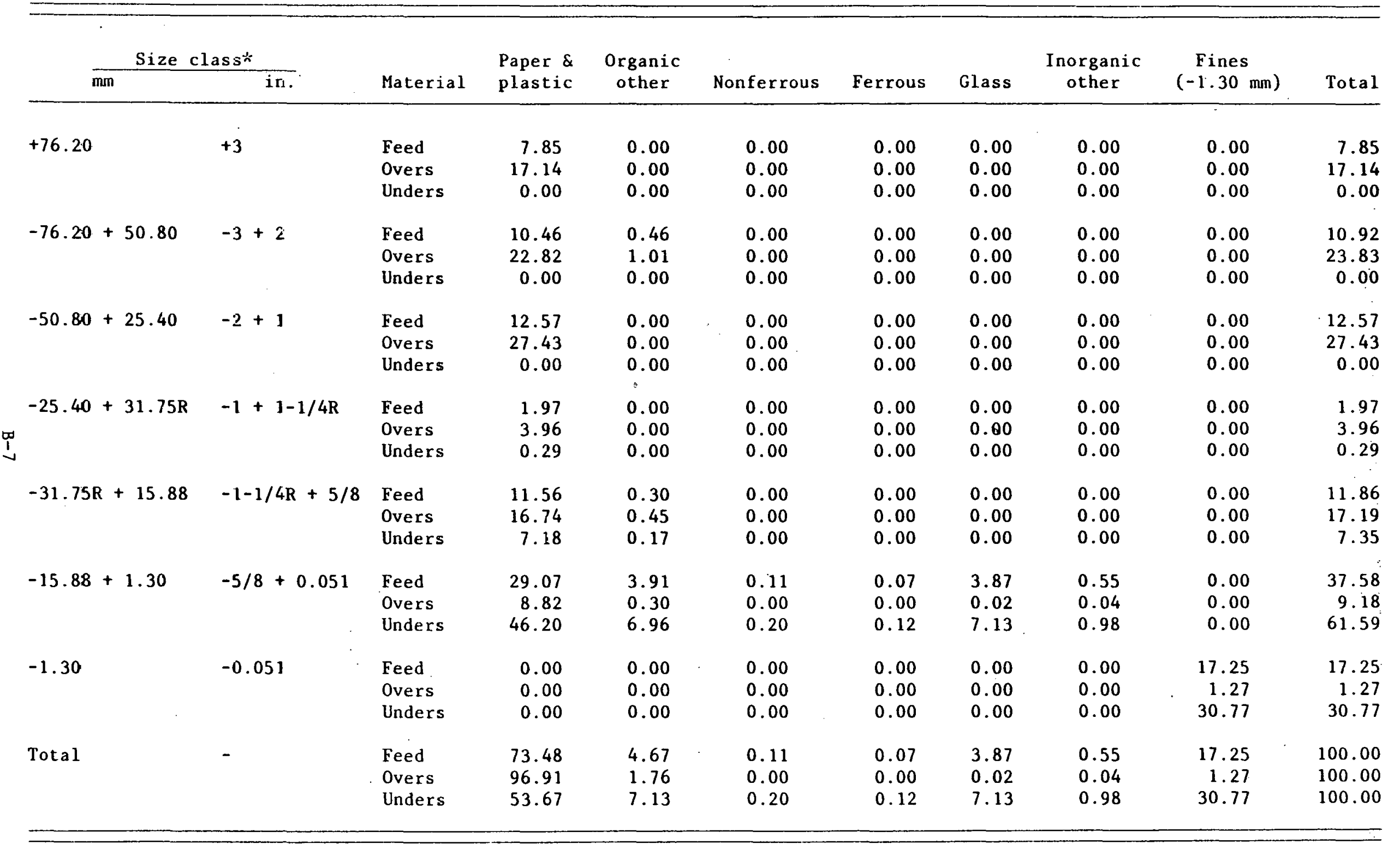

$*$ R designates round sieve opening. 
TABLE B-7. COMPONENT/SIZE DISTREUTION ( $9 \mathrm{rpm}$; feedrate $=5.85 \mathrm{Mg} / \mathrm{h}$ (6.44:tons/h), 0ctober 1980) (\% by weight)

\begin{tabular}{|c|c|c|c|c|c|c|c|c|c|c|}
\hline \multicolumn{2}{|c|}{ Size class ${ }^{-1}$. } & \multirow[b]{2}{*}{ Material } & \multirow{2}{*}{$\begin{array}{l}\text { Paper \& } \\
\text { Plastic }\end{array}$} & \multirow{2}{*}{$\begin{array}{l}\text { Organic } \\
\text { other }\end{array}$} & \multirow[b]{2}{*}{ Nonferrous } & \multirow[b]{2}{*}{ Ferrous } & \multirow[b]{2}{*}{ Glass } & \multirow{2}{*}{$\begin{array}{l}\text { Inorganic } \\
\text { other }\end{array}$} & \multirow{2}{*}{$\begin{array}{l}\text { Fines } \\
(-1.30 \mathrm{~mm})\end{array}$} & \multirow[b]{2}{*}{ Total } \\
\hline .. $\overline{\mathrm{mn}}$ & in. & & & & & & & & & \\
\hline+76.20 & +3 & $\begin{array}{l}\text { Feed } \\
\text { Overs } \\
\text { Unders }\end{array}$ & $\begin{array}{l}2.87 \\
7.53 \\
0.00\end{array}$ & $\begin{array}{l}0.00 \\
0.00 \\
0.00\end{array}$ & $\begin{array}{l}0.00 \\
0.00 \\
0.00\end{array}$ & $\begin{array}{l}0.00 \\
0.00 \\
0.00\end{array}$ & $\begin{array}{l}0.00 \\
0.00 \\
0.00\end{array}$ & $\begin{array}{l}0.00 \\
0.00 \\
0.00\end{array}$ & $\begin{array}{l}0.00 \\
0.00 \\
0.00\end{array}$ & $\begin{array}{l}2.87 \\
7.53 \\
0.00\end{array}$ \\
\hline$-76.20+50.80$ & $-3+2$ & $\begin{array}{l}\text { Feed } \\
\text { Overs } \\
\text { Unders }\end{array}$ & $\begin{array}{r}9.55 \\
25.08 \\
0.00\end{array}$ & $\begin{array}{l}0.00 \\
0.00 \\
0.00\end{array}$ & $\begin{array}{l}0.00 \\
0.00 \\
0.00\end{array}$ & $\begin{array}{l}0.00 \\
0.00 \\
0.00\end{array}$ & $\begin{array}{l}0.00 \\
0.00 \\
0.00\end{array}$ & $\begin{array}{l}0.00 \\
0.00 \\
0.00\end{array}$ & $\begin{array}{l}0.00 \\
0.00 \\
0.00\end{array}$ & $\begin{array}{r}9.55 \\
25.08 \\
0.00\end{array}$ \\
\hline$-50.80+25.40^{\circ}$ & $-2+1$ & $\begin{array}{l}\text { Feed } \\
\text { Overs } \\
\text { Unders }\end{array}$ & $\begin{array}{r}12.16 \\
31.91 \\
0.00\end{array}$ & $\begin{array}{l}0.01 \\
0.04 \\
0.06\end{array}$ & $\begin{array}{l}0.00 \\
0.00 \\
0.00\end{array}$ & $\begin{array}{l}0.00 \\
0.00 \\
0.00\end{array}$ & $\begin{array}{l}0.00 \\
0.00 \\
0.00\end{array}$ & $\begin{array}{l}0.00 \\
0.00 \\
0.00\end{array}$ & $\begin{array}{l}0.00 \\
0.00 \\
0.00\end{array}$ & $\begin{array}{r}12.17 \\
31.95 \\
0.00\end{array}$ \\
\hline$-25.40+31.75 R$ & $-1+1-1,4 \mathrm{R}$ & $\begin{array}{l}\text { Feed } \\
\text { Overs } \\
\text { Unders }\end{array}$ & $\begin{array}{l}1.29 \\
0.50 \\
1.77\end{array}$ & $\begin{array}{l}0.00 \\
0.0 \mathrm{C} \\
0.00\end{array}$ & $\begin{array}{l}0.00 \\
0.00 \\
0.00\end{array}$ & $\begin{array}{l}0.00 \\
0.00 \\
0.00\end{array}$ & $\begin{array}{l}0.00 \\
0.00 \\
0.00\end{array}$ & $\begin{array}{l}0.00 \\
0.00 \\
0.00\end{array}$ & $\begin{array}{l}0.00 \\
0.00 \\
0.00\end{array}$ & $\begin{array}{l}1.29 \\
0.50 \\
1.77\end{array}$ \\
\hline$-31.75 R+15.88$ & $-1-1 / 4 R+5 / 8$ & $\begin{array}{l}\text { Feed } \\
\text { Overs } \\
\text { Unders }\end{array}$ & $\begin{array}{r}13.24 \\
23.60 \\
6.87\end{array}$ & $\begin{array}{l}2.86 \\
1.53 \\
3.68\end{array}$ & $\begin{array}{l}0.00 \\
0.00 \\
0.00\end{array}$ & $\begin{array}{l}0.00 \\
0.00 \\
0.00\end{array}$ & $\begin{array}{l}0.34 \\
0.00 \\
0.54\end{array}$ & $\begin{array}{l}0.00 \\
0.00 \\
0.00\end{array}$ & $\begin{array}{l}0.00 \\
0.00 \\
0.00\end{array}$ & $\begin{array}{l}16.44 \\
25.13 \\
11.09\end{array}$ \\
\hline$-15.88+1.30$ & $-5 / 8+0.051$ & $\begin{array}{l}\text { Feed } \\
\text { Overs } \\
\text { Unders }\end{array}$ & $\begin{array}{r}31.67 \\
7.37 \\
46.64\end{array}$ & $\begin{array}{l}2.06 \\
0.55 \\
2.99\end{array}$ & $\begin{array}{l}0.01 \\
0.00 \\
0.01\end{array}$ & $\begin{array}{l}0.13 \\
0.00 \\
0.20\end{array}$ & $\begin{array}{r}10.48 \\
0.04 \\
16.90\end{array}$ & $\begin{array}{l}2.71 \\
0.00 \\
4.38\end{array}$ & $\begin{array}{l}0.00 \\
0.00 \\
0.00\end{array}$ & $\begin{array}{r}47.06 \\
7.96 \\
71.12\end{array}$ \\
\hline-1.30 & -0.051 & $\begin{array}{l}\text { Feed } \\
\text { Overs } \\
\text { Unders }\end{array}$ & $\begin{array}{l}0.00 \\
0.00 \\
0.00\end{array}$ & $\begin{array}{l}0.00 \\
0.00 \\
0.00\end{array}$ & $\begin{array}{l}0.00 \\
0.00 \\
0.00\end{array}$ & $\begin{array}{l}0.00 \\
0.00 \\
0.00\end{array}$ & $\begin{array}{l}0.00 \\
0.00 \\
0.00\end{array}$ & $\begin{array}{l}0.00 \\
0.00 \\
0.00\end{array}$ & $\begin{array}{r}10.62 \\
1.85 \\
16.02\end{array}$ & $\begin{array}{r}10.62 \\
1.85 \\
16.02\end{array}$ \\
\hline Total. & - & $\begin{array}{l}\text { Feed } \\
\text { Overs } \\
\text { Unders }\end{array}$ & $\begin{array}{l}70.78 \\
95.99 \\
55.28\end{array}$ & $\begin{array}{l}4.93 \\
2.12 \\
6.67\end{array}$ & $\begin{array}{l}0.01 \\
0.00 \\
0.01\end{array}$ & $\begin{array}{l}0.13 \\
0.00 \\
0.20\end{array}$ & $\begin{array}{r}10.82 \\
0.04 \\
17.44\end{array}$ & $\begin{array}{l}2.71 \\
0.00 \\
4.38\end{array}$ & $\begin{array}{r}10.62 \\
1.85 \\
16.02\end{array}$ & $\begin{array}{l}100.00 \\
100.00 \\
100.00\end{array}$ \\
\hline
\end{tabular}

$\stackrel{R}{\circ}$ designates round sieve opening. 
TABLE B-8. COMPONENT/SIZE DISTRIBUTION $(9 \mathrm{rpm}$, feedrate $=10.55 \mathrm{Mg} / \mathrm{h}(11.60 \mathrm{tons} / \mathrm{h})$, October 1980) (\% by weight)

\begin{tabular}{|c|c|c|c|c|c|c|c|c|c|c|}
\hline \multicolumn{2}{|c|}{ Size class* } & \multirow[b]{2}{*}{ Material } & \multirow{2}{*}{$\begin{array}{l}\text { Paper \& } \\
\text { plastic }\end{array}$} & \multirow{2}{*}{$\begin{array}{l}\text { Organic } \\
\text { other }\end{array}$} & \multirow[b]{2}{*}{ Nonferrous } & \multirow[b]{2}{*}{ Ferrous } & \multirow[b]{2}{*}{ Glass } & \multirow{2}{*}{$\begin{array}{c}\text { Inorganic } \\
\text { other }\end{array}$} & \multirow{2}{*}{$\begin{array}{l}\text { Fines } \\
(-1.30 \mathrm{~mm})\end{array}$} & \multirow[b]{2}{*}{ Total } \\
\hline $\mathrm{mm}$ & in. & & & & & & & & & \\
\hline \multirow[t]{3}{*}{+76.20} & +3 & Feed & 14.61 & 0.00 & 0.00 & 0.00 & 0.00 & 0.00 & 0.00 & 14.61 \\
\hline & & Overs & 20.95 & 0.00 & 0.00 & 0.00 & 0.00 & 0.00 & 0.00 & 20.95 \\
\hline & & Unders & 0.00 & 0.00 & 0.00 & 0.00 & 0.00 & 0.00 & 0.00 & 0.00 \\
\hline$-76.20+50.80$ & $-3+2$ & Feed & 13.19 & 0.00 & 0.00 & 0.00 & 0.00 & 0.00 & 0.00 & 13.19 \\
\hline & & Overs & 18.91 & 0.00 & 0.00 & 0.00 & 0.00 & 0.00 & 0.00 & 18.91 \\
\hline & & Unders & 0.00 & 0.00 & 0.00 & 0.00 & 0.00 & 0.00 & 0.00 & 0.00 \\
\hline$-50.80+25.40^{\circ}$ & $-2+1$ & Feed & 14.08 & 0.93 & 0.00 & 0.00 & 0.00 & 0.00 & 0.00 & 15.01 \\
\hline & & Overs & 20.18 & 1.34 & 0.00 & 0.00 & 0.00 & 0.00 & 0.00 & 21.52 \\
\hline . & & Unders & 0.00 & 0.00 & 0.00 & 0.00 & 0.00 & 0.00 & 0.00 & 0.00 \\
\hline$-25.40+31.75 R$ & $-1+1-1 / 4 R$ & Feed & 2.54 & 0.02 & 0.00 & 0.00 & 0.00 & 0.00 & 0.00 & 2.56 \\
\hline & & Overs & 3.41 & 0.02 & 0.00 & 0.00 & 0.00 & 0.00 & 0.00 & 3.43 \\
\hline & & Unders & 0.54 & 0.00 & 0.00 & 0.00 & 0.00 & 0.00 & 0.00 & 0.54 \\
\hline$-31.75 R+15.88$ & $-1-1 / 4 R+5 / 8$ & Feed & 9.82 & 0.11 & 0.00 & 0.00 & 0.00 & 0.00 & 0.00 & 9.93 \\
\hline & & Overs & 12.50 & 0.15 & 0.00 & 0.00 & 0.00 & 0.00 & 0.00 & 12.65 \\
\hline & & Unders & 3.65 & 0.00 & 0.00 & 0.00 & 0.00 & 0.00 & 0.00 & 3.65 \\
\hline$-15.83+1.30$ & $-5 / 8+0.051$ & Feed & 23.78 & 4.00 & 0.04 & 0.00 & 3.39 & 0.77 & 0.00 & 31.98 \\
\hline & & Overs & 16.26 & 2.23 & 0.02 & 0.00 & 0.12 & 0.10 & 0.00 & 18.73 \\
\hline & & Unders & 41.15 & 8.08 & 0.07 & 0.00 & 10.91 & 2.30 & 0.00 & 62.51 \\
\hline \multirow[t]{3}{*}{-1.30} & -0.051 & Feed & 0.00 & 0.00 & 0.00 & 0.00 & 0.00 & 0.00 & 12.72 & 12.72 \\
\hline & & Overs & 0.00 & 0.00 & 0.00 & 0.00 & 0.00 & 0.00 & 3.81 & 3.81 \\
\hline & & Unders & 0.00 & 0.00 & 0.00 & 0.00 & 0.00 & 0.00 & 33.30 & 33.30 \\
\hline \multirow[t]{3}{*}{ Total } & - & Feed & 78.02 & 5.06 & 0.04 & 0.00 & 3.39 & 0.77 & 12.72 & 100.00 \\
\hline & & Overs & 92.21 & 3.74 & 0.02 & 0.00 & 0.12 & 0.10 & 3.81 & 100.00 \\
\hline & & Unders & 45.34 & 8.08 & 0.07 & 0.00 & 10.91 & 2.30 & 33.30 & 100.00 \\
\hline
\end{tabular}

* $\mathrm{R}$ designates round sieve opening. 
TABLE B-9: COMPONENT/SIZE DISTRIBUTION (9 rpm; feedrate $=15.86 \mathrm{Mg} / \mathrm{h}(17.45 \mathrm{tons} / \mathrm{h}$ ), 0ctober 1980) (\% by weight)

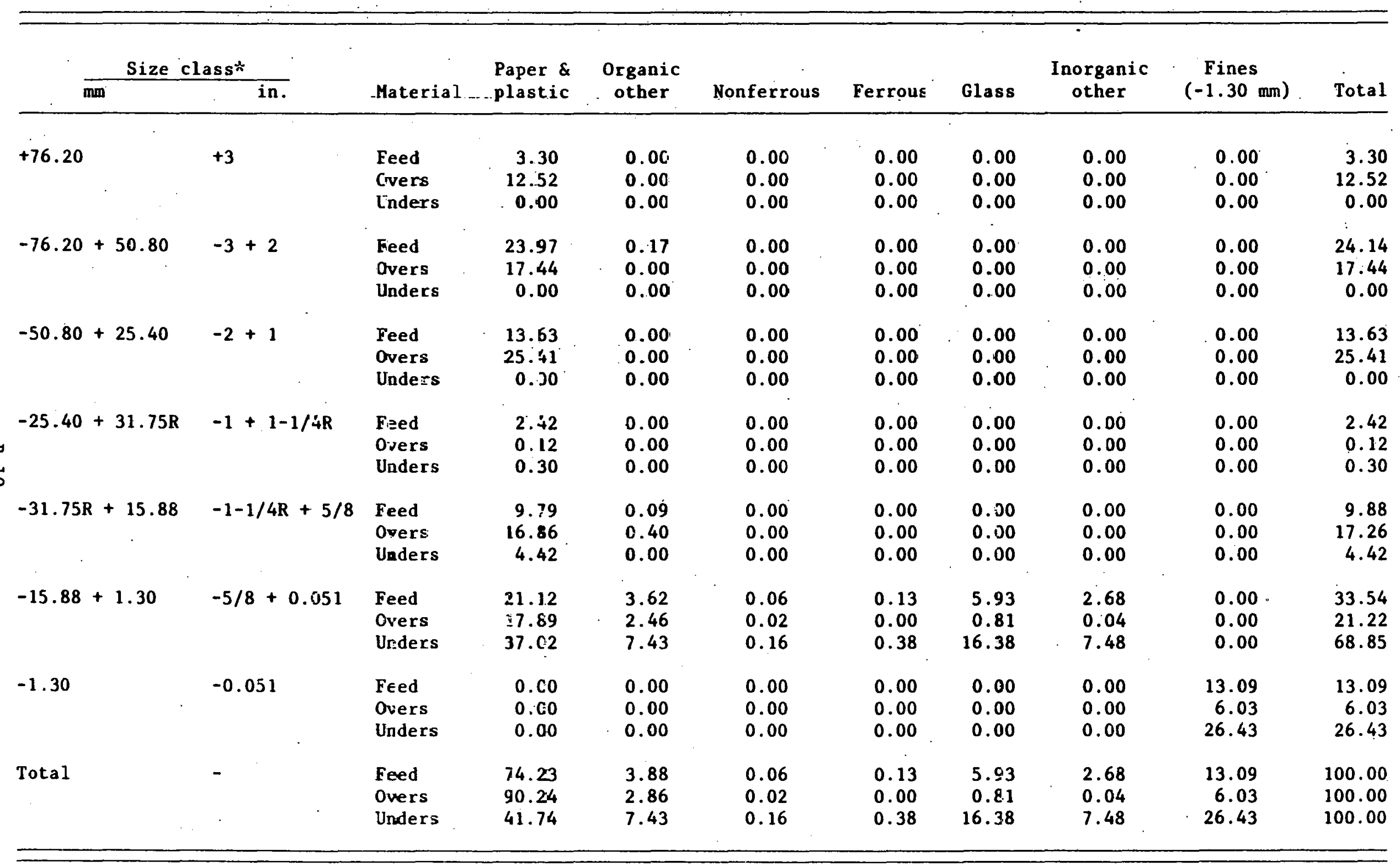

* R designates round sieve spening. 
TABLE B-10. COMPONENT/SIZE DISTRIBUTION $(9 \mathrm{rpm}$, feedrate $=22.55 \mathrm{Mg} / \mathrm{h}(24.80$ tons $/ \mathrm{h})$, October 1980) (\% by weight)

\begin{tabular}{|c|c|c|c|c|c|c|c|c|c|c|c|}
\hline \multirow{3}{*}{\multicolumn{3}{|c|}{$\frac{\text { Size classk }}{\mathrm{mm}}$}} & \multirow[b]{3}{*}{ Material } & \multirow{3}{*}{$\begin{array}{l}\text { Paper } \& \\
\text { plastic }\end{array}$} & \multirow{3}{*}{$\begin{array}{l}\text { Organic } \\
\text { other }\end{array}$} & \multirow[b]{3}{*}{ Nonferrous } & \multirow[b]{3}{*}{ Ferrous } & \multirow[b]{3}{*}{ Glass. } & \multicolumn{2}{|l|}{-} & \multirow[b]{3}{*}{ Total } \\
\hline & & & & & & & & & Inorganic & Fines & \\
\hline & & & & & & & & & other & $(-1.30 \mathrm{~mm})$ & \\
\hline \multirow{3}{*}{\multicolumn{2}{|c|}{+76.20}} & +3 & Feed & 8.01 & 0.00 & 0.00 & 0.00 & 0.00 & 0.00 & 0.00 & 8.01 \\
\hline & & & Overs & 12.52 & 0.00 & 0.00 & 0.00 & 0.00 & 0.00 & 0.00 & 12.52 \\
\hline & & & Unders & 0.00 & 0.00 & 0.00 & 0.00 & 0.00 & 0.00 & 0.00 & 0.00 \\
\hline \multirow[t]{3}{*}{-76.20} & +50.80 & $-3+2$ & Feed & 11.15 & 0.00 & 0.00 & 0.00 & 0.00 & 0.00 & 0.00 & 11.15 \\
\hline & & & Over:s & 17.44 & 0.00 & 0.00 & 0.00 & 0.00 & 0.00 & 0.00 & 17.44 \\
\hline & & & Unders & 0.00 & 0.00 & 0.00 & 0.00 & 0.00 & 0.00 & 0.00 & 0.00 \\
\hline \multirow[t]{3}{*}{-50.80} & +25.40 & $-2+1$ & Feed & 16.25 & 0.00 & 0.00 & 0.00 & 0.00 & 0.00 & 0.00 & 16.25 \\
\hline & & & Overs & 25.41 & 0.00 & 0.00 & 0.00 & 0.00 & 0.00 & 0.00 & 25.41 \\
\hline & & & Unders & 0.00 & 0.00 & 0.00 & 0.00 & 0.00 & 0.00 & 0.00 & 0.00 \\
\hline \multirow{3}{*}{\multicolumn{2}{|c|}{$-25.40+31.75 R$}} & \multirow[t]{3}{*}{$-1+1-1 / 4 R$} & Feed & 0.08 & 0.00 & 0.00 & 0.00 & 0.00 & 0.00 & 0.00 & 0.08 \\
\hline & & & Overs & 0.12 & 0.00 & 0.00 & 0.00 & 0.00 & 0.00 & 0.00 & 0.12 \\
\hline & & & Unders & 0.00 & 0.00 & 0.00 & 0.00 & 0.00 & 0.00 & 0.00 & 0.00 \\
\hline \multirow[t]{3}{*}{$-31.75 R$} & $R+15.88$ & $-1-1 / 4 R+5 / 8$ & Feed & 11.74 & 0.25 & 0.00 & 0.00 & 0.00 & 0.00 & 0.00 & 11.99 \\
\hline & & & Overs & 16.86 & 0.40 & 0.00 & 0.00 & 0.00 & 0.00 & 0.00 & 17.26 \\
\hline & & & Unders & 2.66 & 0.00 & 0.00 & 0.00 & 0.00 & 0.00 & 0.00 & 2.66 \\
\hline \multirow[t]{3}{*}{-15.88} & +1.30 & $-5 / 8+0.051$ & Feed & 26.15 & 2.58 & 0.03 & 0.00 & 9.94 & 0.35 & 0.00 & 39.05 \\
\hline & & & Overs & 17.89 & 2.46 & 0.02 & 0.00 & 0.81 & 0.04 & 0.00 & 21.22 \\
\hline & & & Unders & 40.81 & 2.79 & 0.06 & 0.00 & 26.13 & 0.88 & 0.00 & 70.67 \\
\hline \multirow[t]{3}{*}{-1.30} & & -0.051 & Feed & 0.00 & 0.00 & 0.00 & 0.00 & 0.00 & 0.00 & 13.47 & 13.47 \\
\hline & & & Overs & 0.00 & 0.00 & 0.00 & 0.00 & 0.00 & 0.00 & 6.03 & 6.03 \\
\hline & & & Unders & 0.00 & 0.00 & 0.00 & 0.00 & 0.00 & 0.00 & 26.67 & 26.67 \\
\hline \multirow[t]{3}{*}{ Total } & & - & Feed & 73.38 & 2.83 & 0.03 & 0.00 & 9.94 & 0.35 & 13.47 & 100.00 \\
\hline & & & Overs & 90.24 & 2.86 & 0.02 & 0.00 & 0.81 & 0.04 & 6.03 & 100.00 \\
\hline & & & Unders & 43.47 & 2.79 & 0.06 & 0.00 & 26.13 & 0.88 & 26.67 & 100.00 \\
\hline
\end{tabular}

* $\mathbf{R}$ designates round sieve opening. 
TABLE B-11. COMPONENT/SIZE DISTRIBUTION $(12$ rpm feedrate $=3.43 \mathrm{Mg} / \mathrm{h}$ (3.77 tons/h), 0ctober 1980) ( $\%$ by weight)

\begin{tabular}{|c|c|c|c|c|c|c|c|c|c|c|c|}
\hline & \multicolumn{2}{|c|}{ Size class* } & \multirow[b]{2}{*}{ Material } & \multirow{2}{*}{$\begin{array}{r}\text { Paper \& } \\
\text { - plastic. }\end{array}$} & \multirow{2}{*}{$\begin{array}{c}\text { Organic } \\
\text { other }\end{array}$} & \multirow[b]{2}{*}{ Nonferrous } & \multirow[b]{2}{*}{ Ferrous } & \multirow[b]{2}{*}{ Glass } & \multirow{2}{*}{$\begin{array}{c}\text { Inorganic } \\
\text { other }\end{array}$} & \multirow{2}{*}{$\begin{array}{l}\text { Fines } \\
(-1.30 \mathrm{~mm})\end{array}$} & \multirow[b]{2}{*}{ Total } \\
\hline & $\mathrm{mm}$ & in. & & & & & & & & & \\
\hline+76.20 & & +3 & $\begin{array}{l}\text { Feed } \\
\text { Overs } \\
\text { Unders }\end{array}$ & $\begin{array}{r}8.64 \\
24.31 \\
0.00\end{array}$ & $\begin{array}{l}0.00 \\
0.00 \\
0.00\end{array}$ & $\begin{array}{l}0.00 \\
0.00 \\
0.00\end{array}$ & $\begin{array}{l}0.00 \\
0.00 \\
0.00\end{array}$ & $\begin{array}{l}0.00 \\
0.00 \\
0.00\end{array}$ & $\begin{array}{l}0.00 \\
0.00 \\
0.00\end{array}$ & $\begin{array}{l}0.00 \\
0.00 \\
0.00\end{array}$ & $\begin{array}{r}8.64 \\
24.31 \\
0.00\end{array}$ \\
\hline-76.20 & +50.80 & $-3+2$ & $\begin{array}{l}\text { Feed } \\
\text { Overs } \\
\text { Unders }\end{array}$ & $\begin{array}{r}11.73 \\
33.01 \\
0.00\end{array}$ & $\begin{array}{l}0.00 \\
0.00 \\
0.00\end{array}$ & $\begin{array}{l}0.00 \\
0.00 \\
0.00\end{array}$ & $\begin{array}{l}0.00 \\
0.00 \\
0.00\end{array}$ & $\begin{array}{l}0.00 \\
0.00 \\
0.00\end{array}$ & $\begin{array}{l}0.00 \\
0.00 \\
0.00\end{array}$ & $\begin{array}{l}0.00 \\
0.00 \\
0.00\end{array}$ & $\begin{array}{r}11.73 \\
33.01 \\
0.00\end{array}$ \\
\hline-50.80 & +25.40 & $-2+1$ & $\begin{array}{l}\text { Feed } \\
\text { Overs } \\
\text { Unders }\end{array}$ & $\begin{array}{r}9.46 \\
26.63 \\
0.03\end{array}$ & $\begin{array}{l}0.13 \\
0.37 \\
0.00\end{array}$ & $\begin{array}{l}0.00 \\
0.00 \\
0.00\end{array}$ & $\begin{array}{l}0.0 \mathrm{C} \\
0.0 \mathrm{C} \\
0.0 \mathrm{C}\end{array}$ & $\begin{array}{l}0.00 \\
0.00 \\
0.00\end{array}$ & $\begin{array}{l}0.00 \\
0.00 \\
0.00\end{array}$ & $\begin{array}{l}0.00 \\
0.00 \\
0.00\end{array}$ & $\begin{array}{r}9.59 \\
27.00 \\
0.00\end{array}$ \\
\hline$-25 \cdot 40$ & $+31.75 R$ & $-1+1-1 / 4 R$ & $\begin{array}{l}\text { Feed } \\
\text { Overs } \\
\text { Unders }\end{array}$ & $\begin{array}{l}0.44 \\
1.04 \\
0.11\end{array}$ & $\begin{array}{l}0.00 \\
0.00 \\
0.00\end{array}$ & $\begin{array}{l}0.00 \\
0.00 \\
0.0 \mathrm{C}\end{array}$ & $\begin{array}{l}0.00 \\
0.00 \\
0.00\end{array}$ & $\begin{array}{l}4.67 \\
0.00 \\
7.24\end{array}$ & $\begin{array}{l}0.00 \\
0.00 \\
0.00\end{array}$ & $\begin{array}{l}0.00 \\
0.00 \\
0.00\end{array}$ & $\begin{array}{l}5.11 \\
1.04 \\
7.35\end{array}$ \\
\hline$-31.75 R$ & $R+15.88$ & $-1-1 / 4 R+5 / 8$ & $\begin{array}{l}\text { Feed } \\
\text { Overs } \\
\text { Unders }\end{array}$ & $\begin{array}{l}5.50 \\
8.74 \\
3.72\end{array}$ & $\begin{array}{l}0.26 \\
0.53 \\
0.11\end{array}$ & $\begin{array}{l}0.00 \\
0.00 \\
0.00\end{array}$ & $\begin{array}{l}0.00 \\
0.00 \\
0.00\end{array}$ & $\begin{array}{l}1.06 \\
0.00 \\
1.64\end{array}$ & $\begin{array}{l}5.02 \\
0.00 \\
7.79\end{array}$ & $\begin{array}{l}0.00 \\
0.00 \\
0.00\end{array}$ & $\begin{array}{r}11.84 \\
9.27 \\
13.26\end{array}$ \\
\hline-15.88 & +1.30 & $-5 / 8+0.051$ & $\begin{array}{l}\text { Feed } \\
\text { Overs } \\
\text { Unders }\end{array}$ & $\begin{array}{r}17.73 \\
3.80 \\
25.4 i\end{array}$ & $\begin{array}{l}2.88 \\
0.47 \\
4.21\end{array}$ & $\begin{array}{l}0.03 \\
0.00 \\
0.04\end{array}$ & $\begin{array}{l}0.00 \\
0.00 \\
0.00\end{array}$ & $\begin{array}{r}12.01 \\
0.01 \\
18.62\end{array}$ & $\begin{array}{l}2.78 \\
0.05 \\
4.29\end{array}$ & $\begin{array}{l}0.00 \\
0.00 \\
0.00\end{array}$ & $\begin{array}{r}35.43 \\
4.33 \\
52.57\end{array}$ \\
\hline-1.30 & & -0.051 & $\begin{array}{l}\text { Teed } \\
\text { Dvers } \\
\text { Unders }\end{array}$ & $\begin{array}{l}0.00 \\
0.00 \\
0.00\end{array}$ & $\begin{array}{l}0.00 \\
0.00 \\
0.00\end{array}$ & $\begin{array}{l}0.00 \\
0.00 \\
0.00\end{array}$ & $\begin{array}{l}0.00 \\
0.00 \\
0.00\end{array}$ & $\begin{array}{l}0.00 \\
0.00 \\
0.00\end{array}$ & $\begin{array}{l}0.00 \\
0.00 \\
0.00\end{array}$ & $\begin{array}{r}17.66 \\
1.04 \\
26.82\end{array}$ & $\begin{array}{r}17.66 \\
1.04 \\
26.82\end{array}$ \\
\hline Total & & - & $\begin{array}{l}\text { Feed } \\
\text { Jvers } \\
\text { Unders }\end{array}$ & $\begin{array}{l}53.50 \\
97.53 \\
29.24\end{array}$ & $\begin{array}{l}3.27 \\
1.37 \\
4.32\end{array}$ & $\begin{array}{l}0.03 \\
0.00 \\
0.04\end{array}$ & $\begin{array}{l}0.00 \\
0.00 \\
0.00\end{array}$ & $\begin{array}{r}17.74 \\
0.01 \\
27.50\end{array}$ & $\begin{array}{r}7.80 \\
0.05 \\
12.08\end{array}$ & $\begin{array}{r}17.66 \\
1.04 \\
26.82\end{array}$ & $\begin{array}{l}100.00 \\
100.00 \\
100.00\end{array}$ \\
\hline
\end{tabular}

$\leftarrow$ R designates round sieve opening. 
TABLE E-12. COMPONENT/SIZE DISTRIBUTION $(12 \mathrm{rpm}$, feedrate $=9.11 \mathrm{Mg} / \mathrm{h}(10.02 \mathrm{tons} / \mathrm{h})$, Oclober 1980) (\% by weight)

\begin{tabular}{|c|c|c|c|c|c|c|c|c|c|c|c|}
\hline & \multicolumn{2}{|c|}{ Size class* } & \multirow[b]{2}{*}{ Material } & \multirow{2}{*}{$\begin{array}{l}\text { Paper \& } \\
\text { plastic }\end{array}$} & \multirow{2}{*}{$\begin{array}{l}\text { Organic } \\
\text { other }\end{array}$} & \multirow[b]{2}{*}{ Nonferrous } & \multirow[b]{2}{*}{ Ferrous } & \multirow[b]{2}{*}{ Glass } & \multirow{2}{*}{$\begin{array}{l}\text { Inorganic } \\
\text { other }\end{array}$} & \multirow{2}{*}{$\begin{array}{l}\text { Fines } \\
(-1.30 \mathrm{~mm})\end{array}$} & \multirow[b]{2}{*}{ Total } \\
\hline & $\mathrm{mm}$ & in. & & & & & & & & & \\
\hline \multirow[t]{3}{*}{+76.20} & & +3 & Feed & 9.21 & 0.00 & 0.00 & 0.00 & 0.00 & 0.00 & 0.00 & 9.21 \\
\hline & & & Overs & 14.47 & 0.00 & 0.00 & 0.00 & 0.00 & 0.00 & 0.00 & 14.47 \\
\hline & & & Unders & 0.00 & 0.00 & 0.00 & 0.00 & 0.00 & 0.00 & 0.00 & 0.00 \\
\hline \multirow[t]{3}{*}{-76.20} & +50.80 & $-3+2$ & Feed & 14.01 & 0.00 & 0.00 & 0.00 & 0.00 & 0.00 & 0.00 & 14.01 \\
\hline & & & Overs & 22.01 & 0.00 & 0.00 & 0.00 & 0.00 & 0.00 & 0.00 & 22.01 \\
\hline & & & Unders & 0.00 & 0.00 & 0.00 & 0.00 & 0.00 & 0.00 & 0.00 & 0.00 \\
\hline \multirow[t]{3}{*}{-50.810} & +25.40 & $-i+1$ & Feed & 21.66 & 0.00 & 0.00 & 0.00 & 0.00 & 0.00 & 0.00 & 21.66 \\
\hline & & & Overs & 34.02 & 0.00 & 0.00 & 0.00 & 0.00 & 0.00 & 0.00 & 34.02 \\
\hline & & & Unders & 0.00 & 0.00 & 0.00 & 0.00 & 0.00 & 0.00 & 0.00 & 0.00 \\
\hline \multirow{3}{*}{-25.40} & $+31.75 R$ & $-1+1-1 / 4 R$ & Feed & 1.64 & 0.17 & 0.00 & 0.00 & 0.70 & 0.00 & 0.00 & 2.51 \\
\hline & & & Overs & 2.39 & 0.27 & 0.00 & 0.00 & 0.00 & 0.00 & 0.00 & 2.66 \\
\hline & & & Unders & 0.33 & 0.00 & 0.00 & 0.00 & 1.92 & 0.00 & 0.00 & 2.25 \\
\hline \multirow[t]{3}{*}{$-31.75 R$} & $R+15.88$ & $-i-1 / 4 R+5 / 8$ & Feed & 10.07 & 0.36 & 0.00 & 0.00 & 0.53 & 1.14 & 0.00 & 12.10 \\
\hline & & & Overs & 12.35 & 0.56 & 0.00 & 0.00 & 0.08 & 0.09 & 0.00 & 13.08 \\
\hline & & & Unders & 6.05 & 0.02 & 0.00 & 0.00 & 1.32 & 2.98 & 0.00 & 10.37 \\
\hline \multirow[t]{3}{*}{$-15.8 B$} & +1.30 & $-5 / 8+0.051$ & Feed & 21.90 & 1.55 & 0.03 & 0.00 & 3.69 & 0.21 & 0.00 & 27.38 \\
\hline & & & Overs & 11.60 & 0.33 & 0.00 & 0.00 & 0.00 & 0.00 & 0.00 & 11.93 \\
\hline & & & Unders & 39.96 & 3.68 & 0.07 & 0.00 & 10.16 & 0.59 & 0.00 & 54.46 \\
\hline \multirow[t]{3}{*}{-1.30} & & -0.051 & Feed & 0.00 & 0.00 & 0.00 & 0.00 & 0.00 & 0.00 & 13.13 & 13.13 \\
\hline & & & Overs & 0.00 & 0.00 & 0.00 & 0.00 & 0.00 & 0.00 & 1.83 & 1.83 \\
\hline & & & Unders & 0.00 & 0.00 & 0.00 & 0.00 & 0.00 & 0.00 & 32.92 & 32.92 \\
\hline \multirow[t]{3}{*}{ Total } & & - & Feed & 78.49 & 2.08 & 0.03 & 0.00 & 4.92 & 1.35 & 13.13 & 100.00 \\
\hline & & & Overs & 96.84 & 1.16 & 0.00 & 0.00 & 0.08 & 0.09 & 1.83 & 100.00 \\
\hline & & & Unders & 46.34 & 3.70 & 0.07 & 0.00 & 13.40 & 3.57 & 32.92 & 100.00 \\
\hline
\end{tabular}

$*$ R designates round sieve opening. 
TABLE B-13. COMPONENT/SIZE DISTRIBUTION (12 rpm, feedrate $=13.62 \mathrm{Mg} / \mathrm{h}$ (14.98 tons/h), 0ctober 1980) (\% by weight)

\begin{tabular}{|c|c|c|c|c|c|c|c|c|c|c|c|}
\hline & \multicolumn{2}{|c|}{ Size class } & \multirow[b]{2}{*}{ Material } & \multirow{2}{*}{$\begin{array}{l}\text { Faper \& } \\
\text { p.lastic }\end{array}$} & \multirow{2}{*}{$\begin{array}{l}\text { Organic } \\
\text { other }\end{array}$} & \multirow[b]{2}{*}{ Nonferrous } & \multirow{2}{*}{ Ferrous } & \multirow[b]{2}{*}{ Glass } & \multirow{2}{*}{$\begin{array}{c}\text { Inorganic } \\
\text { other }\end{array}$} & \multirow{2}{*}{$\begin{array}{l}\text { Fines } \\
(-1.30 \mathrm{~mm})\end{array}$} & \multirow[b]{2}{*}{ 'Tota] } \\
\hline & $\mathrm{mm}$ & in. & & & & & & & & & \\
\hline+76.20 & . & +3 & $\begin{array}{l}\text { Feed } \\
\text { Overs } \\
\text { Unders }\end{array}$ & $\begin{array}{l}2.13 \\
4.79 \\
0.00\end{array}$ & $\begin{array}{l}0.00 \\
0.00 \\
0.00\end{array}$ & $\begin{array}{l}0.00 \\
0.00 \\
0.00\end{array}$ & $\begin{array}{l}0.00 \\
0.00 \\
0.00\end{array}$ & $\begin{array}{l}0.00 \\
0.00 \\
0.00\end{array}$ & $\begin{array}{l}0.00 \\
0.00 \\
0.00\end{array}$ & $\begin{array}{l}0.00 \\
0.00 \\
0.00\end{array}$ & $\begin{array}{l}2.13 \\
4.79 \\
0.00\end{array}$ \\
\hline-76.20 & +50.80 & $-3+2$ & $\begin{array}{l}\text { Feed } \\
\text { Orers } \\
\text { Unders }\end{array}$ & $\begin{array}{r}7.17 \\
16.11 \\
0.00\end{array}$ & $\begin{array}{l}0.00 \\
0.00 \\
0.00\end{array}$ & $\begin{array}{l}0.00 \\
0.00 \\
0.00\end{array}$ & $\begin{array}{l}0.00 \\
0.00 \\
0.00\end{array}$ & $\begin{array}{l}0.00 \\
0.00 \\
0.00\end{array}$ & $\begin{array}{l}0.00 \\
0.00 \\
0.00\end{array}$ & $\begin{array}{l}0.00 \\
0.00 \\
0.00\end{array}$ & $\begin{array}{r}7.17 \\
16.11 \\
0.00\end{array}$ \\
\hline-50.80 & +25.40 & $-2+1$ & $\begin{array}{l}\text { Feed } \\
\text { Overs } \\
\text { Uaders }\end{array}$ & $\begin{array}{r}14.99 \\
33.59 \\
0.50\end{array}$ & $\begin{array}{l}0.00 \\
0.00 \\
0.00\end{array}$ & $\begin{array}{l}0.00 \\
0.00 \\
0.00\end{array}$ & $\begin{array}{l}0.00 \\
0.00 \\
0.00\end{array}$ & $\begin{array}{l}0.00 \\
0.00 \\
0.00\end{array}$ & $\begin{array}{l}0.00 \\
0.00 \\
0.00\end{array}$ & $\begin{array}{l}0.00 \\
0.00 \\
0.00\end{array}$ & $\begin{array}{r}14.99 \\
33.69 \\
0.00\end{array}$ \\
\hline-25.40 & $+31.75 R$ & $-1+1-1 / 4 R$ & $\begin{array}{l}\text { Feed } \\
\text { Overs } \\
\text { Unders }\end{array}$ & $\begin{array}{l}3.71 \\
4.51 \\
2.53\end{array}$ & $\begin{array}{l}0.20 \\
0.45 \\
0.00\end{array}$ & $\begin{array}{l}0.00 \\
0.00 \\
0.00\end{array}$ & $\begin{array}{l}0.00 \\
0.00 \\
0.00\end{array}$ & $\begin{array}{l}0.00 \\
0.00 \\
0.00\end{array}$ & $\begin{array}{l}0.00 \\
0.00 \\
0.00\end{array}$ & $\begin{array}{l}0.00 \\
0.00 \\
0.00\end{array}$ & $\begin{array}{l}3.61 \\
4.96 \\
2.53\end{array}$ \\
\hline$-31.75 \mathrm{R}$ & $R+15.88$ & $-1-1 / 4 R+5 / B$ & $\begin{array}{l}\text { Feed } \\
\text { Overs } \\
\text { Unders }\end{array}$ & $\begin{array}{r}9.35 \\
16.79 \\
4.28\end{array}$ & $\begin{array}{l}0.55 \\
1.14 \\
0.08\end{array}$ & $\begin{array}{l}0.00 \\
0.00 \\
0.00\end{array}$ & $\begin{array}{l}0.00 \\
0.00 \\
0.00\end{array}$ & $\begin{array}{l}0.00 \\
0.00 \\
0.00\end{array}$ & $\begin{array}{l}0.00 \\
0.00 \\
0.00\end{array}$ & $\begin{array}{l}0.00 \\
0.00 \\
0.00\end{array}$ & $\begin{array}{r}10.40 \\
17.93 \\
4.36\end{array}$ \\
\hline-15.88 & $3+1.30$ & $-5 / 8+0.051$ & $\begin{array}{l}\text { Feed } \\
\text { Overs } \\
\text { Unders }\end{array}$ & $\begin{array}{l}34.76 \\
17.65 \\
48.49\end{array}$ & $\begin{array}{l}3.20 \\
2.07 \\
4.11\end{array}$ & $\begin{array}{l}0.07 \\
0.00 \\
0.13\end{array}$ & $\begin{array}{l}0.67 \\
0.00 \\
1.20\end{array}$ & $\begin{array}{l}3.67 \\
0.06 \\
6.56\end{array}$ & $\begin{array}{l}0.85 \\
0.07 \\
1.47\end{array}$ & $\begin{array}{l}0.00 \\
0.00 \\
0.00\end{array}$ & $\begin{array}{l}43.22 \\
19.85 \\
61.96\end{array}$ \\
\hline-1.30 & . & -0.051 & $\begin{array}{l}\text { Feed } \\
\text { Overs } \\
\text { Uriders }\end{array}$ & $\begin{array}{l}0.00 \\
0.00 \\
0.00\end{array}$ & $\begin{array}{l}0.00 \\
0.00 \\
0.00\end{array}$ & $\begin{array}{l}0.00 \\
0.00 \\
0.00\end{array}$ & $\begin{array}{l}0.00 \\
0.00 \\
0.00\end{array}$ & $\begin{array}{l}0.00 \\
0.00 \\
0.00\end{array}$ & $\begin{array}{l}0.00 \\
0.00 \\
0.00\end{array}$ & $\begin{array}{r}18.48 \\
2.67 \\
31.15\end{array}$ & $\begin{array}{r}18.48 \\
2.67 \\
31.15\end{array}$ \\
\hline Total & & - & $\begin{array}{l}\text { Feed } \\
\text { Overs } \\
\text { Urders }\end{array}$ & $\begin{array}{l}72.31 \\
93.54 \\
55.30\end{array}$ & $\begin{array}{l}3.95 \\
3.66 \\
4.19\end{array}$ & $\begin{array}{l}0.07 \\
0.00 \\
0.13\end{array}$ & $\begin{array}{l}0.67 \\
0.00 \\
1.20\end{array}$ & $\begin{array}{l}3.67 \\
0.06 \\
6.56\end{array}$ & $\begin{array}{l}0.85 \\
0.07 \\
1.47\end{array}$ & $\begin{array}{r}18.48 \\
2.67 \\
31.15\end{array}$ & $\begin{array}{l}100.00 \\
1.00 .00 \\
100.00\end{array}$ \\
\hline
\end{tabular}

* R designates round sieve opening. 
TABLE B-14. COMPONENT/SIZE DISTRIBUTION $(12 \mathrm{rpm}$, feedrate $=30.27 \mathrm{Mg} / \mathrm{h}(33.30 \mathrm{tons} / \mathrm{h})$, October 1980$)$

(\% by weight)

\begin{tabular}{|c|c|c|c|c|c|c|c|c|c|c|c|}
\hline \multicolumn{3}{|c|}{ Size class } & \multirow[b]{2}{*}{ Material } & \multirow{2}{*}{$\begin{array}{l}\text { Paper \& } \\
\text { plastic }\end{array}$} & \multirow{2}{*}{$\begin{array}{l}\text { Organic } \\
\text { other }\end{array}$} & \multirow[b]{2}{*}{ Nonferrous } & \multirow[b]{2}{*}{ Ferrous } & \multirow[b]{2}{*}{ Glass } & \multirow{2}{*}{$\begin{array}{c}\text { Inorganic } \\
\text { other }\end{array}$} & \multirow{2}{*}{$\begin{array}{l}\text { Fines } \\
(-1.30 \mathrm{~mm})\end{array}$} & \multirow[b]{2}{*}{ Total } \\
\hline & $\mathrm{mm}$ & in. & & & & & & & & & \\
\hline \multirow[t]{3}{*}{+76.20} & & +3 & Feed & 8.48 & 0.00 & 0.00 & 0.00 & 0.00 & 0.00 & 0.00 & 8.48 \\
\hline & & & Overs & 12.38 & 0.00 & 0.00 & 0.00 & 0.00 & 0.00 & 0.00 & 12.38 \\
\hline & & & Unders & 0.00 & 0.00 & 0.00 & 0.00 & 0.00 & 0.00 & 0.00 & 0.00 \\
\hline \multirow[t]{3}{*}{-76.20} & +50.80 & $-3+2$ & Feed & 11.41 & 0.00 & 0.00 & 0.00 & 0.00 & 0.00 & 0.00 & 11.41 \\
\hline & & & Overs & 16.66 & 0.00 & 0.00 & 0.00 & 0.00 & 0.00 & 0.00 & 16.66 \\
\hline & & & Unders & 0.00 & 0.00 & 0.00 & 0.00 & 0.00 & 0.00 & 0.00 & 0.00 \\
\hline \multirow[t]{3}{*}{-50.80} & +25.40 & $-2+1$ & Feed & 15.51 & 0.00 & 0.00 & 0.00 & 0.00 & 0.00 & 0.00 & 15.51 \\
\hline & & & Overs & 22.64 & 0.00 & 0.00 & 0.00 & 0.00 & 0.00 & 0.00 & 22.64 \\
\hline & & & Unders & 0.00 & 0.00 & 0.00 & 0.00 & 0.00 & 0.00 & 0.00 & 0.00 \\
\hline \multirow{3}{*}{-25.40} & $+31.75 R$ & $-1+1-1 / 4 R$ & Feed & 1.84 & 0.00 & 0.00 & 0.00 & 0.00 & 0.00 & 0.00 & 1.84 \\
\hline & & & Overs & 2.69 & 0.00 & 0.00 & 0.00 & 0.00 & 0.00 & 0.00 & 2.69 \\
\hline & & & Unders & 0.00 & 0.00 & 0.00 & 0.00 & 0.00 & 0.00 & 0.00 & 0.00 \\
\hline \multirow[t]{3}{*}{$-31.75 R$} & $R+15.88$ & $-1-1 / 4 R+5 / 8$ & Feed & 12.12 & 0.65 & 0.00 & 0.00 & 0.00 & 0.00 & 0.00 & 12.77 \\
\hline & & & Overs & 16.33 & 0.27 & 0.00 & 0.00 & 0.00 & 0.00 & 0.00 & 16.60 \\
\hline & & & Unders & 2.95 & 1.48 & 0.00 & 0.00 & 0.00 & 0.00 & 0.00 & 4.43 \\
\hline \multirow[t]{3}{*}{$-15.8 .8$} & +1.30 & $-5 / 8+0.051$ & Feed & 24.34 & 2.55 & 0.21 & 0.26 & 3.78 & 0.32 & 0.00 & 31.46 \\
\hline & & & Overs & 17.82 & 2.62 & 0.09 & 0.38 & 0.34 & 0.07 & 0.00 & 21.32 \\
\hline & & & Unders & 38.54 & 2.37 & 0.46 & 0.00 & 11.27 & 0.87 & 0.00 & 53.51 \\
\hline \multirow[t]{3}{*}{-1.30} & & -0.051 & Feed & 0.00 & 0.00 & 0.00 & 0.00 & 0.00 & 0.00 & 18.53 & 18.53 \\
\hline & & & Overs & 0.00 & 0.00 & 0.00 & 0.00 & 0.00 & 0.00 & 7.71 & 7.71 \\
\hline & & & Unders & 0.00 & 0.00 & 0.00 & 0.00 & 0.00 & 0.00 & 42.06 & 42.06 \\
\hline \multirow[t]{3}{*}{ Total } & & - & Feed & 73.70 & 3.20 & 0.21 & 0.26 & 3.78 & 0.32 & 18.53 & 100.00 \\
\hline & & & Overs & 88.52 & 2.89 & 0.09 & 0.38 & 0.34 & 0.07 & 7.71 & 100.00 \\
\hline & & & Unders & 41.49 & 3.85 & 0.46 & 0.00 & 11.27 & 0.87 & 42.06 & 100.00 \\
\hline
\end{tabular}

* $\mathbb{R}$ designates round sieve opening. 
TABLE B-15. COMPONENT/SIZE DISTRIBLTION (12 $\mathrm{rpm}$, feedrate $=38.52 \mathrm{Mg} / \mathrm{h}(42.37$ tons $/ \mathrm{h}), 0 \mathrm{ctober}$ 1980) (\% by weight)

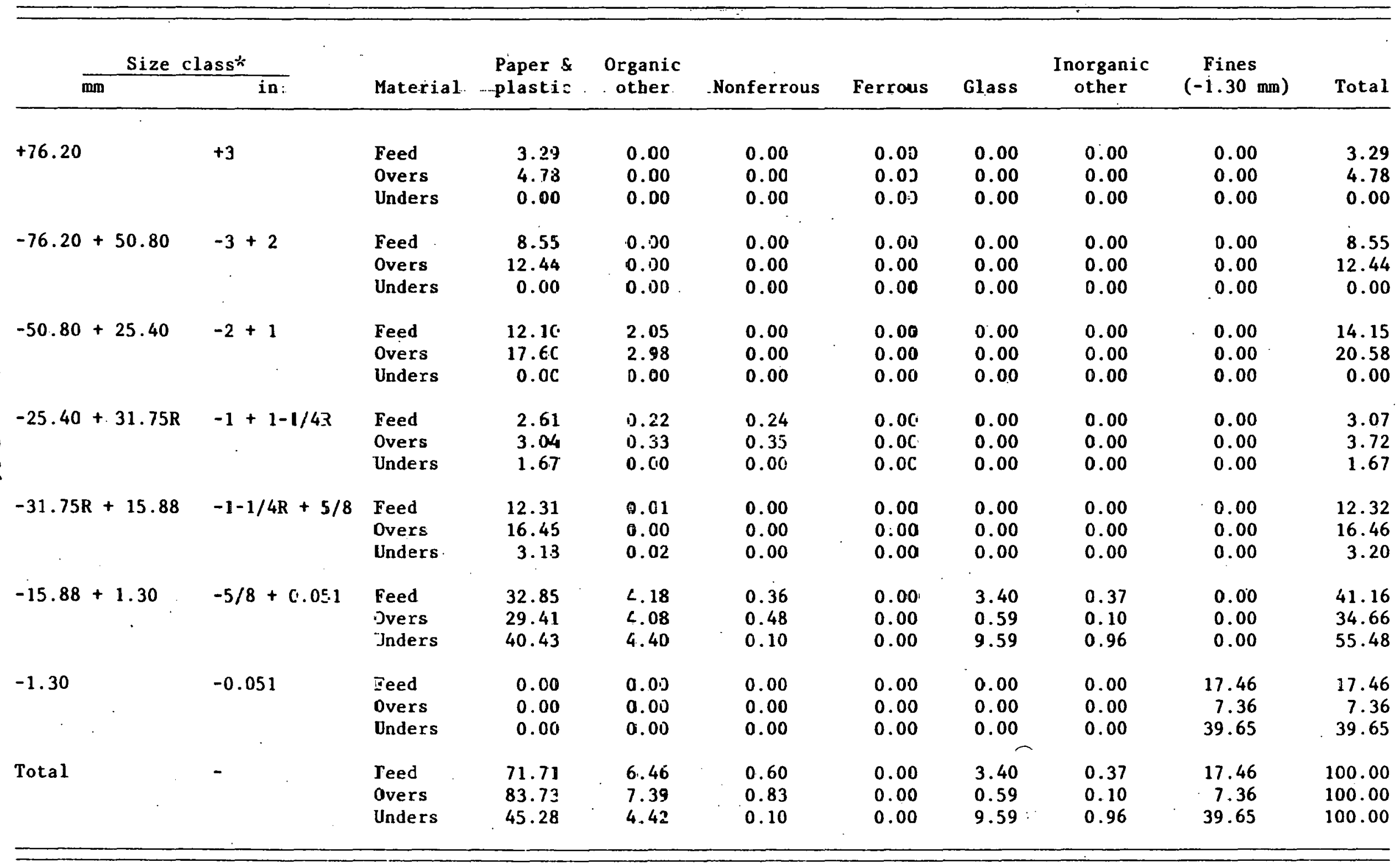

* R designates round sieve opening. 
TABLE B-15. COMPONENT/SIZE DISTRIBUTION (6 rpm, feedrate $=0.96 \mathrm{Mg} / \mathrm{h}(1.06$ tons $/ \mathrm{h}$ ), January 1981) (\% by weight)

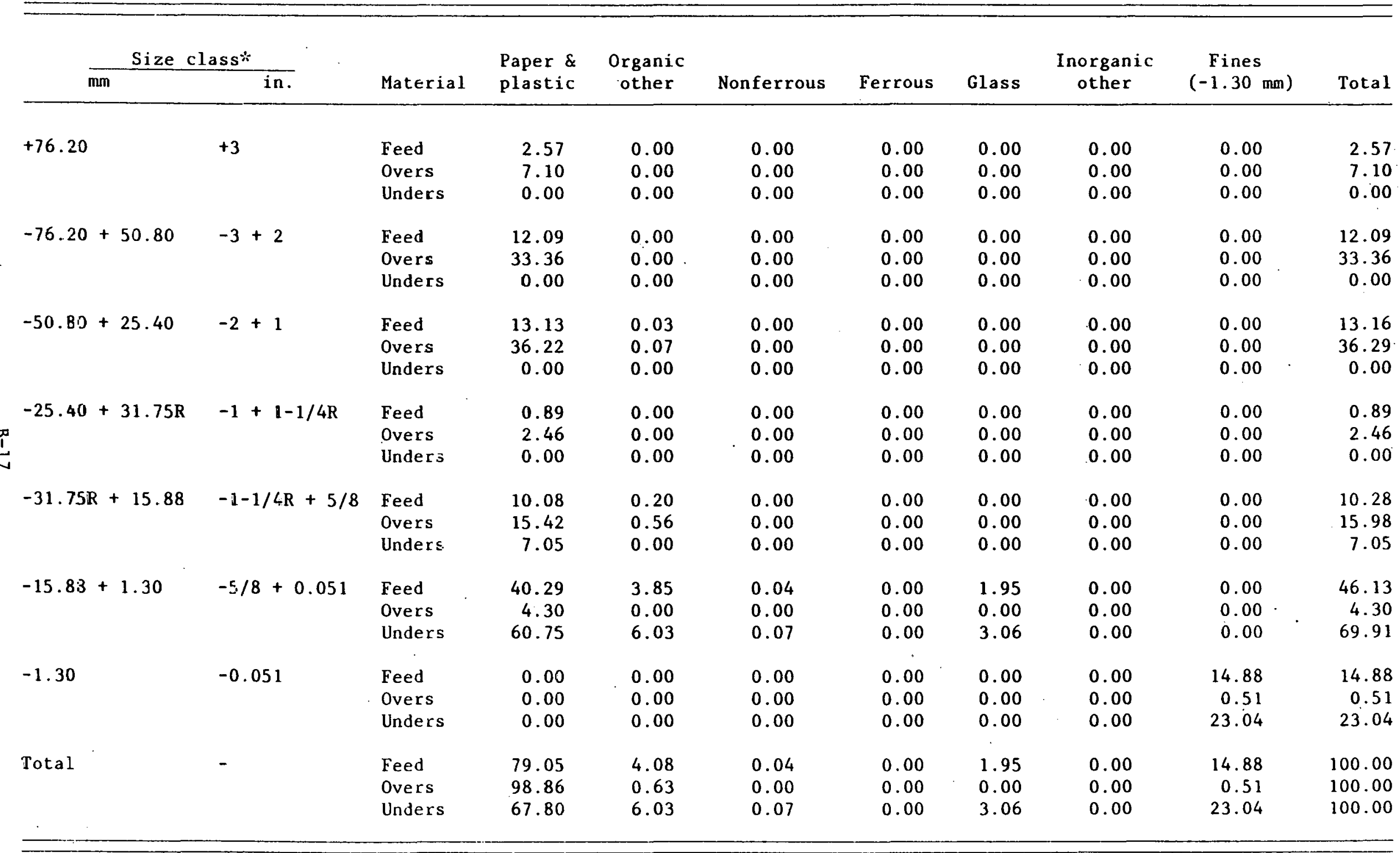

* R designates round sieve opening. 
TABLE B-17. COMPONENT/SIZE DISTRIBUTION (6 rpm, feedrate $=2.97 \mathrm{Mg} / \mathrm{h}$ (3.27 tons $/ \mathrm{h}$ ), January 1981)

(\% by weight)

\begin{tabular}{|c|c|c|c|c|c|c|c|c|c|c|c|}
\hline & \multicolumn{2}{|c|}{ Size class* } & \multirow[b]{2}{*}{ Material } & \multirow{2}{*}{$\begin{array}{l}\text { Eaper \& } \\
\text { flastic }\end{array}$} & \multirow{2}{*}{$\begin{array}{l}\text { Organic } \\
\text { other }\end{array}$} & \multirow[b]{2}{*}{ Nonferrous } & \multirow[b]{2}{*}{ Ferrous } & \multirow[b]{2}{*}{ Glaṣs } & \multirow{2}{*}{$\begin{array}{c}\text { Inorganic } \\
\text { other }\end{array}$} & \multirow{2}{*}{$\begin{array}{l}\text { Fines } \\
(-1.30 \mathrm{~mm})\end{array}$} & \multirow[b]{2}{*}{ Total } \\
\hline & $\overline{\mathrm{mm}}$ & $\overline{\text { in. }}$ & & & & & & & & & \\
\hline+76.20 & & +3 & $\begin{array}{l}\text { Feed } \\
\text { Overs } \\
\text { Unders }\end{array}$ & $\begin{array}{r}15.51 \\
29.65 \\
0.00\end{array}$ & $\begin{array}{l}0.00 \\
0.00 \\
0.00\end{array}$ & $\begin{array}{l}0.00 \\
0.00 \\
0.00\end{array}$ & $\begin{array}{l}0.00 \\
0.00 \\
0.00\end{array}$ & $\begin{array}{l}0.00 \\
0.00 \\
0.00\end{array}$ & $\begin{array}{l}0.00 \\
0.00 \\
0.00\end{array}$ & $\begin{array}{l}0.00 \\
0.00 \\
0.00\end{array}$ & $\begin{array}{r}15.51 \\
29.65 \\
0.00\end{array}$ \\
\hline-76.20 & +50.80 & $-3+2$ & $\begin{array}{l}\text { Feed } \\
\text { Overs } \\
\text { Unders }\end{array}$ & $\begin{array}{r}16.51 \\
31.56 \\
0.00\end{array}$ & $\begin{array}{l}0.07 \\
0.14 \\
0.00\end{array}$ & $\begin{array}{l}0.00 \\
0.00 \\
0.00\end{array}$ & $\begin{array}{l}0.00 \\
0.00 \\
0.00\end{array}$ & $\begin{array}{l}0.00 \\
0.00 \\
0.00\end{array}$ & $\begin{array}{l}0.00 \\
0.00 \\
0.00\end{array}$ & $\begin{array}{l}0.00 \\
0.00 \\
0.00\end{array}$ & $\begin{array}{r}16.58 \\
31.70 \\
0.00\end{array}$ \\
\hline-50.80 & +25.40 & $-2+1$ & $\begin{array}{l}\text { Feed } \\
\text { Overs } \\
\text { Unders }\end{array}$ & $\begin{array}{r}7.80 \\
14.92 \\
0.00\end{array}$ & $\begin{array}{l}0.00 \\
0.00 \\
0.00\end{array}$ & $\begin{array}{l}0.00 \\
0.00 \\
0.00\end{array}$ & $\begin{array}{l}0.00 \\
0.00 \\
0.00\end{array}$ & $\begin{array}{l}0.00 \\
0.00 \\
0.00\end{array}$ & $\begin{array}{l}0.00 \\
0.00 \\
0.00\end{array}$ & $\begin{array}{l}0.00 \\
0.00 \\
0.00\end{array}$ & $\begin{array}{r}7.80 \\
14.92 \\
0.00\end{array}$ \\
\hline-25.40 & $+31.75 R$ & $-1+1-1 / 4 \mathrm{~B}$ & $\begin{array}{l}\text { Feed } \\
\text { Overs } \\
\text { Unders }\end{array}$ & $\begin{array}{l}1.49 \\
2.84 \\
0.00\end{array}$ & $\begin{array}{l}0.00 \\
0.00 \\
0.00\end{array}$ & $\begin{array}{l}0.00 \\
0.00 \\
0.00\end{array}$ & $\begin{array}{l}0.00 \\
0.00 \\
0.00\end{array}$ & $\begin{array}{l}0.00 \\
0.00 \\
0.00\end{array}$ & $\begin{array}{l}0.00 \\
0.00 \\
0.00\end{array}$ & $\begin{array}{l}0.00 \\
0.00 \\
0.00\end{array}$ & $\begin{array}{l}1.49 \\
2.84 \\
0.00\end{array}$ \\
\hline$-31.75 F$ & $R+15.88$ & $-1-1 / 4 R+5 / 8$ & $\begin{array}{l}\text { Feed } \\
\text { Overs } \\
\text { Unders }\end{array}$ & $\begin{array}{r}7.03 \\
11.05 \\
2.63\end{array}$ & $\begin{array}{l}0.02 \\
0.03 \\
0.00\end{array}$ & $\begin{array}{l}0.00 \\
0.00 \\
0.00\end{array}$ & $\begin{array}{l}0.00 \\
0.00 \\
0.00\end{array}$ & $\begin{array}{l}0.00 \\
0.00 \\
0.00\end{array}$ & $\begin{array}{l}0.00 \\
0.00 \\
0.00\end{array}$ & $\begin{array}{l}0.00 \\
0.00 \\
0.00\end{array}$ & $\begin{array}{r}7.05 \\
11.08 \\
2.63\end{array}$ \\
\hline-15.88 & +1.30 & $-5 / 8+0.0 .51$ & $\begin{array}{l}\text { Feed } \\
\text { Overs } \\
\text { Unders }\end{array}$ & $\begin{array}{r}27.86 \\
8.36 \\
49.28\end{array}$ & $\begin{array}{l}1.52 \\
0.18 \\
3.00\end{array}$ & $\begin{array}{l}0.46 \\
0.43 \\
0.49\end{array}$ & $\begin{array}{l}0.03 \\
0.05 \\
0.00\end{array}$ & $\begin{array}{r}7.54 \\
0.00 \\
15.81\end{array}$ & $\begin{array}{l}0.61 \\
0.09 \\
1.16\end{array}$ & $\begin{array}{l}0.00 \\
0.00 \\
0.00\end{array}$ & $\begin{array}{r}38.02 \\
9.11 \\
69.74\end{array}$ \\
\hline$-1: 30$ & . & -0.051 & $\begin{array}{l}\text { Feed } \\
\text { Overs } \\
\text { Unders }\end{array}$ & $\begin{array}{l}0.00 \\
0.00 \\
0.00\end{array}$ & $\begin{array}{l}0.00 \\
0.00 \\
0.00\end{array}$ & $\begin{array}{l}0.00 \\
0.00 \\
0.00\end{array}$ & $\begin{array}{l}0.00 \\
0.01 \\
0.00\end{array}$ & $\begin{array}{l}0.00 \\
0.00 \\
0.00\end{array}$ & $\begin{array}{l}0.00 \\
0.00 \\
0.00\end{array}$ & $\begin{array}{r}13.55 \\
0.70 \\
27.63\end{array}$ & $\begin{array}{r}13.55 \\
0.70 \\
27.63\end{array}$ \\
\hline Total & & - & $\begin{array}{l}\text { Feed } \\
\text { Overs } \\
\text { Unders }\end{array}$ & $\begin{array}{l}76.20 \\
98.33 \\
51.91\end{array}$ & $\begin{array}{l}1.61 \\
0.35 \\
3.00\end{array}$ & $\begin{array}{l}0.46 \\
0.43 \\
0.49\end{array}$ & $\begin{array}{l}0.03 \\
0.05 \\
0.00\end{array}$ & $\begin{array}{r}7.54 \\
0.00 \\
15.81\end{array}$ & $\begin{array}{l}0.61 \\
0.09 \\
1.16\end{array}$ & $\begin{array}{r}13.55 \\
0.70 \\
27.63\end{array}$ & $\begin{array}{l}100.00 \\
100.00 \\
100.00\end{array}$ \\
\hline
\end{tabular}

* R designatës round sieve opening. 
TABLE B-18. COMPONENT/SIZE DISTRIBUTION $(6 \mathrm{rpm}$, feedrate $=5.58 \mathrm{Mg} / \mathrm{h}(6.14$ tons $/ \mathrm{h})$, January 1981) (\% by weight)

\begin{tabular}{|c|c|c|c|c|c|c|c|c|c|c|c|}
\hline & \multicolumn{2}{|c|}{ Size class $*$} & \multirow[b]{2}{*}{ Material } & \multirow{2}{*}{$\begin{array}{l}\text { Paper \& } \\
\text { plastic }\end{array}$} & \multirow{2}{*}{$\begin{array}{c}\text { Organic } \\
\text { other }\end{array}$} & \multirow[b]{2}{*}{ Nonferrous } & \multirow[b]{2}{*}{ Ferrous } & \multirow[b]{2}{*}{ Glass } & \multirow{2}{*}{$\begin{array}{l}\text { Inorganic } \\
\text { other }\end{array}$} & \multirow{2}{*}{$\begin{array}{l}\text { Fines } \\
(-1.30 \mathrm{~mm})\end{array}$} & \multirow[b]{2}{*}{ Total } \\
\hline & $\mathrm{mm}$ & in. & & & & & & & & & \\
\hline \multirow[t]{3}{*}{+76.20} & & +3 & Feed & 6.00 & 0.24 & 0.00 & 0.00 & 0.00 & 0.00 & 0.00 & 6.24 \\
\hline & & & Overs & 8.60 & 0.34 & 0.00 & 0.00 & 0.00 & 0.00 & 0.00 & 8.94 \\
\hline & & & Unders & 0.00 & 0.00 & 0.00 & 0.00 & 0.00 & 0.00 & 0.00 & 0.00 \\
\hline \multirow[t]{3}{*}{-76.20} & +50.80 & $-3+2$ & Feed & 22.46 & 1.56 & 0.00 & 0.00 & 0.00 & 0.00 & 0.00 & 24.02 \\
\hline & & & Overs & 32.16 & 2.24 & 0.00 & 0.00 & 0.00 & 0.00 & 0.00 & 34.40 \\
\hline & & & Unders & 0.00 & 0.00 & 0.00 & 0.00 & 0.00 & 0.00 & 0.00 & 0.00 \\
\hline \multirow[t]{3}{*}{-50.80} & +25.40 & $-2+1$ & Feed & 11.98 & 0.63 & 0.00 & 0.00 & 0.00 & 0.00 & 0.00 & 12.61 \\
\hline & & & Overs & 17.16 & 0.90 & 0.00 & 0.00 & 0.00 & 0.00 & 0.00 & 18.06 \\
\hline & & & Unders & 0.00 & 0.00 & 0.00 & 0.00 & 0.00 & 0.00 & 0.00 & 0.00 \\
\hline \multirow[t]{3}{*}{-25.40} & $+31.75 R$ & $-1+1-1 / 4 R$ & Feed & 1.68 & 0.14 & 0.00 & 0.00 & 0.00 & 0.00 & 0.00 & 1.82 \\
\hline & & & Overs & 2.41 & 0.20 & 0.00 & 0.00 & 0.00 & 0.00 & 0.00 & 2.61 \\
\hline & & & Unders & 0.00 & 0.00 & 0.00 & 0.00 & 0.00 & $\therefore 0.00$ & 0.00 & 0.00 \\
\hline \multirow[t]{3}{*}{$-3 i .75 R$} & $R+15.88$ & $-1-1 / 4 R+5 / 8$ & Feed & 9.72 & 0.68 & 1.01 & 0.00 & 0.00 & -0.00 & 0.00 & 11.41 \\
\hline & & & Overs & 12.76 & 0.38 & 1.45 & 0.00 & 0.00 & 0.00 & 0.00 & 14.59 \\
\hline & & & Unders & 2.69 & 1.39 & 0.00 & 0.00 & 0.00 & 0.00 & 0.00 & 4.08 \\
\hline \multirow[t]{3}{*}{-15.88} & +1.30 & $-5 / B+0.051$ & Feed & 21.96 & 6.38 & 0.03 & 0.00 & 4.53 & 0.48 & 0.00 & 33.37 \\
\hline & & & Overs & 14.51 & 4.05 & 0.03 & 0.00 & 0.47 & 0.10 & 0.00 & 19.16 \\
\hline & & & Unders & 39.21 & 11.74 & 0.02 & 0.00 & 13.95 & 1.34 & 0.00 & 66.26 \\
\hline \multirow[t]{3}{*}{-1.30} & & -0.051 & Feed & 0.00 & 0.00 & 0.00 & 0.00 & 0.00 & 0.00 & 10.52 & 10.52 \\
\hline & & & Overs & 0.00 & 0.00 & 0.00 & 0.00 & 0.00 & 0.00 & 2.24 & 2.24 \\
\hline & & & Unders & 0.00 & 0.00 & 0.00 & 0.00 & 0.00 & 0.00 & 29.66 & 29.66 \\
\hline \multirow[t]{3}{*}{ Total } & & - & Feed & 73.80 & 9.63 & 1.04 & 0.00 & 4.53 & 0.48 & $10 . .52$ & 100.00 \\
\hline & & & Overs & 87.60 & 8.11 & 1.48 & 0.00 & 0.47 & 0.10 & 2.24 & 100.00 \\
\hline & & & Unders & 41.90 & 13.13 & 0.02 & 0.00 & 13.95 & 1.34 & 29.66 & 100.00 \\
\hline
\end{tabular}

* $\mathbf{R}$ designates round sieve opening. 
TABLE B-19. COMPONENT/SIZE DISTRIBUTION $(6 \mathrm{rpm}$, feedrate $=9.62 \mathrm{Mg} / \mathrm{h}(10.58$ tons $/ \mathrm{h})$, January 1981) ( $($ by weight)

\begin{tabular}{|c|c|c|c|c|c|c|c|c|c|c|c|}
\hline \multirow[b]{2}{*}{$\ldots \ldots$} & \multicolumn{2}{|c|}{ Size class $*$} & \multirow[b]{2}{*}{ Material } & \multirow{2}{*}{$\begin{array}{r}\text { Paper \& } \\
\text { plastic. }\end{array}$} & \multirow{2}{*}{$\begin{array}{c}\text { Organic } \\
\text { other }\end{array}$} & \multirow[b]{2}{*}{ Nonferrous } & \multirow[b]{2}{*}{ Ferrous } & \multirow[b]{2}{*}{ Glass } & \multirow{2}{*}{$\begin{array}{c}\text { Inorganic } \\
\text { other }\end{array}$} & \multirow{2}{*}{$\begin{array}{l}\text { Fines } \\
(-1.30 \mathrm{~mm})\end{array}$} & \multirow[b]{2}{*}{ Total } \\
\hline & $\mathrm{mm}$ & in. & & & & & & & & & \\
\hline+76.20 & & +3 & $\begin{array}{l}\text { Feed } \\
\text { Overs } \\
\text { Unders }\end{array}$ & $\begin{array}{r}7.81 \\
10.17 \\
0.00\end{array}$ & $\begin{array}{l}0.94 \\
1.22 \\
0.00\end{array}$ & $\begin{array}{l}0.00 \\
0.00 \\
0.00\end{array}$ & $\begin{array}{l}0.00 \\
0.00 \\
0.00\end{array}$ & $\begin{array}{l}0.00 \\
0.00 \\
0.00\end{array}$ & $\begin{array}{l}0.00 \\
0.00 \\
0.00\end{array}$ & $\begin{array}{l}0.00 \\
0.00 \\
0.00\end{array}$ & $\begin{array}{r}8.75 \\
11.39 \\
0.00\end{array}$ \\
\hline-76.20 & +50.80 & $-3+2$ & $\begin{array}{l}\text { Feed } \\
\text { Overs } \\
\text { Unders }\end{array}$ & $\begin{array}{r}27.81 \\
36.23 \\
0.00\end{array}$ & $\begin{array}{l}0.07 \\
0.09 \\
0.00\end{array}$ & $\begin{array}{l}0.00 \\
0.00 \\
0.00\end{array}$ & $\begin{array}{l}0.00 \\
0.00 \\
0.00\end{array}$ & $\begin{array}{l}0.00 \\
0.00 \\
0.00\end{array}$ & $\begin{array}{l}0.00 \\
0.00 \\
0.00\end{array}$ & $\begin{array}{l}0.00 \\
0.00 \\
0.00\end{array}$ & $\begin{array}{r}27.88 \\
36.32 \\
0.00\end{array}$ \\
\hline-50.80 & +25.40 & $-2+1$ & $\begin{array}{l}\text { Feed } \\
\text { Overs } \\
\text { Unders }\end{array}$ & $\begin{array}{r}10.86 \\
14.15 \\
0.00\end{array}$ & $\begin{array}{l}0.00 \\
0.00 \\
0.00\end{array}$ & $\begin{array}{l}0.00 \\
0.00 \\
0.00\end{array}$ & $\begin{array}{l}0.00 \\
0.00 \\
0.00\end{array}$ & $\begin{array}{l}0.00 \\
0.00 \\
0.00\end{array}$ & $\begin{array}{l}0.00 \\
0.00 \\
0.00\end{array}$ & $\begin{array}{l}0.00 \\
0.00 \\
0.00\end{array}$ & $\begin{array}{r}10.86 \\
14.15 \\
0.00\end{array}$ \\
\hline-25.40 & $+31.75 R$ & $-1+1-1 / 4 R$ & $\begin{array}{l}\text { Feed } \\
\text { Overs } \\
\text { Jnders }\end{array}$ & $\begin{array}{l}2.01 \\
2.62 \\
0.00\end{array}$ & $\begin{array}{l}0.02 \\
0.02 \\
0.00\end{array}$ & $\begin{array}{l}0.00 \\
0.00 \\
0.00\end{array}$ & $\begin{array}{l}0.00 \\
0.00 \\
0.00\end{array}$ & $\begin{array}{l}0.00 \\
0.00 \\
0.00\end{array}$ & $\begin{array}{l}0.00 \\
0.00 \\
0.00\end{array}$ & $\begin{array}{l}0.00 \\
0.00 \\
0.00\end{array}$ & $\begin{array}{l}2.03 \\
2.64 \\
0.00\end{array}$ \\
\hline$-31.75 F$ & $R+15.88$ & $-1-1 / 4 R+5 / 8$ & $\begin{array}{l}\text { Feed } \\
\text { crvers } \\
\text { Unders }\end{array}$ & $\begin{array}{r}9.43 \\
11.64 \\
2.12\end{array}$ & $\begin{array}{l}0.05 \\
0.07 \\
0.00\end{array}$ & $\begin{array}{l}0.00 \\
0.00 \\
0.00\end{array}$ & $\begin{array}{l}0.00 \\
0.00 \\
0.00\end{array}$ & $\begin{array}{l}0.00 \\
0.00 \\
0.00\end{array}$ & $\begin{array}{l}0.00 \\
0.00 \\
0.00\end{array}$ & $\begin{array}{l}0.00 \\
0.00 \\
0.00\end{array}$ & $\begin{array}{r}9.48 \\
11.71 \\
2.12\end{array}$ \\
\hline-15.88 & +1.30 & $-5 / 8+0.051$ & $\begin{array}{l}\text { Feed } \\
\text { Overs } \\
\text { Unders }\end{array}$ & $\begin{array}{l}18.23 \\
14.60 \\
30.27\end{array}$ & $\begin{array}{r}3.85 \\
1.77 \\
10.67\end{array}$ & $\begin{array}{l}0.00 \\
0.00 \\
0.00\end{array}$ & $\begin{array}{l}0.00 \\
0.00 \\
0.00\end{array}$ & $\begin{array}{r}6.21 \\
1.89 \\
20.48\end{array}$ & $\begin{array}{l}0.73 \\
0.95 \\
0.00\end{array}$ & $\begin{array}{l}0.00 \\
0.00 \\
0.00\end{array}$ & $\begin{array}{l}29.02 \\
19.21 \\
61.42\end{array}$ \\
\hline-1.30 & & -0.051 & $\begin{array}{l}\text { Feed } \\
\text { Overs } \\
\text { Unders }\end{array}$ & $\begin{array}{l}0.00 \\
0.00 \\
0.00\end{array}$ & $\begin{array}{l}0.00 \\
0.00 \\
0.00\end{array}$ & $\begin{array}{l}0.00 \\
0.00 \\
0.00\end{array}$ & $\begin{array}{l}0.00 \\
0.00 \\
0.00\end{array}$ & $\begin{array}{l}0.00 \\
0.00 \\
0.00\end{array}$ & $\begin{array}{l}0.00 \\
0.00 \\
0.00\end{array}$ & $\begin{array}{r}11.98 \\
4.58 \\
36.46\end{array}$ & $\begin{array}{r}11.98 \\
4.58 \\
36.46\end{array}$ \\
\hline Total & & - & $\begin{array}{l}\text { Feed } \\
\text { Overs } \\
\text { Unders }\end{array}$ & $\begin{array}{l}76.15 \\
89.41 \\
32.39\end{array}$ & $\begin{array}{r}4.93 \\
3.17 \\
10.67\end{array}$ & $\begin{array}{l}0.00 \\
0.00 \\
0.00\end{array}$ & $\begin{array}{l}0.00 \\
0.00 \\
0.00\end{array}$ & $\begin{array}{r}6.21 \\
1.89 \\
20.48\end{array}$ & $\begin{array}{l}0.73 \\
0.95 \\
0.00\end{array}$ & $\begin{array}{r}11.98 \\
4.58 \\
36.46\end{array}$ & $\begin{array}{l}100.00 \\
100.00 \\
100.00\end{array}$ \\
\hline
\end{tabular}

* $R$ designates round sieve opening. 
TABLE B-20. COMPONENT/SIZE DISTRIBUTION (6 rpm, feedrate $=12.57 \mathrm{Mg} / \mathrm{h}(13.83 \mathrm{tons} / \mathrm{h})$, January 1981) (\% by weight)

\begin{tabular}{|c|c|c|c|c|c|c|c|c|c|c|c|}
\hline & \multicolumn{2}{|c|}{ Size class* } & \multirow[b]{2}{*}{ Material } & \multirow{2}{*}{$\begin{array}{l}\text { Paper \& } \\
\text { plastic }\end{array}$} & \multirow{2}{*}{$\begin{array}{l}\text { Organic } \\
\text { other }\end{array}$} & \multirow[b]{2}{*}{ Nonferrous } & \multirow[b]{2}{*}{ Ferrous } & \multirow[b]{2}{*}{ Glass } & \multirow{2}{*}{$\begin{array}{c}\text { Inorganic } \\
\text { other }\end{array}$} & \multirow{2}{*}{$\begin{array}{c}\text { Fines } \\
(-1.30 \mathrm{~mm})\end{array}$} & \multirow[b]{2}{*}{ Total } \\
\hline & $\mathrm{mm}$ & in. & & & & & & & & & \\
\hline+76.20 & & +3 & $\begin{array}{l}\text { Feed } \\
\text { Overs } \\
\text { Unders }\end{array}$ & $\begin{array}{r}8.38 \\
11.52 \\
0.00\end{array}$ & $\begin{array}{l}0.00 \\
0.00 \\
0.00\end{array}$ & $\begin{array}{l}0.00 \\
0.00 \\
0.00\end{array}$ & $\begin{array}{l}0.00 \\
0.00 \\
0.00\end{array}$ & $\begin{array}{l}0.00 \\
0.00 \\
0.00\end{array}$ & $\begin{array}{l}0.00 \\
0.00 \\
0.00\end{array}$ & $\begin{array}{l}0.00 \\
0.00 \\
0.00\end{array}$ & $\begin{array}{r}8.38 \\
11.52 \\
0.00\end{array}$ \\
\hline-76.20 & +50.80 & $-3+-2$ & $\begin{array}{l}\text { Feed } \\
\text { Overs } \\
\text { Unders }\end{array}$ & $\begin{array}{r}20.59 \\
28.31 \\
0.00\end{array}$ & $\begin{array}{l}0.39 \\
0.54 \\
0.00\end{array}$ & $\begin{array}{l}0.00 \\
0.00 \\
0.00\end{array}$ & $\begin{array}{l}0.00 \\
0.00 \\
0.00\end{array}$ & $\begin{array}{l}0.00 \\
0.00 \\
0.00\end{array}$ & $\begin{array}{l}0.00 \\
0.00 \\
0.00\end{array}$ & $\begin{array}{l}0.00 \\
0.00 \\
0.00\end{array}$ & $\begin{array}{r}20.98 \\
28.85 \\
0.00\end{array}$ \\
\hline-50.80 & +25.40 & $-2+1$ & $\begin{array}{l}\text { Feed } \\
\text { Overs } \\
\text { Unders }\end{array}$ & $\begin{array}{r}13.33 \\
18.35 \\
0.00\end{array}$ & $\begin{array}{l}0.20 \\
0.28 \\
0.00\end{array}$ & $\begin{array}{l}0.00 \\
0.00 \\
0.00\end{array}$ & $\begin{array}{l}0.00 \\
0.00 \\
0.00\end{array}$ & $\begin{array}{l}0.00 \\
0.00 \\
0.00\end{array}$ & $\begin{array}{l}0.00 \\
0.00 \\
0.00\end{array}$ & $\begin{array}{l}0.00 \\
0.00 \\
0.00\end{array}$ & $\begin{array}{r}13.53 \\
18.63 \\
0.00\end{array}$ \\
\hline-25.40 & $+31.75 R$ & $-1+1-1 / 4 R$ & $\begin{array}{l}\text { Feed } \\
\text { Overs } \\
\text { Unders }\end{array}$ & $\begin{array}{l}1.19 \\
1.61 \\
0.07\end{array}$ & $\begin{array}{l}0.29 \\
0.40 \\
0.00\end{array}$ & $\begin{array}{l}0.00 \\
0.00 \\
0.00\end{array}$ & $\begin{array}{l}0.00 \\
0.00 \\
0.00\end{array}$ & $\begin{array}{l}0.00 \\
0.00 \\
0.00\end{array}$ & $\begin{array}{l}0.00 \\
0.00 \\
0.00\end{array}$ & $\begin{array}{l}0.00 \\
0.00 \\
0.00\end{array}$ & $\begin{array}{l}1.48 \\
2.01 \\
0.07\end{array}$ \\
\hline$-31.75 \mathrm{~F}$ & $R+15.88$ & $-1-1 / 4 R+5 / 8$ & $\begin{array}{l}\text { Feed } \\
\text { Overs } \\
\text { Unders }\end{array}$ & $\begin{array}{r}8.84 \\
11.32 \\
2.22\end{array}$ & $\begin{array}{l}0.98 \\
1.29 \\
0.16\end{array}$ & $\begin{array}{l}0.00 \\
0.00 \\
0.00\end{array}$ & $\begin{array}{l}0.00 \\
0.00 \\
0.00\end{array}$ & $\begin{array}{l}0.00 \\
0.00 \\
0.00\end{array}$ & $\begin{array}{l}0.00 \\
0.00 \\
0.00\end{array}$ & $\begin{array}{l}0.00 \\
0.00 \\
0.00\end{array}$ & $\begin{array}{r}9.82 \\
12.61 \\
2.38\end{array}$ \\
\hline-15.88 & +1.30 & $-5 / 8+0.051$ & $\begin{array}{l}\text { Feed } \\
\text { Overs } \\
\text { Unders. }\end{array}$ & $\begin{array}{l}16.59 \\
12.92 \\
26.30\end{array}$ & $\begin{array}{l}4.98 \\
3.43 \\
9.14\end{array}$ & $\begin{array}{l}0.03 \\
0.00 \\
0.11\end{array}$ & $\begin{array}{l}0.00 \\
0.00 \\
0.00\end{array}$ & $\begin{array}{r}4.17 \\
1.28 \\
11.89\end{array}$ & $\begin{array}{l}1.64 \\
0.73 \\
4.07\end{array}$ & $\begin{array}{l}0.00 \\
0.00 \\
0.00\end{array}$ & $\begin{array}{l}27.41 \\
18.36 \\
51.51\end{array}$ \\
\hline-1.30 & & -0.051 & $\begin{array}{l}\text { Feed } \\
\text { Overs } \\
\text { Unders }\end{array}$ & $\begin{array}{l}0.00 \\
0.00 \\
0.00\end{array}$ & $\begin{array}{l}0.00 \\
0.00 \\
0.00\end{array}$ & $\begin{array}{l}0.00 \\
0.00 \\
0.00\end{array}$ & $\begin{array}{l}0.00 \\
0.00 \\
0.00\end{array}$ & $\begin{array}{l}0.00 \\
0.00 \\
0.00\end{array}$ & $\begin{array}{l}0.00 \\
0.00 \\
0.00\end{array}$ & $\begin{array}{r}18.40 \\
8.02 \\
46.04\end{array}$ & $\begin{array}{r}18.40 \\
8.02 \\
46.04\end{array}$ \\
\hline Total & & - & $\begin{array}{l}\text { Feed } \\
\text { Overs } \\
\text { Unders }\end{array}$ & $\begin{array}{l}68.92 \\
84.03 \\
28.59\end{array}$ & $\begin{array}{l}6.84 \\
5.94 \\
9.30\end{array}$ & $\begin{array}{l}0.03 \\
0.00 \\
0.11\end{array}$ & $\begin{array}{l}0.00 \\
0.00 \\
0.00\end{array}$ & $\begin{array}{r}4.17 \\
1.28 \\
11.89\end{array}$ & $\begin{array}{l}1.64 \\
0.73 \\
4.07\end{array}$ & $\begin{array}{r}18.40 \\
8.02 \\
46.04\end{array}$ & $\begin{array}{l}100.00 \\
100.00 \\
100.00\end{array}$ \\
\hline
\end{tabular}

$*$ R designates round sieve opening. 
TABLE B-21. COMPONENT/SIZE DISTRIBUTION (9.rpm, feedrate = 1.97 Mg/h $(2.17$ tons/h), January 1981) $(\%$ by weight)

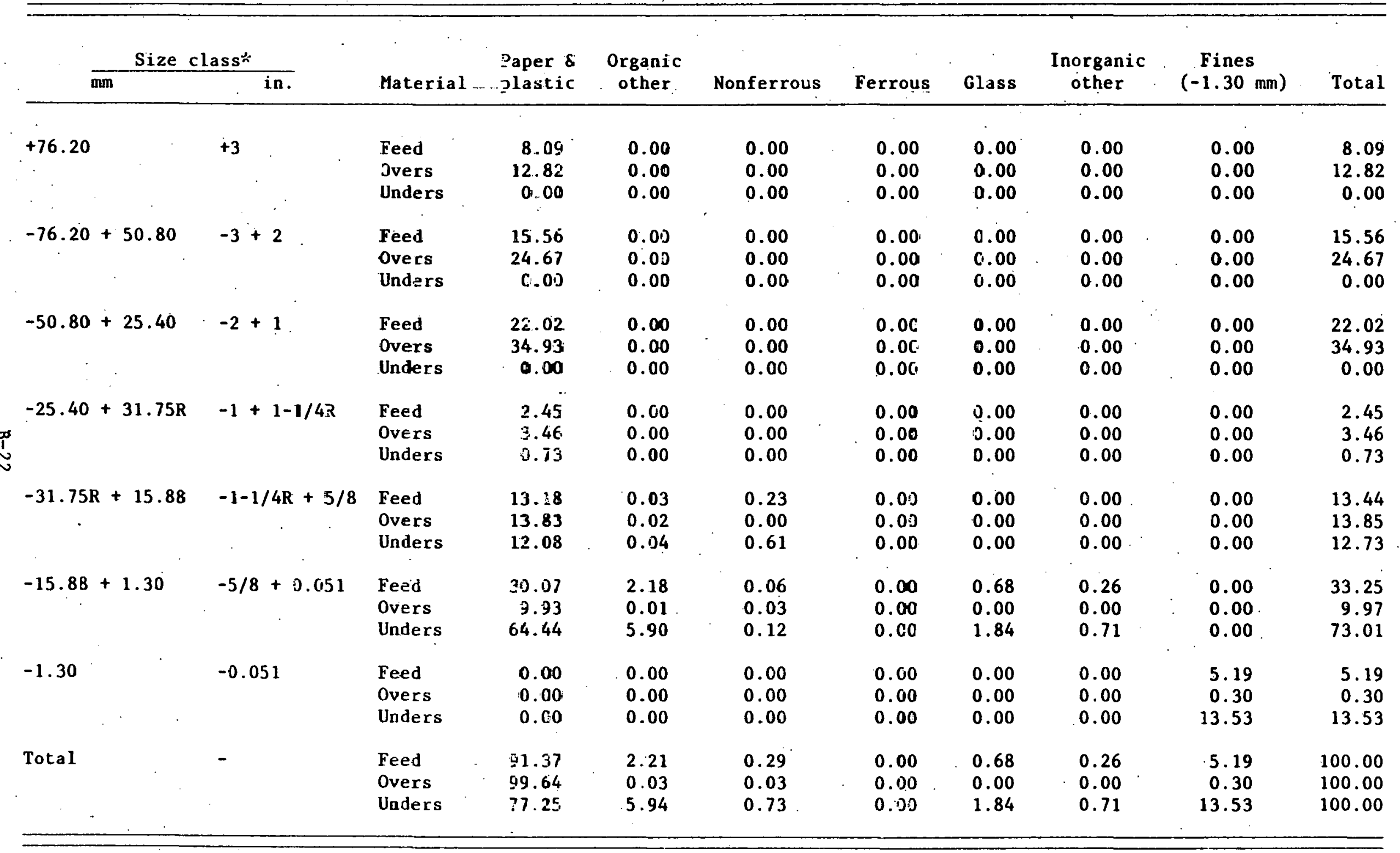

* R designates round sieve opening. 
TABLE B-22. COMPONENT/SIZE DISTRIBUTION $(9 \mathrm{rpm}$, feedrate $=2.55 \mathrm{Mg} / \mathrm{h}(2.80$ tons $/ \mathrm{h})$, January 1981) (\% by we: $g h t$ )

\begin{tabular}{|c|c|c|c|c|c|c|c|c|c|c|c|}
\hline & \multicolumn{2}{|c|}{ Size class* } & \multirow[b]{2}{*}{ Material } & \multirow{2}{*}{$\begin{array}{l}\text { Paper \& } \\
\text { plastic }\end{array}$} & \multirow{2}{*}{$\begin{array}{c}\text { Organic } \\
\text { other }\end{array}$} & \multirow[b]{2}{*}{ Nonferrous } & \multirow[b]{2}{*}{ Ferrous } & \multirow[b]{2}{*}{ Glass } & \multirow{2}{*}{$\begin{array}{c}\text { Inorganic } \\
\text { other }\end{array}$} & \multirow{2}{*}{$\begin{array}{l}\text { Fines } \\
(-1.30 \mathrm{~mm})\end{array}$} & \multirow[b]{2}{*}{ Total } \\
\hline & $\mathrm{mm}$ & in. & & & & & & & & & \\
\hline \multirow[t]{3}{*}{+76.20} & & +3 & Feed & 28.67 & 0.00 & 0.00 & 0.00 & 0.00 & 0.00 & 0.00 & 28.67 \\
\hline & & & Overs & 38.92 & 0.00 & 0.00 & 0.00 & 0.00 & 0.00 & 0.00 & 38.92 \\
\hline & & & Unders & 0.00 & 0.00 & 0.00 & 0.00 & 0.00 & 0.00 & 0.00 & 0.00 \\
\hline \multirow[t]{3}{*}{-76.20} & +50.80 & $-3+2$ & Feed & 18.25 & 0.00 & 0.00 & 0.00 & 0.00 & 0.00 & 0.00 & 18.25 \\
\hline & & & Overs & 24.78 & 0.00 & 0.00 & 0.00 & 0.00 & 0.00 & 0.00 & 24.78 \\
\hline & & & Unders & 0.00 & 0.00 & 0.00 & 0.00 & 0.00 & 0.00 & 0.00 & 0.00 \\
\hline \multirow[t]{3}{*}{-50.80} & +25.40 & $-2+1$ & Feed & 16.40 & 0.17 & 0.58 & 0.00 & 0.00 & 0.00 & 0.00 & 17.15 \\
\hline & & & Overs & 22.27 & 0.23 & 0.79 & 0.00 & 0.00 & 0.00 & 0.00 & 23.29 \\
\hline & & c & Unders & 0.00 & 0.00 & 0.00 & 0.00 & 0.00 & 0.00 & 0.00 & 0.00 \\
\hline \multirow[t]{3}{*}{-25.40} & $+31.75 R$ & $-1+1-1 / 4 R$ & Feed & 0.84 & 0.00 & 0.00 & 0.00 & 0.00 & 0.00 & 0.00 & 0.84 \\
\hline & & & Overs & 1.14 & 0.00 & 0.00 & 0.00 & 0.00 & 0.00 & 0.00 & 1.14 \\
\hline & & & Unders & 0.00 & 0.00 & 0.00 & 0.00 & 0.00 & 0.00 & 0.00 & 0.00 \\
\hline \multirow[t]{3}{*}{$-31.75 f$} & $R+15.88$ & $-1-1 / 4 R+5 / 8$ & Feed & 4.35 & 0.67 & 0.00 & 0.00 & 0.00 & 0.00 & 0.00 & 5.02 \\
\hline & & & Overs & 4.46 & 0.69 & 0.00 & 0.00 & 0.00 & 0.00 & 0.00 & 5.15 \\
\hline & & & Unders & 4.04 & 0.63 & 0.00 & 0.00 & 0.00 & 0.00 & 0.00 & 4.67 \\
\hline \multirow[t]{3}{*}{-15.88} & +1.30 & $-5 / 8+0.051$ & Feed & 9.63 & 4.95 & 0.02 & 0.01 & 5.93 & 0.60 & 0.00 & 21.14 \\
\hline & & & Overs & 3.89 & 1.38 & 0.00 & 0.00 & 0.13 & 0.00 & 0.00 & 5.40 \\
\hline & & & Unders & 25.70 & 14.88 & 0.06 & 0.03 & 22.16 & 2.26 & 0.00 & 65.09 \\
\hline \multirow[t]{3}{*}{-1.30} & & -0.051 & Feed & 0.00 & 0.00 & 0.00 & 0.00 & 0.00 & 0.00 & 8.93 & 8.93 \\
\hline & & & Overs & 0.00 & 0.00 & 0.00 & 0.00 & 0.00 & 0.00 & 1.32 & 1.32 \\
\hline & & & Unders & 0.00 & 0.00 & 0.00 & 0.00 & 0.00 & 0.00 & 30.24 & 30.24 \\
\hline \multirow[t]{3}{*}{ Total } & & - & Feed & 78.14 & 5.79 & 0.60 & 0.01 & 5.93 & 0.60 & 8.93 & 100.00 \\
\hline & & & Overs & 95.46 & 2.30 & 0.79 & 0.00 & 0.13 & 0.00 & 1.32 & 100.00 \\
\hline & & & Unders & 29.74 & 15.51 & 0.06 & 0.03 & 22.16 & 2.26 & 30.24 & 100.00 \\
\hline
\end{tabular}

$\therefore$ R designates round sieve opening. 
TABLE B-23. COMPOHENT/SIZE DISTRIBUTION $(9 \mathrm{rpm}$, feedrate $=7.23 \mathrm{Mg} / \mathrm{h}(7.95$ tons/h), January 1981)

(\% by weight)

\begin{tabular}{|c|c|c|c|c|c|c|c|c|c|c|c|}
\hline & \multicolumn{2}{|c|}{ Size class* } & \multirow{2}{*}{ Material. - } & \multirow{2}{*}{$\begin{array}{l}\text { Paper \& } \\
\text { plastic }\end{array}$} & \multirow{2}{*}{$\begin{array}{c}\text { Organic } \\
\text { other }\end{array}$} & \multirow{2}{*}{ Nonferrous } & \multirow{2}{*}{ Ferrous... } & \multirow[b]{2}{*}{ Glass } & \multirow{2}{*}{$\begin{array}{c}\text { Inorganic } \\
\text { other }\end{array}$} & \multirow{2}{*}{$\begin{array}{l}\text { Fines } \\
(-1.30 \mathrm{~mm})\end{array}$} & \multirow[b]{2}{*}{ Total } \\
\hline & $\mathrm{mm}$ & $\cdots$ & & & & & & & & & \\
\hline+76.20 & & +3 & $\begin{array}{l}\text { Feed } \\
\text { Overs } \\
\text { Unders }\end{array}$ & $\begin{array}{r}12.74 \\
26.09 \\
0.00\end{array}$ & $\begin{array}{l}0.00 \\
0.00 \\
0.00\end{array}$ & $\begin{array}{l}0.00 \\
0.00 \\
0.00\end{array}$ & $\begin{array}{l}0.03 \\
0.05 \\
0.00\end{array}$ & $\begin{array}{l}0.00 \\
0.00 \\
0.00\end{array}$ & $\begin{array}{l}0.00 \\
0.00 \\
0.00\end{array}$ & $\begin{array}{l}0.00 \\
0.00 \\
0.00\end{array}$ & $\begin{array}{r}12.74 \\
26.09 \\
0.00\end{array}$ \\
\hline-76.20 & +50.80 & $-3+2$ & $\begin{array}{l}\text { Feed } \\
\text { Overs } \\
\text { Unders }\end{array}$ & $\begin{array}{r}16.72 \\
34.25 \\
0.00\end{array}$ & $\begin{array}{l}0.13 \\
0.26 \\
0.00\end{array}$ & $\begin{array}{l}0.00 \\
0.00 \\
0.00\end{array}$ & $\begin{array}{l}0.00 \\
0.00 \\
0.00\end{array}$ & $\begin{array}{l}0.00 \\
0.00 \\
0.00\end{array}$ & $\begin{array}{l}0.00 \\
0.00 \\
0.00\end{array}$ & $\begin{array}{l}0.00 \\
0.00 \\
0.00\end{array}$ & $\begin{array}{r}16.85 \\
34.51 \\
0.00\end{array}$ \\
\hline-50.80 & +25.40 & $-2+1$ & $\begin{array}{l}\text { Feed } \\
\text { Overs } \\
\text { Unders }\end{array}$ & $\begin{array}{r}7.25 \\
14.86 \\
0.00\end{array}$ & $\begin{array}{l}0.00 \\
0.00 \\
0.00\end{array}$ & $\begin{array}{l}0.50 \\
1.02 \\
0.00\end{array}$ & $\begin{array}{l}0.00 \\
0.00 \\
0.00\end{array}$ & $\begin{array}{l}0.00 \\
0.00 \\
0.00\end{array}$ & $\begin{array}{l}0.00 \\
0.00 \\
0.00\end{array}$ & $\begin{array}{l}0.00 \\
0.00 \\
0.00\end{array}$ & $\begin{array}{r}7.75 \\
15.88 \\
0.00\end{array}$ \\
\hline-25.40 & $+31.75 \mathrm{~B}$ & $-1+1-1 / 4 R$ & $\begin{array}{l}\text { Feed } \\
\text { Overs } \\
\text { Unders }\end{array}$ & $\begin{array}{l}1.91 \\
3.91 \\
0.00\end{array}$ & $\begin{array}{l}0.00 \\
0.00 \\
0.00\end{array}$ & $\begin{array}{l}0.00 \\
0.00 \\
0.00\end{array}$ & $\begin{array}{l}0.00 \\
0.00 \\
0.00\end{array}$ & $\begin{array}{l}0.00 \\
0.00 \\
0.00\end{array}$ & $\begin{array}{l}0.00 \\
0.00 \\
0.00\end{array}$ & $\begin{array}{l}0.00 \\
0.00 \\
0.00\end{array}$ & $\begin{array}{l}1.91 \\
3.91 \\
0.00\end{array}$ \\
\hline$-31.75 R$ & $R+15.88$ & $-1-1 / 4 A+5 / 8$ & $\begin{array}{l}\text { Feed } \\
\text { Overs } \\
\text { Unders }\end{array}$ & $\begin{array}{l}6.59 \\
9.97 \\
3.37\end{array}$ & $\begin{array}{l}0.05 \\
0.00 \\
0.09\end{array}$ & $\begin{array}{l}0.34 \\
0.69 \\
0.00\end{array}$ & $\begin{array}{l}0 . C 0 \\
0 . C .0 \\
0 . C 0\end{array}$ & $\begin{array}{l}0.00 \\
0.00 \\
0.00\end{array}$ & $\begin{array}{l}0.00 \\
0.00 \\
0.00\end{array}$ & $\begin{array}{l}0.00 \\
0.00 \\
0.00\end{array}$ & $\begin{array}{r}6.98 \\
10.66 \\
3.46\end{array}$ \\
\hline-15.88 & +1.30 & $-5 / 8+0.051$ & $\begin{array}{l}\text { Feed } \\
\text { Overs } \\
\text { Unders }\end{array}$ & $\begin{array}{r}24.73 \\
7.73 \\
40.96\end{array}$ & $\begin{array}{l}4.84 \\
0.27 \\
9.21\end{array}$ & $\begin{array}{l}0.02 \\
0.00 \\
0.04\end{array}$ & $\begin{array}{l}0.03 \\
0.06 \\
0.00\end{array}$ & $\begin{array}{r}6.07 \\
0.03 \\
11.84\end{array}$ & $\begin{array}{l}0.67 \\
0.00 \\
1.31\end{array}$ & $\begin{array}{l}0.00 \\
0.00 \\
0.00\end{array}$ & $\begin{array}{r}36.36 \\
8.09 \\
63.36\end{array}$ \\
\hline-1.30 & " . & -0.051 & $\begin{array}{l}\text { Feed } \\
\text { Overs } \\
\text { Unders }\end{array}$ & $\begin{array}{l}0.00 \\
0.00 \\
0.00\end{array}$ & $\begin{array}{l}0.00 \\
0.00 \\
0.00\end{array}$ & $\begin{array}{l}0.00 \\
0.00 \\
0.00\end{array}$ & $\begin{array}{l}0.00 \\
0.00 \\
0.00\end{array}$ & $\begin{array}{l}0.00 \\
0.00 \\
0.00\end{array}$ & $\begin{array}{l}0.00 \\
0.00 \\
0.00\end{array}$ & $\begin{array}{r}i 7.41 \\
0.86 \\
33.18\end{array}$ & $\begin{array}{r}17.41 \\
0.86 \\
33.18\end{array}$ \\
\hline Total & & - & $\begin{array}{l}\text { Feed } \\
\text { Overs } \\
\text { Unders }\end{array}$ & $\begin{array}{r}69.94 \\
96.81 \\
44.33\end{array}$ & $\begin{array}{l}5.02 \\
0.53 \\
9.30\end{array}$ & $\begin{array}{l}0.86 \\
1.71 \\
0.04\end{array}$ & $\begin{array}{l}0.03 \\
0.06 \\
0.00\end{array}$ & $\begin{array}{r}6.07 \\
0.03 \\
11.84\end{array}$ & $\begin{array}{l}0.67 \\
0.00 \\
1.31\end{array}$ & $\begin{array}{r}17.41 \\
0.86 \\
33.18\end{array}$ & $\begin{array}{l}100.00 \\
100.00 \\
100.00\end{array}$ \\
\hline
\end{tabular}

* $\mathbf{R}$ designates round sieve opeaing. 
TABLE B-24. COMPONENT/SIZ: DISTRIBUTION ( $9 \mathrm{rpm}$, feedrate $=10.49 \mathrm{Mg} / \mathrm{h}$ ( $11.54 \mathrm{tons} / \mathrm{h}$ ), January 1981) (\% by weight)

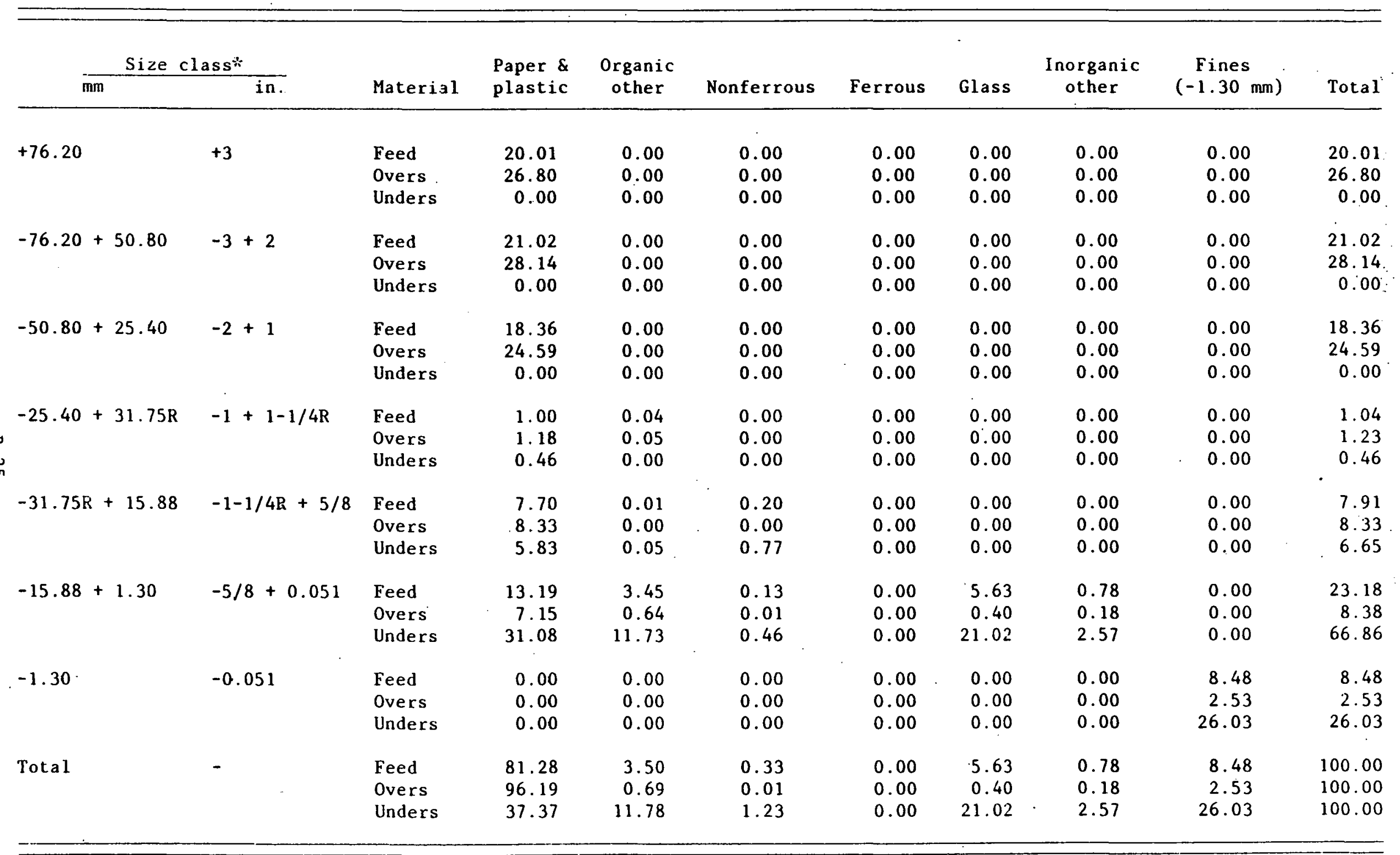

* R designates round sieve opening. 
TABLE B-25. COMPONENT/S ZE DISTRIBUTION (9. rpm, feedrate $17.01 \mathrm{Mg} / \mathrm{h}$ (18.71 tons/h), January 1981) ( $\%$ by weight)

\begin{tabular}{|c|c|c|c|c|c|c|c|c|c|c|c|c|}
\hline & \multicolumn{2}{|c|}{ Size class* } & \multirow[b]{2}{*}{ - } & \multirow{2}{*}{ Haterial } & \multirow{2}{*}{$\begin{array}{l}\text { Paper \& } \\
\text { plastic }\end{array}$} & \multirow{2}{*}{$\begin{array}{c}\text { Organic } \\
\text { other }\end{array}$} & \multirow[b]{2}{*}{ Nonferrous } & \multirow{2}{*}{ Ferrous } & \multirow[b]{2}{*}{ Glass } & \multirow{2}{*}{$\begin{array}{c}\text { Inorganic } \\
\text { other }\end{array}$} & \multirow{2}{*}{$\begin{array}{l}\text { Fines } \\
(-1.30 \mathrm{~mm})\end{array}$} & \multirow[b]{2}{*}{ Total } \\
\hline & $\mathrm{mm}$ & in. & & & & & & & & & & \\
\hline+76.20 & 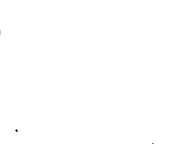 & +3 & & $\begin{array}{l}\text { Feed } \\
\text { Overs } \\
\text { Unders }\end{array}$ & $\begin{array}{r}16.33 \\
25.69 \\
0.00\end{array}$ & $\begin{array}{l}0.00 \\
0.00 \\
0.00\end{array}$ & $\begin{array}{l}0.00 \\
0.00 \\
0.00\end{array}$ & $\begin{array}{l}0.00 \\
0.00 \\
0.00\end{array}$ & $\begin{array}{l}0.00 \\
0.00 \\
0.00\end{array}$ & $\begin{array}{l}0.00 \\
0.00 \\
0.00\end{array}$ & $\begin{array}{l}0.00 \\
0.00 \\
0.00\end{array}$ & $\begin{array}{r}16.33 \\
25.69 \\
0.00\end{array}$ \\
\hline-76.20 & +50.80 & $-3+2$ & . & $\begin{array}{l}\text { Peed } \\
\text { Overs } \\
\text { Dnders }\end{array}$ & $\begin{array}{l}3.97 \\
6.24 \\
0.00 \\
\end{array}$ & $\begin{array}{l}0.00 \\
0.00 \\
0.00\end{array}$ & $\begin{array}{l}0.00 \\
0.00 \\
0.00\end{array}$ & $\begin{array}{l}0.00 \\
0.00 \\
0.00\end{array}$ & $\begin{array}{l}0.00 \\
0.00 \\
0.00\end{array}$ & $\begin{array}{l}0.00 \\
0.00 \\
0.00\end{array}$ & $\begin{array}{l}0.00 \\
0.00 \\
0.00\end{array}$ & $\begin{array}{l}3.97 \\
6.24 \\
0.00\end{array}$ \\
\hline-50.80 & +25.40 & $-2+1$ & & $\begin{array}{l}\text { Teed } \\
\text { Overs } \\
\text { Unders. }\end{array}$ & $\begin{array}{r}15.23 \\
23.97 \\
0.00\end{array}$ & $\begin{array}{l}0.83 \\
1.31 \\
0.00\end{array}$ & $\begin{array}{l}0.00 \\
0.00 \\
0.00\end{array}$ & $\begin{array}{l}0.00 \\
0.00 \\
0.00\end{array}$ & $\begin{array}{l}0.00 \\
0.00 \\
0.00\end{array}$ & $\begin{array}{l}0.00 \\
0.00 \\
0.00\end{array}$ & $\begin{array}{l}0.00 \\
0.00 \\
0.00\end{array}$ & $\begin{array}{r}16.06 \\
25.28 \\
0.00\end{array}$ \\
\hline$-25 \cdot 40$ & $+31.75 R$ & $-1+1-$ & $1: 4 \mathrm{R}$ & $\begin{array}{l}\text { Eeed } \\
\text { Civers } \\
\text { linders }\end{array}$ & $\begin{array}{l}0.77 \\
1.01 \\
0.36\end{array}$ & $\begin{array}{l}0.0 \mathrm{C} \\
0.00 \\
0.36\end{array}$ & $\begin{array}{l}0.00 \\
0.00 \\
0.36\end{array}$ & $\begin{array}{l}0.00 \\
0.00 \\
0.36\end{array}$ & $\begin{array}{l}0.00 \\
0.00 \\
0.36\end{array}$ & $\begin{array}{l}0.00 \\
0.00 \\
0.36\end{array}$ & $\begin{array}{l}0.00 \\
0.00 \\
0.36\end{array}$ & $\begin{array}{l}0.77 \\
1.01 \\
0.36\end{array}$ \\
\hline$-31.75 R$ & $R+15.88$ & $-1-1 / 4 R$ & $+5 ! 8$ & $\begin{array}{l}\text { Eeed } \\
\text { Cvers } \\
\text { lnders }\end{array}$ & $\begin{array}{r}8.55 \\
11.75 \\
2.77\end{array}$ & $\begin{array}{l}0.00 \\
0.00 \\
0.00\end{array}$ & $\begin{array}{l}0.00 \\
0.00 \\
0.00\end{array}$ & $\begin{array}{l}0.00 \\
0.00 \\
0.00\end{array}$ & $\begin{array}{l}0.00 \\
0.00 \\
0.00\end{array}$ & $\begin{array}{l}0.00 \\
0.00 \\
0.00\end{array}$ & $\begin{array}{l}0.00 \\
0.00 \\
0.00\end{array}$ & $\begin{array}{r}8.55 \\
11.75 \\
2.97\end{array}$ \\
\hline-15.88 & +1.30 & $-5 / 8+$ & 0.051 & $\begin{array}{l}\text { Feed } \\
\text { Overs } \\
\text { Unders }\end{array}$ & $\begin{array}{l}34.35 \\
22.93 \\
54.25\end{array}$ & $\begin{array}{l}3.36 \\
0.69 \\
8.01\end{array}$ & $\begin{array}{l}0.11 \\
0.14 \\
0.06\end{array}$ & $\begin{array}{l}0.00 \\
0.00 \\
0.00\end{array}$ & $\begin{array}{l}3.95 \\
0.91 \\
9.27\end{array}$ & $\begin{array}{l}0.61 \\
0.31 \\
1.14\end{array}$ & $\begin{array}{l}0.00 \\
0.00 \\
0.00\end{array}$ & $\begin{array}{l}42.38 \\
24.98 \\
72.73\end{array}$ \\
\hline$-1 \cdot 30$ & & -0.051 & & $\begin{array}{l}\text { Feed } \\
\text { Overs } \\
\text { Unders }\end{array}$ & $\begin{array}{l}0.00 \\
0.00 \\
0.00\end{array}$ & $\begin{array}{l}0.00 \\
0.00 \\
0.00\end{array}$ & $\begin{array}{l}0.00 \\
0.00 \\
0.00\end{array}$ & $\begin{array}{l}0.00 \\
0.00 \\
0.00\end{array}$ & $\begin{array}{l}0.00 \\
0.00 \\
0.00\end{array}$ & $\begin{array}{l}0.00 \\
0.00 \\
0.00\end{array}$ & $\begin{array}{r}11.94 \\
5.05 \\
23.94\end{array}$ & $\begin{array}{r}11.94 \\
5.05 \\
23.94\end{array}$ \\
\hline Total & & - &. & $\begin{array}{l}\text { Feed } \\
\text { Overs } \\
\text { Unders }\end{array}$ & $\begin{array}{l}79.20 \\
91.89 \\
57.58\end{array}$ & $\begin{array}{l}4.19 \\
2.00 \\
8.01\end{array}$ & $\begin{array}{l}0.11 \\
0.14 \\
0.06\end{array}$ & $\begin{array}{l}0.00 \\
0.00 \\
0.00\end{array}$ & $\begin{array}{l}3.95 \\
0.91 \\
9.27\end{array}$ & $\begin{array}{l}0.61 \\
0.31 \\
1.14\end{array}$ & $\begin{array}{r}11.94 \\
5.05 \\
23.94\end{array}$ & $\begin{array}{l}100.00 \\
100.00 \\
100.00\end{array}$ \\
\hline
\end{tabular}

$\because$ R designates round sieve ofening. 
TABLE B-26. COMPONENT/SIZE DISTRIBUTION (12 rpm, feedrate $=3.62 \mathrm{Mg} / \mathrm{h}(3.98 \mathrm{tons} / \mathrm{h})$, January 1981) (\% by weigat)

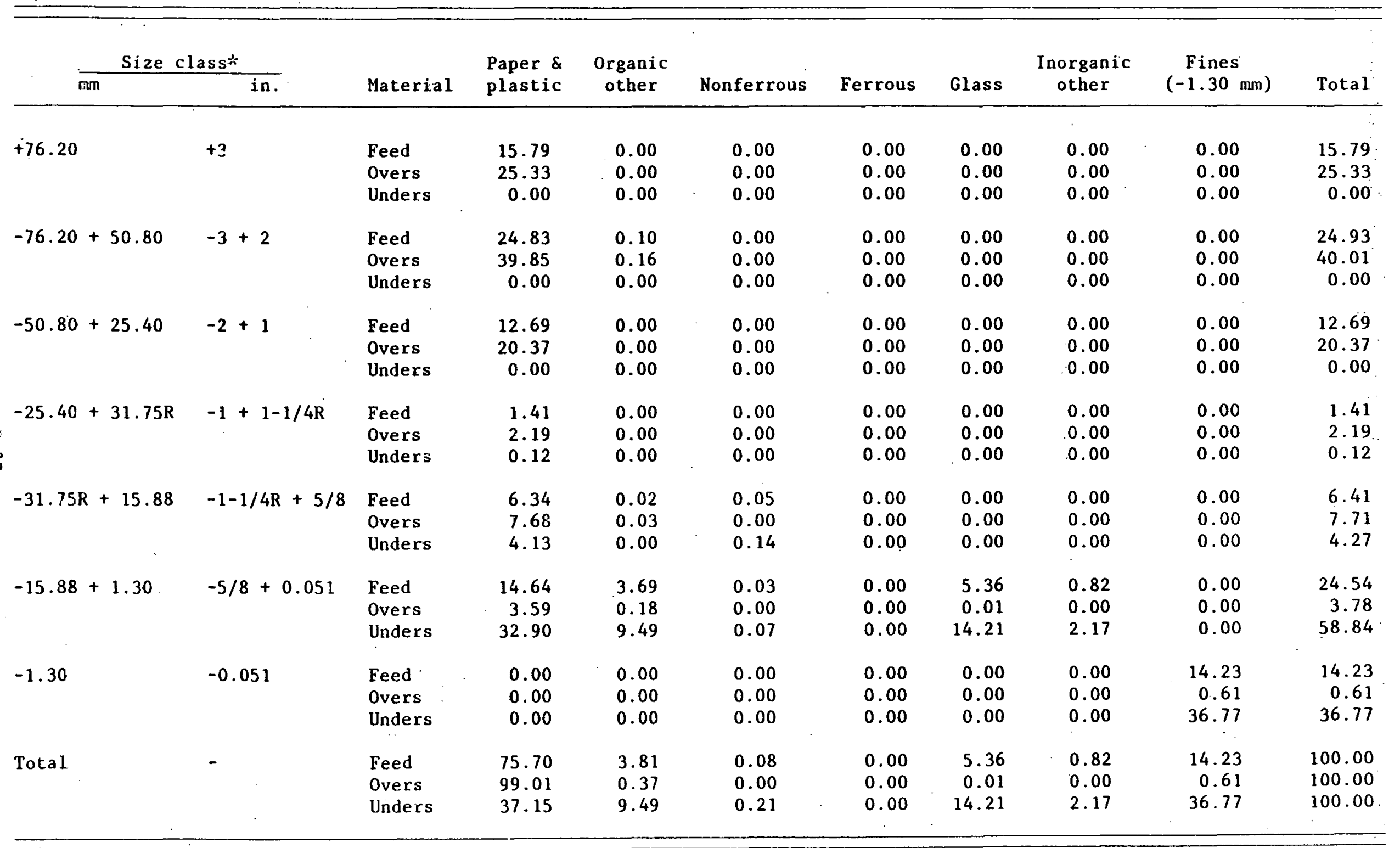

$* \quad \mathrm{R}$ designates round sieve opening. 
TABLE. B-27.. COMPONENT/SIZE DISTREBUTION (12 rpm. feedrate $=6.99 \mathrm{Mg} / \mathrm{h}$ (6.70 tons/h), January 1981$)$ (\% by weight)

\begin{tabular}{|c|c|c|c|c|c|c|c|c|c|c|c|c|}
\hline & \multirow{2}{*}{\multicolumn{2}{|c|}{ Size class* }} & \multirow[b]{2}{*}{ Material } & \multirow{2}{*}{$\begin{array}{l}\text { Paper \& } \\
\text { plastic }\end{array}$} & \multirow{2}{*}{$\begin{array}{l}\text { Organic } \\
\text { other }\end{array}$} & \multirow[b]{2}{*}{ Nonferrous } & \multirow[b]{2}{*}{ Ferrous } & \multirow[b]{2}{*}{ Glass } & \multirow{2}{*}{\multicolumn{2}{|c|}{$\begin{array}{c}\text { Inorganic } \\
\text { other }\end{array}$}} & \multirow{2}{*}{$\begin{array}{l}\text { Fines } \\
(-1.30 \mathrm{~mm})\end{array}$} & \multirow[b]{2}{*}{ Tota 1} \\
\hline$\overline{\mathbf{m}}$ & & & & & & & & & & & & \\
\hline+76.20 & & +3 & $\begin{array}{l}\text { Feed } \\
\text { Overs } \\
\text { Unders }\end{array}$ & $\begin{array}{l}4.47 \\
9.31 \\
0.00\end{array}$ & $\begin{array}{l}0.00 \\
0.00 \\
0.00\end{array}$ & $\begin{array}{l}0.00 \\
0.00 \\
0.00\end{array}$ & $\begin{array}{l}0.00 \\
0.00 \\
0.00\end{array}$ & $\begin{array}{l}0.00 \\
0.00 \\
0.00\end{array}$ & $\begin{array}{l}0.00 \\
0.00 \\
0.00\end{array}$ & & $\begin{array}{l}0.00 \\
0.00 \\
0.00\end{array}$ & $\begin{array}{l}4.47 \\
9.31 \\
0.00\end{array}$ \\
\hline-76.20 & +50.80 & $-3+2$ & $\begin{array}{l}\text { Feed } \\
\text { Overs } \\
\text { Unders }\end{array}$ & $\begin{array}{r}20.97 \\
43.71 \\
0.00\end{array}$ & $\begin{array}{l}0.00 \\
0.00 \\
0.00\end{array}$ & $\begin{array}{l}1.76 \\
3.66 \\
0.00\end{array}$ & $\begin{array}{l}0.00 \\
0.00 \\
0.00\end{array}$ & $\begin{array}{l}0.00 \\
0.00 \\
0.00\end{array}$ & $\begin{array}{l}0.00 \\
0.00 \\
0.00\end{array}$ & $\cdot$ & $\begin{array}{l}0.00 \\
0.00 \\
0.00\end{array}$ & $\begin{array}{r}22.73 \\
47.37 \\
0.00\end{array}$ \\
\hline-50.80 & +25.40 & $-2+1$ & $\begin{array}{l}\text { Feed } \\
\text { Overs } \\
\text { Unders }\end{array}$ & $\begin{array}{r}8.97 \\
18.69 \\
0.00\end{array}$ & $\begin{array}{l}3.07 \\
6.39 \\
0.00\end{array}$ & $\begin{array}{l}0.00 \\
0.00 \\
0.00\end{array}$ & $\begin{array}{l}0.00 \\
0.00 \\
0.00\end{array}$ & $\begin{array}{l}0.00 \\
0.00 \\
0.00\end{array}$ & $\begin{array}{l}0.00 \\
0.00 \\
0.00\end{array}$ & & $\begin{array}{l}0.00 \\
0.00 \\
0.00\end{array}$ & $\begin{array}{r}12.04 \\
25.08 \\
0.00\end{array}$ \\
\hline-25.40 & $+31.75 R$ & $-1+1-1 / 4 R$ & $\begin{array}{l}\text { Feed } \\
\text { Overs } \\
\text { Unders }\end{array}$ & $\begin{array}{l}1.17 \\
1.51 \\
0.85\end{array}$ & $\begin{array}{l}0.03 \\
0.66 \\
0.00\end{array}$ & $\begin{array}{l}0.00 \\
0.00 \\
0.00\end{array}$ & $\begin{array}{l}0.00 \\
0.00 \\
0.00\end{array}$ & $\begin{array}{l}0.00 \\
0.00 \\
0.00\end{array}$ & $\begin{array}{l}0.00 \\
0.00 \\
0.00\end{array}$ & & $\begin{array}{l}0.00 \\
0.00 \\
0.00\end{array}$ & $\begin{array}{l}1.20 \\
1.57 \\
0.85\end{array}$ \\
\hline$-31 \cdot .75 R$ & +15.88 & $-1-1 / 4 R+5 / 8$ & $\begin{array}{l}\text { Feed } \\
\text { Overs } \\
\text { Unders }\end{array}$ & $\begin{array}{l}8.18 \\
7.89 \\
8.45\end{array}$ & $\begin{array}{l}0.41 \\
0.86 \\
0.00\end{array}$ & $\begin{array}{l}0.26 \\
0.00 \\
0.50\end{array}$ & $\begin{array}{l}0.0 \Xi \\
0.06 \\
0.00\end{array}$ & $\begin{array}{l}0.00 \\
0.00 \\
0.00\end{array}$ & $\begin{array}{l}0.12 \\
0.00 \\
0.24\end{array}$ & & $\begin{array}{l}0.00 \\
0.00 \\
0.00\end{array}$ & $\begin{array}{l}9.00 \\
8.81 \\
9.19\end{array}$ \\
\hline-15.88 & +1.30 & $-5 / 8+0.051$ & $\begin{array}{l}\text { Feed } \\
\text { Dvers } \\
\text { Jnders }\end{array}$ & $\begin{array}{r}20.29 \\
4.2 \dot{4} \\
35.1 \overline{1}\end{array}$ & $\begin{array}{r}6.83 \\
2.34 \\
11.06\end{array}$ & $\begin{array}{l}0.18 \\
0.00 \\
0.35\end{array}$ & $\begin{array}{l}0.01 \\
0.00 \\
0.01\end{array}$ & $\begin{array}{l}4.69 \\
0.01 \\
9.01\end{array}$ & $\begin{array}{l}1.52 \\
0.00 \\
2.92\end{array}$ & $\therefore$ & $\begin{array}{l}0.00 \\
0.00 \\
0.00\end{array}$ & $\begin{array}{r}33.57 \\
6.59 \\
58.46\end{array}$ \\
\hline-1.30 & & -0.051 & $\begin{array}{l}\text { Feed } \\
\text { Overs } \\
\text { Unders }\end{array}$ & $\begin{array}{l}0.00 \\
0.00 \\
0.06\end{array}$ & $\begin{array}{l}0.00 \\
0.00 \\
0.00\end{array}$ & $\begin{array}{l}0.00 \\
0.00 \\
0.00\end{array}$ & $\begin{array}{l}0.00 \\
0.00 \\
0.00\end{array}$ & $\begin{array}{l}0.00 \\
0.00 \\
0.00\end{array}$ & $\begin{array}{l}0.00 \\
0.00 \\
0.00\end{array}$ & & $\begin{array}{r}16.99 \\
1.27 \\
31.50\end{array}$ & $\begin{array}{r}16.99 \\
1.27 \\
31.50\end{array}$ \\
\hline Total & & - & $\begin{array}{l}\text { Feed } \\
\text { Gvers } \\
\text { Unders }\end{array}$ & $\begin{array}{l}64.05 \\
85.35 \\
44.41\end{array}$ & $\begin{array}{r}10.39 \\
9.65 \\
11.06\end{array}$ & $\begin{array}{l}2.20 \\
3.66 \\
0.85\end{array}$ & $\begin{array}{l}0.04 \\
0.06 \\
0.01\end{array}$ & $\begin{array}{r}4.69 \\
0.01 \\
9.01\end{array}$ & $\begin{array}{r}1.64 \\
\because 0.00 \\
3.16\end{array}$ & & $\begin{array}{r}16.99 \\
1.27 \\
31.50\end{array}$ & $\begin{array}{l}100.00 \\
100.00 \\
100.00\end{array}$ \\
\hline
\end{tabular}

$* \quad \mathrm{R}$ designates round sieve opening. 
TABLE B-28. COMPONENT/SIZE DISTRIBUTION (12 rpm, feedrate $=6.69 \mathrm{Mg} / \mathrm{h}(7.36 \mathrm{tons} / \mathrm{h})$, January 1981) (\% by weight)

\begin{tabular}{|c|c|c|c|c|c|c|c|c|c|c|c|}
\hline & \multicolumn{2}{|c|}{$\frac{\text { Size class* }}{\text { man }}$} & \multirow[b]{2}{*}{ Material } & \multirow{2}{*}{$\begin{array}{l}\text { Paper \& } \\
\text { plastic }\end{array}$} & \multirow{2}{*}{$\begin{array}{c}\text { Organic } \\
\text { other }\end{array}$} & \multirow[b]{2}{*}{ Nonferrous } & \multirow[b]{2}{*}{ Ferrous } & \multirow[b]{2}{*}{ Glass } & \multirow{2}{*}{$\begin{array}{c}\text { Inorganic } \\
\text { other }\end{array}$} & \multirow{2}{*}{$\begin{array}{l}\text { Fines } \\
(-1.30 \mathrm{~mm})\end{array}$} & \multirow[b]{2}{*}{ Total } \\
\hline & mm & in. & & & & & & & & & \\
\hline+76.20 & & +3 & $\begin{array}{l}\text { Feed } \\
\text { Overs } \\
\text { Unders }\end{array}$ & $\begin{array}{r}9.69 \\
16.74 \\
0.00\end{array}$ & $\begin{array}{l}0.00 \\
0.00 \\
0.00\end{array}$ & $\begin{array}{l}0.00 \\
0.00 \\
0.00\end{array}$ & $\begin{array}{l}0.00 \\
0.00 \\
0.00\end{array}$ & $\begin{array}{l}0.00 \\
0.00 \\
0.00\end{array}$ & $\begin{array}{l}0.00 \\
0.00 \\
0.00\end{array}$ & $\begin{array}{l}0.00 \\
0.00 \\
0.00\end{array}$ & $\begin{array}{r}9.69 \\
16.74 \\
0.00\end{array}$ \\
\hline-76.20 & +50.80 & $-3+2$ & $\begin{array}{l}\text { Feed } \\
\text { Overs } \\
\text { Unders }\end{array}$ & $\begin{array}{r}12.55 \\
21.67 \\
0.00\end{array}$ & $\begin{array}{l}0.05 \\
0.08 \\
0.00\end{array}$ & $\begin{array}{l}0.00 \\
0.00 \\
0.00\end{array}$ & $\begin{array}{l}0.00 \\
0.00 \\
0.00\end{array}$ & $\begin{array}{l}0.00 \\
0.00 \\
0.00\end{array}$ & $\begin{array}{l}0.00 \\
0.00 \\
0.00\end{array}$ & $\begin{array}{l}0.00 \\
0.00 \\
0.00\end{array}$ & $\begin{array}{r}12.60 \\
21.75 \\
0.00\end{array}$ \\
\hline-50.80 & +25.40 & $-2+1$ & $\begin{array}{l}\text { Feed } \\
\text { Overs } \\
\text { Unders }\end{array}$ & $\begin{array}{r}19.21 \\
33.17 \\
0.00\end{array}$ & $\begin{array}{l}0.36 \\
0.63 \\
0.00\end{array}$ & $\begin{array}{l}0.00 \\
0.00 \\
0.00\end{array}$ & $\begin{array}{l}0.00 \\
0.00 \\
0.00\end{array}$ & $\begin{array}{l}0.00 \\
0.00 \\
0.00\end{array}$ & $\begin{array}{l}0.00 \\
0.00 \\
0.00\end{array}$ & $\begin{array}{l}0.00 \\
0.00 \\
0.00\end{array}$ & $\begin{array}{r}19.57 \\
33.80 \\
0.00\end{array}$ \\
\hline-25.40 & $+31.75 R$ & $-1+1-1 / 4 R$ & $\begin{array}{l}\text { Feed } \\
\text { Overs } \\
\text { Unders }\end{array}$ & $\begin{array}{l}1.43 \\
2.01 \\
0.64\end{array}$ & $\begin{array}{l}0.33 \\
0.00 \\
0.79\end{array}$ & $\begin{array}{l}0.00 \\
0.00 \\
0.00\end{array}$ & $\begin{array}{l}0.00 \\
0.00 \\
0.00\end{array}$ & $\begin{array}{l}0.00 \\
0.00 \\
0.00\end{array}$ & $\begin{array}{l}0.00 \\
0.00 \\
0.00\end{array}$ & $\begin{array}{l}0.00 \\
0.00 \\
0.00\end{array}$ & $\begin{array}{l}1.76 \\
2.01 \\
1.43\end{array}$ \\
\hline$-31.75 \mathrm{~F}$ & $R+15.88$ & $-1-1 / 4 R+5 / 8$ & $\begin{array}{l}\text { Feed } \\
\text { Overs } \\
\text { Unders }\end{array}$ & $\begin{array}{r}8.54 \\
11.25 \\
4.82\end{array}$ & $\begin{array}{l}0.38 \\
0.00 \\
0.91\end{array}$ & $\begin{array}{l}0.24 \\
0.00 \\
0.57\end{array}$ & $\begin{array}{l}0.00 \\
0.00 \\
0.00\end{array}$ & $\begin{array}{l}0.00 \\
0.00 \\
0.00\end{array}$ & $\begin{array}{l}0.00 \\
0.00 \\
0.00\end{array}$ & $\begin{array}{l}0.00 \\
0.00 \\
0.00\end{array}$ & $\begin{array}{r}9.16 \\
11.25 \\
6.30\end{array}$ \\
\hline-15.88 & +1.30 & $-5 / 8+0.051$ & $\begin{array}{l}\text { Feed } \\
\text { Overs } \\
\text { Unders }\end{array}$ & $\begin{array}{l}27.06 \\
11.99 \\
47.77\end{array}$ & $\begin{array}{l}4.31 \\
0.34 \\
9.77\end{array}$ & $\begin{array}{l}0.21 \\
0.09 \\
0.38\end{array}$ & $\begin{array}{l}0.00 \\
0.00 \\
0.00\end{array}$ & $\begin{array}{l}3.16 \\
0.11 \\
7.36\end{array}$ & $\begin{array}{l}0.00 \\
0.00 \\
0.00\end{array}$ & $\begin{array}{l}0.00 \\
0.00 \\
0.00\end{array}$ & $\begin{array}{l}34.74 \\
12.53 \\
65.28\end{array}$ \\
\hline-1.30 & & -0.051 & $\begin{array}{l}\text { Feed } \\
\text { Overs } \\
\text { Unders }\end{array}$ & $\begin{array}{l}0.00 \\
0.00 \\
0.00\end{array}$ & $\begin{array}{l}0.00 \\
0.00 \\
0.00\end{array}$ & $\begin{array}{l}0.00 \\
0.00 \\
0.00\end{array}$ & $\begin{array}{l}0.00 \\
0.00 \\
0.00\end{array}$ & $\begin{array}{l}0.00 \\
0.00 \\
0.00\end{array}$ & $\begin{array}{l}0.00 \\
0.00 \\
0.00\end{array}$ & $\begin{array}{r}12.48 \\
1.92 \\
26.99\end{array}$ & $\begin{array}{r}12.48 \\
1.92 \\
26.99\end{array}$ \\
\hline Total & & - & $\begin{array}{l}\text { Feed } \\
\text { Overs } \\
\text { Unders }\end{array}$ & $\begin{array}{l}78.48 \\
96.83 \\
53.23\end{array}$ & $\begin{array}{r}5.43 \\
1.05 \\
11.47\end{array}$ & $\begin{array}{l}0.45 \\
0.09 \\
0.95\end{array}$ & $\begin{array}{l}0.00 \\
0.00 \\
0.00\end{array}$ & $\begin{array}{l}3.16 \\
0.11 \\
7.36\end{array}$ & $\begin{array}{r}0.00 \\
0.00 \\
0.00\end{array}$ & $\begin{array}{r}12.48 \\
1.92 \\
26.99\end{array}$ & $\begin{array}{l}100.00 \\
100.00 \\
100.00\end{array}$ \\
\hline
\end{tabular}

* $\mathrm{R}$ designates round sieve opening. 
TABLE B-29. COMPONENT/SIZE DISTRIBLTION (12 rpm, feedrate $=7.42 \mathrm{Mg} / \mathrm{h}(8.16 \mathrm{tons} / \mathrm{h})$, January 1981)

(\% by weight)

\begin{tabular}{|c|c|c|c|c|c|c|c|c|c|c|c|}
\hline & \multicolumn{2}{|c|}{ Size class* } & \multirow[b]{2}{*}{ Haterial } & \multirow{2}{*}{$\begin{array}{l}\text { Paper \& } \\
\text { plastic }\end{array}$} & \multirow{2}{*}{$\begin{array}{l}\text { Organic } \\
\text { other }\end{array}$} & \multirow[b]{2}{*}{ Nonferrous } & \multirow[b]{2}{*}{ Ferrous } & \multirow[b]{2}{*}{ Glass } & \multirow{2}{*}{$\begin{array}{c}\text { Inorganic } \\
\text { other }\end{array}$} & \multirow{2}{*}{$\begin{array}{l}\text { Fines } \\
(-1.30 \mathrm{~mm})\end{array}$} & \multirow[b]{2}{*}{ Total } \\
\hline & $\mathrm{mm}$ & in. & & & & & & & & & \\
\hline+76.20 & $\therefore$ & +3 & $\begin{array}{l}\text { Feed } \\
\text { Dvers } \\
\text { iJnders }\end{array}$ & $\begin{array}{r}5.66 \\
11.01 \\
0.00\end{array}$ & $\begin{array}{l}0.00 \\
0.00 \\
0.00\end{array}$ & $\begin{array}{l}0.00 \\
0.00 \\
0.00\end{array}$ & $\begin{array}{r}0.00 \\
0.00 \\
0.00\end{array}$ & $\begin{array}{l}0.00 \\
0.00 \\
0.00\end{array}$ & $\begin{array}{l}0.00 \\
0.00 \\
0.00\end{array}$ & $\begin{array}{l}0.00 \\
0.00 \\
0.00\end{array}$ & $\begin{array}{r}5.66 \\
11.01 \\
0.00\end{array}$ \\
\hline-76.20 & +50.80 & $-3+2$ & $\begin{array}{l}\text { Feed } \\
\text { Dvers } \\
\text { Jnders }\end{array}$ & $\begin{array}{r}17.39 \\
33.84 \\
0.00\end{array}$ & $\begin{array}{l}0.00 \\
0.00 \\
0.00\end{array}$ & $\begin{array}{l}0.00 \\
0.00 \\
0.00\end{array}$ & $\begin{array}{l}0.00 \\
0.00 \\
0.00\end{array}$ & $\begin{array}{l}0.00 \\
0.00 \\
0.00\end{array}$ & $\begin{array}{l}0.00 \\
0.00 \\
0.00\end{array}$ & $\begin{array}{l}0.00 \\
0.00 \\
0.00\end{array}$ & $\begin{array}{r}17.39 \\
33.84 \\
0.00\end{array}$ \\
\hline-50.80 & +25.40 & $-2+1$ & $\begin{array}{l}\text { Peed } \\
\text { Dvers } \\
\text { iJnders }\end{array}$ & $\begin{array}{r}14.28 \\
27.78 \\
0.00\end{array}$ & $\begin{array}{l}0.05 \\
0.09 \\
0.00\end{array}$ & $\begin{array}{l}0.00 \\
0.00 \\
0.00\end{array}$ & $\begin{array}{l}0.00 \\
0.00 \\
0.00\end{array}$ & $\begin{array}{l}0.00 \\
0.00 \\
0.00\end{array}$ & $\begin{array}{l}0.00 \\
0.00 \\
0.00\end{array}$ & $\begin{array}{l}0.00 \\
0.00 \\
0.00\end{array}$ & $\begin{array}{r}14.33 \\
27.87 \\
0.00\end{array}$ \\
\hline-25.40 & $+31.75 \mathrm{R}$ & $-1+1-1 / 4 R$ & $\begin{array}{l}\text { Feed } \\
\text { Dvers } \\
\text { Inders }\end{array}$ & $\begin{array}{l}1.4 \pi \\
2.78 \\
0.06\end{array}$ & $\begin{array}{l}0.44 \\
0.00 \\
0.91\end{array}$ & $\begin{array}{l}0.00 \\
0.00 \\
0.00\end{array}$ & $\begin{array}{l}0.00 \\
0.00 \\
0.00\end{array}$ & $\begin{array}{l}0.00 \\
0.00 \\
0.00\end{array}$ & $\begin{array}{l}0.00 \\
0.00 \\
0.00\end{array}$ & $\begin{array}{l}0.00 \\
0.00 \\
0.00\end{array}$ & $\begin{array}{l}1.91 \\
2.78 \\
1.00\end{array}$ \\
\hline$-31.75 f$ & $R+15.88$ & $-1-1 / 4 R+5 / 8$ & $\begin{array}{l}\text { Feed. } \\
\text { Dvers } \\
\text { Inders }\end{array}$ & $\begin{array}{r}7.8 \mathrm{c} \\
12.75 \\
2.76\end{array}$ & $\begin{array}{l}0.03 \\
0.05 \\
0.00\end{array}$ & $\begin{array}{l}0.05 \\
0.10 \\
0.00\end{array}$ & $\begin{array}{l}0.00 \\
0.00 \\
0.00\end{array}$ & $\begin{array}{l}0.00 \\
0.00 \\
0.00\end{array}$ & $\begin{array}{l}0.00 \\
0.00 \\
0.00\end{array}$ & $\begin{array}{l}0.00 \\
0.00 \\
0.00\end{array}$ & $\begin{array}{r}7.97 \\
12.90 \\
2.76\end{array}$ \\
\hline-15.88 & +1.30 & $-5 / 8+0.051$ & $\begin{array}{l}\text { Feed } \\
\text { Dvers } \\
\text { Jnders }\end{array}$ & $\begin{array}{r}23.12 \\
9.29 \\
37.75\end{array}$ & $\begin{array}{l}5.16 \\
0.90 \\
9.66\end{array}$ & $\begin{array}{l}0.01 \\
0.02 \\
0.00\end{array}$ & $\begin{array}{l}0.00 \\
0.00 \\
0.00\end{array}$ & $\begin{array}{r}8.16 \\
0.06 \\
16.72\end{array}$ & $\begin{array}{l}0.00 \\
0.00 \\
0.00\end{array}$ & $\begin{array}{l}0.00 \\
0.00 \\
0.00\end{array}$ & $\begin{array}{l}36.45 \\
10.27 \\
64.13\end{array}$ \\
\hline-1.30 & & -0.051 & $\begin{array}{l}\text { Feed } \\
\text { Dvers } \\
\text { Jnders }\end{array}$ & $\begin{array}{l}0.00 \\
0.00 \\
0.00\end{array}$ & $\begin{array}{l}0.00 \\
0.00 \\
0.00\end{array}$ & $\begin{array}{l}0.00 \\
0.00 \\
0.00\end{array}$ & $\begin{array}{l}0.00 \\
0.00 \\
0.00\end{array}$ & $\begin{array}{l}0.00 \\
0.00 \\
0.00\end{array}$ & $\begin{array}{l}0.00 \\
0.00 \\
0.00\end{array}$ & $\begin{array}{r}16.29 \\
1.33 \\
32.11\end{array}$ & $\begin{array}{r}16.29 \\
1.33 \\
32.11\end{array}$ \\
\hline Total & & - & $\begin{array}{l}\text { Feed } \\
\text { Dvers } \\
\text { Jnders }\end{array}$ & $\begin{array}{l}69.81 \\
97.45 \\
40.60\end{array}$ & $\begin{array}{r}5.68 \\
1.04 \\
10.57\end{array}$ & $\begin{array}{l}0.06 \\
0.12 \\
0.00\end{array}$ & $\begin{array}{l}C .00 \\
C .00 \\
c .00\end{array}$ & $\begin{array}{r}8.16 \\
0.06 \\
16.72\end{array}$ & $\begin{array}{l}0.00 \\
0.00 \\
0.00\end{array}$ & $\begin{array}{r}16.29 \\
1.33 \\
32.11\end{array}$ & $\begin{array}{l}100.00 \\
100.00 \\
100.00\end{array}$ \\
\hline
\end{tabular}

* R designates round sievミ openizg. 
TABLE B-30. COMPONENT/SIZE DISTRIBUTION $\left(12 \mathrm{rpm}_{q ;}\right.$ feedrate $=17.64 \mathrm{Mg} / \mathrm{h}(19.40 \mathrm{tons} / \mathrm{h})$, January 1981$)$ (\% by weight)

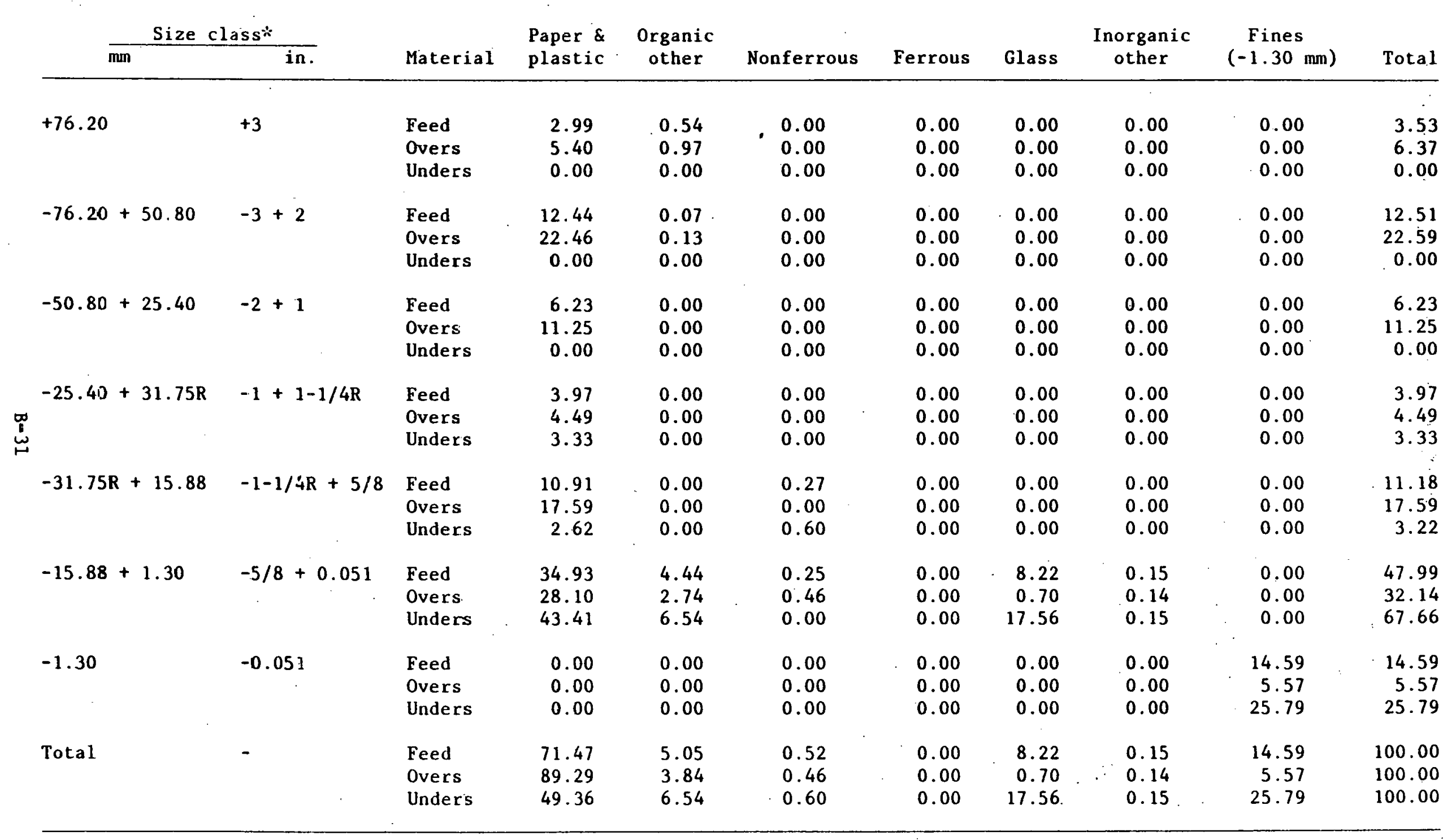

* $\mathrm{R}$ designates round sieve opening. 
TABIE B-31. COMIPONEN:/S1ZE [.ISTRIAUTION i6 $\mathrm{rpm}$, feedrate $=2.82 \mathrm{Hg} / \mathrm{h}(3.10$ Lolls/h), May j98i) ( $q$ by weight)

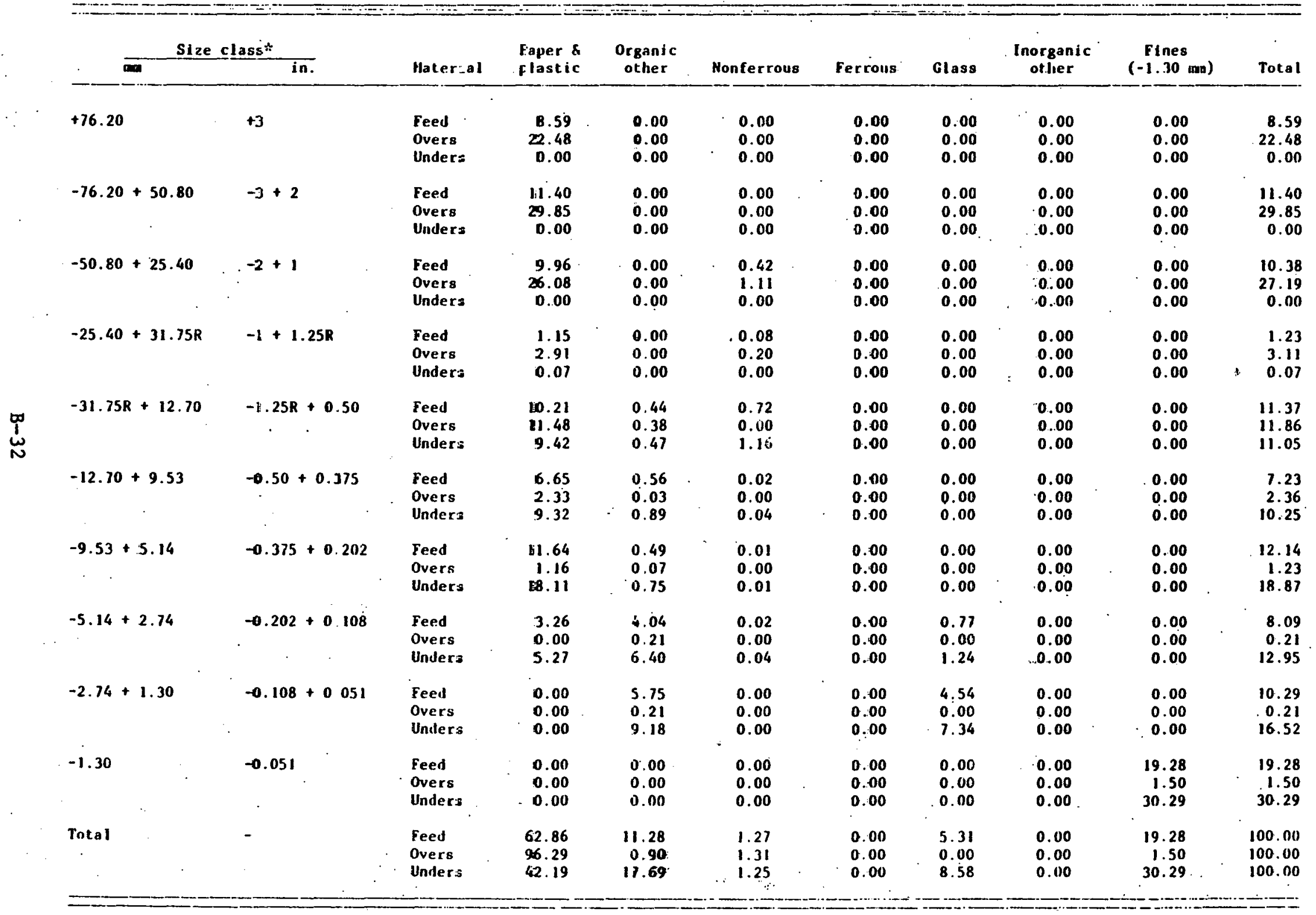

* $R$ desiguates round sieve opening. 


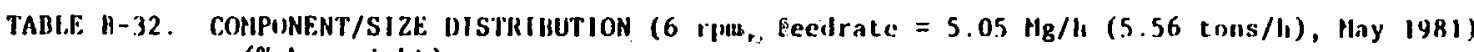
(\% by weight)

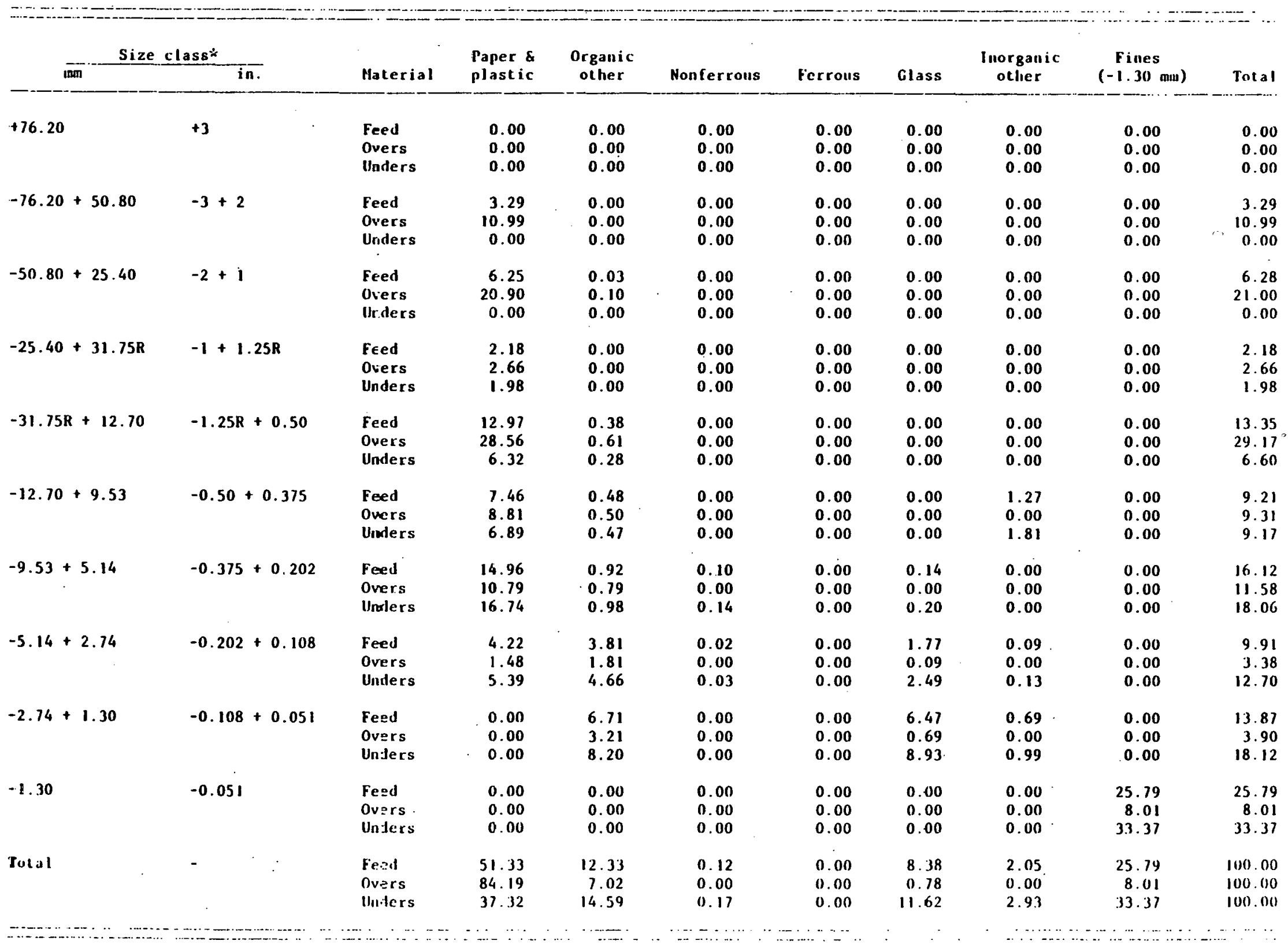

$\therefore$ R designates round sieve opening. 
TABLE B-33. COAPONENT/SI2E DISTRIBUTiON (6 rpm, feedrate $=5.21 \mathrm{Hg} / \mathrm{h}(5.73 \mathrm{tons} / \mathrm{h})$, May 1981)

( $\%$ hy weight)

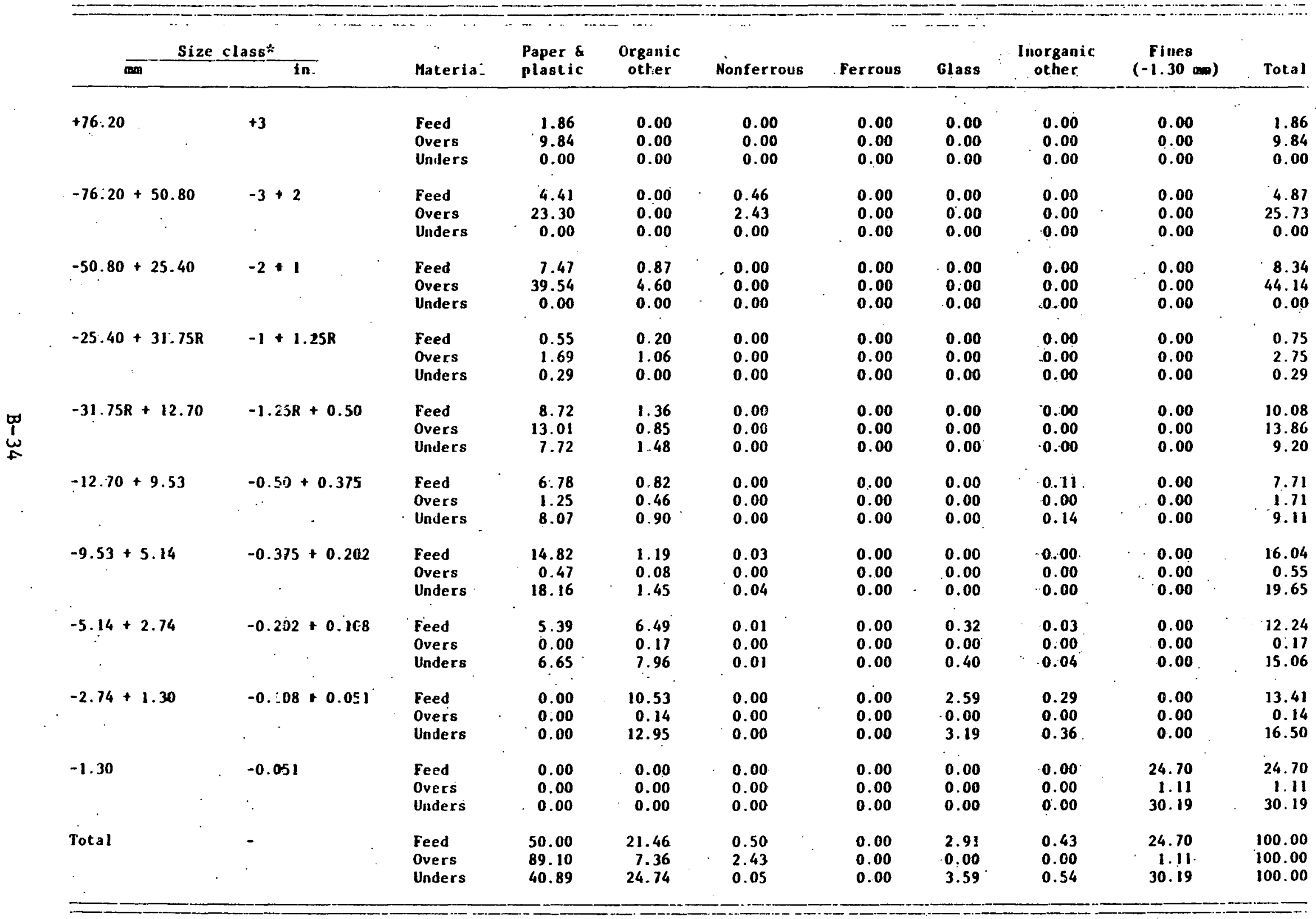

* R designates round sieve opening. 
TABLE B-34. COIPONENT/SIZE DISTRIBUTION $(6 \mathrm{rpm}$, Feedrate $=26.44 \mathrm{Hg} / \mathrm{h}(29.08 \mathrm{tons} / \mathrm{h}), \mathrm{May} 198 \mathrm{I})$ (\% by weight)

\begin{tabular}{|c|c|c|c|c|c|c|c|c|c|c|c|}
\hline \multicolumn{3}{|c|}{ Size class* } & \multirow[b]{2}{*}{ Macerial } & \multirow{2}{*}{$\begin{array}{l}\text { Paper \& } \\
\text { plastic }\end{array}$} & \multirow{2}{*}{$\begin{array}{c}\text { Organic } \\
\text { other }\end{array}$} & \multirow[b]{2}{*}{ Nonferrous } & \multirow[b]{2}{*}{ Ferrolls } & \multirow[b]{2}{*}{ Glass } & \multirow{2}{*}{$\begin{array}{l}\text { Inorganir } \\
\text { other }\end{array}$} & \multirow{2}{*}{$\begin{array}{c}\text { Fines } \\
(-1.30 \text { man })\end{array}$} & \multirow{2}{*}{ Total } \\
\hline & $\overline{\max }$ & in. & & & & & & & & & \\
\hline+76.20 & & +3 & $\begin{array}{l}\text { Feed } \\
\text { Overs } \\
\text { Unders }\end{array}$ & $\begin{array}{l}0.00 \\
0.00 \\
0.00\end{array}$ & $\begin{array}{l}0.00 \\
0.00 \\
0.00\end{array}$ & $\begin{array}{l}0.00 \\
0.00 \\
0.00\end{array}$ & $\begin{array}{l}0.00 \\
0.00 \\
0.00\end{array}$ & $\begin{array}{l}0.00 \\
0.00 \\
0.00\end{array}$ & $\begin{array}{l}0.00 \\
0.00 \\
0.00\end{array}$ & $\begin{array}{l}0.00 \\
0.00 \\
0.00\end{array}$ & $\begin{array}{l}0.00 \\
0.00 \\
0.00\end{array}$ \\
\hline-76.20 & +50.80 & $-3+2$ & $\begin{array}{l}\text { Feed } \\
\text { Overs } \\
\text { Unders }\end{array}$ & $\begin{array}{l}2.37 \\
2.99 \\
0.00\end{array}$ & $\begin{array}{l}0.00 \\
0.00 \\
0.00\end{array}$ & $\begin{array}{l}0.00 \\
0.00 \\
0.00\end{array}$ & $\begin{array}{l}0.00 \\
0.00 \\
0.00\end{array}$ & $\begin{array}{l}0.00 \\
0.00 \\
0.00\end{array}$ & $\begin{array}{l}0.00 \\
0.00 \\
0.00\end{array}$ & $\begin{array}{l}0.00 \\
0.00 \\
0.00\end{array}$ & $\begin{array}{l}2.37 \\
2.99 \\
0.00\end{array}$ \\
\hline-50.80 & +25.40 & $-2+1$ & $\begin{array}{l}\text { Feed } \\
\text { Overs } \\
\text { Unders }\end{array}$ & $\begin{array}{l}6.25 \\
7.88 \\
0.00\end{array}$ & $\begin{array}{l}1.20 \\
1.51 \\
0.00\end{array}$ & $\begin{array}{l}0.00 \\
0.00 \\
0.00\end{array}$ & $\begin{array}{r}0.00 \\
0.00 \\
0.00\end{array}$ & $\begin{array}{l}0.00 \\
0.00 \\
0.00\end{array}$ & $\begin{array}{l}0.00 \\
0.00 \\
0.00\end{array}$ & $\begin{array}{l}0.00 \\
0.00 \\
0.00\end{array}$ & $\begin{array}{l}7.45 \\
9.39 \\
0.00\end{array}$ \\
\hline-25.40 & $+31.75 R$ & $-1+1.25 R$ & $\begin{array}{l}\text { Feed } \\
\text { Overs } \\
\text { Unders }\end{array}$ & $\begin{array}{l}0.96 \\
1.21 \\
0.00\end{array}$ & $\begin{array}{l}0.10 \\
0.12 \\
0.00\end{array}$ & $\begin{array}{l}0.00 \\
0.00 \\
0.00\end{array}$ & $\begin{array}{l}0.00 \\
0.00 \\
0.00\end{array}$ & $\begin{array}{l}0.00 \\
0.00 \\
0.00\end{array}$ & $\begin{array}{l}0.00 \\
0.00 \\
0.00\end{array}$ & $\begin{array}{l}0.00 \\
0.00 \\
0.00\end{array}$ & $\begin{array}{l}1.06 \\
1.33 \\
0.00\end{array}$ \\
\hline-31.75 & $R+12.70$ & $-1.25 R+0.50$ & $\begin{array}{l}\text { Feed } \\
\text { Overs } \\
\text { Unders }\end{array}$ & $\begin{array}{r}10.78 \\
12.50 \\
4.17\end{array}$ & $\begin{array}{l}2.36 \\
2.97 \\
0.00\end{array}$ & $\begin{array}{l}0.00 \\
0.00 \\
0.00\end{array}$ & $\begin{array}{l}0.00 \\
0.00 \\
0.00\end{array}$ & $\begin{array}{l}0.00 \\
0.00 \\
0.00\end{array}$ & $\begin{array}{l}0.00 \\
0.00 \\
0.00\end{array}$ & $\begin{array}{l}0.00 \\
0.00 \\
0.00\end{array}$ & $\begin{array}{r}13.14 \\
15.47 \\
4.17\end{array}$ \\
\hline-12.70 & +9.53 & $-0.50+0.375$ & $\begin{array}{l}\text { Feed } \\
\text { Overs } \\
\text { Unders }\end{array}$ & $\begin{array}{l}5.46 \\
5.47 \\
5.42\end{array}$ & $\begin{array}{l}0.84 \\
0.93 \\
0.51\end{array}$ & $\begin{array}{l}0.00 \\
0.00 \\
0.00\end{array}$ & $\begin{array}{l}0.00 \\
0.00 \\
0.00\end{array}$ & $\begin{array}{l}0.00 \\
0.00 \\
0.00\end{array}$ & $\begin{array}{l}0.00 \\
0.00 \\
0.00\end{array}$ & $\begin{array}{l}0.00 \\
0.00 \\
0.00\end{array}$ & $\begin{array}{l}6.30 \\
6.40 \\
5.93\end{array}$ \\
\hline-9.53 & +5.14 & $-0.375+0.202$ & $\begin{array}{l}\text { Feed } \\
\text { Overs } \\
\text { Unders }\end{array}$ & $\begin{array}{r}9.12 \\
8.55 \\
11.30\end{array}$ & $\begin{array}{l}1.12 \\
1.03 \\
1.47\end{array}$ & $\begin{array}{l}0.04 \\
0.03 \\
0.10\end{array}$ & $\begin{array}{l}0.00 \\
0.00 \\
0.00\end{array}$ & $\begin{array}{l}0.28 \\
0.25 \\
0.41\end{array}$ & $\begin{array}{l}0.07 \\
0.08 \\
0.03\end{array}$ & $\begin{array}{l}0.00 \\
0.00 \\
0.00\end{array}$ & $\begin{array}{r}10.63 \\
9.94 \\
13.31\end{array}$ \\
\hline-5.14 & +2.74 & $-0.202+0.108$ & $\begin{array}{l}\text { Feed } \\
\text { Overs } \\
\text { Unders }\end{array}$ & $\begin{array}{l}1.59 \\
1.33 \\
2.58\end{array}$ & $\begin{array}{l}4.49 \\
4.12 \\
5.91\end{array}$ & $\begin{array}{l}0.00 \\
0.00 \\
0.02\end{array}$ & $\begin{array}{l}0.00 \\
0.00 \\
0.00\end{array}$ & $\begin{array}{l}2.33 \\
1.96 \\
3.76\end{array}$ & $\begin{array}{l}0.17 \\
0.22 \\
0.00\end{array}$ & $\begin{array}{l}0.00 \\
0.00 \\
0.00\end{array}$ & $\begin{array}{r}8.58 \\
7.63 \\
12.27\end{array}$ \\
\hline-2.74 & +1.30 & $-0.108+0.051$ & $\begin{array}{l}\text { Feet } \\
\text { Overs } \\
\text { Und ars }\end{array}$ & $\begin{array}{l}0.00 \\
0.00 \\
0.00\end{array}$ & $\begin{array}{r}7.63 \\
6.77 \\
10.94\end{array}$ & $\begin{array}{l}0.00 \\
0.00 \\
0.00\end{array}$ & $\begin{array}{l}0.00 \\
0.00 \\
0.00\end{array}$ & $\begin{array}{l}7.11 \\
6.85 \\
8.14\end{array}$ & $\begin{array}{l}0.39 \\
0.38 \\
0.42\end{array}$ & $\begin{array}{l}0.00 \\
0.00 \\
0.00\end{array}$ & $\begin{array}{l}15.13 \\
14.00 \\
19.50\end{array}$ \\
\hline-1.30 & & -0.051 & $\begin{array}{l}\text { Fee.1 } \\
\text { Overs } \\
\text { Unders }\end{array}$ & $\begin{array}{l}0.00 \\
0.00 \\
0.00\end{array}$ & $\begin{array}{l}0.00 \\
0.00 \\
0.00\end{array}$ & $\begin{array}{l}0.00 \\
0.00 \\
0.00\end{array}$ & $\begin{array}{l}0.00 \\
0.00 \\
0.00\end{array}$ & $\begin{array}{l}0.00 \\
0.00 \\
0.00\end{array}$ & $\begin{array}{l}0.00 \\
0.00 \\
0.00\end{array}$ & $\begin{array}{l}35.34 \\
32.85 \\
44.82\end{array}$ & $\begin{array}{l}35.34 \\
32.85 \\
44.82\end{array}$ \\
\hline Total & & - & $\begin{array}{l}\text { Feed } \\
\text { Ove -s } \\
\text { Unders }\end{array}$ & $\begin{array}{l}36.53 \\
39.93 \\
23.47\end{array}$ & $\begin{array}{l}17.74 \\
17.45 \\
18.83\end{array}$ & $\begin{array}{l}0.04 \\
0.03 \\
0.12\end{array}$ & $\begin{array}{l}0.00 \\
0.00 \\
0.00\end{array}$ & $\begin{array}{r}9.72 \\
9.06 \\
12.31\end{array}$ & $\begin{array}{l}0.63 \\
0.68 \\
0.45\end{array}$ & $\begin{array}{l}35.34 \\
32.85 \\
44.82\end{array}$ & $\begin{array}{l}100.00 \\
100.00 \\
100.00\end{array}$ \\
\hline
\end{tabular}

* R designates round sieve opening 
TABLE B-35. COHPONENT/SIZE. DISTRJBUTION (6 rpm, feedrate $=29.56 \mathrm{Mg} / \mathrm{h}(32.52$ töns/h), Hay 1981) ( $X$ by weight)

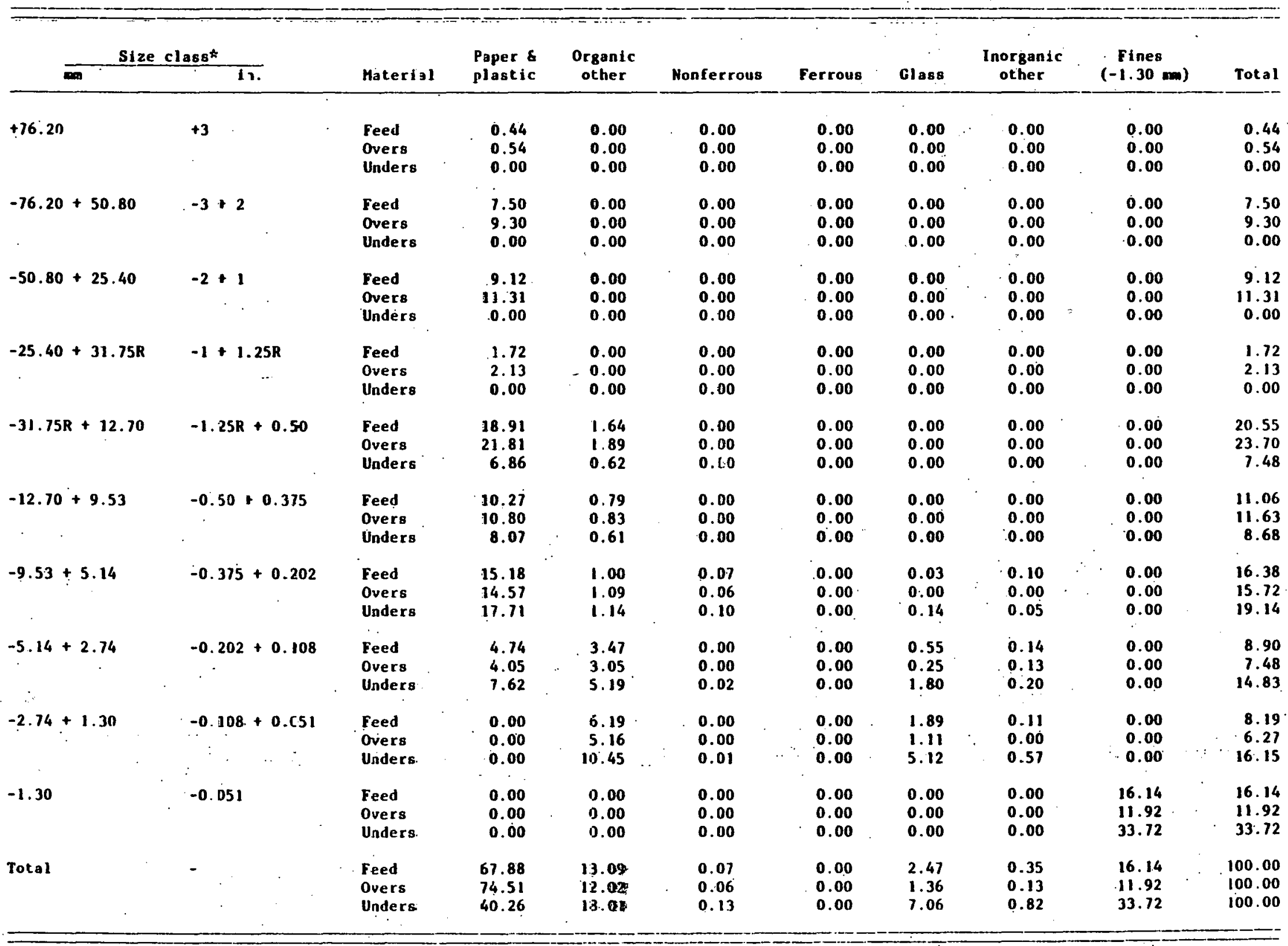

* R designates round sieve opering - 
TABLE B-36. COMPONENT/SIZE DISTRIBUTION $(9 \mathrm{rpm}$, feedrate $=6.32 \mathrm{Mg} / \mathrm{h}(6.97 \mathrm{tolis} / \mathrm{h})$, May 1981) ( $\mathcal{b}$ by weight)

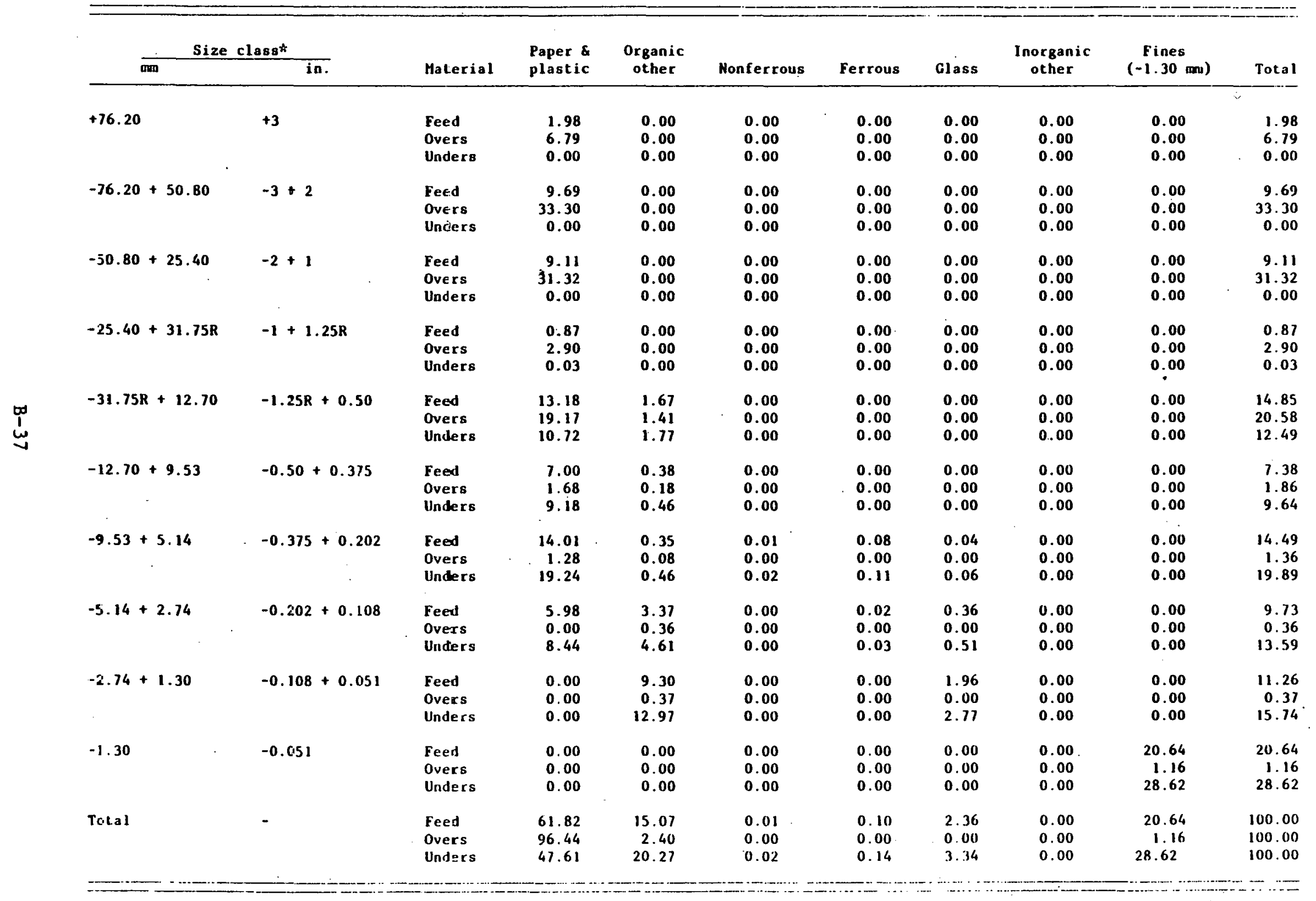

- R designates round sieve opening. 
TABLE B-3i. COHPONENT/SIZE DISTRIBUTION ( 9 rpm, feedrate $=6.48 \mathrm{Mg} / \mathrm{h}(7.13$ tons/h), Hay 1981) ( $Z$ by weilglit)

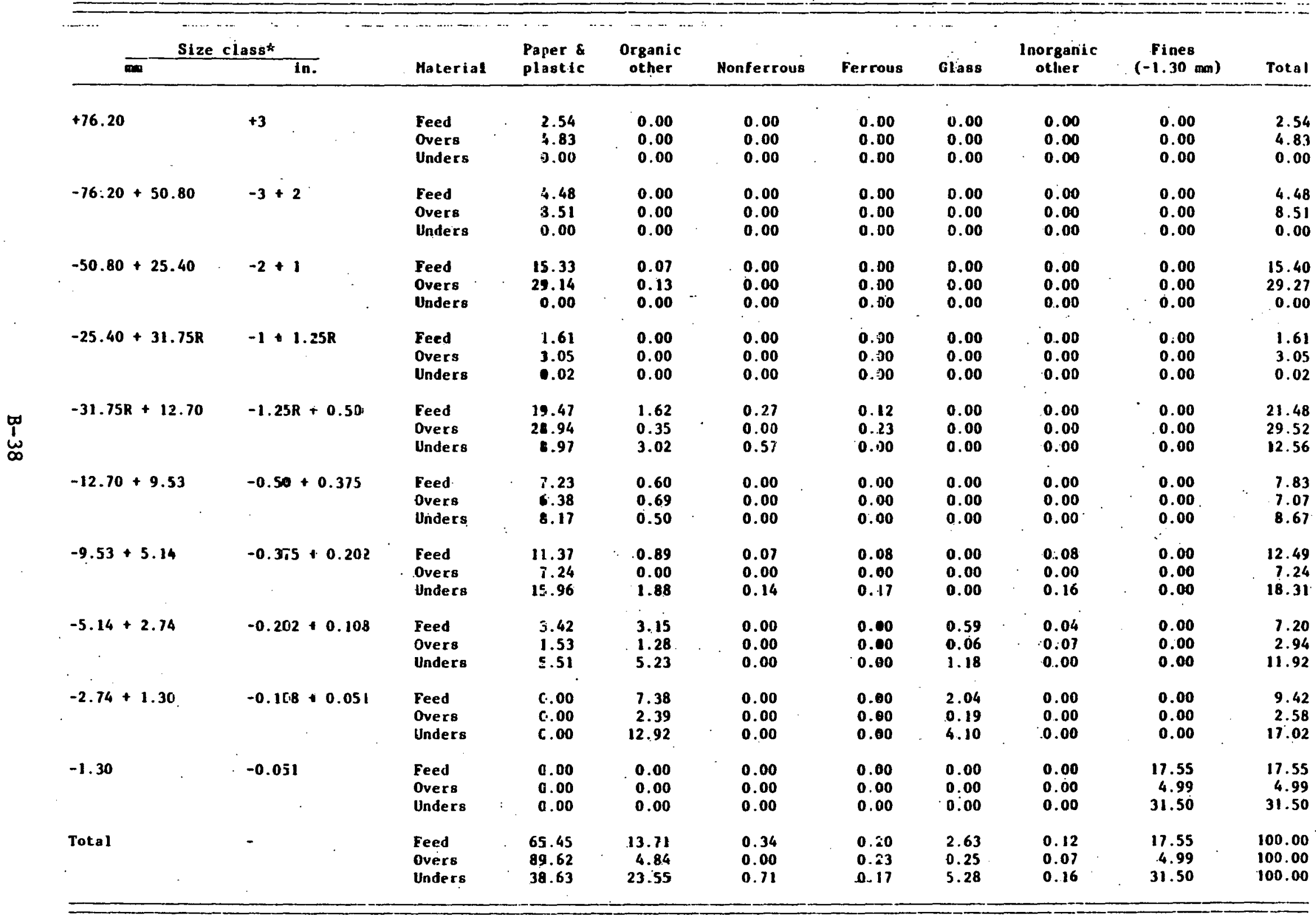

* R desiguales round sleve openiug: 
TABIE B-38. COMPONENT/SIZE DISTRIBUTION $(9 \mathrm{rpm}$, feedrate $=8.56 \mathrm{Mg} / \mathrm{hl}(9.42 \mathrm{tolls} / \mathrm{h})$, Hay 1981) (\% by we ight)

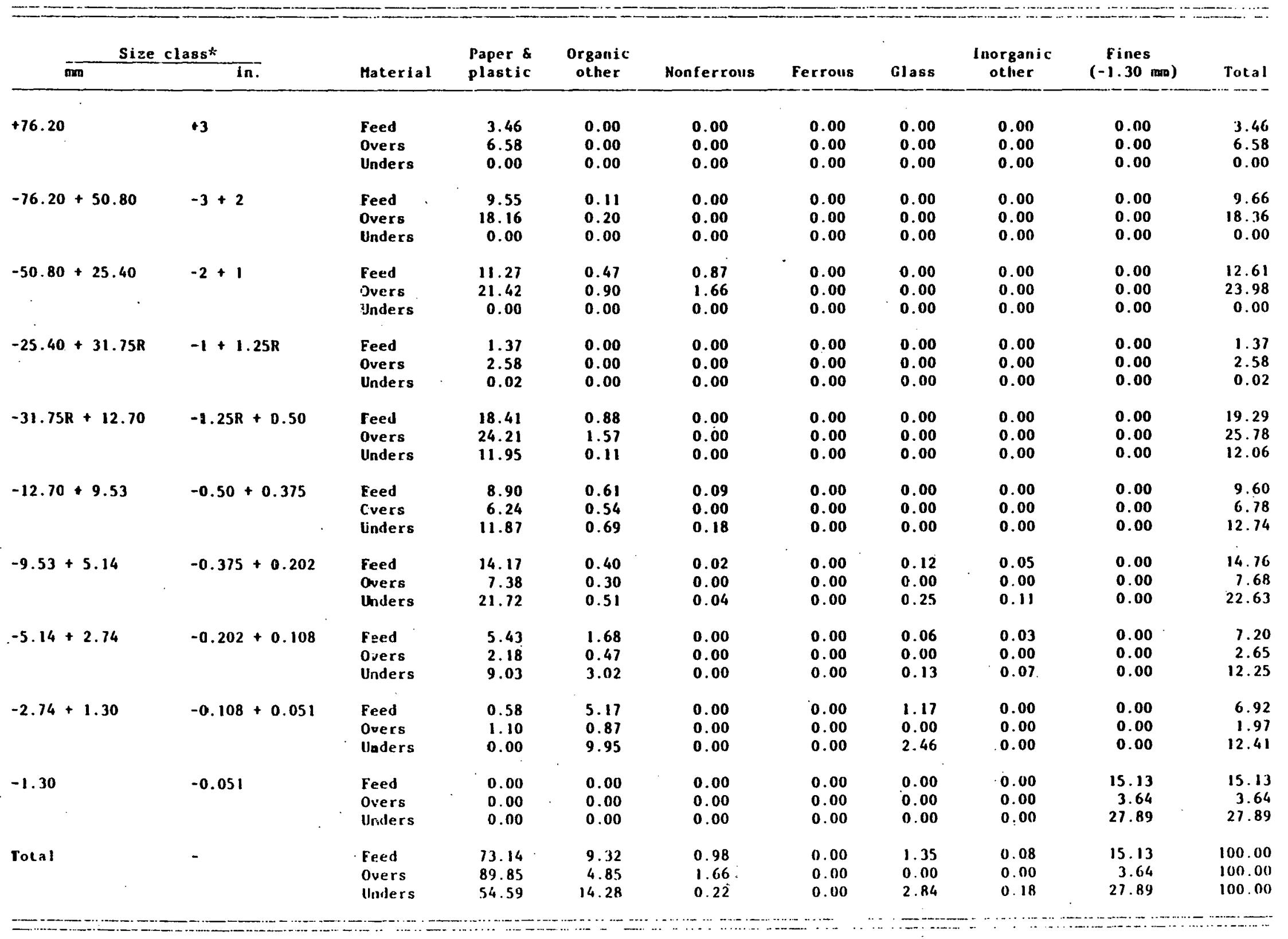

* R designales round sieve opening 
IABLE B-39. COAPONENT;SIZE DISTRIBUTION (9 $\mathrm{rpm}$, feedrate $=31.67 \mathrm{Hg} / \mathrm{h}(34.84 \mathrm{tons} / \mathrm{h})$, Hay i981) (X by weigh:)

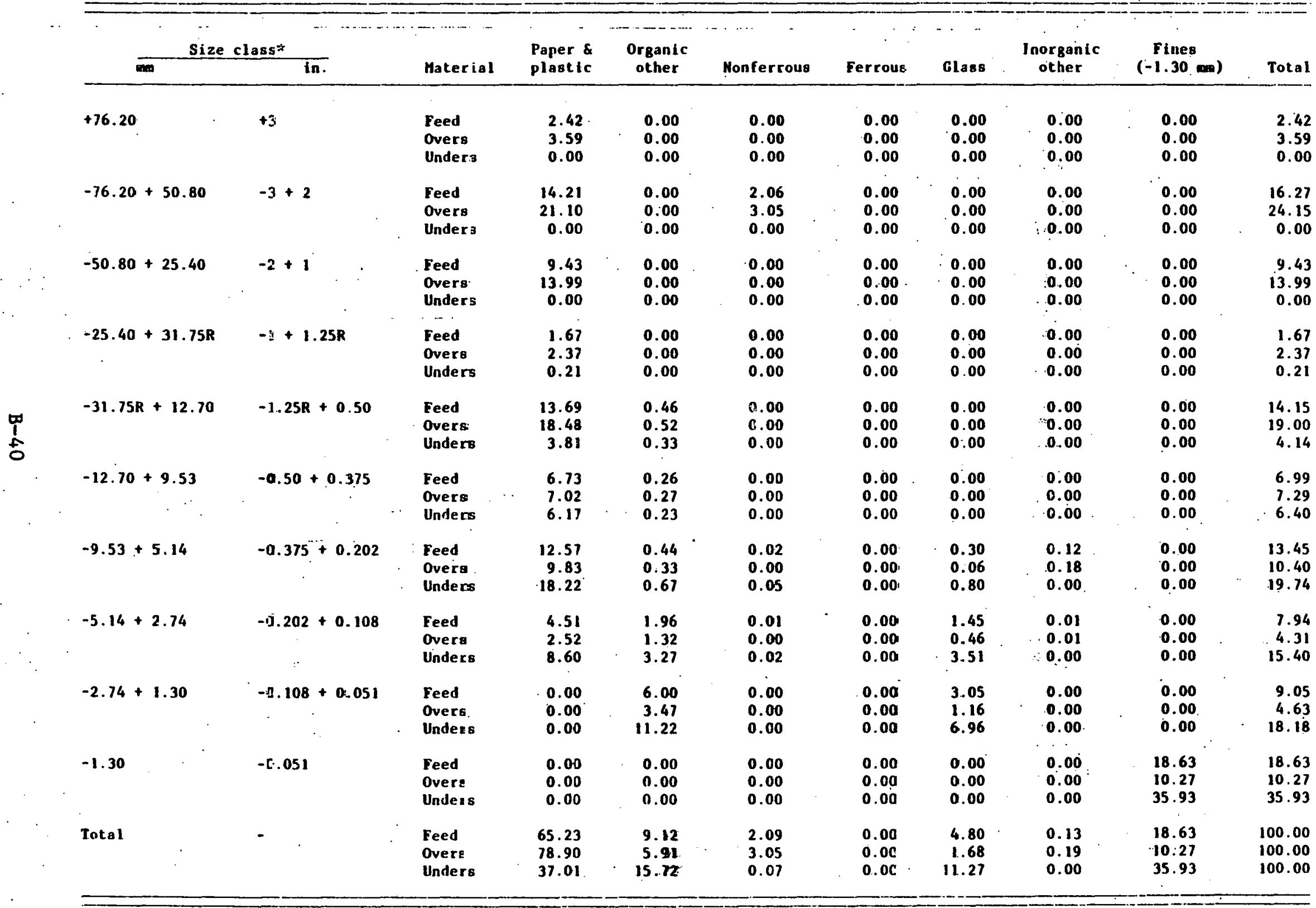

* R designates round sicue opening. 
TABLE B-40. COMPONENT/SIZE DISTRIBUTION $(9 \mathrm{rpm}$, feedrale $=32.90 \mathrm{Hg} / \mathrm{h}(36.19 \mathrm{tolls} / \mathrm{h})$, May 1981) ( $\%$ by weight)

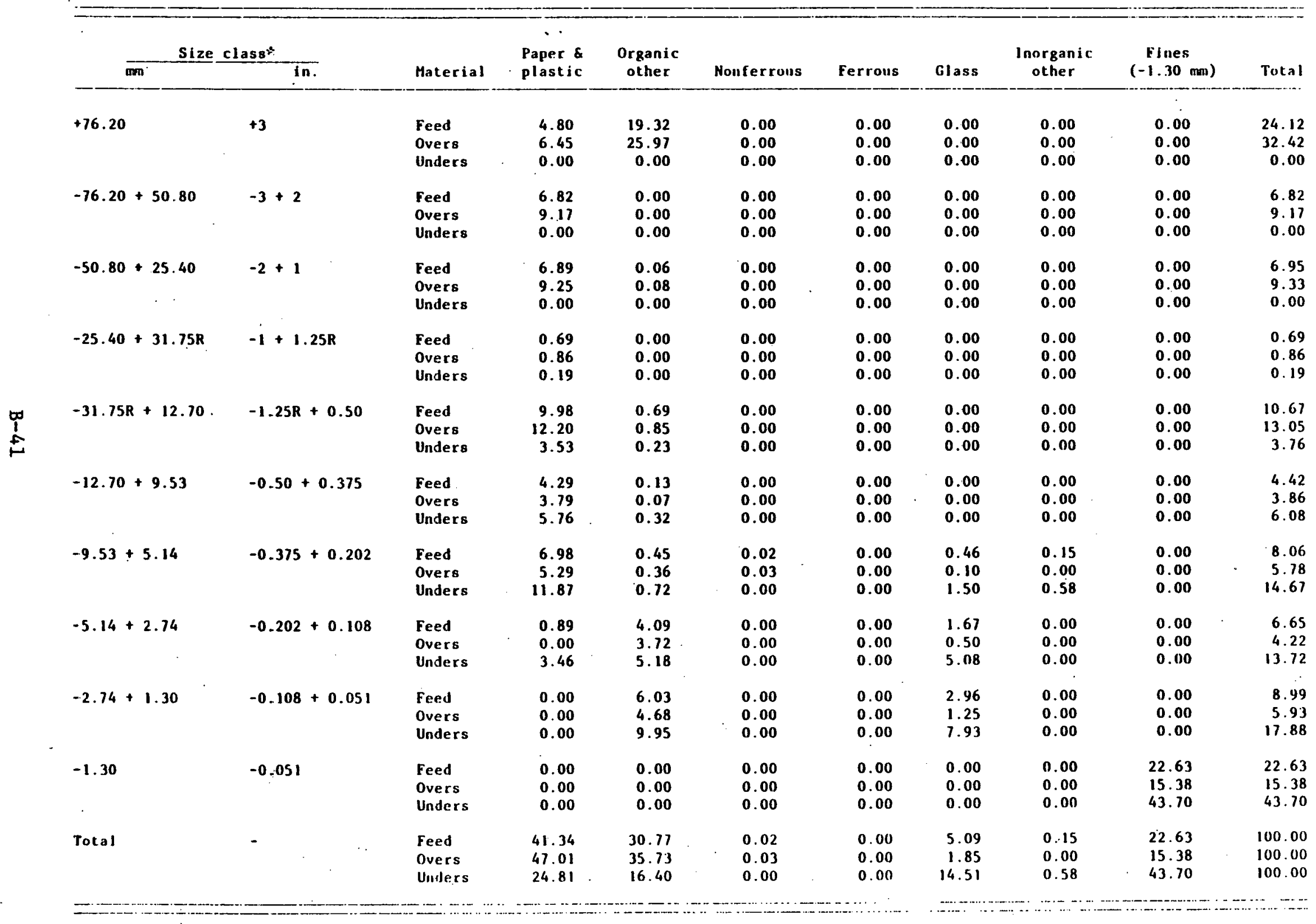

$\because \mathrm{R}$ designates round sieve opening. 
TABLE -41. COHPONENT/SIZE DISTRIBU:IOH (12 rpw, feedrate $=2.92 \mathrm{Mg} / \mathrm{h}(3.21 \mathrm{tons} / \mathrm{h})$, May 1981) ( $\mathcal{H}$ by weight)

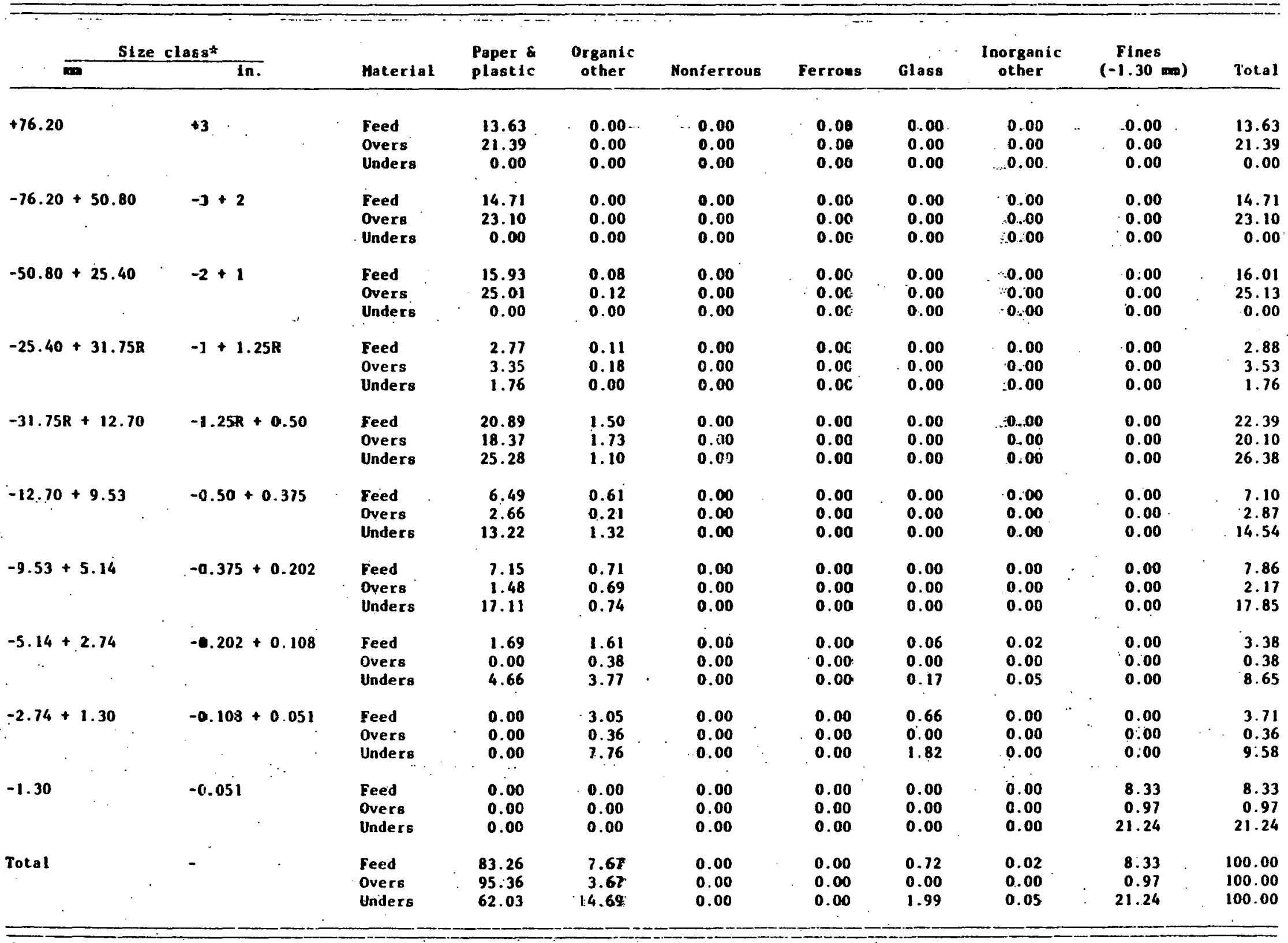

* R designates round sieve opening. 
TABIE B-42. COMPONENT/SIZE DISTRIBUTION (12 rpm, feedrate $=9.90 \mathrm{Hg} / \mathrm{h}(10.89 \mathrm{tons} / \mathrm{h})$, May 1981) (\% by weight)

\begin{tabular}{|c|c|c|c|c|c|c|c|c|c|c|}
\hline \multicolumn{2}{|c|}{ Size class* } & \multirow[b]{2}{*}{ Material } & \multirow{2}{*}{$\begin{array}{l}\text { Paper \& } \\
\text { plastic }\end{array}$} & \multirow{2}{*}{$\begin{array}{c}\text { Organic } \\
\text { other }\end{array}$} & \multirow[b]{2}{*}{ Nonferrous } & \multirow[b]{2}{*}{ Ferrous } & \multirow[b]{2}{*}{ Glass } & \multirow{2}{*}{$\begin{array}{l}\text { Inorganic } \\
\text { other }\end{array}$} & \multirow{2}{*}{$\begin{array}{c}\text { Fines } \\
(-1.30 \mathrm{man})\end{array}$} & \multirow[b]{2}{*}{ Total } \\
\hline $\mathbf{m m}$ & in. & & & & & & & & & \\
\hline \multicolumn{11}{|c|}{. } \\
\hline \multirow[t]{3}{*}{+76.20} & \multirow[t]{3}{*}{+3} & Feed & 1.01 & 0.00 & 0.00 & 0.00 & 0.00 & 0.00 & 0.00 & 1.01 \\
\hline & & Overs & 2.59 & 0.00 & 0.00 & 0.00 & 0.00 & 0.00 & 0.00 & 2.59 \\
\hline & & Unders & 0.00 & 0.00 & 0.00 & 0.00 & 0.00 & 0.00 & 0.00 & 0.00 \\
\hline \multirow[t]{3}{*}{$-76.20+50.80$} & \multirow[t]{3}{*}{$-3+2$} & Feed & 6.68 & 0.00 & 0.00 & 0.00 & 0.00 & 0.00 & 0.00 & 6.68 \\
\hline & & Overs & 17.18 & 0.00 & 0.00 & 0.00 & 0.00 & 0.00 & 0.00 & 17.18 \\
\hline & & Unders & 0.00 & 0.00 & 0.00 & 0.00 & 0.00 & 0.00 & 0.00 & 0.00 \\
\hline \multirow[t]{3}{*}{$-50.80+25.40$} & \multirow[t]{3}{*}{$-\tilde{z}+1$} & Feed & 12.55 & 0.05 & 0.00 & 0.00 & 0.00 & 0.00 & 0.00 & 12.60 \\
\hline & & Overs & 32.27 & 0.13 & 0.00 & 0.00 & 0.00 & 0.00 & 0.00 & 32.40 \\
\hline & & Unders & 0.00 & 0.00 & 0.00 & 0.00 & 0.00 & 0.00 & 0.00 & 0.00 \\
\hline \multirow{3}{*}{$-25.40+31.75 R$} & \multirow{3}{*}{$-1+1.25 R$} & Feed & 2.03 & 0.00 & 0.00 & 0.00 & 0.00 & 0.00 & 0.00 & 2.03 \\
\hline & & Overs & 3.63 & 0.00 & 0.00 & 0.00 & 0.00 & 0.00 & 0.00 & 3.63 \\
\hline & & Unders & 1.01 & 0.00 & 0.00 & 0.00 & 0.00 & 0.00 & 0.00 & 1.01 \\
\hline \multirow[t]{3}{*}{$-31.75 R+12.70$} & \multirow[t]{3}{*}{$-1.25 R+0.50$} & Feed & 15.58 & 0.48 & 0.16 & 0.00 & 0.00 & 0.00 & 0.00 & 16.22 \\
\hline & & Overs & 25.70 & 0.19 & 0.00 & 0.00 & 0.00 & 0.00 & 0.00 & 25.89 \\
\hline & & Unders & 9.14 & 0.66 & 0.26 & 0.00 & 0.00 & 0.00 & 0.00 & 10.06 \\
\hline \multirow{3}{*}{$-12.70+9.53$} & \multirow[t]{3}{*}{$-0.50+0.375$} & Feed & 7.33 & 0.62 & 0.00 & 0.00 & 0.00 & 0.00 & 0.00 & 7.95 \\
\hline & & Overs & 4.87 & 0.47 & 0.00 & 0.00 & 0.00 & 0.00 & 0.00 & 5.34 \\
\hline & & Unders & 8.90 & 0.71 & 0.00 & 0.00 & 0.00 & 0.00 & 0.00 & 9.61 \\
\hline \multirow[t]{3}{*}{$-9.53+5.14$} & \multirow[t]{3}{*}{$-0.375+0.202$} & Feed & 13.81 & 0.99 & 0.00 & 0.00 & 0.00 & 0.00 & 0.00 & 14.80 \\
\hline & & Overs & 5.13 & 0.43 & 0.00 & 0.00 & 0.00 & 0.00 & 0.00 & 5.56 \\
\hline & & Uuders & 19.33 & 1.35 & 0.00 & 0.00 & 0.00 & 0.00 & 0.00 & 20.68 \\
\hline+2.74 & $-0.202+0.108$ & Feed & 3.66 & 5.12 & 0.00 & 0.00 & 0.09 & 0.00 & 0.00 & 8.87 \\
\hline & & Overs & 0.00 & 1.55 & 0.00 & 0.00 & 0.00 & 0.00 & 0.00 & 1.55 \\
\hline & & Unders & 5.99 & 7.40 & 0.00 & 0.00 & 0.15 & 0.00 & 0.00 & 13.54 \\
\hline+1.30 & $-0.108+0.051$ & Feed & 0.00 & 8.41 & 0.00 & 0.00 & 1.40 & 0.06 & 0.00 & 9.87 \\
\hline & & Overs & 0.00 & 1.57 & 0.00 & 0.00 & 0.01 & 0.00 & 0.00 & 1.58 \\
\hline & & Unders & 0.00 & 12.77 & 0.00 & 0.00 & 2.28 & 0.10 & 0.00 & 15.15 \\
\hline & -0.051 & Feed & 0.00 & 0.00 & 0.00 & 0.00 & 0.00 & 0.00 & 19.97 & 19.97 \\
\hline & & Overs & 0.00 & 0.00 & 0.00 & 0.00 & 0.00 & 0.00 & 4.28 & 4.28 \\
\hline & & Unders & 0.00 & 0.00 & 0.00 & 0.00 & 0.00 & 0.00 & 29.95 & 29.95 \\
\hline &. & Feed & 62.65 & 15.67 & 0.16 & 0.00 & 1.49 & 0.06 & 19.97 & 100.00 \\
\hline & & Overs & 91.37 & 4.34 & 0.00 & 0.00 & 0.01 & 0.00 & 4.28 & 100.00 \\
\hline & & Unders & 44.37 & 22.89 & 0.26 & 0.00 & 2.43 & 0.10 & 29.95 & 100.00 \\
\hline
\end{tabular}

- R desiguales round sieve opening. 
TABLE B-43. COMPONENT/SIZE DISTRIIUTION $12 \mathrm{rpm}$, feedrate $=10.59 \mathrm{Hg} / \mathrm{h}(11.65 \mathrm{tons} / \mathrm{h})$, May 1981) ( $\mathrm{z}$ by $w \geqslant i \mathrm{ght}$ )

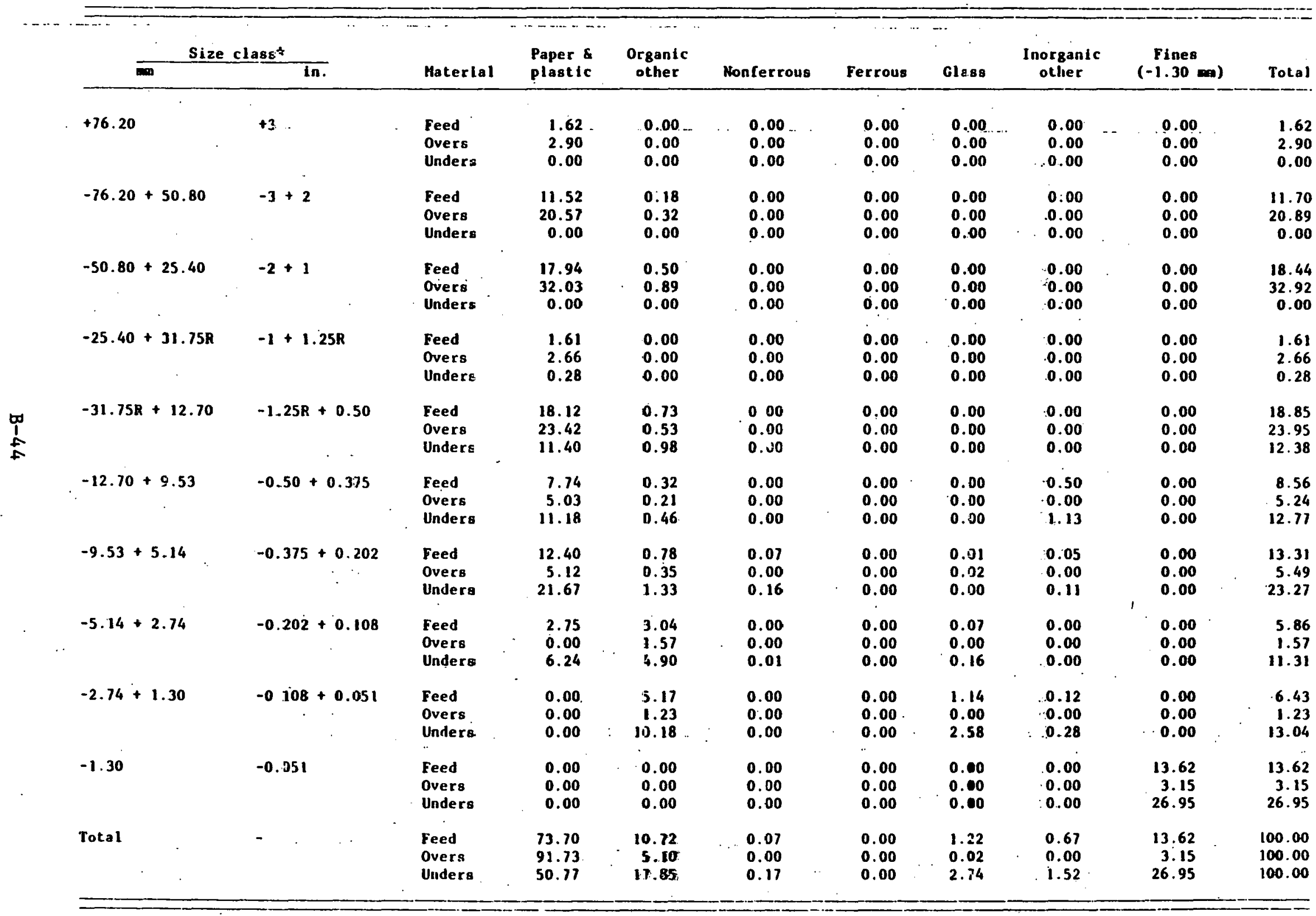

* R designates round sjeve operiing. 
TABIE B-44. COMPONENT/SIZE. DISTRIBUTION $(12 \mathrm{rmm}$; feedrate $=17.69 \mathrm{Hg} / \mathrm{h}(19.46$ tons $/ \mathrm{h})$, May 1981$)$ (\% liy weight)

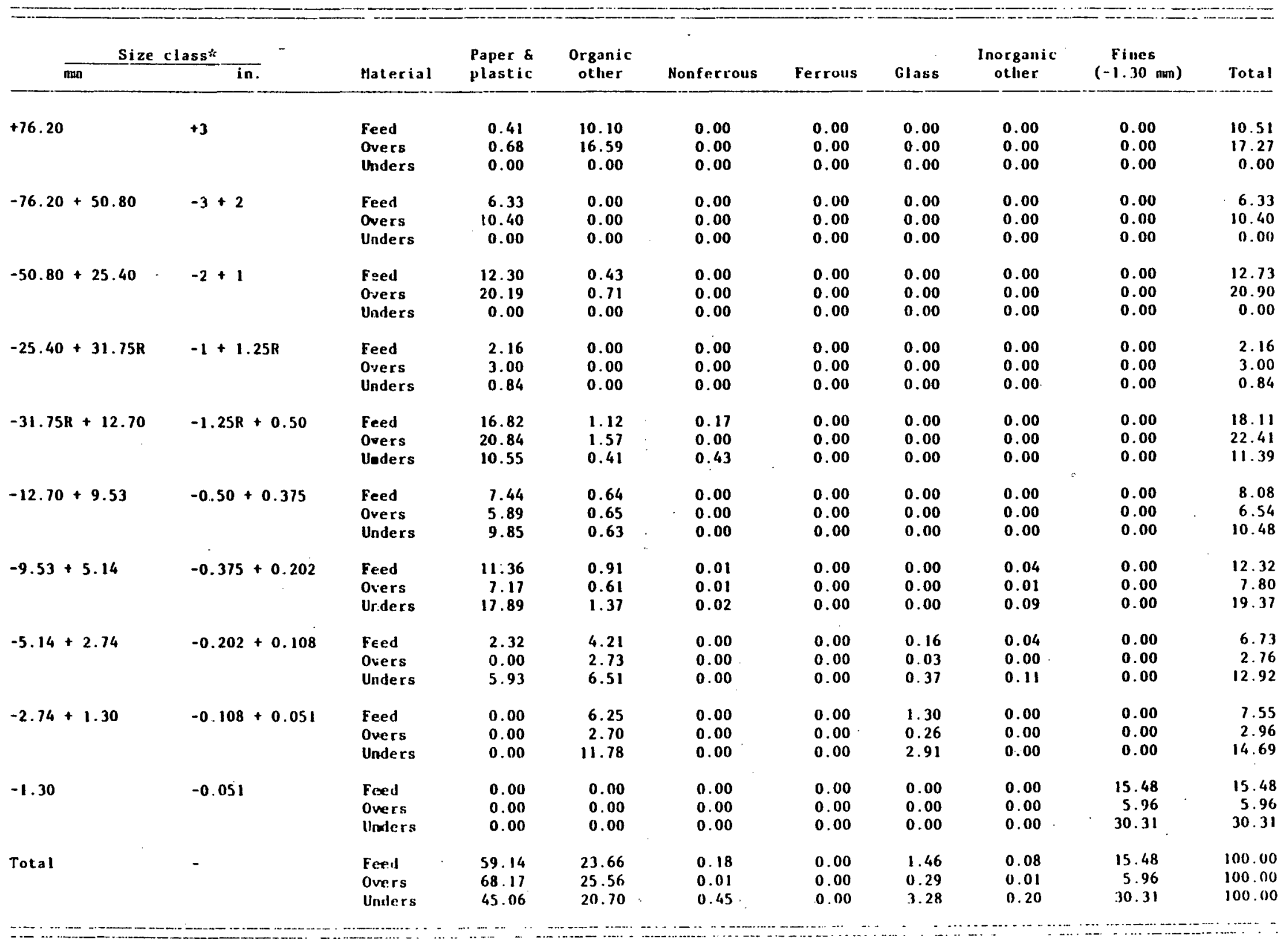

* R designales round sieve opening. 
TABLE B-45. COMFONENT/SIZE DISTRIBUTION (12 $\mathrm{rpm}, 46.55 \mathrm{Mg} / \mathrm{h}$ (51.20 tons/h), May 1981)

( $\mathrm{T}$. by weight)

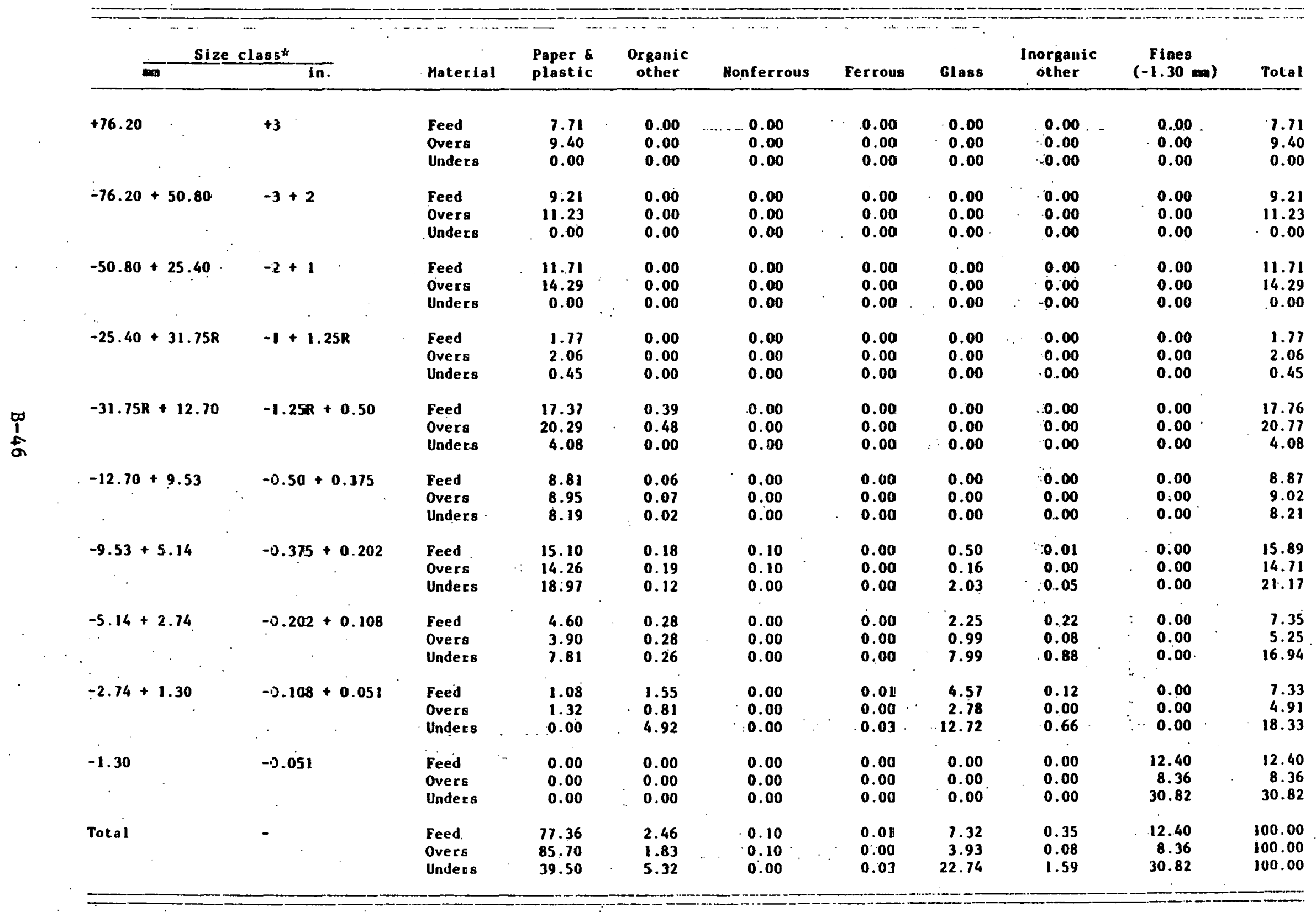

* R designates round sieve opening. 
TABI.E B-46. COMPONENT/SIZE. DISTRIBUTION (6 $\mathrm{rpm}$, feelirate $=2.64 \mathrm{Hg} / \mathrm{h}(2.90 \mathrm{tons} / \mathrm{h})$, Algust 1981) ( $\%$ by weight)

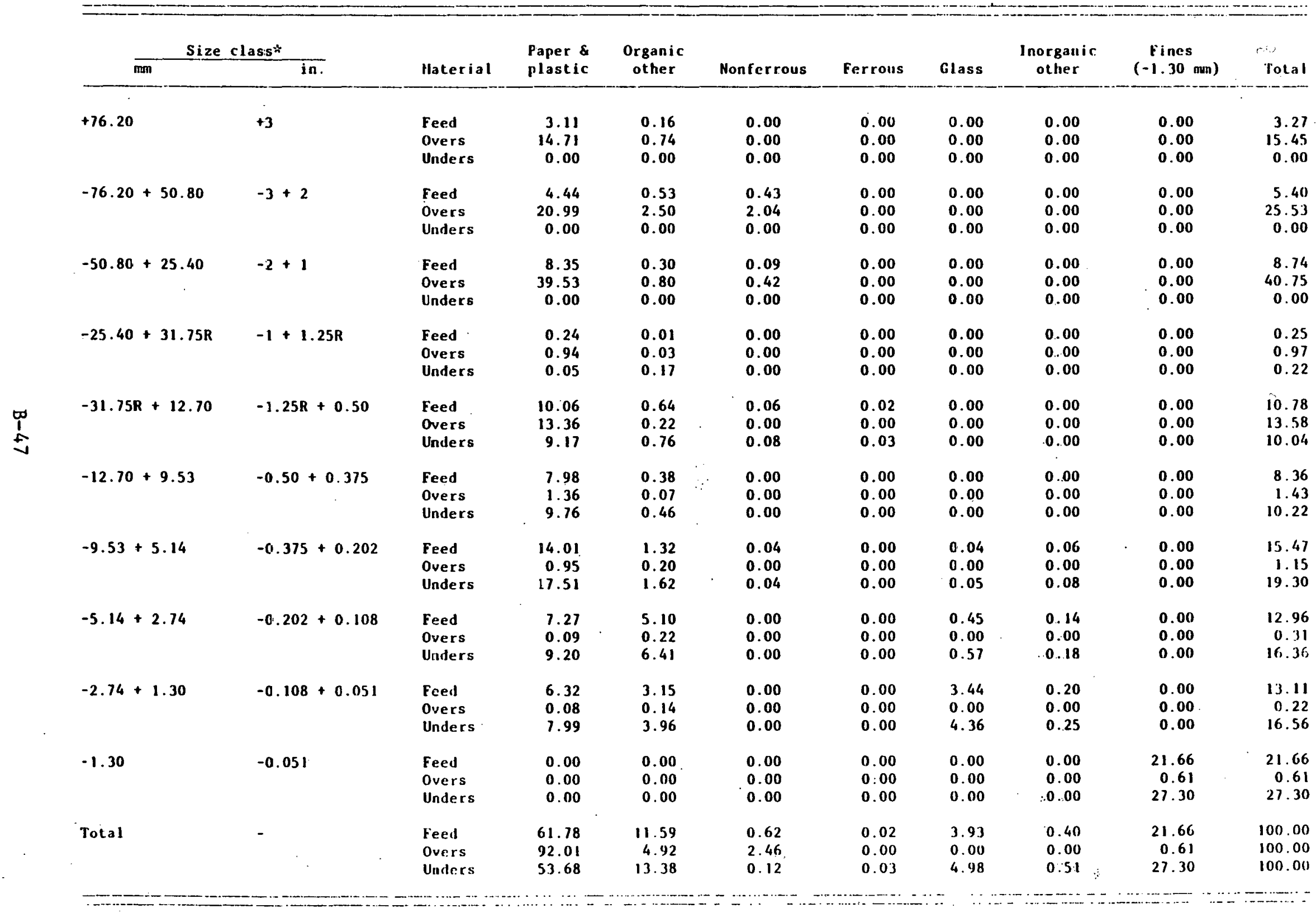

$\therefore \quad R$ designates round sieve opening 
TABLE B-47. COMPONENT/SIZE CISTRIBUTION (6 $\mathrm{cpm}$, feedrate $=3.56 \mathrm{Ng} / \mathrm{h}(3.92 \mathrm{tonis} / \mathrm{h})$, August $198 \mathrm{l})$ ( $\%$ by weight)

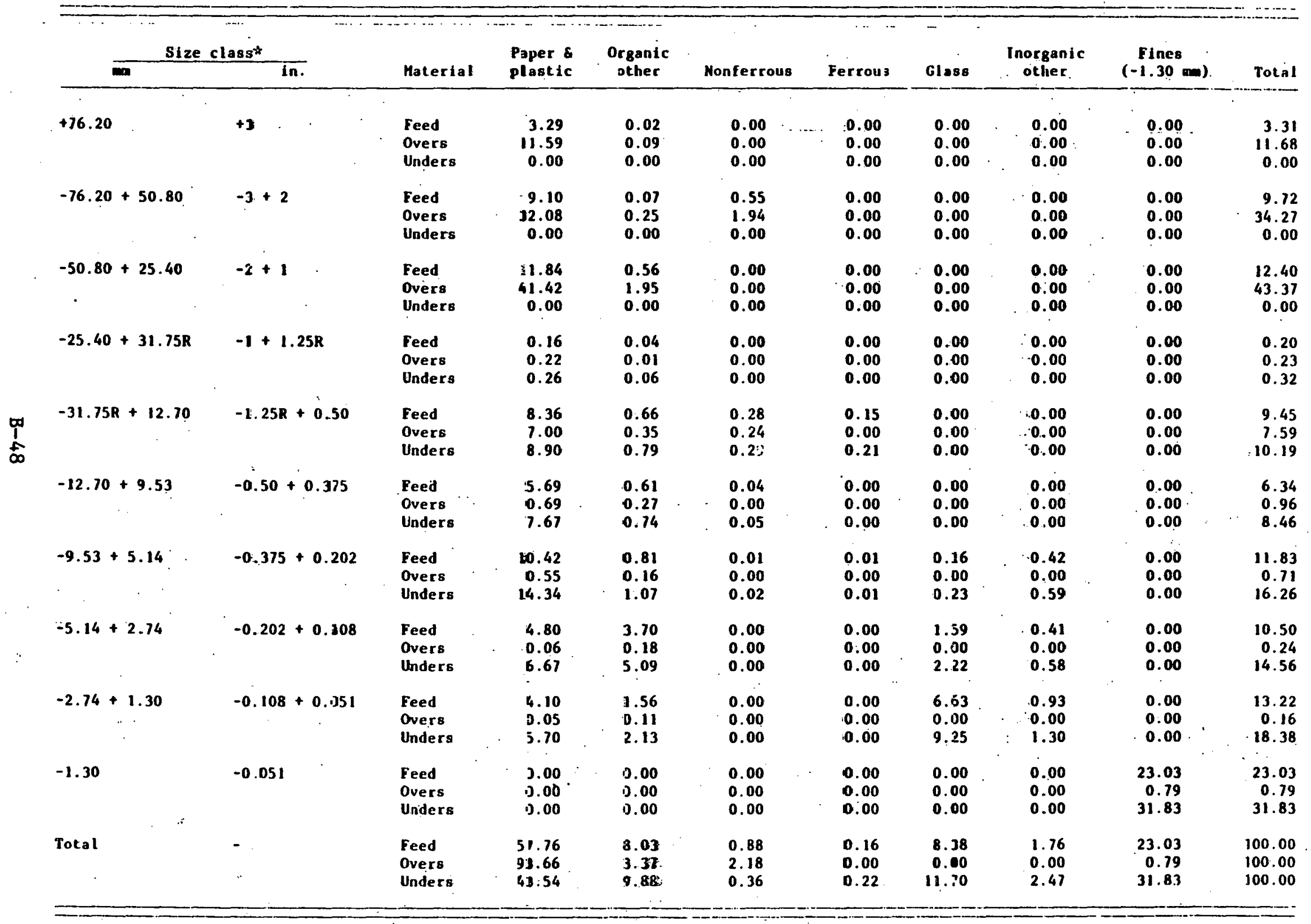

* $R$ designates round sleve opening 
TABLE B-48. COHPONENT/SIZE DISTRIBUTION $(6 \mathrm{rpm}$, feedrale $=7.80 \mathrm{Mg} / \mathrm{h}(8.58 \mathrm{tons} / \mathrm{h})$, August 1981$)$ iq by weight).

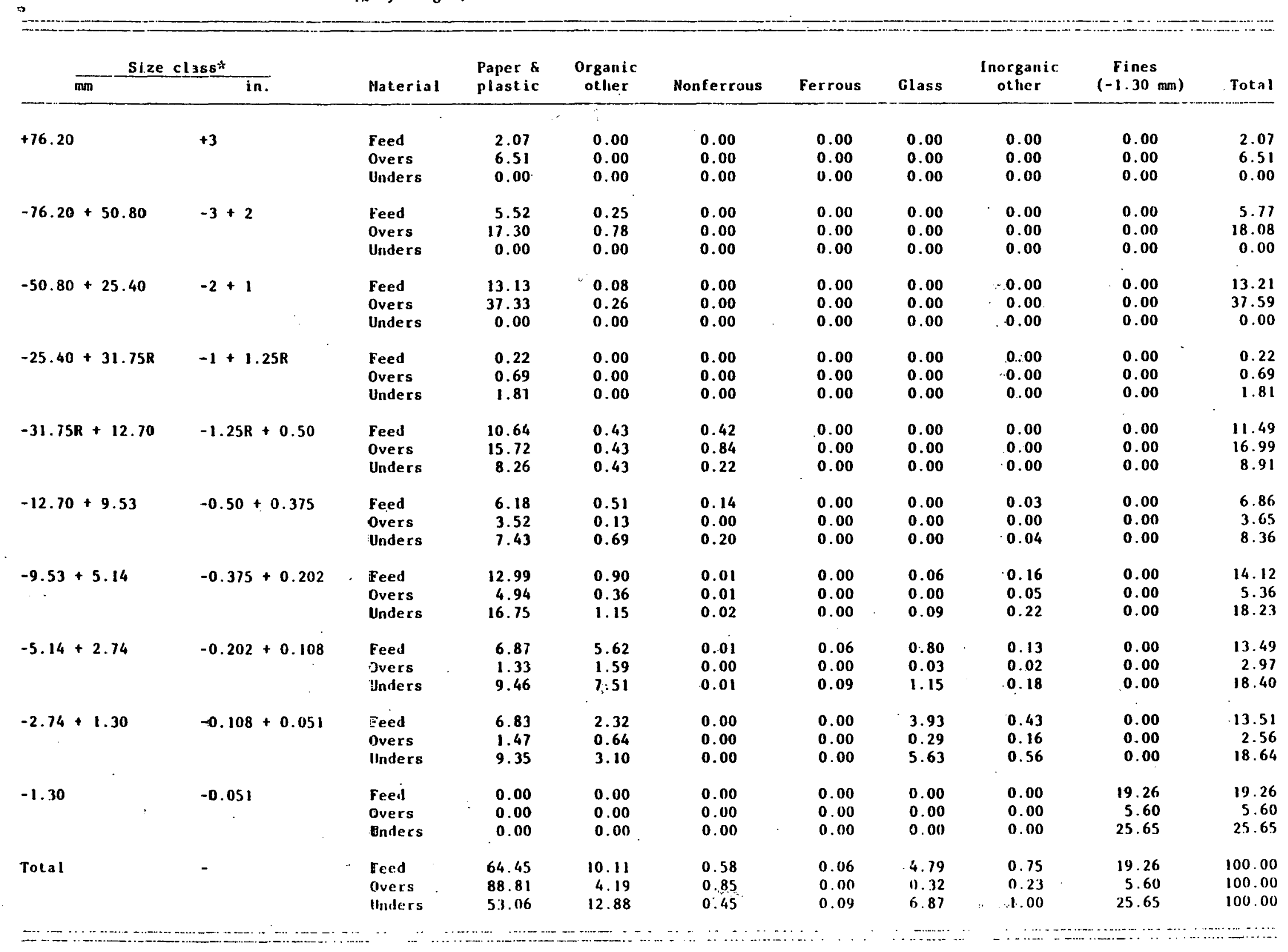

$\therefore$ R tesiguates rounl sieve opcniug. 
TABIE E-49. COMPONENT/SIZE DISTFIBUTION (6 rpw, feedrate $=10.63 \cdot \mathrm{Hg} / \mathrm{h}(11.69$ Lons/h), August 1981 ) (4 by wejgrt)

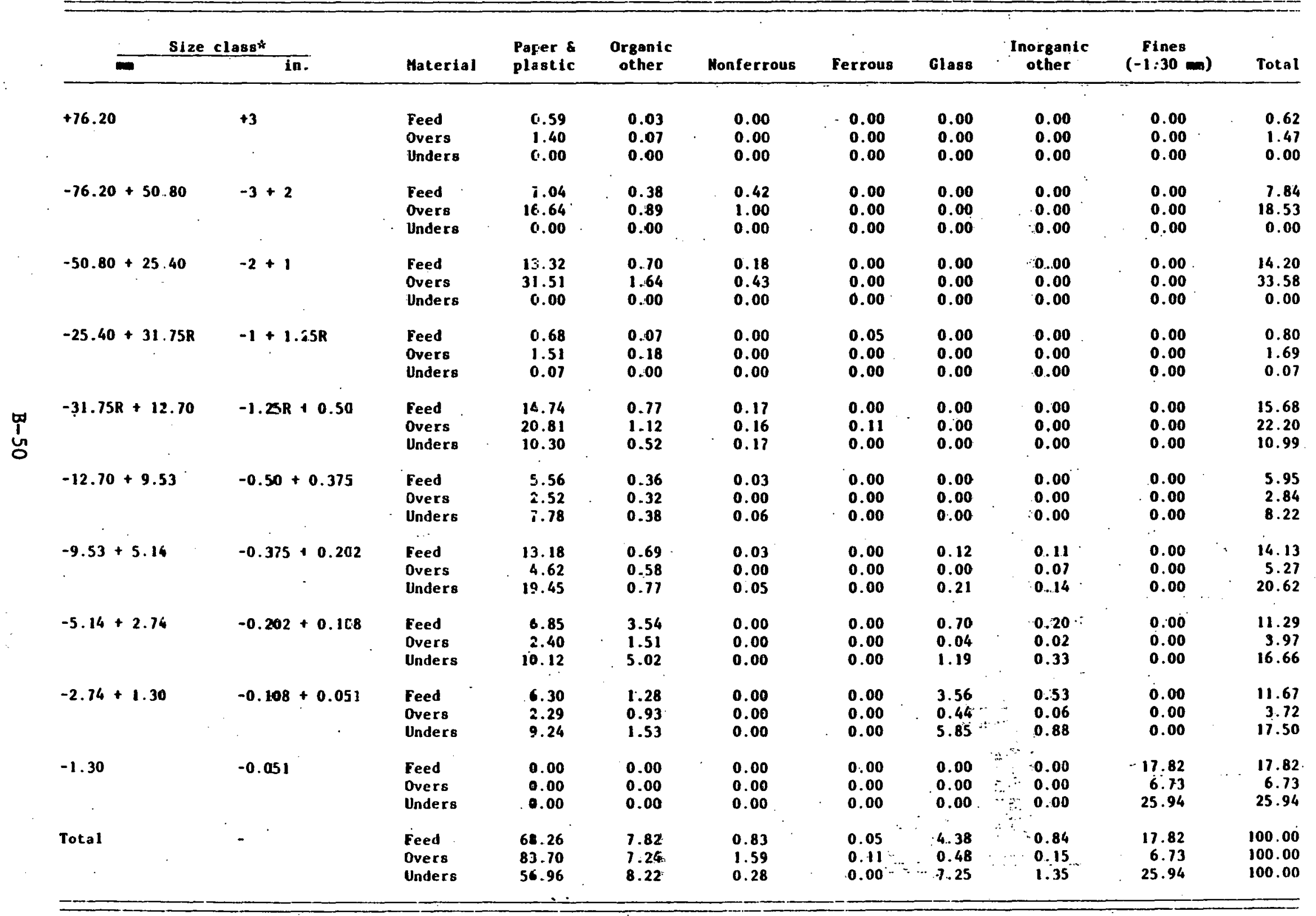


TABLE B-50. COMPONENT/SIZE DISTRIBUTION (6 rpn, feedrate $=23.26 \mathrm{Hg} / \mathrm{h}(25.59 \mathrm{tons} / \mathrm{h})$, August 198I) (\% by weight).

\begin{tabular}{|c|c|c|c|c|c|c|c|c|c|c|c|}
\hline \multicolumn{3}{|c|}{ Size classt } & \multirow{2}{*}{ Material } & \multirow{2}{*}{$\begin{array}{l}\text { Paper \& } \\
\text { plastic }\end{array}$} & \multirow{2}{*}{$\begin{array}{c}\text { Organic } \\
\text { other }\end{array}$} & \multirow[b]{2}{*}{ Nonferrous } & \multirow[b]{2}{*}{ Ferrous } & \multirow{2}{*}{ Glass } & \multirow{2}{*}{$\begin{array}{l}\text { Inorganic } \\
\text { other }\end{array}$} & \multirow{2}{*}{$\begin{array}{c}\text { Fines } \\
(-1.30 \text { min })\end{array}$} & \multirow[b]{2}{*}{ Total } \\
\hline & mก & in. & & & & & & & & & \\
\hline+76.20 & & +3 & $\begin{array}{l}\text { Feed } \\
\text { Overs } \\
\text { Unders }\end{array}$ & $\begin{array}{l}6.69 \\
9.80 \\
0.00\end{array}$ & $\begin{array}{l}0.00 \\
0.00 \\
0.00\end{array}$ & $\begin{array}{l}0.00 \\
0.00 \\
0.00\end{array}$ & $\begin{array}{l}0.00 \\
0.00 \\
0.00\end{array}$ & $\begin{array}{l}0.00 \\
0.00 \\
0.00\end{array}$ & $\begin{array}{l}0.00 \\
0.00 \\
0.00\end{array}$ & $\begin{array}{l}0.00 \\
0.00 \\
0.00\end{array}$ & $\begin{array}{l}6.69 \\
9.80 \\
0.00\end{array}$ \\
\hline-76.20 & +50.80 & $-3+2$ & $\begin{array}{l}\text { Feed } \\
\text { Overs } \\
\text { Unders }\end{array}$ & $\begin{array}{l}6.52 \\
9.54 \\
0.00\end{array}$ & $\begin{array}{l}0.05 \\
0.07 \\
0.00\end{array}$ & $\begin{array}{l}0.54 \\
0.79 \\
0.00\end{array}$ & $\begin{array}{l}0.00 \\
0.00 \\
0.00\end{array}$ & $\begin{array}{l}0.00 \\
0.00 \\
0.00\end{array}$ & $\begin{array}{l}0.00 \\
0.00 \\
0.00\end{array}$ & $\begin{array}{l}0.00 \\
0.00 \\
0.00\end{array}$ & $\begin{array}{r}7.11 \\
10.40 \\
0.00\end{array}$ \\
\hline-50.80 & +25.40 & $-2+1$ & $\begin{array}{l}\text { Feed } \\
\text { Overs } \\
\text { Unders }\end{array}$ & $\begin{array}{r}12.63 \\
18.49 \\
0.00\end{array}$ & $\begin{array}{l}2.47 \\
3.62 \\
0.00\end{array}$ & $\begin{array}{l}0.00 \\
0.00 \\
0.00\end{array}$ & $\begin{array}{l}0.00 \\
0.00 \\
0.00\end{array}$ & $\begin{array}{l}0.00 \\
0.00 \\
0.00\end{array}$ & $\begin{array}{r}0.00 \\
0.00 \\
0.00\end{array}$ & $\begin{array}{l}0.00 \\
0.00 \\
0.00\end{array}$ & $\begin{array}{r}15.10 \\
22.11 \\
0.00\end{array}$ \\
\hline-25.40 & $+31.75 R$ & $-1+1.25 R$ & $\begin{array}{l}\text { Feed } \\
\text { Overs } \\
\text { Unders }\end{array}$ & $\begin{array}{l}0.72 \\
1.03 \\
0.04\end{array}$ & $\begin{array}{l}0.05 \\
0.07 \\
0.00\end{array}$ & $\begin{array}{l}0.00 \\
0.00 \\
0.00\end{array}$ & $\begin{array}{l}0.00 \\
0.00 \\
0.00\end{array}$ & $\begin{array}{l}0.00 \\
0.00 \\
0.00\end{array}$ & $\begin{array}{l}0.00 \\
0.00 \\
0.00\end{array}$ & $\begin{array}{l}0.00 \\
0.00 \\
0.00\end{array}$ & $\begin{array}{l}0.77 \\
1.10 \\
0.04\end{array}$ \\
\hline$-31.75 R$ & $R+12.70$ & $\begin{array}{c}-1.25 R+0.50 \\
.\end{array}$ & $\begin{array}{l}\text { Feed } \\
\text { Overs } \\
\text { Unders }\end{array}$ & $\begin{array}{r}10.90 \\
13.65 \\
4.98\end{array}$ & $\begin{array}{l}0.85 \\
1.15 \\
0.22\end{array}$ & $\begin{array}{l}0.03 \\
0.04 \\
0.00\end{array}$ & $\begin{array}{l}0.00 \\
0.00 \\
0.00\end{array}$ & $\begin{array}{l}0.00 \\
0.00 \\
0.00\end{array}$ & $\begin{array}{l}0.00 \\
0.00 \\
0.00\end{array}$ & $\begin{array}{l}0.00 \\
0.00 \\
0.00\end{array}$ & $\begin{array}{r}11.78 \\
14.84 \\
5.20\end{array}$ \\
\hline-12.70 & +9.53 & $-0.50+0.375$ & $\begin{array}{l}\text { Feed } \\
\text { Overs } \\
\text { Unders }\end{array}$ & $\begin{array}{l}4.16 \\
3.49 \\
5.63\end{array}$ & $\begin{array}{l}10.49 \\
0.57 \\
0.32\end{array}$ & $\begin{array}{l}0.03 \\
0.03 \\
0.03\end{array}$ & $\begin{array}{l}0.00 \\
0.00 \\
0.00\end{array}$ & $\begin{array}{l}0.00 \\
0.00 \\
0.00\end{array}$ & $\begin{array}{l}0.00 \\
0.00 \\
0.00\end{array}$ & $\begin{array}{l}0.00 \\
0.00 \\
0.00\end{array}$ & $\begin{array}{l}4.68 \\
4.09 \\
5.98\end{array}$ \\
\hline$-9.53+$ & +5.14 & $-0.375+0.202$ & $\begin{array}{l}\text { Feed } \\
\text { Overs } \\
\text { Unders }\end{array}$ & $\begin{array}{r}9.85 \\
8.48 \\
12.80\end{array}$ & $\begin{array}{l}0.81 \\
0.70 \\
1.06\end{array}$ & $\begin{array}{l}0.03 \\
0.01 \\
0.07\end{array}$ & $\begin{array}{l}0.00 \\
0.00 \\
0.00\end{array}$ & $\begin{array}{l}0.20 \\
0.00 \\
0.63\end{array}$ & $\begin{array}{l}0.14 \\
.0 .05 \\
0.33\end{array}$ & $\begin{array}{l}0.00 \\
0.00 \\
0.00\end{array}$ & $\begin{array}{r}11.03 \\
9.24 \\
14.89\end{array}$ \\
\hline$-5.14+$ & +2.74 & $-0.202+0.108$ & $\begin{array}{l}\text { Feed } \\
\text { Overs } \\
\text { Unders }\end{array}$ & $\begin{array}{l}5.93 \\
4.08 \\
9.92\end{array}$ & $\begin{array}{l}3.66 \\
3.53 \\
3.92\end{array}$ & $\begin{array}{l}0.00 \\
0.00 \\
0.00\end{array}$ & $\begin{array}{l}0.00 \\
0.00 \\
0.00\end{array}$ & $\begin{array}{l}1.55 \\
0.25 \\
4.34\end{array}$ & $\begin{array}{l}0.21 \\
0.07 \\
0.53\end{array}$ & $\begin{array}{l}0.00 \\
0.00 \\
0.00\end{array}$ & $\begin{array}{r}11.35 \\
7.93 \\
18.71\end{array}$ \\
\hline$-2.74+$ & +1.30 & $-0.108+0.051$ & $\begin{array}{l}\text { Feed } \\
\text { Overs } \\
\text { Unders }\end{array}$ & $\begin{array}{l}5.47 \\
3.65 \\
9.38\end{array}$ & $\begin{array}{l}1.87 \\
2.00 \\
1.59\end{array}$ & $\begin{array}{l}0.00 \\
0.00 \\
0.00\end{array}$ & $\begin{array}{l}0.00 \\
0.00 \\
0.00\end{array}$ & $\begin{array}{r}3.96 \\
1.13 \\
10.06\end{array}$ & $\begin{array}{r}0.45 \\
0.20 \\
0.98\end{array}$ & $\begin{array}{l}0.00 \\
0.00 \\
0.00\end{array}$ & $\begin{array}{r}11.75 \\
6.98 \\
22.01\end{array}$ \\
\hline-1.30 & $\cdot$ & $-0.05 t$ & $\begin{array}{l}\text { Feed } \\
\text { Overs } \\
\text { Unders }\end{array}$ & $\begin{array}{l}0.00 \\
0.00 \\
0.00\end{array}$ & $\begin{array}{l}0.00 \\
0.00 \\
0.00\end{array}$ & $\begin{array}{l}0.00 \\
0.00 \\
0.00\end{array}$ & $\begin{array}{l}0.00 \\
0.00 \\
0.00\end{array}$ & $\begin{array}{l}0.00 \\
0.00 \\
0.00\end{array}$ & $\begin{array}{l}0.00 \\
0.00 \\
0.00\end{array}$ & $\begin{array}{l}19.74 \\
13.51 \\
33.17\end{array}$ & $\begin{array}{l}19.74 \\
13.51 \\
33.17\end{array}$ \\
\hline Total & & - & $\begin{array}{l}\text { Feed } \\
\text { Overs } \\
\text { Unders }\end{array}$ & $\begin{array}{l}62.87 \\
72.21 \\
42.75\end{array}$ & $\begin{array}{r}10.25 \\
11.71 \\
7.11\end{array}$ & $\begin{array}{l}0.63 \\
0.87 \\
0.10\end{array}$ & $\begin{array}{l}0.00 \\
0.00 \\
0.00\end{array}$ & $\begin{array}{r}5.71 \\
1.38 \\
15.03\end{array}$ & $\begin{array}{r}0.80 \\
0.32 \\
.1 .84\end{array}$ & $\begin{array}{l}19.74 \\
13.51 \\
33.17\end{array}$ & $\begin{array}{l}100.00 \\
100.00 \\
100.00\end{array}$ \\
\hline
\end{tabular}

\footnotetext{
$\therefore$ R desighales cound sieve openillg.
} 
TABLE B-51. COMPONENT/SIEE DISTRIBUT:ION (9 rpw, fcedrate $=1.47 \mathrm{Hg} / \mathrm{h}(1.62 \mathrm{tons} / \mathrm{h})$, August 1981)

( $\%$ by weight)

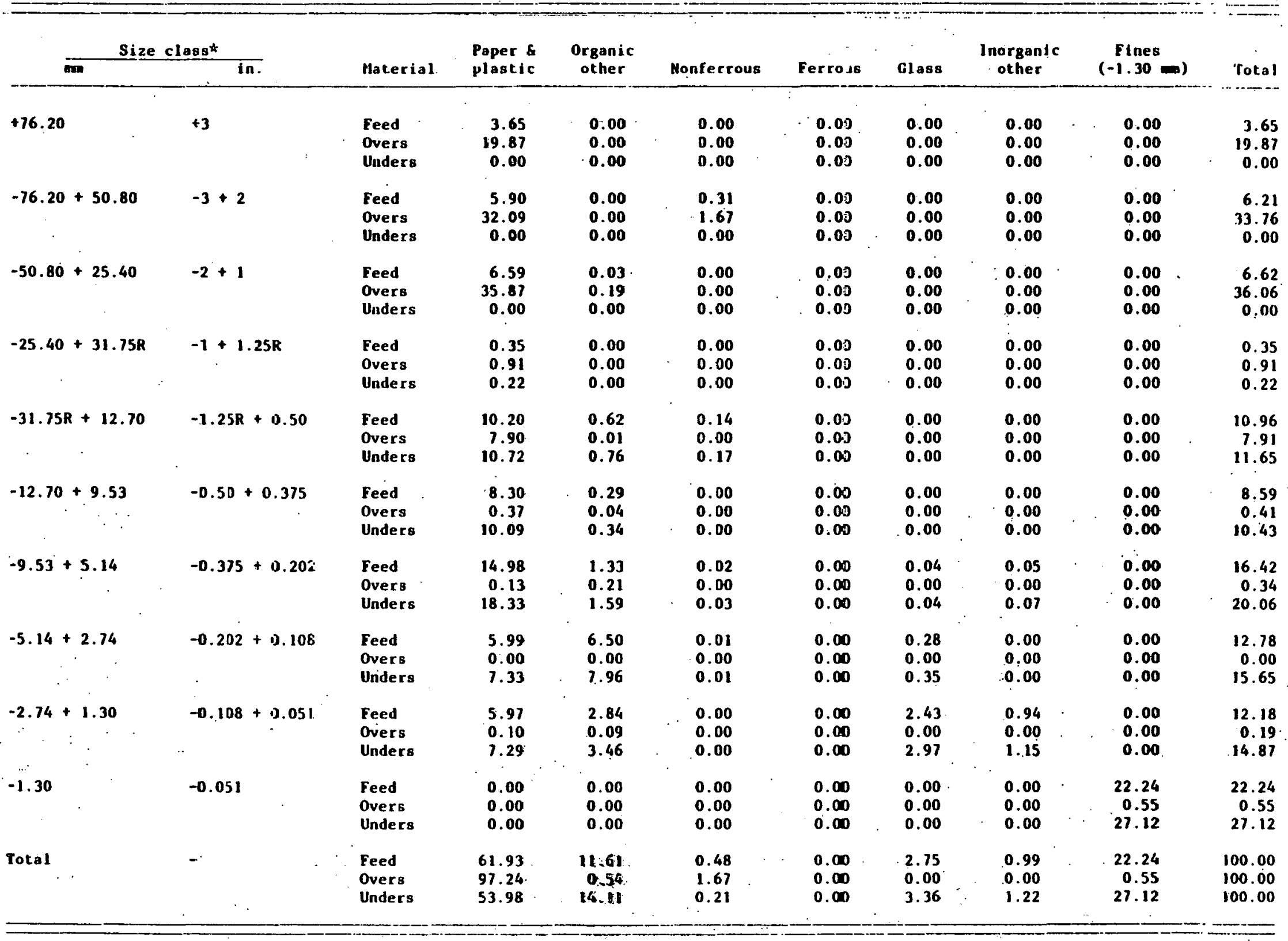

* $R$ desiguates round sieve o,reniuz. 
TABIE B-52. COHPONENT/SIZE DISTRIBUTION (9 rpn, Feedrate $=6.91 \mathrm{Mg} / \mathrm{h}(7.60 \mathrm{tons} / \mathrm{h}$ ), August 1981$)$ (\% by we ight)

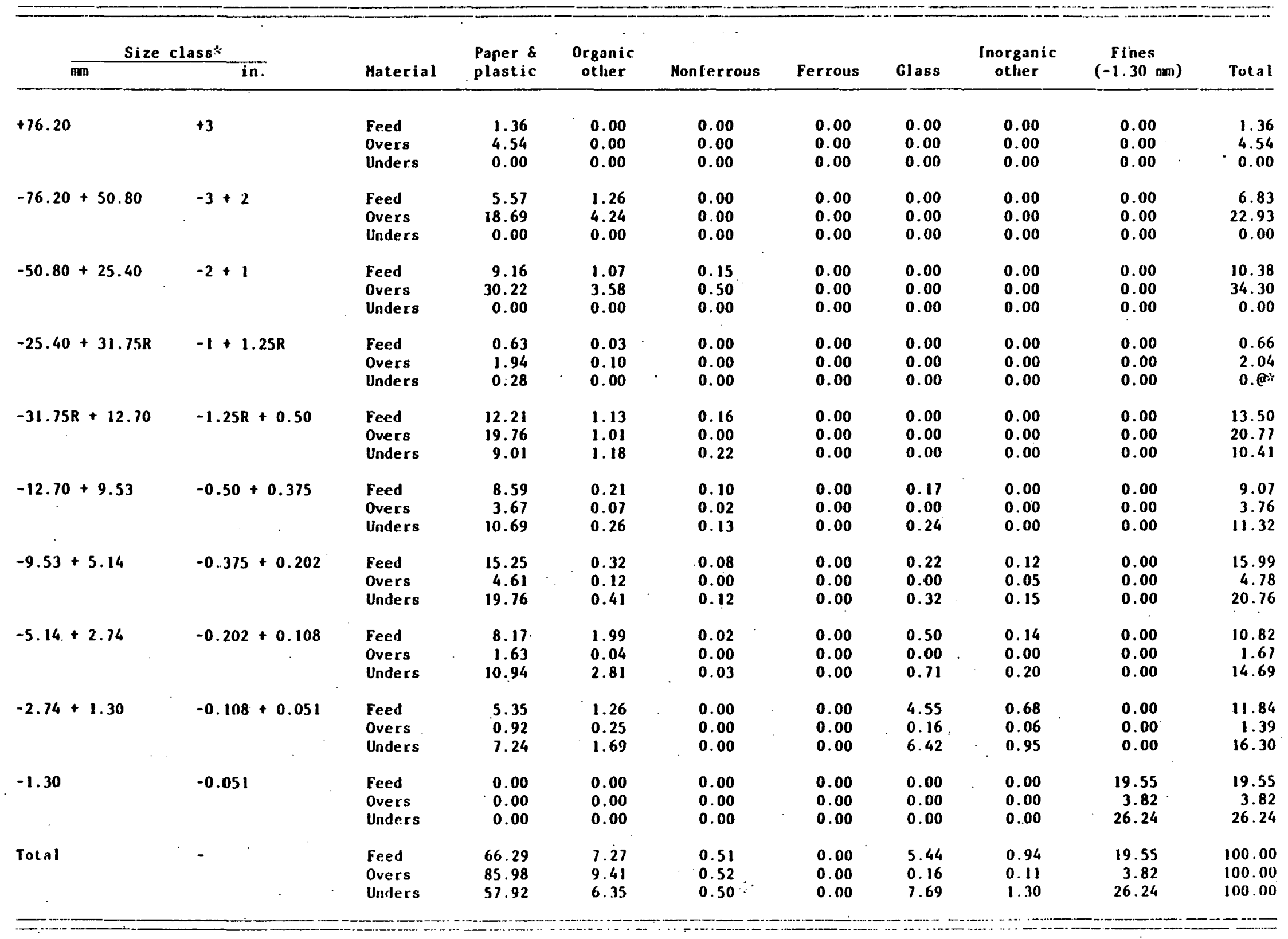

$\therefore$ - designates round sieve opening. 
TABLE B-53. COAPONENT/SIZE DISTRIBUTION ( $9 \mathrm{rpa}$, fecdrate $=\cdot 10.17 \mathrm{Hg} / \mathrm{h}(11.19 \mathrm{lons} / \mathrm{h})$, August 1981) (\% by weight)

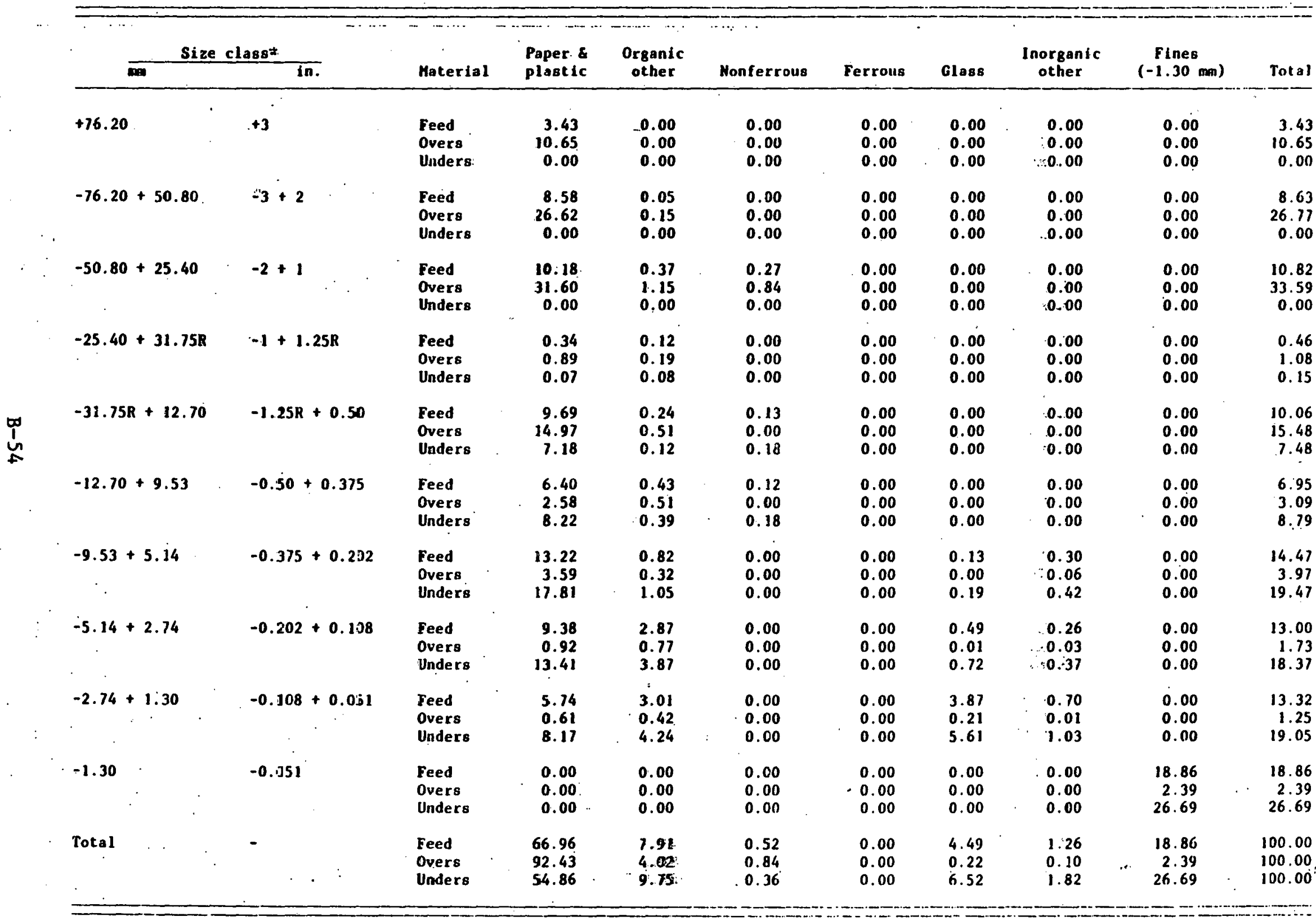

\footnotetext{
* $R$ designates round sieve opening.
} 
TABLF, B-54. COMPONENT/SIZE DISTRIBUTION $(9 \mathrm{rpm}$, feedrate $=12.71 \mathrm{Hg} / \mathrm{h}(13.98 \mathrm{tons} / \mathrm{h})$, August $198 \mathrm{I})$

(\% by weight)

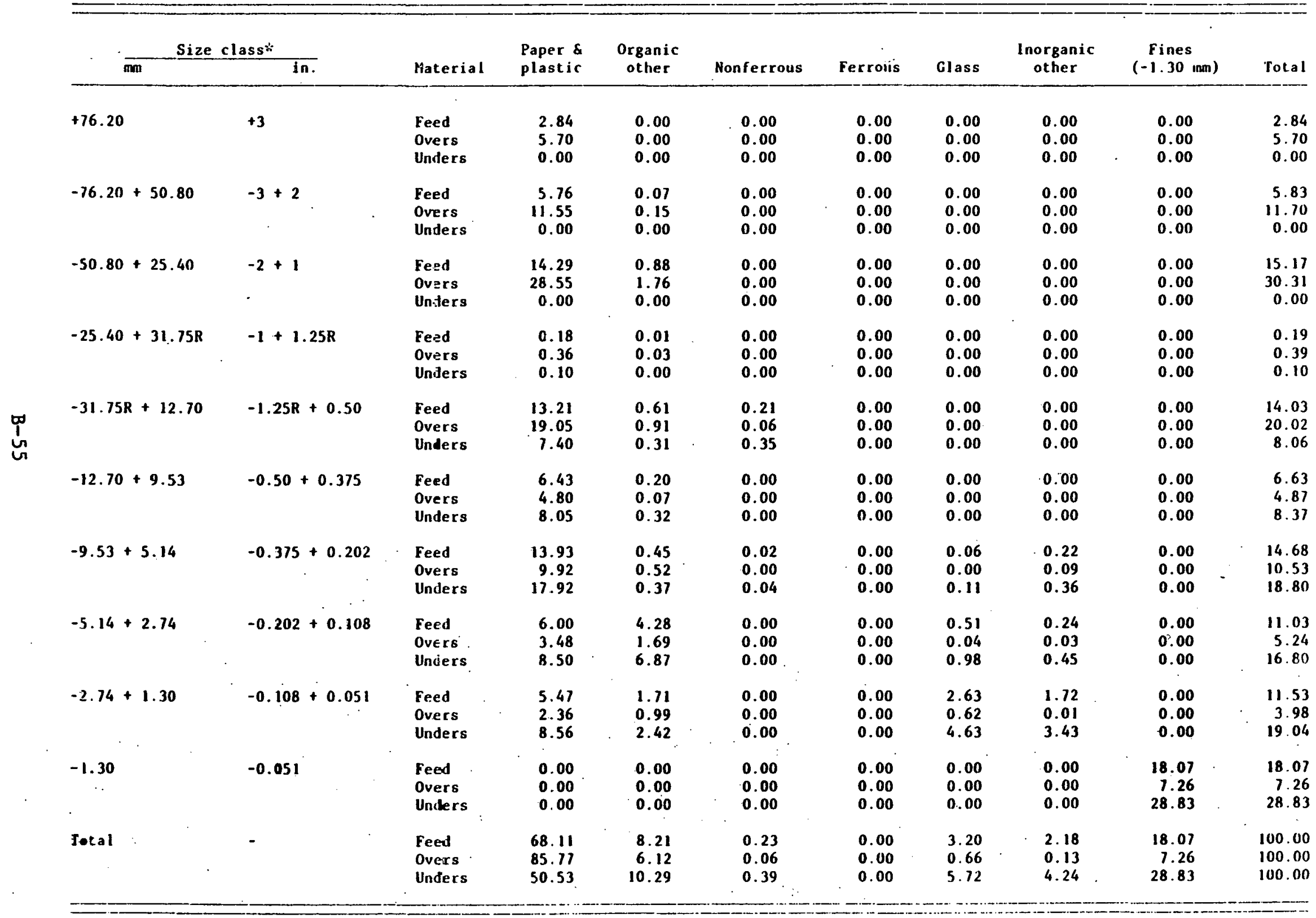

* R designales round sieve opening. 
TABLE B-55. COIPONENT/SIZF. IISTRIBUTION ( $9 \mathrm{rpm}$, feedrate $=33.28 \mathrm{Hg} / \mathrm{h}(3 j .61$ tons/h), August 1981) (\% by weiglit)

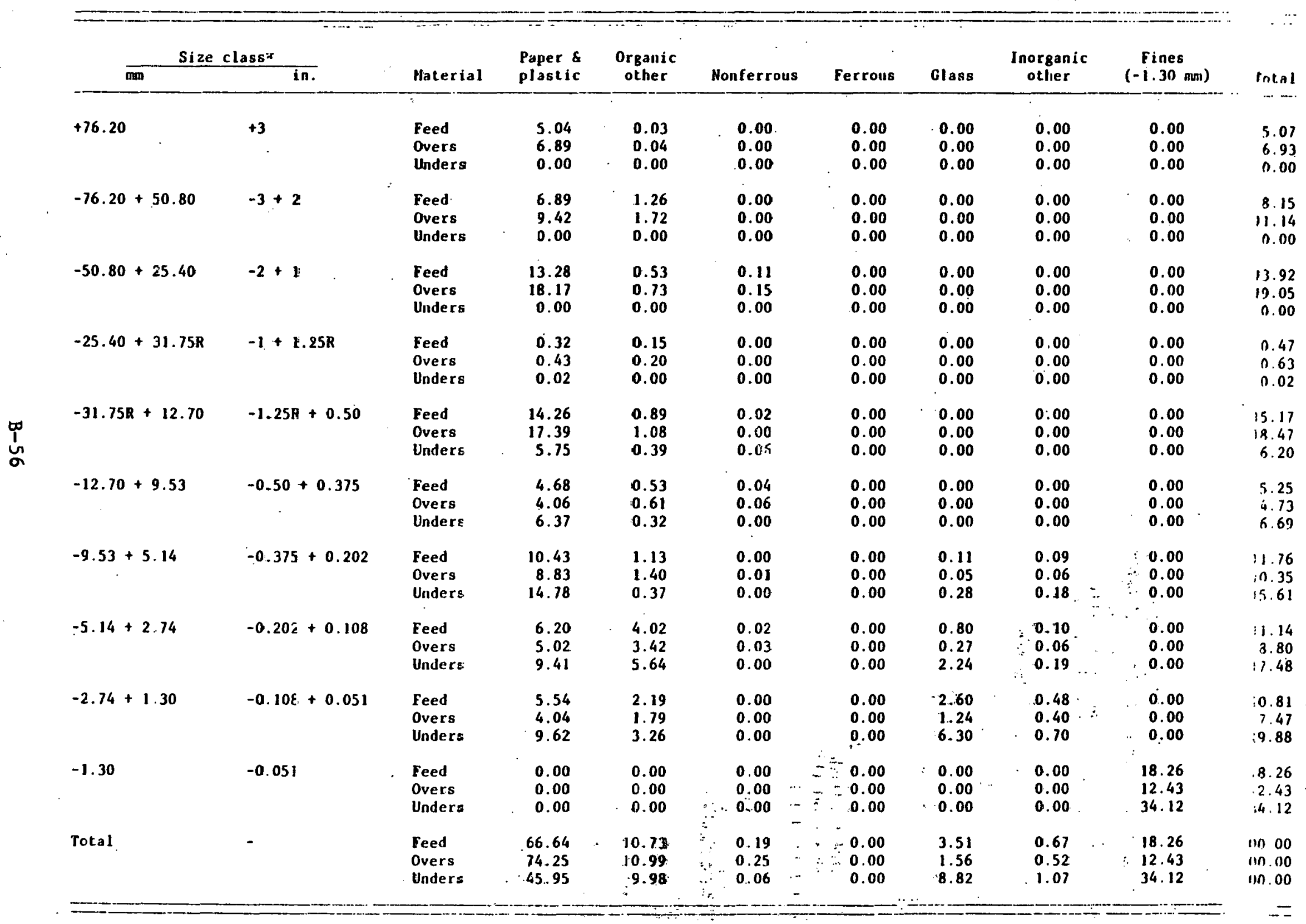

* R designates round sieve opening. 
TABLE B-56. COMPONENT/SIZE DISTRIBUTION $(12 \mathrm{rpm}$, feellrate $=2.41 \mathrm{Hg} / \mathrm{h}(2.65$ Lons $/ \mathrm{h})$, August 1981)

\section{(\% by weight)}

\begin{tabular}{|c|c|c|c|c|c|c|c|c|c|c|c|}
\hline & Size & class $* \frac{}{\text { in. }}$ & Material & $\begin{array}{l}\text { Paper \& } \\
\text { plastic }\end{array}$ & $\begin{array}{c}\text { Organic } \\
\text { other }\end{array}$ & Nonferrous & Ferrous & Glass & $\begin{array}{c}\text { Inorganic } \\
\text { other }\end{array}$ & $\begin{array}{l}\text { Fines } \\
(-1.30 \mathrm{~nm})\end{array}$ & Total \\
\hline+76.20 & & +3 & $\begin{array}{l}\text { Feed } \\
\text { Overs } \\
\text { Unders }\end{array}$ & $\begin{array}{l}2.00 \\
8.59 \\
0.00\end{array}$ & $\begin{array}{l}0.00 \\
0.00 \\
0.00\end{array}$ & $\begin{array}{l}0.00 \\
0.00 \\
0.00\end{array}$ & $\begin{array}{l}0.00 \\
0.00 \\
0.00\end{array}$ & $\begin{array}{l}0.00 \\
0.00 \\
0.00\end{array}$ & $\begin{array}{l}0.00 \\
0.00 \\
0.00\end{array}$ & $\begin{array}{l}0.00 \\
0.00 \\
0.00\end{array}$ & $\begin{array}{l}2.00 \\
8.59 \\
0.00\end{array}$ \\
\hline-76.20 & +50.80 & $-3+2$ & $\begin{array}{l}\text { Feed } \\
\text { Overs } \\
\text { Unders }\end{array}$ & $\begin{array}{r}6.20 \\
26.67 \\
0.00\end{array}$ & $\begin{array}{l}0.33 \\
1.42 \\
0.00\end{array}$ & $\begin{array}{l}0.65 \\
2.80 \\
0.00\end{array}$ & $\begin{array}{l}0.00 \\
0.00 \\
0.00\end{array}$ & $\begin{array}{l}0.00 \\
0.00 \\
0.00\end{array}$ & $\begin{array}{l}0.00 \\
0.00 \\
0.00\end{array}$ & $\begin{array}{l}0.00 \\
0.00 \\
0.00\end{array}$ & $\begin{array}{r}7.18 \\
30.89 \\
0.00\end{array}$ \\
\hline-50.80 & +25.40 & $-2+1$ & $\begin{array}{l}\text { Feed } \\
\text { Overs } \\
\text { Unders }\end{array}$ & $\begin{array}{r}9.94 \\
41.71 \\
0.00\end{array}$ & $\begin{array}{l}1.86 \\
3.65 \\
0.00\end{array}$ & $\begin{array}{l}0.31 \\
1.32 \\
0.00\end{array}$ & $\begin{array}{l}0.00 \\
0.00 \\
0.00\end{array}$ & $\begin{array}{l}0.00 \\
0.00 \\
0.00\end{array}$ & $\begin{array}{l}0.00 \\
0.00 \\
0.00\end{array}$ & $\begin{array}{l}0.00 \\
0.00 \\
0.00\end{array}$ & $\begin{array}{r}12.10 \\
46.68 \\
0.00\end{array}$ \\
\hline-25.40 & $+31.75 R$ & $-1+1.25 R$ & $\begin{array}{l}\text { Feed } \\
\text { Overs } \\
\text { Unders }\end{array}$ & $\begin{array}{l}0.58 \\
1.61 \\
0.58\end{array}$ & $\begin{array}{l}0.28 \\
0.06 \\
1.67\end{array}$ & $\begin{array}{l}0.00 \\
0.00 \\
0.00\end{array}$ & $\begin{array}{l}0.00 \\
0.00 \\
0.00\end{array}$ & $\begin{array}{l}0.00 \\
0.00 \\
0.00\end{array}$ & $\begin{array}{l}0.00 \\
0.00 \\
0.00\end{array}$ & $\begin{array}{l}0.00 \\
0.00 \\
0.00\end{array}$ & $\begin{array}{l}0.86 \\
1.67 \\
2.25\end{array}$ \\
\hline$-31.75 f$ & $R+12.70$ & $-1.25 R+0.50$ & $\begin{array}{l}\text { Feed } \\
\text { Overs } \\
\text { Unders }\end{array}$ & $\begin{array}{l}12.72 \\
10.57 \\
13.37\end{array}$ & $\begin{array}{l}3.44 \\
0.19 \\
4.42\end{array}$ & $\begin{array}{l}0.54 \\
0.00 \\
0.70\end{array}$ & $\begin{array}{l}0.00 \\
0.00 \\
0.00\end{array}$ & $\begin{array}{l}0.00 \\
0.00 \\
0.00\end{array}$ & $\begin{array}{l}0.00 \\
0.00 \\
0.00\end{array}$ & $\begin{array}{l}0.00 \\
0.00 \\
0.00\end{array}$ & $\begin{array}{l}16.69 \\
10.76 \\
18.49\end{array}$ \\
\hline-12.70 & +9.53 & $-0.50+0.375$ & $\begin{array}{l}\text { Feed } \\
\text { Overs } \\
\text { Unders }\end{array}$ & $\begin{array}{l}7.01 \\
0.37 \\
9.01\end{array}$ & $\begin{array}{l}1.01 \\
0.02 \\
1.30\end{array}$ & $\begin{array}{l}0.00 \\
0.00 \\
0.00\end{array}$ & $\begin{array}{l}0.00 \\
0.00 \\
0.00\end{array}$ & $\begin{array}{l}0.00 \\
0.00 \\
0.00\end{array}$ & $\begin{array}{l}0.00 \\
0.00 \\
0.00\end{array}$ & $\begin{array}{l}0.00 \\
0.00 \\
0.00\end{array}$ & $\begin{array}{r}8.01 \\
0.39 \\
10.32\end{array}$ \\
\hline$-9.53+$ & +5.14 & $-0.375+0.202$ & $\begin{array}{l}\text { Feed } \\
\text { Overs } \\
\text { Unders }\end{array}$ & $\begin{array}{r}12.58 \\
0.20 \\
16.34\end{array}$ & $\begin{array}{l}1.97 \\
0.20 \\
2.50\end{array}$ & $\begin{array}{l}0.12 \\
0.00 \\
0.16\end{array}$ & $\begin{array}{l}0.00 \\
0.01 \\
0.00\end{array}$ & $\begin{array}{l}0.06 \\
0.00 \\
0.08\end{array}$ & $\begin{array}{l}0.14 \\
0.00 \\
0.18\end{array}$ & $\begin{array}{l}\mathbf{0 . 0 0} \\
\mathbf{0 . 0 0} \\
\mathbf{0 . 0 0}\end{array}$ & $\begin{array}{r}14.87 \\
0.41 \\
19.26\end{array}$ \\
\hline-5.14 & +2.74 & $-0.202+0.108$ & $\begin{array}{l}\text { Feed } \\
\text { Overs } \\
\text { Unders }\end{array}$ & $\begin{array}{l}7.11 \\
0.06 \\
9.24\end{array}$ & $\begin{array}{l}4.03 \\
0.00 \\
5.25\end{array}$ & $\begin{array}{l}0.00 \\
0.00 \\
0.00\end{array}$ & $\begin{array}{l}0.00 \\
0.00 \\
0.00\end{array}$ & $\begin{array}{l}0.34 \\
0.00 \\
0.44\end{array}$ & $\begin{array}{l}0.26 \\
0.00 \\
0.33\end{array}$ & $\begin{array}{l}0.00 \\
0.00 \\
0.00\end{array}$ & $\begin{array}{r}11.74 \\
0.06 \\
15.27\end{array}$ \\
\hline-2.74 & +1.30 & $-0.108+0.051$ & $\begin{array}{l}\text { Feed } \\
\text { Overs } \\
\text { Unders }\end{array}$ & $\begin{array}{l}5.16 \\
0.08 \\
6.70\end{array}$ & $\begin{array}{l}1.98 \\
0.00 \\
2.58\end{array}$ & $\begin{array}{l}0.00 \\
0.00 \\
0.00\end{array}$ & $\begin{array}{l}0.00 \\
0.00 \\
0.00\end{array}$ & $\begin{array}{l}2.96 \\
0.00 \\
3.85\end{array}$ & $\begin{array}{l}0.87 \\
0.00 \\
1.14\end{array}$ & $\begin{array}{l}0.00 \\
0.00 \\
0.00\end{array}$ & $\begin{array}{r}10.98 \\
0.08 \\
14.27\end{array}$ \\
\hline-1.30 & . & -0.051 & $\begin{array}{l}\text { Feed } \\
\text { Overs } \\
\text { Unders }\end{array}$ & $\begin{array}{l}0.00 \\
0.00 \\
0.00\end{array}$ & $\begin{array}{l}0.00 \\
0.00 \\
0.00\end{array}$ & $\begin{array}{l}0.00 \\
0.00 \\
0.00\end{array}$ & $\begin{array}{l}0.00 \\
0.00 \\
0.00\end{array}$ & $\begin{array}{l}0.00 \\
0.00 \\
0.00\end{array}$ & $\begin{array}{l}0.00 \\
0.00 \\
0.00\end{array}$ & $\begin{array}{r}15.57 \\
0.47 \\
20.14\end{array}$ & $\begin{array}{r}15.57 \\
0.47 \\
20.14\end{array}$ \\
\hline Total & & - & $\begin{array}{l}\text { Feed } \\
\text { Overs } \\
\text { Unders }\end{array}$ & $\begin{array}{l}63.29 \\
89.86 \\
55.24\end{array}$ & $\begin{array}{r}14.90 \\
5.54 \\
17.74\end{array}$ & $\begin{array}{l}1.61 \\
4.12 \\
0.86\end{array}$ & $\begin{array}{l}0.00 \\
0.01 \\
0.00\end{array}$ & $\begin{array}{l}3.36 \\
0.00 \\
4.37\end{array}$ & $\begin{array}{l}1.27 \\
0.00 \\
1.65\end{array}$ & $\begin{array}{r}15.57 \\
0.47 \\
20.14\end{array}$ & $\begin{array}{l}100.00 \\
100.00 \\
100.00\end{array}$ \\
\hline
\end{tabular}

* R ilesignales round sieve opconing. 
TABLE B-57. CCHPONENT/SIZE DISIRIBITION (12 rpm, feedrate $=4.91 \mathrm{Hg} / \mathrm{h}(\mathrm{s} .40$ tons/h), August 1981) ( $\%$ by weight)

\begin{tabular}{|c|c|c|c|c|c|c|c|c|c|c|}
\hline \multirow{2}{*}{\multicolumn{2}{|c|}{ Size class" }} & \multirow[b]{2}{*}{ Material } & \multirow[b]{2}{*}{$\begin{array}{l}\text { Paper \& } \\
\text { plastic }\end{array}$} & \multirow{2}{*}{$\begin{array}{l}\text { Organic } \\
\text { other }\end{array}$} & \multirow[b]{2}{*}{ Nonferrous } & \multirow[b]{2}{*}{ Ferrous } & \multirow[b]{2}{*}{ Glass } & \multirow[b]{2}{*}{$\begin{array}{c}\text { Inorganic } \\
\text { otlier }\end{array}$} & \multirow[b]{2}{*}{$\begin{array}{c}\text { Fines } \\
(-1.30 \mathrm{ma})\end{array}$} & \multirow[b]{2}{*}{ Total } \\
\hline & & & & & & & & & & \\
\hline+76.20 & +3 & $\begin{array}{l}\text { Feed } \\
\text { Overs } \\
\text { Unders }\end{array}$ & $\begin{array}{l}0.93 \\
3.76 \\
0.00\end{array}$ & $\begin{array}{l}0.69 \\
2.76 \\
0.00\end{array}$ & $\begin{array}{l}0.00 \\
0.00 \\
0.00\end{array}$ & $\begin{array}{l}0.00 \\
0.00 \\
0.00\end{array}$ & $\begin{array}{l}0.00 \\
0.00 \\
0.00\end{array}$ & $\begin{array}{l}0.00 \\
0.00 \\
0.00\end{array}$ & $\begin{array}{c}0.00 \\
0.00 \\
0.00 \\
0\end{array}$ & $\begin{array}{r}1.62 \\
6.52 \\
.0 .00\end{array}$ \\
\hline$-76.20+50.80$ & $-3+2$ & $\begin{array}{l}\text { Feed } \\
\text { Overs } \\
\text { Unders. }\end{array}$ & $\begin{array}{r}5: 97 \\
24.00 \\
0.00\end{array}$ & $\begin{array}{l}0.07 \\
0.30 \\
0.00\end{array}$ & $\begin{array}{l}0.00 \\
0.00 \\
0.00\end{array}$ & $\begin{array}{l}0.00 \\
0.00 \\
0.00\end{array}$ & $\begin{array}{l}0.00 \\
0.00 \\
0.00\end{array}$ & $\begin{array}{l}0.00 \\
0.00 \\
0.00\end{array}$ & $\begin{array}{l}0.00 \\
0.00 \\
0.00\end{array}$ & $\begin{array}{r}6.04 \\
24.30 \\
0.00\end{array}$ \\
\hline$-50.80+25.40$ & $-2 * 1$ & $\begin{array}{l}\text { Feed } \\
\text { Overs } \\
\text { Unders }\end{array}$ & $\begin{array}{r}11.56 \\
45.51 \\
0.00\end{array}$ & $\begin{array}{l}0.90 \\
3.54 \\
0.00\end{array}$ & $\begin{array}{l}0.14 \\
0.58 \\
0.00\end{array}$ & $\begin{array}{l}0.00 \\
0.00 \\
.0 .00\end{array}$ & $\begin{array}{l}0.00 \\
0.00 \\
0.00\end{array}$ & $\begin{array}{l}0.00 \\
0.00 \\
0.00\end{array}$ & $\begin{array}{l}0.00 \\
0.00 \\
0.00\end{array}$ & $\begin{array}{r}12.60 \\
49.63 \\
0.00\end{array}$ \\
\hline$-25.40+31.75 R$ & $-1+1.25 R$ & $\begin{array}{l}\text { Feed } \\
\text { Overs } \\
\text { Unders }\end{array}$ & $\begin{array}{l}0.21 \\
0.77 \\
0.33\end{array}$ & $\begin{array}{l}0.01 \\
0.05 \\
0.02\end{array}$ & $\begin{array}{l}0.00 \\
0.00 \\
0.00\end{array}$ & $\begin{array}{l}0.00 \\
0.00 \\
0.00\end{array}$ & $\begin{array}{l}0.00 \\
0.00 \\
0.00\end{array}$ & $\begin{array}{l}0.00 \\
0.00 \\
0.00\end{array}$ & $\begin{array}{l}0.00 \\
0.00 \\
0.00\end{array}$ & $\begin{array}{l}0.22 \\
0.82 \\
0.35\end{array}$ \\
\hline$-31.75 R+12.70$ & $-1.25 R+0.5 J$ & $\begin{array}{l}\text { Feed } \\
\text { Overs } \\
\text { Unders }\end{array}$ & $\begin{array}{l}15.38 \\
14.16 \\
15.78\end{array}$ & $\begin{array}{l}1.38 \\
0.53 \\
1.66\end{array}$ & $\begin{array}{l}0.20 \\
0.03 \\
0.26\end{array}$ & $\begin{array}{l}0.00 \\
0.00 \\
0.00\end{array}$ & $\begin{array}{l}0.00 \\
0.00 \\
0.00\end{array}$ & $\begin{array}{l}0.00 \\
0.00 \\
0.00\end{array}$ & $\begin{array}{l}0.00 \\
0.00 \\
0.00\end{array}$ & $\begin{array}{l}16.96 \\
14.69 \\
17.70\end{array}$ \\
\hline$-12.70+9.53$ & $-0.50+0.375$ & $\begin{array}{l}\text { Feed } \\
\text { Overs } \\
\text { Unders }\end{array}$ & $\begin{array}{r}7.93 \\
1.02 \\
10.22\end{array}$ & $\begin{array}{l}0.72 \\
0.06 \\
0.94\end{array}$ & $\begin{array}{l}0.13 \\
0.00 \\
0.18\end{array}$ & $\begin{array}{l}0.00 \\
0.00 \\
0.00\end{array}$ & $\begin{array}{l}0.00 \\
0.00 \\
0.00\end{array}$ & $\begin{array}{l}0.00 \\
0.00 \\
0.00\end{array}$ & $\begin{array}{l}0.00 \\
0.00 \\
0.00\end{array}$ & $\begin{array}{r}8.78 \\
1.08 \\
11.34\end{array}$ \\
\hline$-9.53+5.14$ & $-0.375+0.202$ & $\begin{array}{l}\text { Feed } \\
\text { Overs } \\
\text { Unders }\end{array}$ & $\begin{array}{r}14.31 \\
1.01 \\
18.71\end{array}$ & $\begin{array}{l}1.11 \\
0.19 \\
1.41\end{array}$ & $\begin{array}{l}0.01 \\
0.00 \\
0.01\end{array}$ & $\begin{array}{l}0.04 \\
0.00 \\
0.05\end{array}$ & $\begin{array}{l}0.04 \\
0.00 \\
0.05\end{array}$ & $\begin{array}{l}0.04 \\
0.00 \\
0.05\end{array}$ & $\begin{array}{l}0.00 \\
0.00 \\
0.00\end{array}$ & $\begin{array}{r}15.55 \\
1.20 \\
20.28\end{array}$ \\
\hline$-5.14+2.74$ & $-0.202+0.108$ & $\begin{array}{l}\text { Feed } \\
\text { Overs } \\
\text { Unders }\end{array}$ & $\begin{array}{l}6.63 \\
0.15 \\
8.78\end{array}$ & $\begin{array}{l}4.98 \\
0.16 \\
6.59\end{array}$ & $\begin{array}{l}0.01 \\
0.00 \\
0.01\end{array}$ & $\begin{array}{l}0.00 \\
0.00 \\
0.00\end{array}$ & $\begin{array}{l}0.27 \\
0.00 \\
0.36 \\
.\end{array}$ & $\begin{array}{l}-0.05 \\
0.00 \\
0.07\end{array}$ & $\begin{array}{l}0.00 \\
0.00 \\
0.00\end{array}$ & $\begin{array}{r}11.94 \\
0.31 \\
15.81\end{array}$ \\
\hline$-2.74+1.30$ & $-0.108+0.051$ & $\begin{array}{l}\text { Feed } \\
\text { Overs } \\
\text { Unders }\end{array}$ & $\begin{array}{l}5.57 \\
0.15 \\
737\end{array}$ & $\begin{array}{l}2.12 \\
0.11 \\
2.78\end{array}$ & $\begin{array}{l}0.00 \\
0.00 \\
0.00\end{array}$ & $\begin{array}{l}0.00 \\
0.00 \\
0.00\end{array}$ & $\begin{array}{r}2.08 \\
0.00 \\
-2.77\end{array}$ & $\begin{array}{l}0.61 \\
0.00 \\
0.82\end{array}$ & $\begin{array}{l}0.00 \\
0.00 \\
0.00\end{array}$ & $\begin{array}{r}10.38 \\
0.26 \\
13.74\end{array}$ \\
\hline-1.30 & $-0 .(5)$ & $\begin{array}{l}\text { Feed } \\
\text { Overs } \\
\text { Unders }\end{array}$ & $\begin{array}{ll}0 & 00 \\
0.00 \\
0.00\end{array}$ & $\begin{array}{l}0.00 \\
0.00 \\
0.00\end{array}$ & $\begin{array}{l}0.00 \\
0.00 \\
0.00\end{array}$ & $\begin{array}{l}0.00 \\
0.00 \\
0.00\end{array}$ & $\begin{array}{l}0.00 \\
0.00 \\
0.00\end{array}$ & $\begin{array}{l}0.00 \\
0.00 \\
0.00\end{array}$ & $\begin{array}{r}15.91 \\
1.19 \\
20.78\end{array}$ & $\begin{array}{r}15.91 \\
1.19 \\
20.78\end{array}$ \\
\hline Total & - & $\begin{array}{l}\text { Feed } \\
\text { Overs } \\
\text { Unders }\end{array}$ & $\begin{array}{l}68.49 \\
90.53 \\
61.19\end{array}$ & $\begin{array}{r}11.98 \\
7.70 \\
13.40\end{array}$ & $\begin{array}{l}0.49 \\
0.58 \\
0.46\end{array}$ & $\begin{array}{l}0.04 \\
0.00 \\
0.05\end{array}$ & $\begin{array}{l}2.39 \\
0.00 \\
3.18\end{array}$ & $\begin{array}{l}0.70 \\
0.00 \\
0.94\end{array}$ & $\begin{array}{r}15.91 \\
1.19 \\
20.78\end{array}$ & $\begin{array}{l}100.00 \\
100.00 \\
100.00\end{array}$ \\
\hline
\end{tabular}

$\div \quad$ designates round siEve opening. 
TABIE B-5B. COMPONENT/SIZE DISTRIBUTION (12 rpm, feedrate $=7.12 \mathrm{Mg} / \mathrm{h}(7.83$ cons/h), August 1981) ( $\%$ by weight)

\begin{tabular}{|c|c|c|c|c|c|c|c|c|c|c|c|}
\hline & \multicolumn{2}{|c|}{ Size class * } & Material & $\begin{array}{l}\text { Paper \& } \\
\text { plastic }\end{array}$ & $\begin{array}{c}\text { Organic } \\
\text { other }\end{array}$ & Nonferrous & Ferrolis & Glass & $\begin{array}{c}\text { Inorganic } \\
\text { other }\end{array}$ & $\begin{array}{c}\text { Fines } \\
(-1.30 \mathrm{~mm})\end{array}$ & Total \\
\hline+76.20 & & +3 & $\begin{array}{l}\text { Feed } \\
\text { Overs } \\
\text { Unders }\end{array}$ & $\begin{array}{l}2.36 \\
7.93 \\
0.00\end{array}$ & $\begin{array}{l}0.00 \\
0.00 \\
0.00\end{array}$ & $\begin{array}{l}0.00 \\
0.00 \\
0.00\end{array}$ & $\begin{array}{l}0.00 \\
0.00 \\
0.00\end{array}$ & $\begin{array}{l}0.00 \\
0.00 \\
0.00\end{array}$ & $\begin{array}{l}0.00 \\
0.00 \\
0.00\end{array}$ & $\begin{array}{l}0.00 \\
0.00 \\
0.00\end{array}$ & $\begin{array}{l}2.36 \\
7.93 \\
0.00\end{array}$ \\
\hline-76.20 & +50.80 & $-3+2$ & $\begin{array}{l}\text { Feed } \\
\text { Overs } \\
\text { Unders }\end{array}$ & $\begin{array}{r}7.92 \\
26.59 \\
0.00\end{array}$ & $\begin{array}{l}0.10 \\
0.33 \\
0.00\end{array}$ & $\begin{array}{l}0.22 \\
0.72 \\
0.00\end{array}$ & $\begin{array}{l}0.05 \\
0.17 \\
0.00\end{array}$ & $\begin{array}{l}0.00 \\
0.00 \\
0.00\end{array}$ & $\begin{array}{l}0.00 \\
0.00 \\
0.00\end{array}$ & $\begin{array}{l}0.00 \\
0.00 \\
0.00\end{array}$ & $\begin{array}{r}8.29 \\
27.81 \\
0.00\end{array}$ \\
\hline-50.80 & +25.40 & $-2+1$ & $\begin{array}{l}\text { Feed } \\
\text { Overs } \\
\text { Unders }\end{array}$ & $\begin{array}{r}10.81 \\
35.80 \\
0.00\end{array}$ & $\begin{array}{l}0.12 \\
0.39 \\
0.00\end{array}$ & $\begin{array}{l}0.41 \\
1.36 \\
0.00\end{array}$ & $\begin{array}{l}0.14 \\
0.49 \\
0.00\end{array}$ & $\begin{array}{l}0.00 \\
0.00 \\
0.00\end{array}$ & $\begin{array}{l}0.00 \\
0.00 \\
0.00\end{array}$ & $\begin{array}{l}0.00 \\
0.00 \\
0.00\end{array}$ & $\begin{array}{r}11.48 \\
38.04 \\
0.00\end{array}$ \\
\hline-25.40 & $+31.75 R$ & $-1+1.25 R$ & $\begin{array}{l}\text { Feed } \\
\text { Overs } \\
\text { Unders }\end{array}$ & $\begin{array}{l}0.96 \\
2.86 \\
0.38\end{array}$ & $\begin{array}{l}0.02 \\
0.06 \\
0.00\end{array}$ & $\begin{array}{l}0.00 \\
0.00 \\
0.00\end{array}$ & $\begin{array}{l}0.00 \\
0.00 \\
0.00\end{array}$ & $\begin{array}{l}0.00 \\
0.00 \\
0.00\end{array}$ & $\begin{array}{l}0.00 \\
0.00 \\
0.00\end{array}$ & $\begin{array}{l}0.00 \\
0.00 \\
0.00\end{array}$ & $\begin{array}{l}0.98 \\
2.92 \\
0.38\end{array}$ \\
\hline$-31.75 f$ & $R+12.70$ & $-1.25 R+0.50$ & $\begin{array}{l}\text { Feed } \\
\text { Overs } \\
\text { Unders }\end{array}$ & $\begin{array}{l}11.97 \\
14.53 \\
10.89\end{array}$ & $\begin{array}{l}0.78 \\
0.42 \\
0.93\end{array}$ & $\begin{array}{l}0.17 \\
0.12 \\
0.18\end{array}$ & $\begin{array}{l}0.00 \\
0.00 \\
0.00\end{array}$ & $\begin{array}{l}0.00 \\
0.00 \\
0.00\end{array}$ & $\begin{array}{l}0.00 \\
0.00 \\
0.00\end{array}$ & $\begin{array}{l}0.00 \\
0.00 \\
0.00\end{array}$ & $\begin{array}{l}12.92 \\
15.07 \\
12.00\end{array}$ \\
\hline-12.70 & +9.53 & $-0.50+0.375$ & $\begin{array}{l}\text { Feed } \\
\text { Overs } \\
\text { Unders }\end{array}$ & $\begin{array}{l}6.74 \\
1.57 \\
8.94\end{array}$ & $\begin{array}{l}0.25 \\
0.13 \\
0.30\end{array}$ & $\begin{array}{l}0.14 \\
0.04 \\
0.18\end{array}$ & $\begin{array}{l}0.00 \\
0.00 \\
0.00\end{array}$ & $\begin{array}{l}0.00 \\
0.00 \\
0.00\end{array}$ & $\begin{array}{l}0.00 \\
0.00 \\
0.00\end{array}$ & $\begin{array}{l}0.00 \\
0.00 \\
0.00\end{array}$ & $\begin{array}{l}7.13 \\
1.74 \\
9.42\end{array}$ \\
\hline$-9.53 \cdot$ & +5.14 & $-0.375+0.202$ & $\begin{array}{l}\text { Feed } \\
\text { Overs } \\
\text { Unders }\end{array}$ & $\begin{array}{r}11.76 \\
2.24 \\
15.80\end{array}$ & $\begin{array}{l}0.43 \\
0.36 \\
0.46\end{array}$ & $\begin{array}{l}0.03 \\
0.00 \\
0.05\end{array}$ & $\begin{array}{l}0.39 \\
0.00 \\
0.56\end{array}$ & $\begin{array}{l}0.18 \\
0.00 \\
0.25\end{array}$ & $\begin{array}{l}0.25 \\
0.00 \\
0.36\end{array}$ & $\begin{array}{l}0.00 \\
0.00 \\
0.00\end{array}$ & $\begin{array}{r}13.04 \\
2.60 \\
17.48\end{array}$ \\
\hline-5.14 & +2.74 & $-0.202+0.108$ & $\begin{array}{l}\text { Feed } \\
\text { Overs } \\
\text { Unders }\end{array}$ & $\begin{array}{r}8.26 \\
0.26 \\
11.45\end{array}$ & $\begin{array}{l}2.25 \\
0.23 \\
3.11\end{array}$ & $\begin{array}{l}0.00 \\
0.00 \\
0.00\end{array}$ & $\begin{array}{l}0.00 \\
0.00 \\
0.00\end{array}$ & $\begin{array}{l}1.31 \\
0.01 \\
1.86\end{array}$ & $\begin{array}{l}1.33 \\
0.01 \\
1.88\end{array}$ & $\begin{array}{l}0.00 \\
0.00 \\
0.00\end{array}$ & $\begin{array}{r}13.15 \\
1.01 \\
18.30\end{array}$ \\
\hline-2.74 & +1.30 & $-0.108+0.051$ & $\begin{array}{l}\text { Feed } \\
\text { Overs } \\
\text { Unders }\end{array}$ & $\begin{array}{l}5.37 \\
0.41 \\
7.48\end{array}$ & $\begin{array}{l}1.95 \\
0.41 \\
2.60\end{array}$ & $\begin{array}{l}0.00 \\
0.00 \\
0.00\end{array}$ & $\begin{array}{l}0.00 \\
0.00 \\
0.00\end{array}$ & $\begin{array}{l}4.91 \\
0.04 \\
6.97\end{array}$ & $\begin{array}{l}0.87 \\
0.57 \\
0.99\end{array}$ & $\begin{array}{l}0.00 \\
0.00 \\
0.00\end{array}$ & $\begin{array}{r}13.10 \\
1.43 \\
18.04\end{array}$ \\
\hline-1.30 & . & -0.051 & $\begin{array}{l}\text { Feed } \\
\text { Overs } \\
\text { Unders }\end{array}$ & $\begin{array}{l}0.00 \\
0.00 \\
0.00\end{array}$ & $\begin{array}{l}0.00 \\
0.00 \\
0.00\end{array}$ & $\begin{array}{l}0.00 \\
0.00 \\
0.00\end{array}$ & $\begin{array}{l}0.00 \\
0.00 \\
0.00\end{array}$ & $\begin{array}{l}0.00 \\
0.00 \\
0.00\end{array}$ & $\begin{array}{r}0.00 \\
0.00 \\
0.00\end{array}$ & $\begin{array}{r}17.55 \\
1.45 \\
24.38\end{array}$ & $\begin{array}{r}17.55 \\
1.45 \\
24.38\end{array}$ \\
\hline Total & & - & $\begin{array}{l}\text { Feed } \\
\text { Overs } \\
\text { Unders }\end{array}$ & $\begin{array}{l}66.15 \\
92.69 \\
54.94\end{array}$ & $\begin{array}{l}5.90 \\
2.33 \\
7.40\end{array}$ & $\begin{array}{l}0.97 \\
2.24 \\
0.41\end{array}$ & $\begin{array}{r}0.58 \\
0: 66 \\
0.56\end{array}$ & $\begin{array}{l}6.40 \\
0.05 \\
9.08\end{array}$ & $\begin{array}{l}2.45 \\
0.58 \\
3.23\end{array}$ & $\begin{array}{r}17.55 \\
1.45 \\
24.38\end{array}$ & $\begin{array}{l}100.00 \\
100.00 \\
100.00\end{array}$ \\
\hline
\end{tabular}

* R designates round sieve opening. 
TABLE B-55, CCMPONENT/SIZE DIS'CKIBUTION (12 $\mathrm{rpm}$, feedrate $=13.79 \mathrm{Hg} / \mathrm{h} / 15.17$ (ons/h), August 1981) (\% hy we: ght)

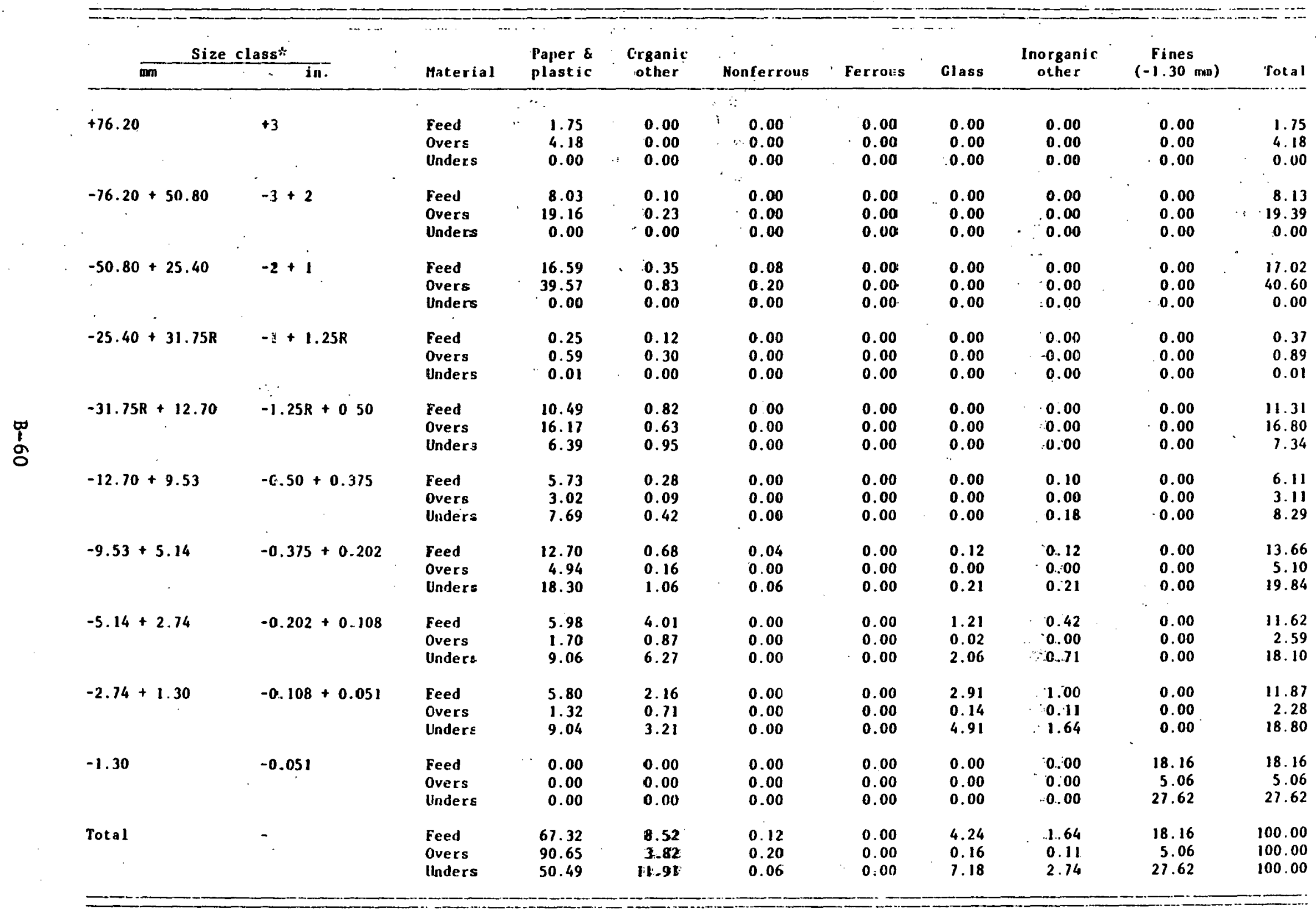

$\therefore \quad R$ designales round sieve opening. 
TABIE B-60. COMPGNENT/SIZE DISTRIBUTION $(12 \mathrm{rpm}$, feedrate $=32.06 \mathrm{Hg} / \mathrm{h}(35.27$ tons/h), August 1981) (\% by weight)

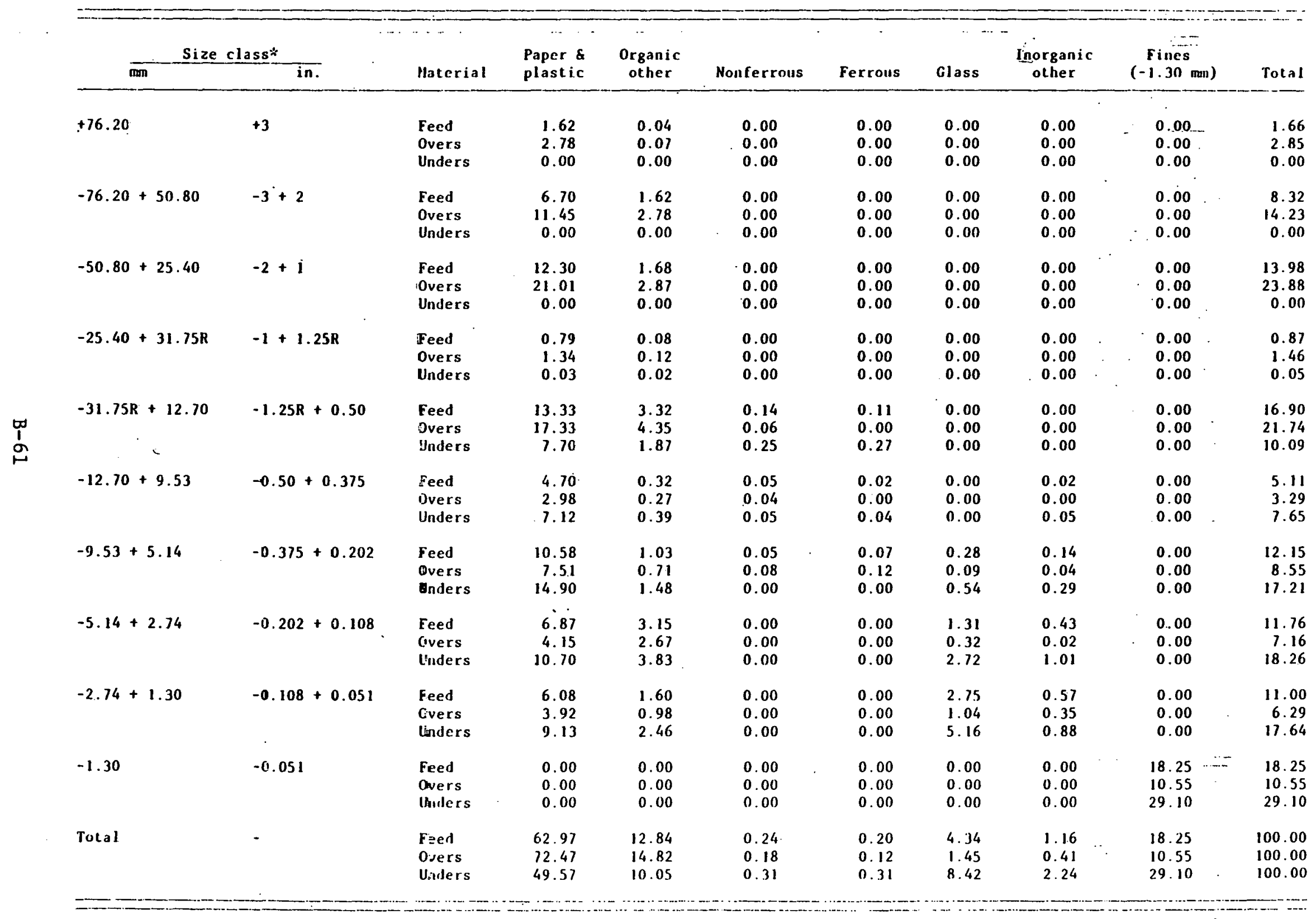

$\therefore$ R designates round sieve opening. 
APPENDIX C

TROMMEL PERFORMANCE TEST DATA

C-1 
Test period

Table title

October 1980

October 1980

October 1980

October 1980

January 1981

January 1981

January 1981

January 1981

May 1981

May 1981

May 1981

May 1981

August 1981

August 1981

August 1981

August 1981
Trommel performance characterization - October 1980

Properties of feed material - October 1980

Properties of oversize fraction - October 1980

Properties of undersize fraction - October 1980

Trommel performance characterization - January 1981

Properties of feed material - January 1981

Properties of oversize fraction - January 1981

Properties of undersize fraction - Tanuary 1981

Trommel performance characterization - May 1981

Properties of feed material - May 1981

Properties of oversize fraction - May 1981

Properties of undersize fraction - May 1981

Trommel performance characterization - August 1981

Properties of feed material - August 1981

Properties of oversize fraction - August 1981

Properties of undersize fraction - August 198 
TABLE C-2. TROMMEL PERFORMANCE CHARACTERIZATION - OCTOBER 1980

Rotational speed

$6 \mathrm{rpm}$

\begin{tabular}{|c|c|c|c|c|c|}
\hline & \multicolumn{5}{|c|}{ Rotational speed } \\
\hline & \multicolumn{5}{|c|}{$6 \mathrm{rpm}$} \\
\hline Feedrate $(\mathrm{Mg} / \mathrm{h})$ & 1.76 & 3.13 & 4.74 & 12.84 & 23.91 \\
\hline Screening efficiency (\%) & 90.3 & 92.8 & $90.8^{\circ}$ & 69.5 & 32.3 \\
\hline Oversize split $(\%)$ & 36.08 & 49.31 & 29.39 & 47.40 & 76.09 \\
\hline Undersize split (\%) & 63.92 & 50.69 & 70.61 & 52.60 & 23.91 \\
\hline Oversize flow rate $(\mathrm{Mg} / \mathrm{h})$ & 0.64 & 1.55 & 1.39 & 6.09 & 18.18 \\
\hline Undersize flow rate (Mgih) & 1.12 & 1.58 & 3.35 & 6.75 & 5.73 \\
\hline True undersize in oversize fraction $(\%)$ & 18.9 & 21.3 & 24.2 & 48.7 & 65.9 \\
\hline Heating value improvement (\%) & 132.8 & 122.1 & 123.7 & 134.6 & 101.5 \\
\hline Energy recovery $(\%)$ & 47.9 & 60.2 & 36.4 & 63.8 & 77.3 \\
\hline Ash/energy content of oversize & & & & & $\therefore$ \\
\hline fraction $(\mathrm{kg} / \mathrm{GJ})$ & 2.16 & 4.33 & 6.05 & 2.76 & 5.26 \\
\hline Organic quality improvement (\%) & 140.5 & 124.1 & 121.5 & 135.9 & 110.3 \\
\hline Organic recovery $(\%)$ & 50.9 & 61.3 & 35.7 & 64.5 & 83.9 \\
\hline Ash content removal (\%) & 80.2 & 56.5 & 43.8 & 81.3 & 34.9 \\
\hline Moisture content remova $(\%)$ & 41.6 & 30.5 & 44.3 & 8.9 & 0.3 \\
\hline Sample time (sec) & 78 & 83 & 48 & 40 & 45 \\
\hline Leading edge residence time (sec) & 85 & 89 & 105 & 80 & 68 \\
\hline Tracer residence time (sec) & 45 & 41 & 66 & 63 & 51 \\
\hline Motor power requirement $(\mathrm{kW})$ & 5.37 & 2.31 & 3.51 & 4.30 & 5.31 \\
\hline Specific motor power requirements & & & & & \\
\hline$(\mathrm{kWh} / \mathrm{Mg})$ & 3.05 & 0.75 & 0.75 & 0.34 & 0.22 \\
\hline
\end{tabular}


TABLE C-2. (continued)

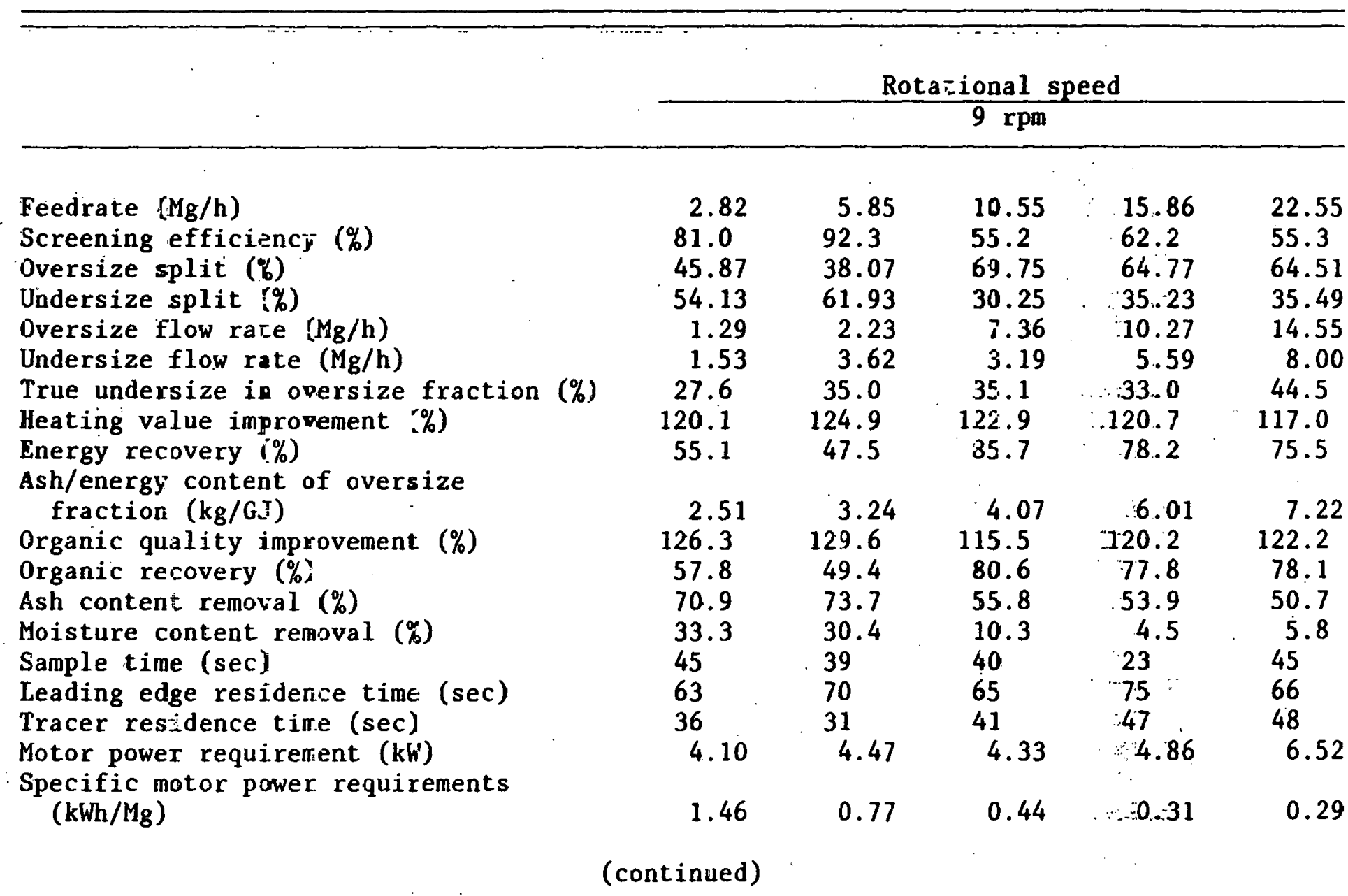




\begin{tabular}{|c|c|c|c|c|c|}
\hline \multirow{11}{*}{$\begin{array}{l}\text { Feedrate }(\mathrm{Mg} / \mathrm{h}) \\
\text { Screening efficiency }(\%) \\
\text { Oversize split }(\%) \\
\text { Undersize split }(\%) \\
\text { Oversize flow rate }(\mathrm{Mg} / \mathrm{h}) \\
\text { Undersize flow rate }(\mathrm{Mg} / \mathrm{h}) \\
\text { True undersize in oversize fraction }(\%) \\
\text { Heating value improvement }(\%) \\
\text { Energy recovery }(\%)\end{array}$} & \multicolumn{5}{|c|}{ Rotational speed } \\
\hline & \multicolumn{5}{|c|}{$12 \mathrm{rpm}$} \\
\hline & 3.43 & 9.11 & 13.62 & 30.27 & 38.52 \\
\hline & 92.6 & 68.2 & 75.5 & 50.1 & 43.7 \\
\hline & 35.48 & 63.70 & 44.49 & 68.53 & 68.73 \\
\hline & 64.52 & 36.30 & 55.51 & 31.47 & 31.27 \\
\hline & 1.22 & 5.80 & 6.06 & 20.74 & 26.47 \\
\hline & 2.21 & 3.31 & 7.56 & 9.53 & 12.05 \\
\hline & 14.6 & 22.6 & 40.5 & 45.6 & 58.5 \\
\hline & 143.2 & 124.5 & 117.1 & 113.7 & 110.0 \\
\hline & 50.8 & 79.3 & 52.1 & 77.9 & 76.3 \\
\hline \multirow{12}{*}{$\begin{array}{l}\text { Ash/energy content of oversize } \\
\text { fraction (kg/GJ) } \\
\text { Organic quality improventent (\%) } \\
\text { Organic recovery }(\%) \\
\text { Ash content removal (\%) } \\
\text { Moisture content removal (\%) } \\
\text { Sample time (sec) } \\
\text { Leading edge residence time (sec) } \\
\text { Tracer residence time (sec) } \\
\text { Motor power requirement (kW) } \\
\text { Specific motor power requirements } \\
\quad(\mathrm{kWh} / \mathrm{Mg})\end{array}$} & & & & & \\
\hline & 1.81 & 3.73 & 3.81 & 6.36 & 7.59 \\
\hline & 174.2 & 121.6 & 127.4 & 118.9 & 116.6 \\
\hline & 61.9 & 77.4 & 56.7 & 81.5 & 80.1 \\
\hline & 89.0 & 62.7 & 64.0 & 43.4 & 37.0 \\
\hline & 18.3 & 10.7 & 6.9 & 6.3 & 2.6 \\
\hline & 52 & 23 & 24 & 23 & 28 \\
\hline & 58 & 54 & 89 & 62 & 62 \\
\hline & 26 & 43 & 28 & 50 & 40 \\
\hline & 4.42 & 4.23 & - & 5.23 & 6.71 \\
\hline & & & & & \\
\hline & 1.30 & 0.46 & - & 0.17 & 0.17 \\
\hline
\end{tabular}


TABLE C-3. PROPERTIES OF FEED MATERIAL - JCTCBER 1980

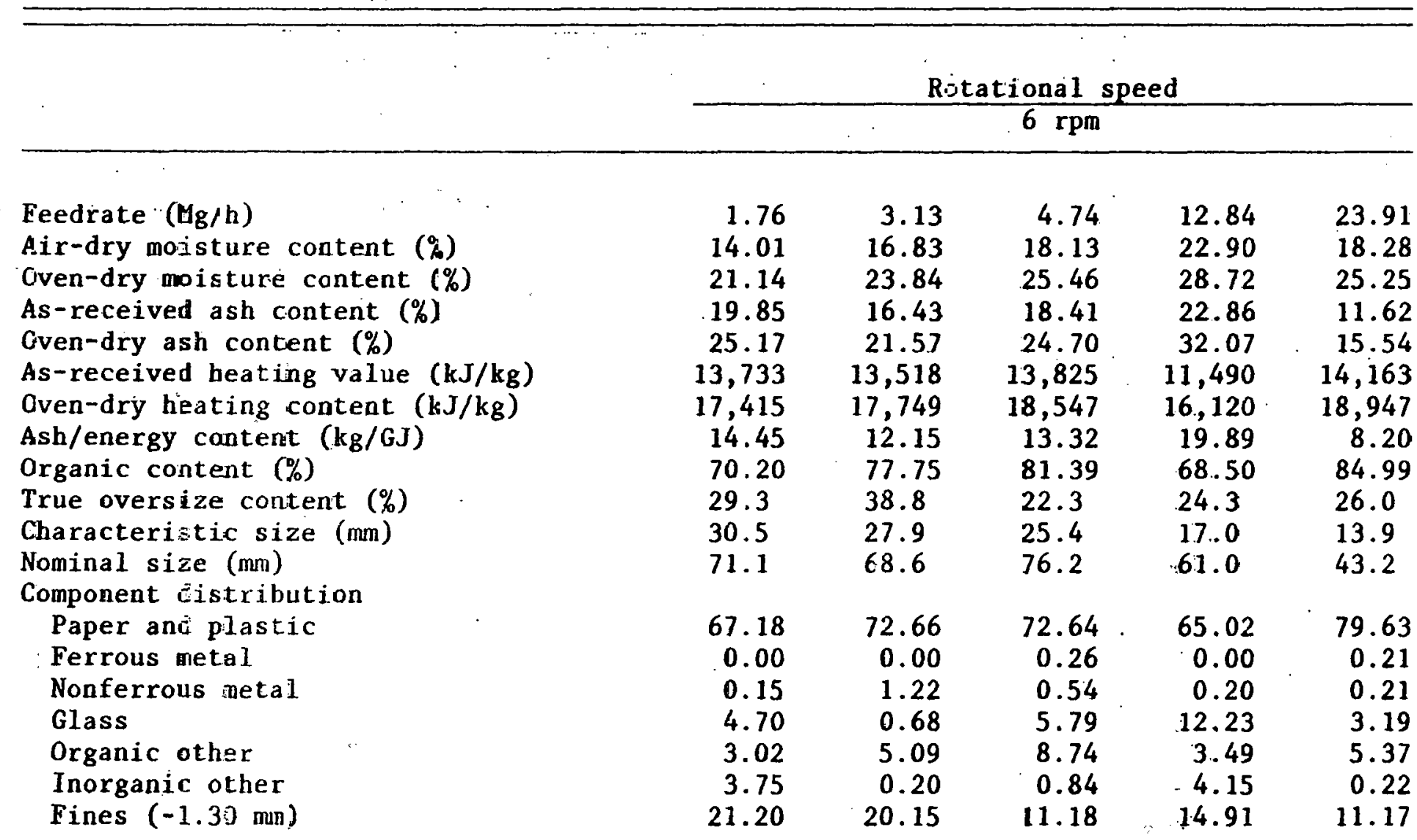

(continued) 
TABLE C-3. (continued)

\begin{tabular}{|c|c|c|c|c|c|}
\hline & \multicolumn{5}{|c|}{ Rotational speed } \\
\hline & \multicolumn{5}{|c|}{$9 \mathrm{rpm}$} \\
\hline Feedrate $(\mathrm{Mg} / \mathrm{h})$ & 2.82 & 5.85 & 10.55 & 15.86 & 22.55 \\
\hline Air-dry moisture content $(\%)$ & 13.39 & 15.03 & 18.69 & 19.63 & 14.56 \\
\hline Oven-dry moisture content $(\%)$ & 20.53 & 21.79 & 25.14 & 26.03 & 21.12 \\
\hline As-received ash content $(\%)$ & 15.45 & 21.37 & 15.79 & 19.25 & 22.24 \\
\hline Oven-dry ash content $(\%)$ & 19.44 & 27.33 & 21.09 & 26.03 & 28.19 \\
\hline As-received heating value $(\mathrm{kJ} / \mathrm{kg})$ & 14,886 & 13,942 & 13,940 & $12,2.23$ & 12,980 \\
\hline Oven-iry heating content $(\mathrm{kJ} / \mathrm{kg})$ & 18,732 & 17,827 & 18,622 & 16,524 & 16,456 \\
\hline Ash/energy content ( $\mathrm{kg} / \mathrm{GJ})$ & 10.38 & 15.33 & 11.33 & 15.75 & 17.13 \\
\hline Organic content $(\%)$ & 78.15 & 75.72 & 83.09 & 78.11 & 76.22 \\
\hline True oversize content $(\%)$ & 33.2 & 24.8 & 45.2 & 43.4 & 35.8 \\
\hline Characteristic size (mm) & 19.9 & 23.4 & 19.4 & 20. 7 & 16.5 \\
\hline Nominal size $(\mathrm{mm})$ & 73.7 & 63.5 & 76.2 & $66 \ldots$ & 66.0 \\
\hline \multicolumn{6}{|l|}{ Component distribution } \\
\hline Paper and plastic & 73.48 & 70.78 & 78.02 & $74 \ldots 23$ & 73.38 \\
\hline Ferrous metal & 0.07 & 0.13 & 0.00 & 0.13 & 0.00 \\
\hline Nonferrous metal & 0.11 & 0.01 & 0.04 & 0.06 & 0.03 \\
\hline Glass & 3.87 & 10.82 & 3.39 & $.5 . .93$ & 9.94 \\
\hline Organic other & 4.67 & 4.93 & 5.06 & 3.88 & 2.83 \\
\hline Inorganic other & 0.55 & 2.71 & 0.77 & 2.68 & 0.35 \\
\hline Fines $(-1.30 \mathrm{~mm})$ & 17.25 & 10.62 & 12.72 & .13 .09 & 13.47 \\
\hline
\end{tabular}

(continued) 
TABLE C-3. (continued)

\begin{tabular}{|c|c|c|c|c|c|}
\hline \multirow[b]{2}{*}{-} & \multicolumn{5}{|c|}{ Rotational speed } \\
\hline & & & $12 \mathrm{rpm}$ & & \\
\hline $\begin{array}{l}\text { Feedrate }(\mathrm{Mg} / \mathrm{h}) \\
\text { Air-dry moisture content }(\%) \\
\text { Oven-dry noisture content }(\%) \\
\text { As-received ash content }(\%) \\
\text { Oven-dry ash content }(\%) \\
\text { As-received heating value }(\mathrm{kJ} / \mathrm{kg}) \\
\text { Oven-dry beating content }(\mathrm{kJ} / \mathrm{kg}) \\
\text { Ash/energy content }(\mathrm{kg} / \mathrm{GJ}) \\
\text { Organic content }(\%) \\
\text { True oversize content }(\%) \\
\text { Characteristic size (mm) } \\
\text { Nominal size (mm) } \\
\text { Component distribution } \\
\text { Paper and plastic } \\
\text { Ferrous metal } \\
\text { Nonferrous metal } \\
\text { Glass } \\
\text { Organic other } \\
\text { Inorganic cther } \\
\text { Fines ( }-1.30 \mathrm{~mm})\end{array}$ & $\begin{array}{r}3.43 \\
18.69 \\
23.48 \\
31.60 \\
41.29 \\
13,458 \\
17,587 \\
23.48 \\
56.77 \\
30.3 \\
33.0 \\
81.3\end{array}$ & $\begin{array}{r}19.11 \\
19.67 \\
25.90 \\
15.62 \\
21.08 \\
12,524 \\
16,902 \\
12.47 \\
80.57 \\
49.3 \\
23.8 \\
63.6 \\
\vdots \\
\therefore \quad 78.49 \\
0.00 \\
0.03 \\
\quad 4.92 \\
2.08 \\
1.35 \\
13.13\end{array}$ & $\begin{array}{c}13.62 \\
21.65 \\
28.15 \\
16.26 \\
22.63 \\
13,124 \\
18,266 \\
12.39 \\
76.27 \\
18.0 \\
18.6 \\
53.3\end{array}$ & $\begin{array}{c}30.27 \\
24.30 \\
30.12 \\
16.72 \\
23.92 \\
13,098 \\
18,743 \\
12.76 \\
76.90 \\
37.3 \\
16.6 \\
63.5\end{array}$ & $\begin{array}{r}38.52 \\
27.14 \\
33.11 \\
15.93 \\
23.82 \\
11,912 \\
17,809 \\
13.28 \\
78.17 \\
28.5 \\
14.4 \\
48.3\end{array}$ \\
\hline
\end{tabular}


Rotational speed

$6 \mathrm{rpm}$

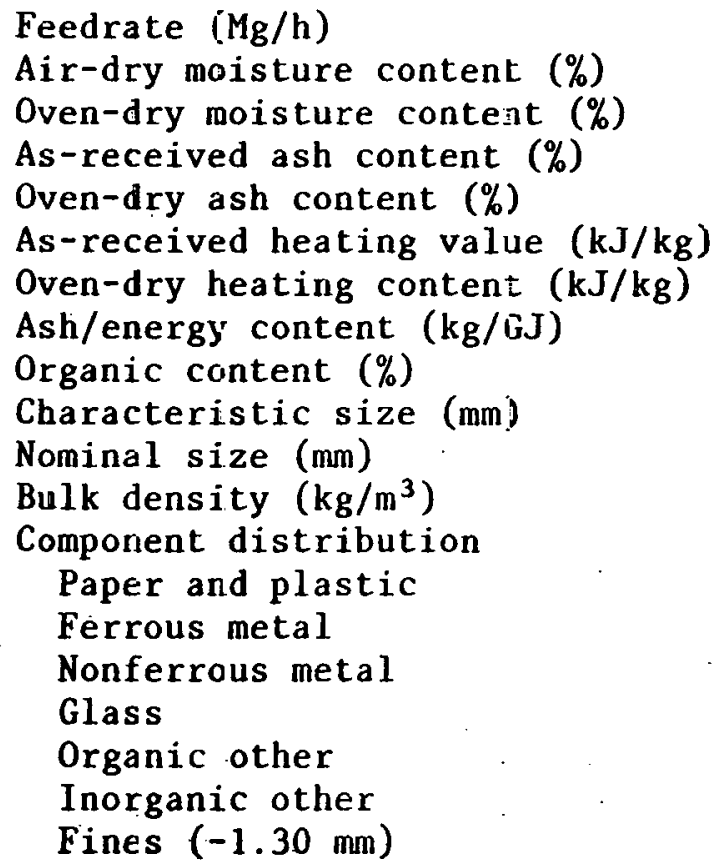

$\begin{array}{rrrrr}1.76 & 3.13 & 4.74 & 12.84 & 23.91 \\ 2.91 & 8.43 & 6.87 & 19.42 & 18.26 \\ 12.35 & 16.56 & 14.19 & 26.17 & 25.18 \\ 3.94 & 7.15 & 10.35 & 4.27 & 7.56 \\ 4.50 & 8.57 & 12.06 & 5.78 & 10.10 \\ 18,240 & 16,500 & 17,104 & 15,469 & 14,380 \\ 20,810 & 19.775 & 19,932 & 20,952 & 19,219 \\ 2.16 & 4.33 & 6.05 & 2.76 & 5.26 \\ 98.59 & 96.45 & 98.88 & 93.12 & 93.72 \\ 58.42 & 53.34 & 56.39 & 38.10 & 22.86 \\ 78.74 & 83.82 & 88.90 & 76.20 & 76.20 \\ 27.23 & 35.24 & 26.63 & 65.67 & 67.28 \\ & & & & \\ 96.63 & 93.50 & 98.89 & 88.75 & 87.59 \\ 0.00 & 0.00 & 0.00 & 0.00 & 0.00 \\ 0.00 & 2.04 & 0.00 & 0.00 & 0.19 \\ 0.00 & 0.00 & 0.03 & 0.32 & 1.94 \\ 1.96 & 2.95 & 5.00 & 4.38 & 6.14 \\ 0.00 & 0.00 & 0.03 & 0.14 & 0.10 \\ 1.41 & 1.51 & 1.05 & .6 .41 & 4.04\end{array}$

(continued) 
TABLE C-4. (continued)

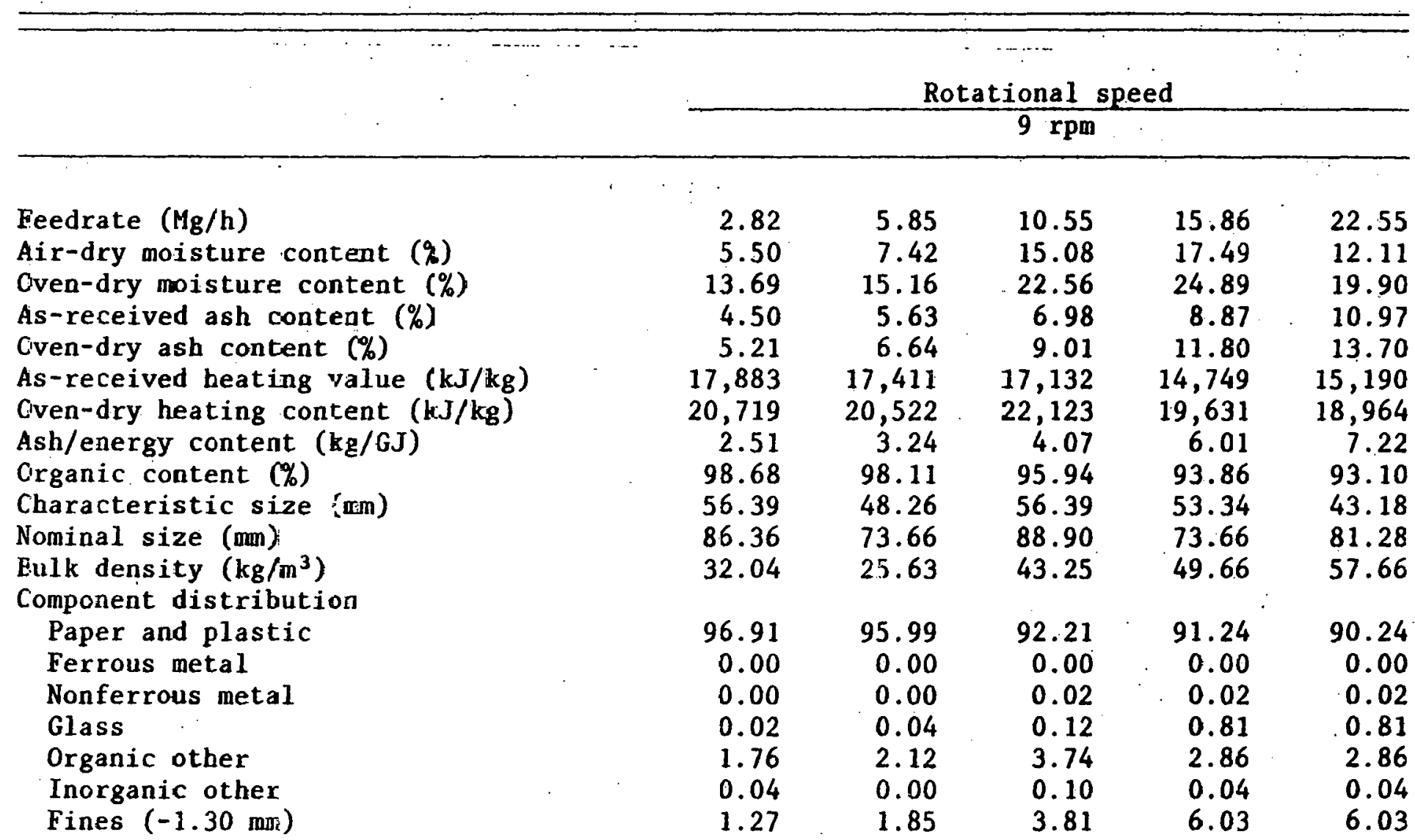

(continued) 


\begin{tabular}{|c|c|c|c|c|c|}
\hline & \multicolumn{5}{|c|}{ Rotational speed } \\
\hline & \multicolumn{5}{|c|}{$12 \mathrm{rpm}$} \\
\hline Feedrate $(\mathrm{Mg} / \mathrm{h})$ & 3.43 & 9.11 & 13.62 & 30.27 & 38.52 \\
\hline Air-dry moisture content $(\%)$ & 12.52 & 16.27 & 19.00 & 22.01 & 25.69 \\
\hline Oven-dry moisture content (\%) & 19.18 & 23.14 & 26.21 & 28.22 & 32.29 \\
\hline As-received ash content $(\%)$ & 3.49 & 5.82 & 5.85 & 9.47 & 10.04 \\
\hline Oven-dry ash content $(\%)$ & 4.32 & 7.57 & 7.93 & 13.20 & 14.82 \\
\hline As-received heating value $(\mathrm{kJ} / \mathrm{kg})$ & 19,273 & 15,590 & 15,373 & 14,889 & 13,228 \\
\hline Oven-dry heating content $(\mathrm{kJ} / \mathrm{kg})$ & 23,847 & 20,284 & 20,834 & 20.743 & 19,527 \\
\hline Ash/energy content $(\mathrm{kg} / \mathrm{GJ})$ & 1.81 & 3.73 & 3.81 & 6.36 & 7.59 \\
\hline Organic content $(\%)$ & 98.88 & 97.99 & 97.19 & 91.41 & 91.12 \\
\hline Characteristic size $(\mathrm{mm})$ & 66.04 & 50.80 & 38.10 & 40.64 & 25.40 \\
\hline Nominal size $(\mathrm{mm})$ & 91.44 & 82.82 & 68.58 & 81.28 & 66.04 \\
\hline Bulk density $\left(\mathrm{kg} / \mathrm{m}^{3}\right)$ & 33.64 & 51.26 & 46.45 & 60.87 & 60.87 \\
\hline Component distribution & & & & & \\
\hline Paper and plastic & 97.53 & 96.84 & 93.54 & 88.52 & 83.73 \\
\hline Ferrous netal & 0.00 & 0.00 & 0.00 & 0.38 & 0.00 \\
\hline Nonferrous metal & 0.00 & 0.00 & 0.00 & 0.09 & 0.83 \\
\hline Glass & 0.01 & 0.08 & 0.06 & 0.34 & 0.59 \\
\hline Organic other & 1.37 & 1.16 & 3.66 & 2.89 & 7.39 \\
\hline Inorganic other & 0.05 & 0.09 & 0.07 & 0.07 & 0.10 \\
\hline Fines $(-1.30 \mathrm{~mm})$ & 1.04 & 1.83 & 2.67 & 7.71 & 7.36 \\
\hline
\end{tabular}


TABIE C -5 . PROPERTIES OF UNDERSIZE FRACTION - OCTOBER 1980

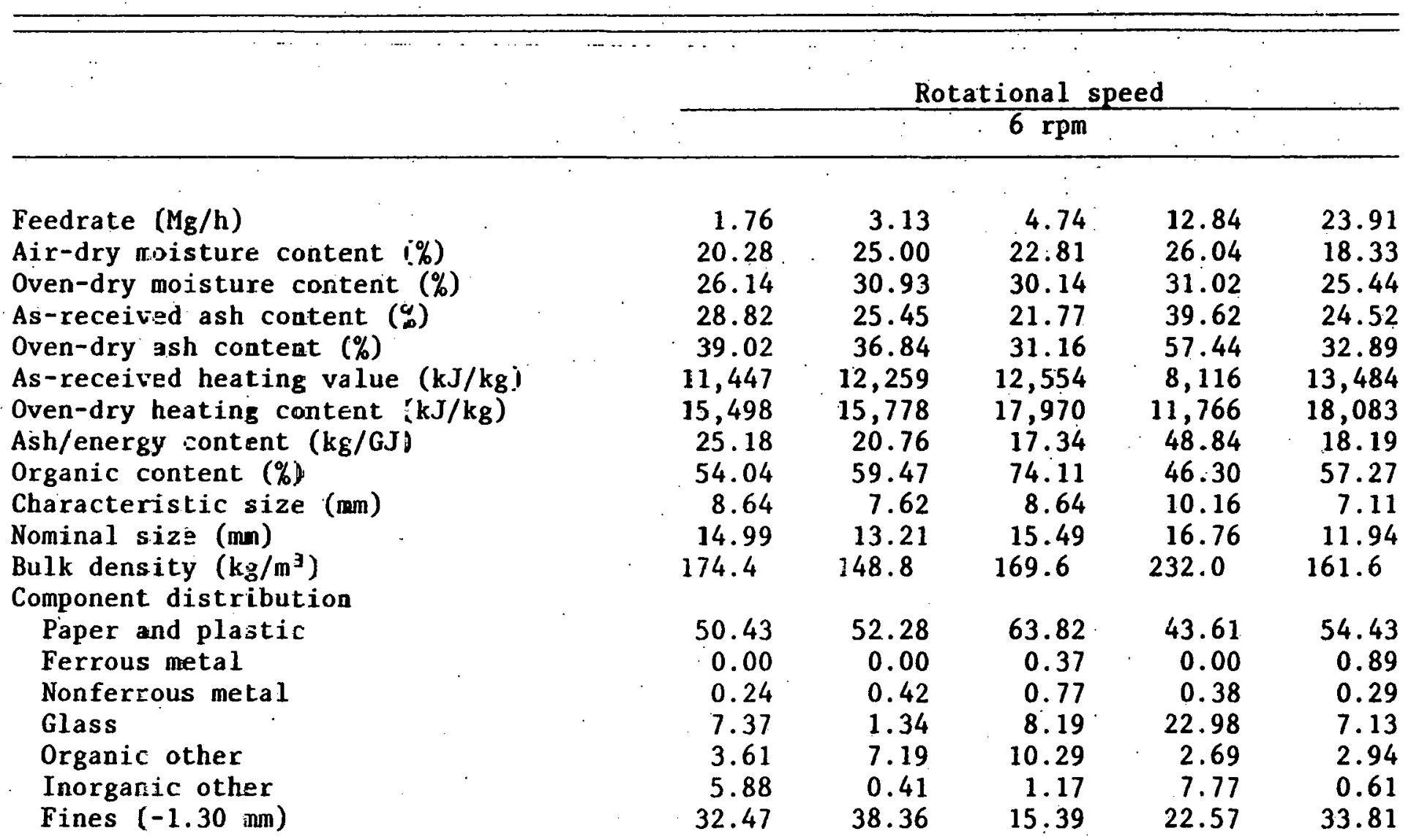

(continued) 


\begin{tabular}{|c|c|c|c|c|c|}
\hline \multirow[b]{3}{*}{ 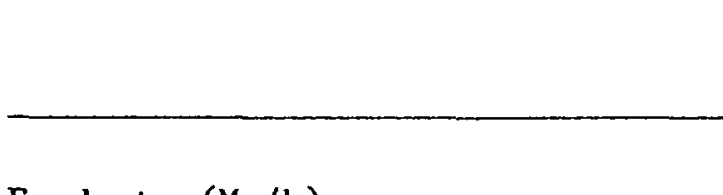 } & \multicolumn{5}{|c|}{ Rotational speed } \\
\hline & \multicolumn{4}{|c|}{$9 \mathrm{rpm}$} & \\
\hline & 2.82 & 5.85 & 10.55 & 15.86 & 22.55 \\
\hline Air-d=y moisture content $(\%)$ & 20.08 & 19.71 & 27.03 & 23.56 & 19.00 \\
\hline Oven-iry moisture content $(\%)$ & 26.31 & 25.86 & 31.10 & 28.15 & 23.33 \\
\hline As-rezeived ash content $(\%)$ & 24.73 & 31.06 & 26.11 & 38.36 & 42.71 \\
\hline Oven-dry ash content $(\%)$ & 33.56 & 41.89 & 52.41 & 43.39 & 55.71 \\
\hline As-received heating value $(\mathrm{kJ} / \mathrm{kg})$ & 15,268 & 11,988 & 7,268 & 7,768 & 9,124 \\
\hline Oven-dry heating contert $(\mathrm{kJ} / \mathrm{kg})$ & 17,048 & 16,170 & 10,548 & 10,812 & 11,901 \\
\hline Ash/energy content $(\mathrm{kg} / \mathrm{GJ})$ & 19.69 & 25.91 & 49.69 & 49.38 & 46.81 \\
\hline Organic content $(\%)$ & 60.80 & 61.95 & 53.42 & 49.17 & 46.26 \\
\hline Characteristic size (mn) & 7.37 & 9.65 & 5.59 & 6.60 & 7.62 \\
\hline Nomiral size (mm) & 14.99 & 18.03 & 12.95 & $12 . .7$ & 11.94 \\
\hline Bulk density $\left(\mathrm{kg} / \mathrm{m}^{3}\right)$ & 99.2 & 179.2 & 193.6 & 185.6 & 244.8 \\
\hline \multicolumn{6}{|l|}{ Component distribution } \\
\hline Paper and plastic & 53.67 & 55.28 & 45.34 & 41.74 & 43.47 \\
\hline Ferrous metal & 0.12 & 0.20 & 0.00 & 0.38 & 0.00 \\
\hline Nonferrous metal & 0.20 & 0.01 & 0.07 & 0.16 & 0.06 \\
\hline Glass & 7.13 & 17.44 & 10.91 & 16.38 & 26.13 \\
\hline Organic other & 7.13 & 6.67 & 8.08 & 7.43 & 2.79 \\
\hline Inorganic other & 0.98 & 4.38 & 2.30 & 7.48 & 0.88 \\
\hline Fines $(-1.30 \mathrm{~mm})$ & 30.77 & 16.02 & 33.30 & 26.43 & 26.67 \\
\hline
\end{tabular}


TABLE C-5. (continued)

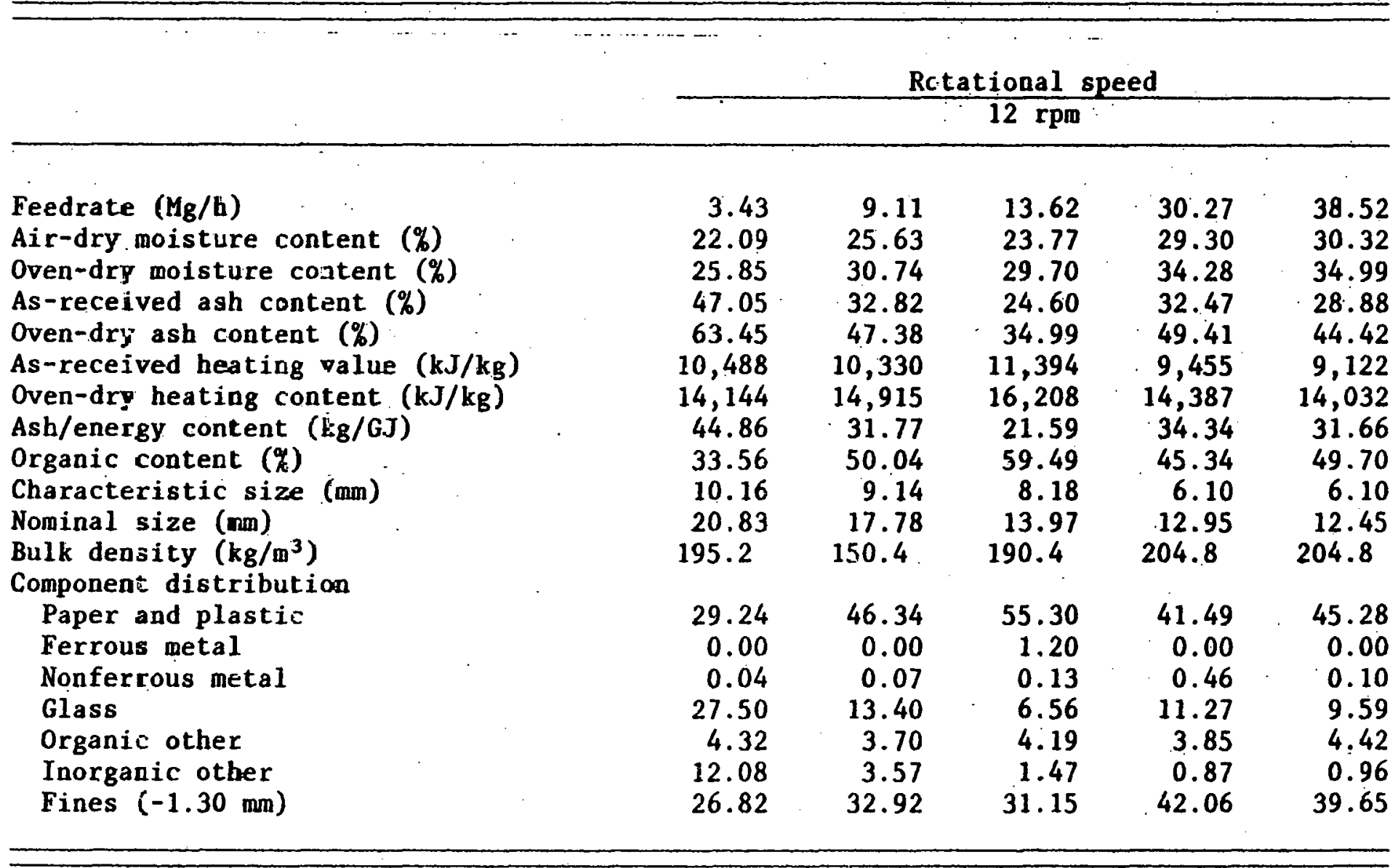


TABLE C-6. TROMMEL PERFORMANCE CHARACTERIZATION - JANUARY 1981

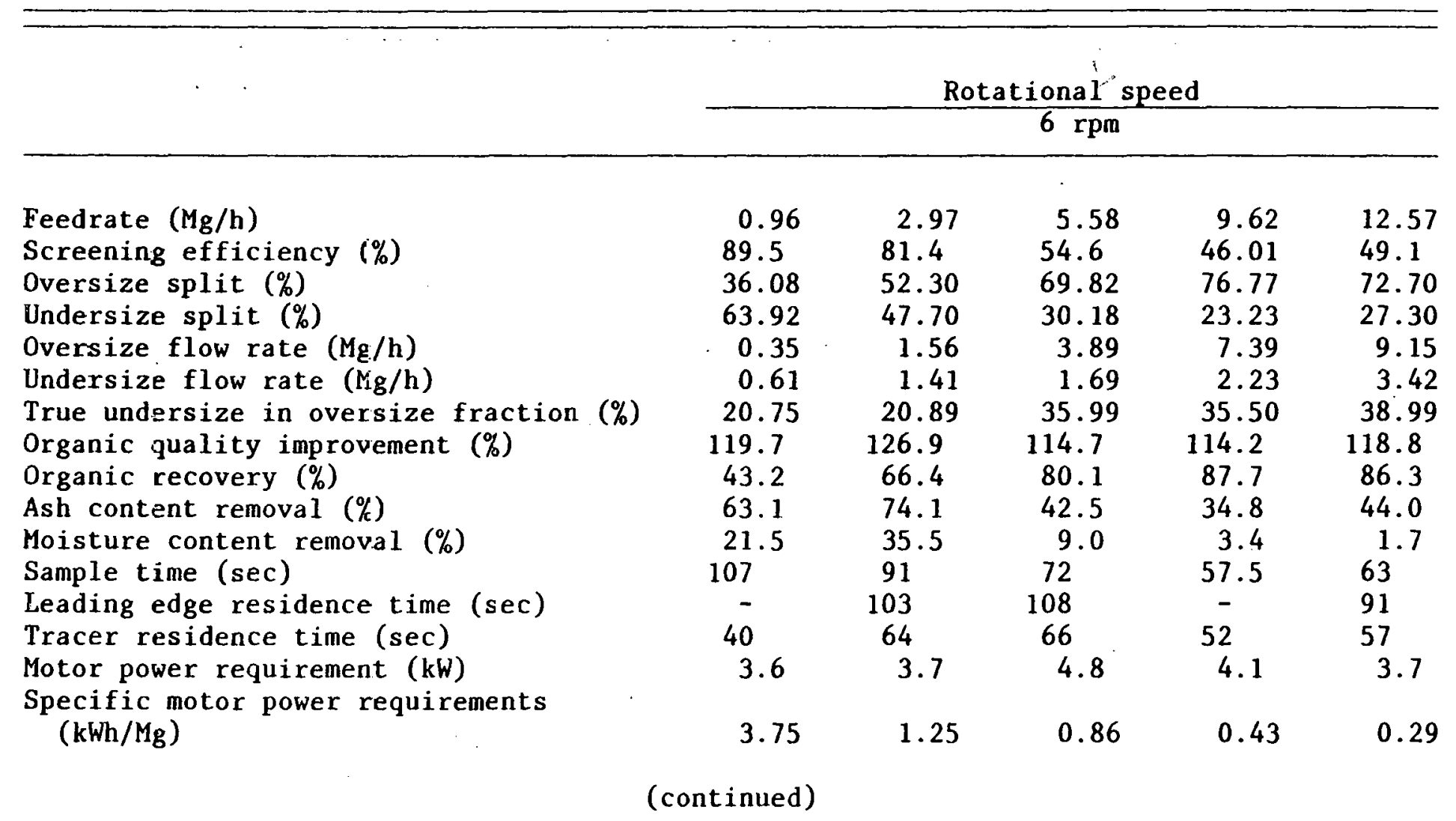


TABLE C-6. (continued)

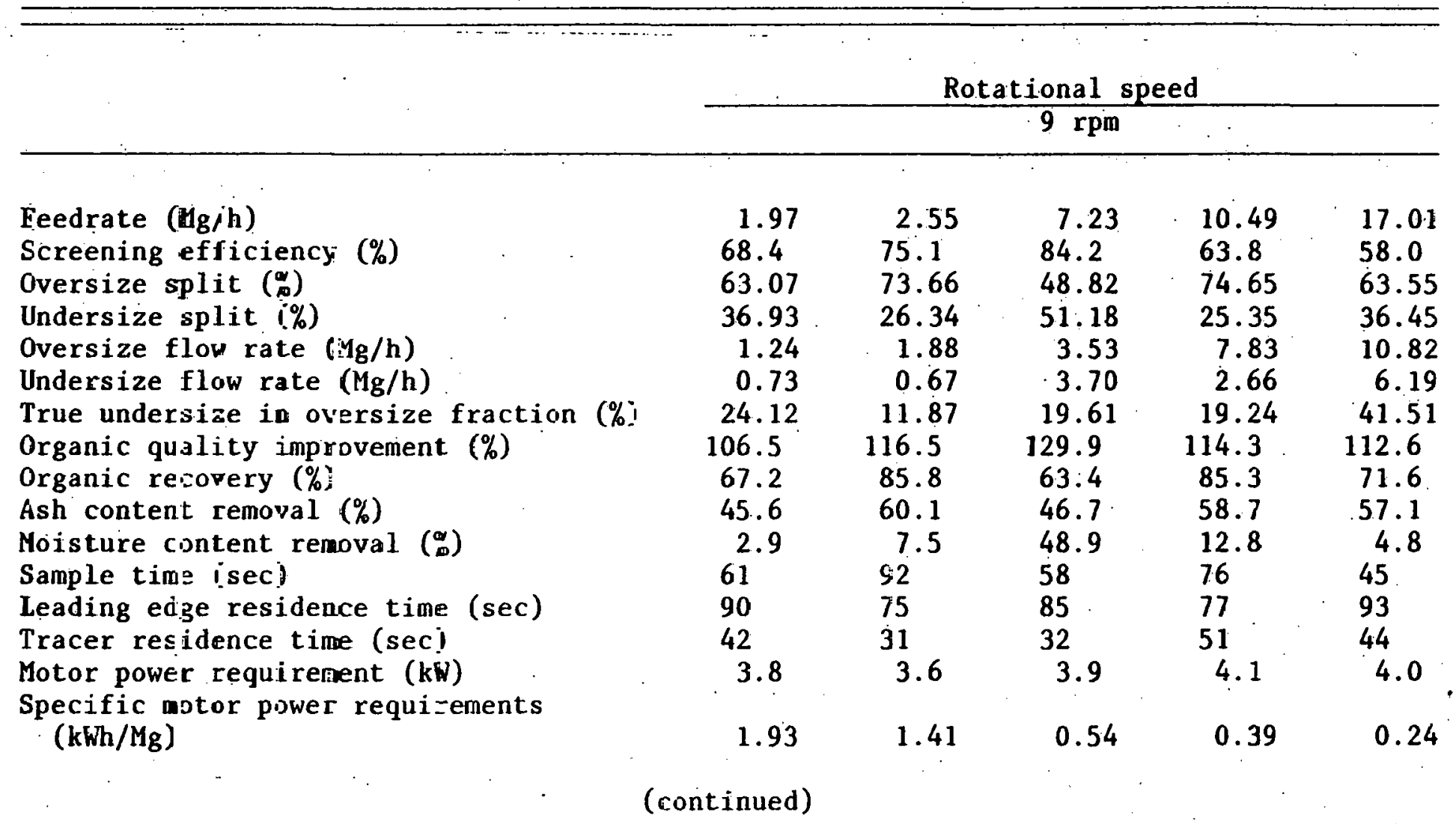


TABLE C-6. (continued)

\begin{tabular}{|c|c|c|c|c|c|}
\hline & & & tionai & & \\
\hline & & & $12 \mathrm{rpm}$ & & \\
\hline Feedrate $(\mathrm{Mg} / \mathrm{h})$ & 3.62 & 6.09 & 6.69 & 7.42 & 17.64 \\
\hline Screening efficiency (\%) & 83.3 & 86.7 & 73.9 & 79.4 & 59.3 \\
\hline Oversize split $(\%)$ & 62.31 & 47.98 & 57.89 & 51.39 & 55.40 \\
\hline Undersize split (\%) & 37.69 & 52.02 & 42.11 & 48.61 & 44.60 \\
\hline Oversize flow rate $(\mathrm{Mg} / \mathrm{h})$ & 2.26 & 2.92 & 3.87 & 3.81 & 9.77 \\
\hline Undersize flow rate $(\mathrm{Mg} / \mathrm{h})$ & 1.36 & 3.17 & 2.82 & 3.61 & 7.87 \\
\hline True undersize in oversize fraction (\%) & 12.10 & 16.67 & 25.70 & 24.50 & 55.31 \\
\hline Organic quality improvement (\%) & 125.0 & 127.6 & 116.7 & 130.5 & 121.7 \\
\hline Organic recovery $(\%)$ & 77.9 & 61.2 & 67.5 & 67.1 & 67.4 \\
\hline Ash content removal (\%) & 65.2 & 55.6 & 53.5 & 69.2 & 59.1 \\
\hline Moisture content removal (\%) & 26.1 & 24.1 & 25.9 & 17.9 & 7.4 \\
\hline Sample time (sec) & 40 & 38 & 40.5 & 70 & 34 \\
\hline Leading edge residence time (sec) & 58 & 61 & 73 & 59 & 64 \\
\hline Tracer residence time (sec) & 26 & 32 & 32 & 28 & 32 \\
\hline Motar power requirement (kW) & 3.5 & 3.6 & 3.8 & 3.9 & 5.8 \\
\hline Specific motor power requirements & & & & & \\
\hline$(\mathrm{kWh} / \mathrm{Mg})$ & 0.97 & 0.51 & 0.57 & 0.53 & 0.33 \\
\hline
\end{tabular}


TABLE C-7. FROPERTIES OF FEED MATERIAL - JANUARY 1981

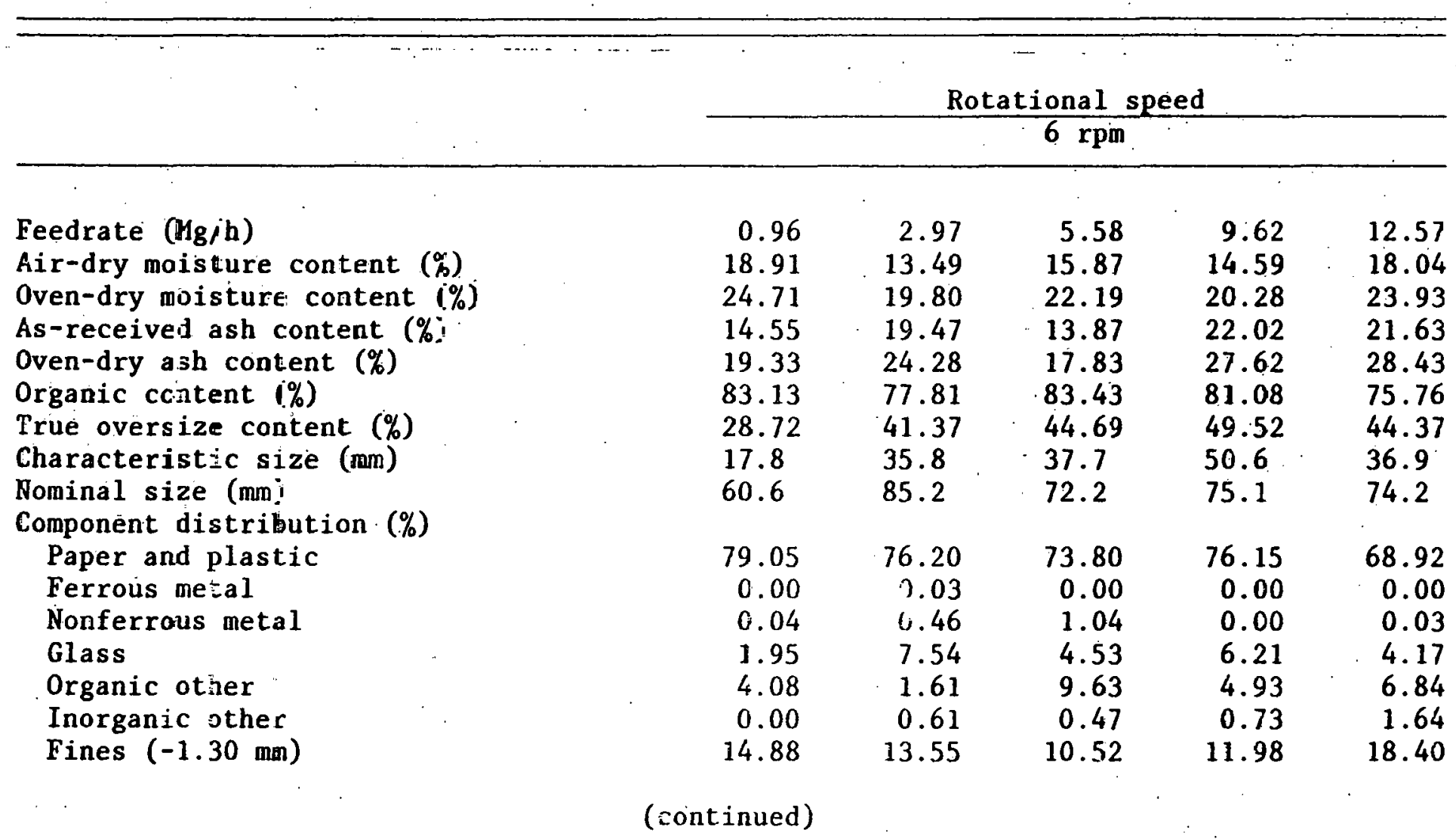


TABLE $\mathrm{C}-7 . \quad$ (continued)

\begin{tabular}{|c|c|c|c|c|c|}
\hline & \multicolumn{5}{|c|}{ Rotational speed } \\
\hline & \multicolumn{5}{|c|}{$9 \mathrm{rpm}$} \\
\hline Feedrate $(\mathrm{Mg} / \mathrm{h})$ & 1.97 & 2.55 & 7.23 & 10.49 & 17.01 \\
\hline Air-dry moisture content $(\%)$ & 0.00 & 14.74 & 13.66 & 19.97 & 24.49 \\
\hline Oven-dry moisture content $(\%)$ & 7.21 & 20.91 & 18.88 & 24.79 & 29.71 \\
\hline As-received ash content $(\%)$ & 11.68 & 17.42 & 27.49 & 15.55 & 15.54 \\
\hline Oven-dry ash content (\%) & 12.59 & 22.03 & 33.89 & 20.67 & 22.11 \\
\hline Organic content $(\%)$ & 93.58 & 83.93 & 74.96 & 84.78 & 83.39 \\
\hline True oversize content (\%) & 47.86 & 64.92 & 39.24 & 60.28 & 37.17 \\
\hline Characteristic size (mm) & 85.7 & 95.0 & 27.4 & 56.0 & 24.1 \\
\hline Nominal size (mm) & 73.1 & 92.7 & 81.7 & 88.9 & 86.0 \\
\hline \multicolumn{6}{|l|}{ Component distribution $(\%)$} \\
\hline Paper and plastic & 91.37 & 78.14 & 69.94 & 81.28 & 79.20 \\
\hline Ferrous metal & 0.00 & 0.01 & 0.03 & 0.00 & 0.00 \\
\hline Nonferrous metal & 0.29 & 0.60 & 0.86 & 0.33 & 0.11 \\
\hline Glass & 0.68 & 5.93 & 6.07 & 5.63 & 3.95 \\
\hline Organic other & 2.21 & 5.79 & 5.02 & 3.50 & 4.19 \\
\hline Inorganic other & 0.26 & 0.60 & 0.67 & 0.78 & 0.61 \\
\hline Fines $(-1.30 \mathrm{~mm})$ & 5.19 & 8.93 & 17.41 & 8.48 & 11.94 \\
\hline
\end{tabular}


TABLE C-7. (continued)

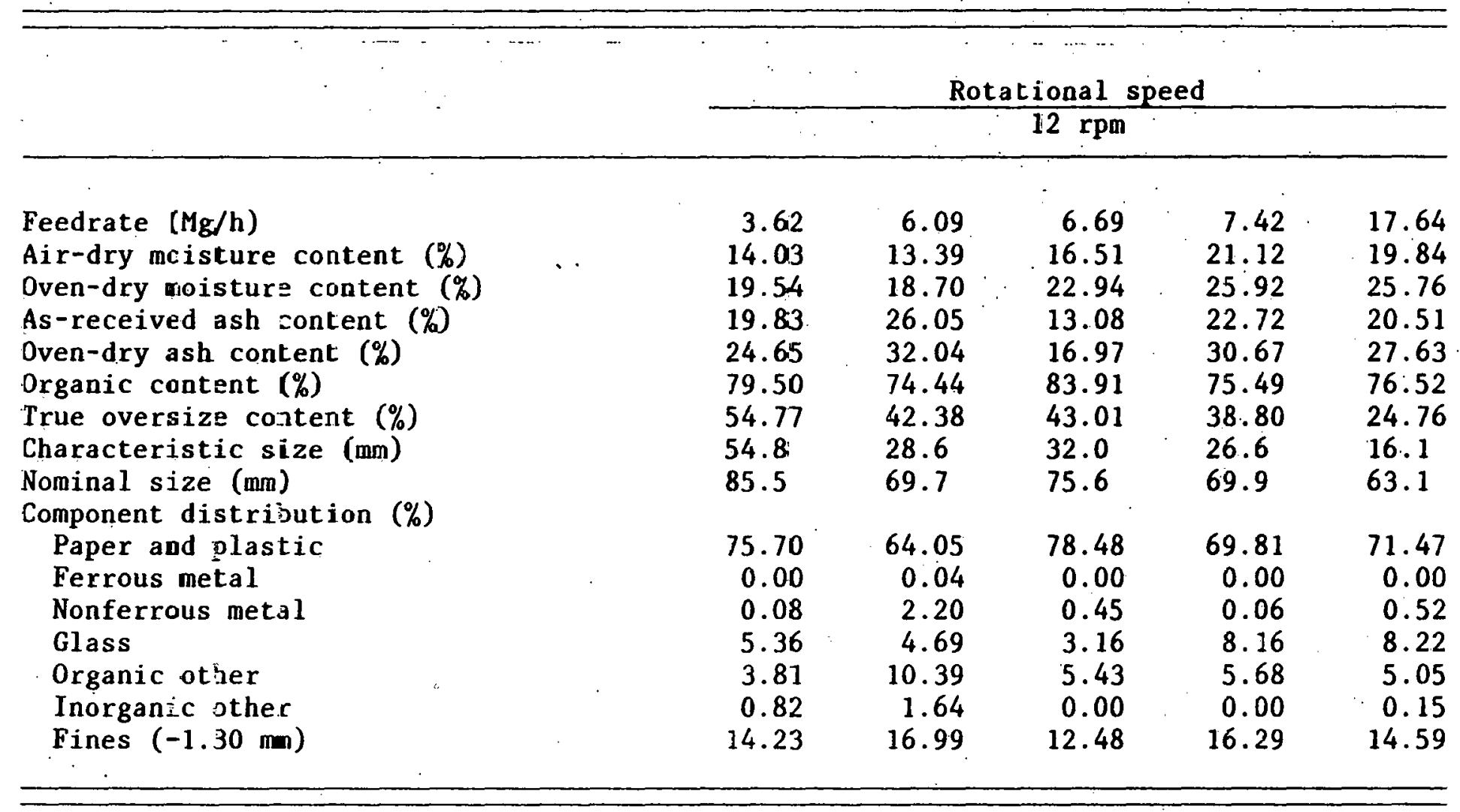


TABLE C-8. PROPERTIES OF OVERSIZE FRACTION - JANUARY 1981

Feedrate $(\mathrm{Mg} / \mathrm{h})$

Air-dry moisture content $(\%)$

Oven-dry moisture content (\%)

As-received ash content (\%)

Oven-dry ash content (\%)

Organic content (\%)

Characteristic size $(\mathrm{mm})$

Nominal size $(\mathrm{mm})$

Bulk density $\left(\mathrm{kg} / \mathrm{m}^{3}\right)$

Component distribution

Paper and plastic

Ferrous metal

Nonferrous metal

Glass

Organic other

Inorganic other

Fines $(-1.30 \mathrm{~mm})$ $\frac{\text { Rotational speed }}{6 \mathrm{rpm}}$

$\frac{\text { Rotational speed }}{6 \mathrm{rpm}}$

$\begin{array}{rrrrl}0.96 & 2.97 & 5.58 & 9.62 & 12.57 \\ 13.04 & 4.55 & 13.33 & 13.33 & 17.07 \\ 19.41 & 12.78 & 20.19 & 19.60 & 23.53 \\ 5.37 & 5.04 & 7.97 & 14.35 & 12.11 \\ 6.66 & 5.78 & 9.99 & 17.85 & 15.84 \\ 99.49 & 98.73 & 95.71 & 92.58 & 89.97 \\ 53.6 & 70.5 & 55.7 & 58.5 & 54.0 \\ 73.9 & 93.0 & 75.4 & 95.5 & 98.2 \\ 32.04 & 28.84 & 39.41 & 43.89 & 47.26 \\ 98.86 & 98.38 & 87.60 & 89.41 & 94.03 \\ 0.00 & 0.05 & 0.00 & 0.00 & 0.00 \\ 0.00 & 0.43 & 1.48 & 0.00 & 0.00 \\ 0.00 & 0.00 & 0.47 & 1.89 & 1.28 \\ 0.63 & 0.35 & 8.11 & 3.17 & 5.94 \\ 0.00 & 0.09 & 0.10 & 0.95 & 0.73 \\ 0.51 & 0.70 & 2.24 & 4.58 & 8.02\end{array}$

(continued) 
TABLE C-8. (continued)

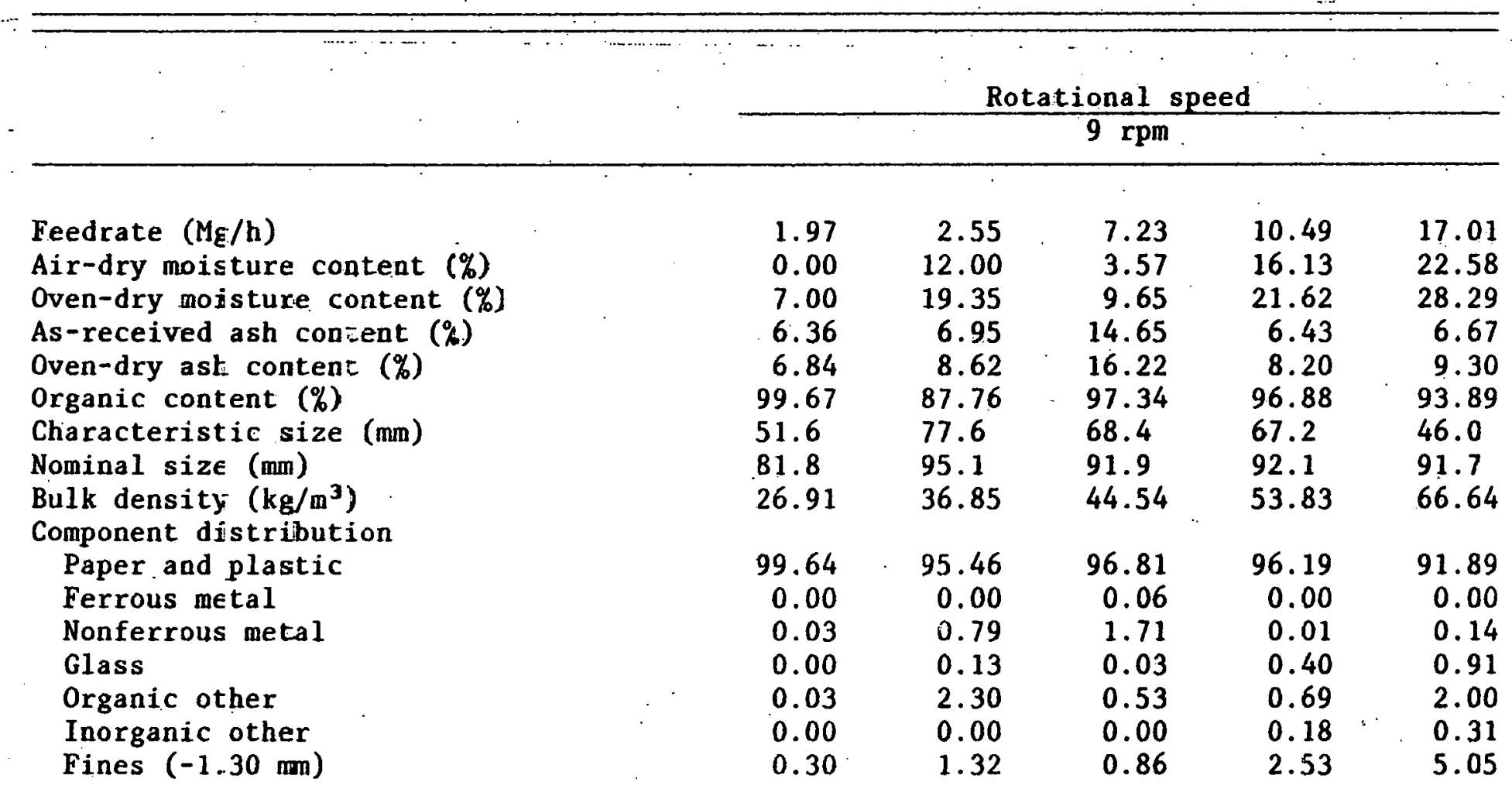

(continued) 
TABLE C-8. (continued)

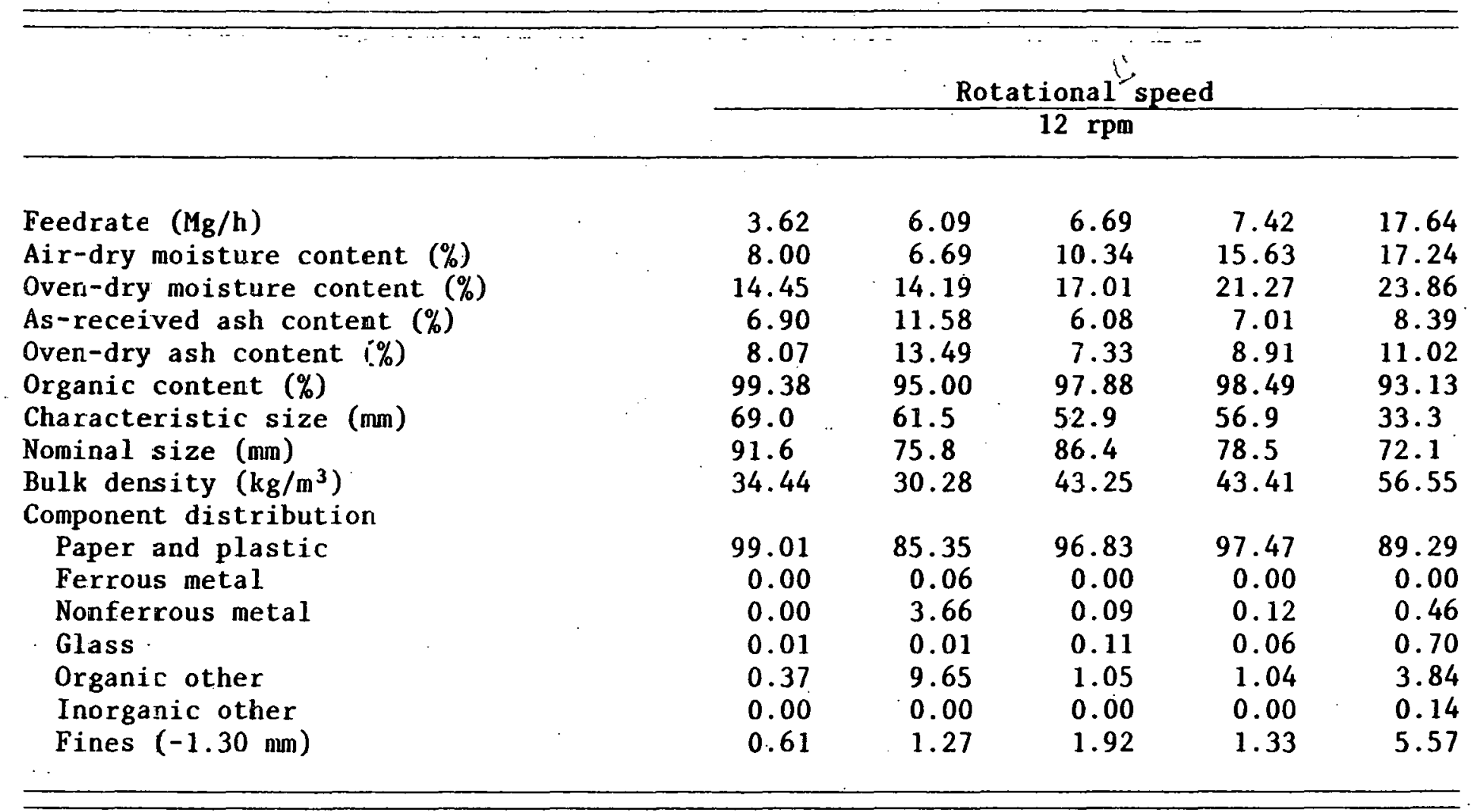


TABLE C-9. PROPERTIES OF UNDERSIZE FRACTION - JANUARY 1981

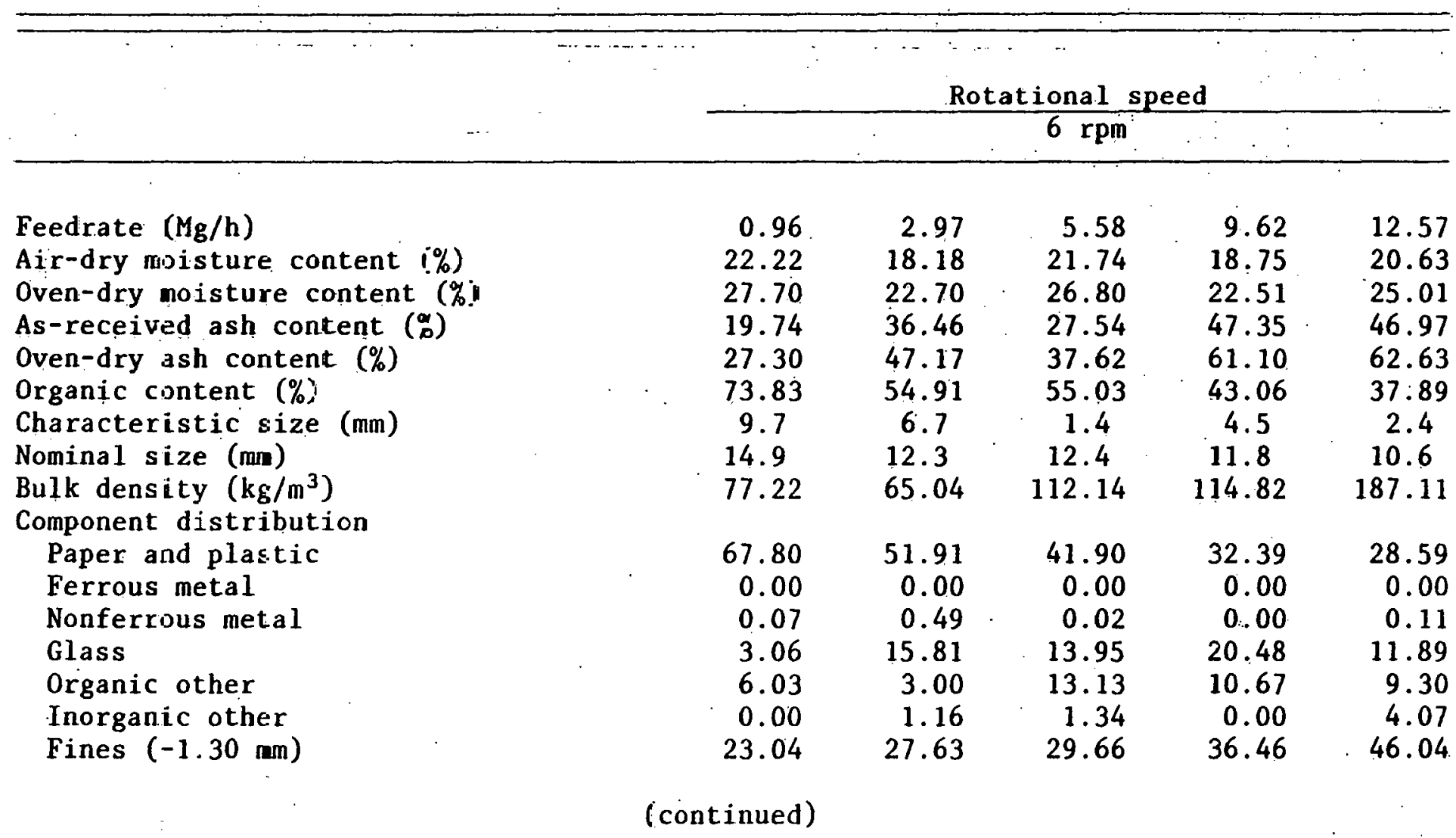


TABLE C-9. (continued)

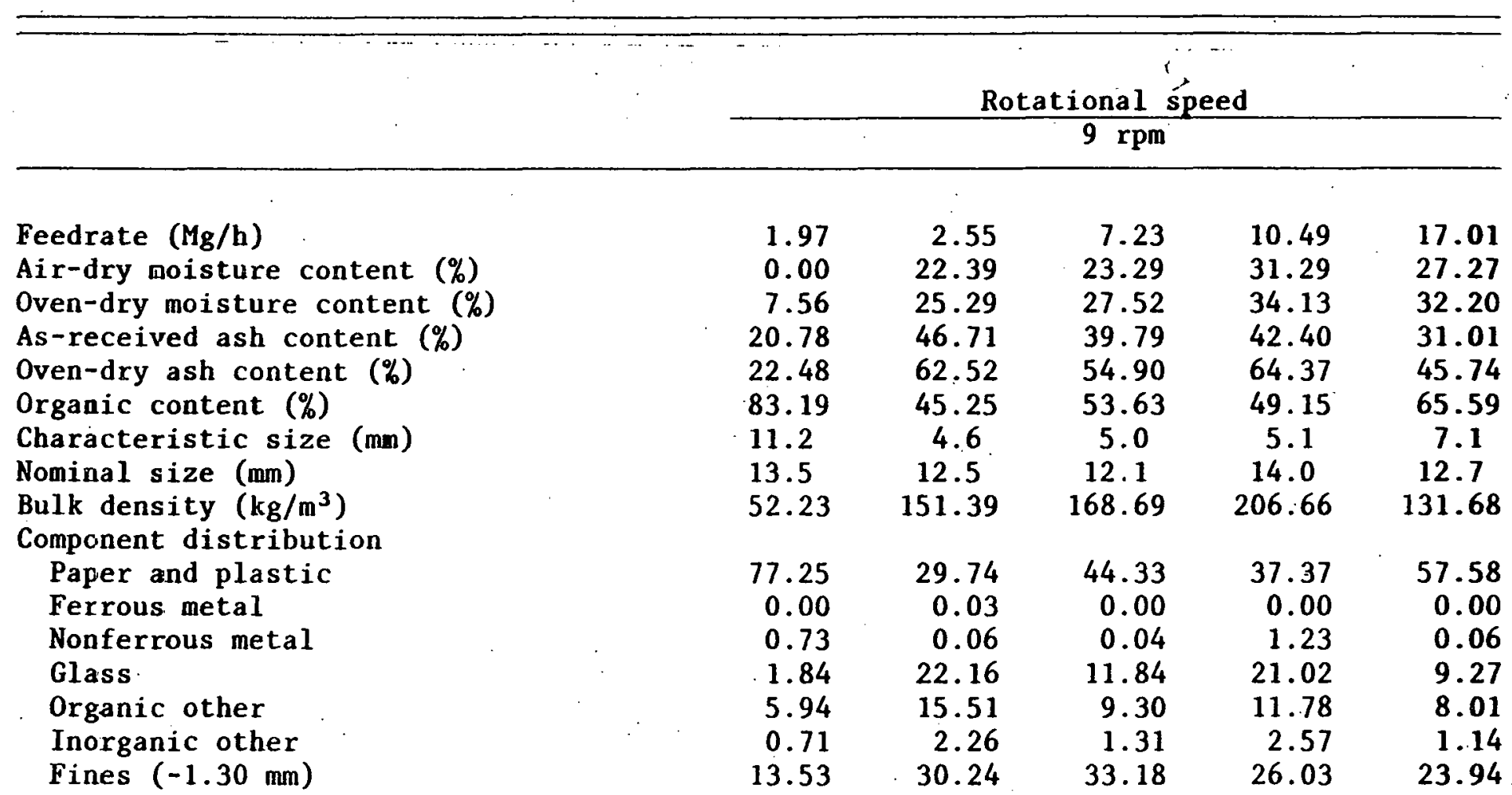

(continued) 
TABLE C-9. (continued)

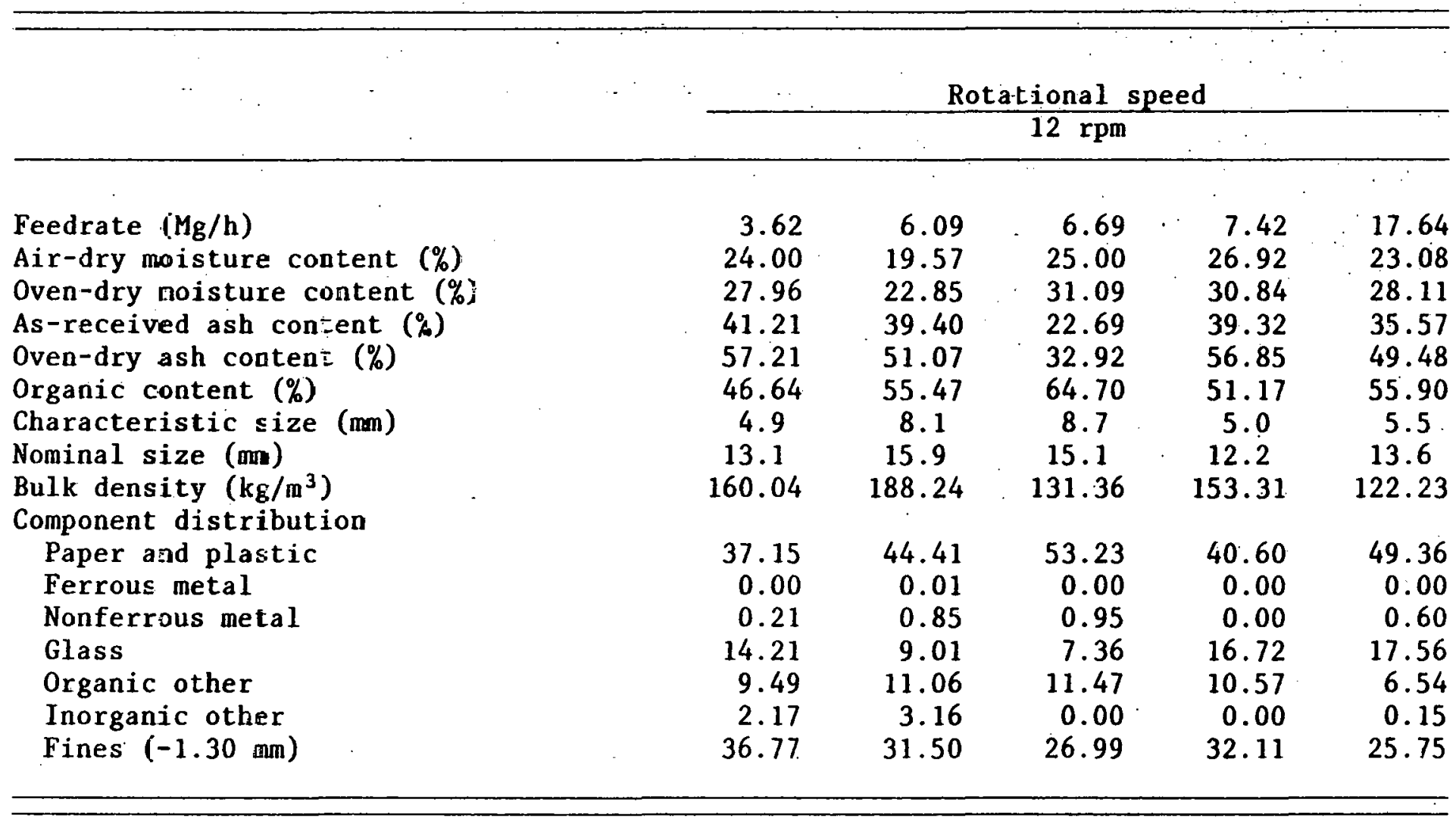


TABLE C-10. TROMMEL PERFORMANCE CHARACTERIZATION - MAY 1981

Rotational speed

$6 \mathrm{rpm}$

\begin{tabular}{|c|c|c|c|c|c|}
\hline Feedrate $(\mathrm{Mg} / \mathrm{h})$ & 2.82 & 5.05 & 5.21 & 26.44 & 29.56 \\
\hline Screening efficiency (\%) & 90.3 & 70.3 & 96.1 & 23.3 & 23.9 \\
\hline Oversize split $(\%)$ & 38.26 & 29.84 & 18.93 & 79.25 & 80.64 \\
\hline Undersize split (\%) & 61.74 & 70.16 & 81.07 & 20.75 & 19.36 \\
\hline Oversize flow rate $(\mathrm{Mg} / \mathrm{h})$ & 1.08 & 1.52 & 0.99 & 20.96 & 23.84 \\
\hline Undersize flow rate $(\mathrm{Mg} / \mathrm{h})$ & 1.74 & 3.53 & 4.22 & 5.48 & 5.72 \\
\hline True undersize in oversize fraction (\%) & 17.4 & 65.4 & 17.5 & 86.3 & 76.7 \\
\hline Heating value improvement $(\%)$ & 155.7 & 146.9 & 186.4 & 107.3 & 107.8 \\
\hline Energy recovery $(\%)$ & 59.6 & 43.8 & 35.3 & 85.0 & 86.9 \\
\hline \multicolumn{6}{|l|}{ Ash/energy content of oversize } \\
\hline $\begin{array}{l}\text { Iraction (kg/GJ) } \\
\text { Organic quality improvement }(\%)\end{array}$ & 4.13 & $\begin{array}{r}7.24 \\
143.3\end{array}$ & $\begin{array}{r}5.95 \\
35.0\end{array}$ & $\begin{array}{r}17.47 \\
105.7\end{array}$ & $\begin{array}{r}5.38 \\
108.1\end{array}$ \\
\hline Organic recovery $(\%)$ & 50.2 & $\begin{array}{r}145.3 \\
42.8\end{array}$ & 25.6 & 83.8 & 87.1 \\
\hline Ash content removal $(\%)$ & 67.0 & 44.0 & 51.8 & 5.4 & 20.8 \\
\hline Moisture content removal $(\%)$ & 34.6 & 13.6 & 25.8 & 4.7 & 2.5 \\
\hline Sample time (sec) & 65 & 58 & 49 & 24 & 24 \\
\hline Leading edge residence time (sec) & 102 & 109 & 99 & 81 & 74 \\
\hline Tracer residence time (sec) & 61 & 59 & 48 & 58 & 64 \\
\hline Motor power requirement $(\mathrm{kW})$ & 3.7 & 4.1 & 3.7 & 5.3 & 4.4 \\
\hline \multirow{2}{*}{$\begin{array}{l}\text { Specific motor power requirements } \\
(\mathrm{kWh} / \mathrm{Mg})\end{array}$} & & & & & \\
\hline & 1.31 & 0.81 & 0.71 & 0.20 & 0.15 \\
\hline
\end{tabular}


TABLE $c-10 . \quad$ (continued)

Rotational speed

$9 \mathrm{rpm}$

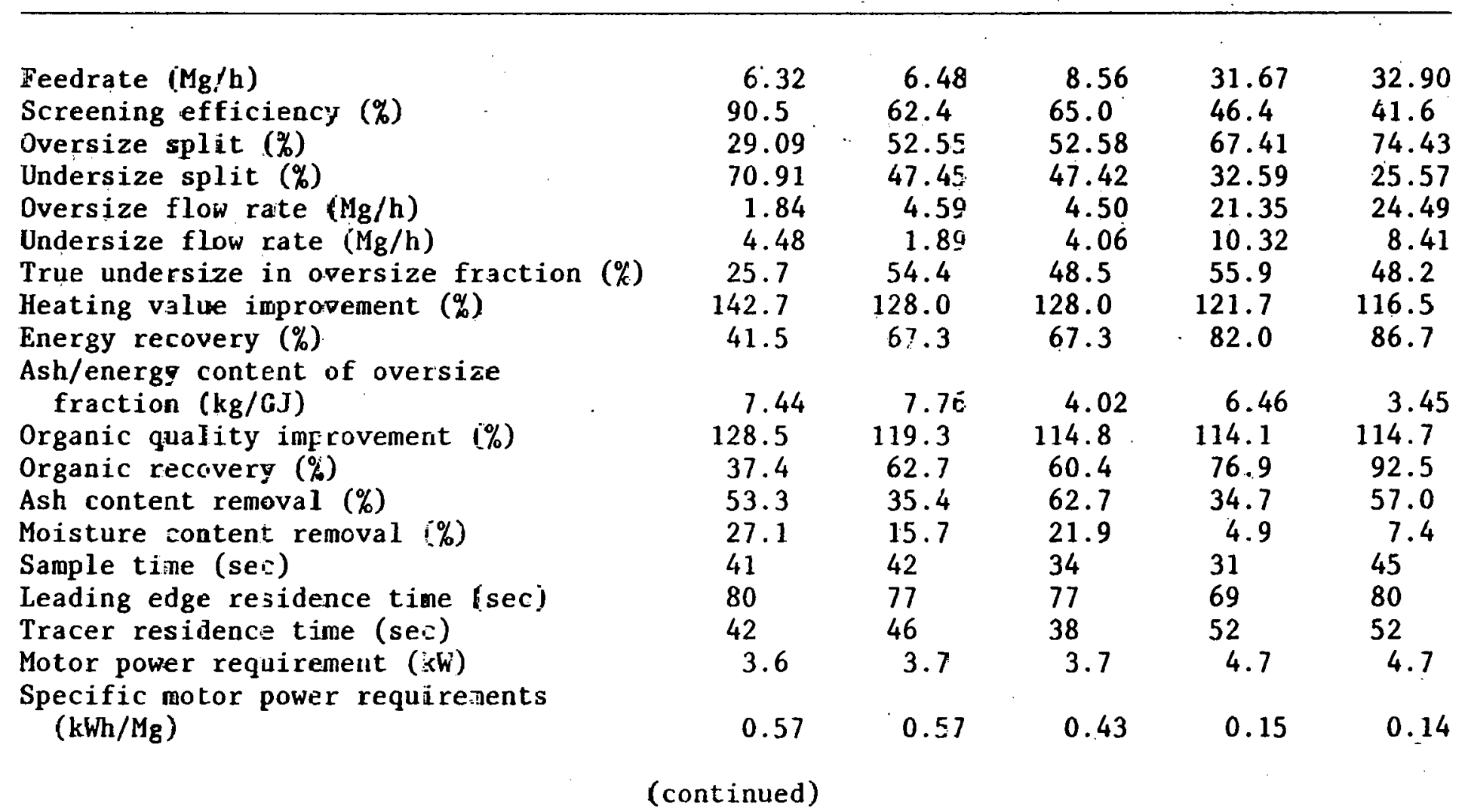


TABLE C-10. (continued)

\begin{tabular}{|c|c|c|c|c|c|}
\hline - & \multicolumn{5}{|c|}{$\begin{array}{l}\text { Rotational speed } \\
12 \mathrm{rpm}\end{array}$} \\
\hline Feedrate $(\mathrm{Mg} / \mathrm{h})$ & 2.92 & 9.90 & 10.59 & 17.69 & 46.55 \\
\hline Screening efficiency $(\%)$ & 68.0 & 78.0 & 65.9 & 57.0 & 25.9 \\
\hline Oversize split $(\%)$ & 63.72 & 38.91 & 56.04 & 60.93 & 81.97 \\
\hline Undersize split (\%) & 36.28 & 61.09 & 43.96 & 39.07 & 18.03 \\
\hline Oversize flow rate $(\mathrm{Mg} / \mathrm{h})$ & 1.86 & 3.86 & 5.94 & 10.78 & 38.16 \\
\hline Undersize flow rate $(\mathrm{Mg} / \mathrm{h})$ & 1.06 & 6.04 & 4.65 & 6.91 & 8.39 \\
\hline True undersize in oversize fraction (\%) & 26.9 & 44.2 & 40.6 & 48.4 & 63.0 \\
\hline Heating value improvement $(\%)$ & 122.1 & 141.6 & 123.4 & 119.7 & 113.5 \\
\hline Energy recovery $(\%)$ & 77.8 & 55.1 & 69.1 & 72.9 & 93.0 \\
\hline \multicolumn{6}{|l|}{ Ash/energy content of oversize } \\
\hline fraction $(\mathrm{kg} / \mathrm{GJ})$ & 4.30 & 4.63 & 10.81 & 15.08 & $10: 10$ \\
\hline Organic quality improvement $(\%)$ & 108.9 & 122.2 & 114.7 & 113.2 & $109: 7$ \\
\hline Organic recovery $(\%)$ & 69.4 & 47.6 & 64.3 & 69.0 & 89.9 \\
\hline Ash content removal (\%) & 27.2 & 57.4 & 7.9 & $(-4.3)$ & 25.5 \\
\hline Moisture content removal (\%) & 21.9 & 29.1 & 14.7 & 12.4 & $(-2.3)$ \\
\hline Sample time (sec) & 36 & 34 & 29 & 19 & 21 \\
\hline Leading edge residence time (sec) & 63 & 75 & 65 & 62 & 59 \\
\hline Tracer residence time (sec) & 35 & 34 & 42 & 32 & 47 \\
\hline Motor power requirement $(\mathrm{kW})$ & 3.7 & 3.9 & 3.6 & 4.1 & 6.1 \\
\hline \multirow{2}{*}{$\begin{array}{l}\text { Specific motor power requirements } \\
(\mathrm{kWh} / \mathrm{Mg})\end{array}$} & & & & & \\
\hline & 1.27 & 0.39 & 0.34 & 0.23 & 0.13 \\
\hline
\end{tabular}


TABLE C-11. PROPERTIES OF FEED MATERIAL - MAY 1981

\section{Rotational speed}

$6 \mathrm{rpm}$

Feedrate (Hg/a)
Air-dry moistare content $(\%)$
Oven-dry moisture content $(\%)$
As-received ash content $(\%)$
Oven-dry ash content $(\%)$
As-received heating value (kJ/kg)
Oven-dry heating content (kJ/kg)
Ash/energy content (kg/6J)
Organic content (\%)
True oversize content $(\%)$
Characteristic size (mm)
Nominal size (mm)
Component distritution $(\%)$
Paper and plastic
Ferrous aetal
Nonferrous metal
Glass
Organic otrer
Inorganic other
Fines (-1.30 mm)

(continued)

$\begin{array}{rrrrr}2.82 & 5.05 & 5.21 & 26.44 & 29.56 \\ 24.88 & 25.29 & 24.53 & 32.67 & 21.83 \\ 30.65 & 31.11 & 31.07 & 38.59 & 28.54 \\ 19.63 & 18.44 & 19.06 & 15.99 & 9.29 \\ 28.30 & 26.77 & 27.65 & 26.04 & 13.00 \\ 10,067 & 9,711 & 3,278 & 8,067 & 12,696 \\ 14,516 & 14.097 & 12,009 & 13,136 & 17,766 \\ 19.5 & 18.99 & 23.02 & 19.82 & 7.32 \\ 74.13 & 63.66 & 71.47 & 54.28 & 80.97 \\ 31.6 & 10.4 & 15.7 & 10.9 & 18.8 \\ 19.1 & 8.6 & 8.9 & 6.4 & 14.2 \\ 73.2 & 25.1 & 40.9 & 25.1 & 45.0 \\ & & & & \\ 62.86 & 51.33 & 50.00 & 36.53 & 67.88 \\ 0.00 & 0.00 & 0.00 & 0.00 & 0.00 \\ 1.27 & 0.12 & 0.50 & 0.04 & 0.07 \\ 5.31 & 8.38 & 2.91 & 9.72 & 2.47 \\ 11.28 & 12.33 & 21.46 & 17.74 & 13.09 \\ 0.00 & 2.05 & 0.43 & 0.63 & 0.35 \\ 19.28 & 25.79 & 24.70 & 35.34 & 16.14\end{array}$


TABLE C-11. (continued)

Rotational speed

$9 \mathrm{rpm}$

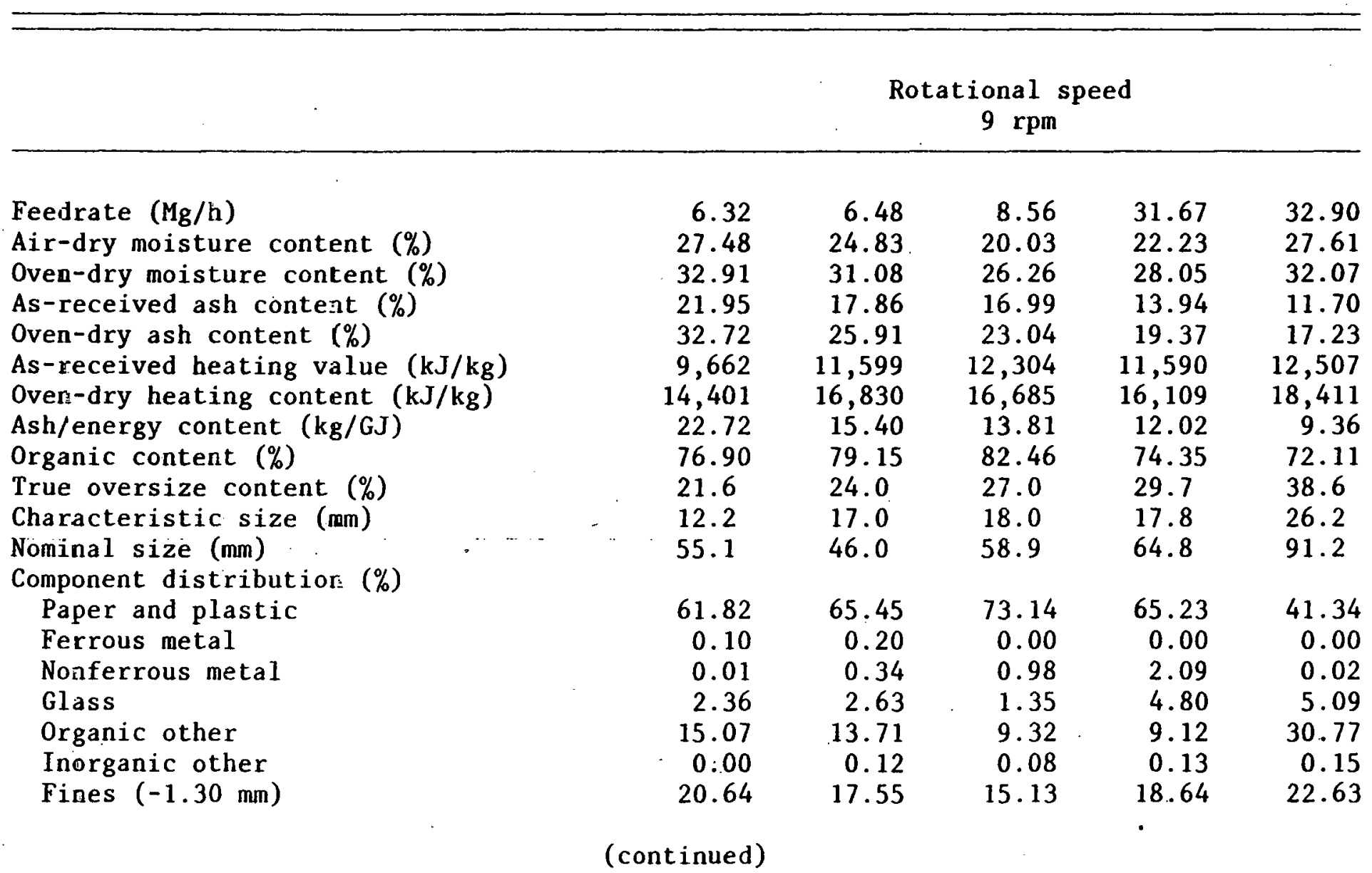


TABLE C-11. (continued)

\begin{tabular}{|c|c|c|c|c|c|}
\hline \multirow[t]{2}{*}{. } & \multicolumn{5}{|c|}{$\begin{array}{l}\text { Rotational speed } \\
\qquad 12 \mathrm{rpm}\end{array}$} \\
\hline & & & & & \\
\hline Feedrate $(\mathrm{Mg} / \mathrm{h})$ & 2.92 & 9.90 & 10.59 & 17.69 & 46.55 \\
\hline Air-dry moisture content $(\%)$ & 16.55 & 25.25 & 21.93 & 28.21 & 9.57 \\
\hline Oven-dry moisture content $(\%)$ & 24.18 & 31.77 & 29.03 & 34.52 & 16.75 \\
\hline As-received ash content $(\stackrel{\circ}{h})$ & 9.93 & 17.26 & 16.42 & 17.88 & 21.30 \\
\hline Oven-dry ash cortent $(\%)$ & 13.10 & 25.30 & 23.13 & 27.30 & 25.58 \\
\hline As-received heating value $(\mathrm{kJ} / \mathrm{kg})$ & 13,762 & 11,214 & 11,345 & 10,330 & 13,853 \\
\hline Oven-dry heating content $(\mathrm{kJ} / \mathrm{kg})$ & 18,151 & 16,436 & 15,985 & 15,776 & 16,640 \\
\hline Ash/energy content $(\mathrm{kg} / \mathrm{GJ}$ & 7.22 & 15.39 & 14.47 & 17.30 & 15.37 \\
\hline Organic content $(\%)$ & 90.93 & 78.32 & 84.42 & 82.80 & 79.82 \\
\hline True oversize content $(\%)$ & 46.7 & 21.7 & 33.3 & 31.4 & 30.3 \\
\hline Characteristic size (mm) & 14.2 & 13.2 & 21.8 & 20.3 & 19.6 \\
\hline Nominal size (mm) & 83.1 & 46.2 & 57.9 & 77.5 & 69.9 \\
\hline $\begin{array}{l}\text { Component distribution }(\% ! \\
\text { Paper and plastic }\end{array}$ & 83.26 & 62.65 & 73.70 & 59.14 & 77.36 \\
\hline Ferrous metal & 0.00 & 0.00 & 0.00 & 0.00 & 0.01 \\
\hline Nonferrous metal & 0.00 & 0.16 & 0.07 & 0.18 & 0.10 \\
\hline Glass & 0.72 & 1.49 & 1.22 & 1.46 & 7.32 \\
\hline Organic other & 7.67 & 15.67 & 10.72 & 23.66 & 2.46 \\
\hline Inorganic other & 0.02 & 0.06 & 0.67 & 0.08 & 0.35 \\
\hline Fines $(-1.30 \mathrm{~mm})$ & 8.33 & 19.97 & 13.62 & 15.48 & 12.40 \\
\hline
\end{tabular}


TABLE C-12. PROPERTIES OF OVERSIZE FRACTION - MAY 1981

\begin{tabular}{|c|c|c|c|c|c|}
\hline & \multicolumn{5}{|c|}{$\begin{array}{c}\text { Rotational speed } \\
6 \mathrm{rpm}\end{array}$} \\
\hline Feedrate $(\mathrm{Mg} / \mathrm{h})$ & 2.82 & 5.05 & 5.21 & 26.44 & 29.56 \\
\hline Air-dry moisture content (\%) & 12.82 & 20.0 & 15.38 & 30.61 & 21.28 \\
\hline Oven-dry moisture conient (\%) & 20.06 & 26.87 & 23.07 & 36.77 & 27.82 \\
\hline As-received ash content $(\%)$ & 6.48 & 10.33 & 9.18 & 15.12 & 7.36 \\
\hline Oven-dry ash content i\%) & 8.10 & 14.12 & 11.93 & 23.91 & 10.2 \\
\hline As-received heating value $(\mathrm{kJ} / \mathrm{kg})$ & 15,675 & 14,263 & 15,432 & 8,654 & 13,687 \\
\hline Oven-dry heating content $(\mathrm{kJ} / \mathrm{kg})$ & 19,608 & 19,503 & 20,060 & 13,687 & 18,963 \\
\hline Ash/energy content $(\mathrm{kg} / \mathrm{GJ})$ & 4.13 & 7.24 & 5.95 & 17.47 & 5.38 \\
\hline Organic content $(\%)$ & 97.19 & 91.21 & 96.46 & 57.38 & 87.50 \\
\hline Characteristic size (mm) & 64.0 & 23.1 & 50.0 & 8.6 & 17.8 \\
\hline Nominal size $(\mathrm{mm})$ & 90.4 & 53.1 & 75.9 & 31.8 & 50.5 \\
\hline Bulk density $\left(\mathrm{kg} / \mathrm{m}^{3}\right)$ & 40.7 & 31.4 & 35.6 & 63.6 & 0.00 \\
\hline \multicolumn{6}{|l|}{ Component distribution $(\%)$} \\
\hline Paper and plastic & 96.29 & 84.19 & 89.10 & 39.93 & 74.51 \\
\hline Ferrous metal & 0.00 & 0.00 & 0.00 & 0.00 & 0.00 \\
\hline Nonferrous metal & 1.31 & 0.00 & 2.43 & 0.03 & 0.06 \\
\hline Glass & 0.00 & 0.78 & 0.00 & 9.06 & 1.36 \\
\hline Organic other & 0.90 & 7.02 & 7.36 & 17.45 & 12.02 \\
\hline Inorganic other & 0.00 & 0.00 & 0.00 & 0.68 & 0.13 \\
\hline Fines $(-1.30 \mathrm{~mm})$ & 1.50 & 8.01 & 1.11 & 32.85 & 11.92 \\
\hline
\end{tabular}

(continued) 
TABLE C-12. (continued)

Rotational speed

$9 \mathrm{rpm}$

\begin{tabular}{|c|c|c|c|c|c|}
\hline Feedrate $(\mathrm{Mg} / \mathrm{h})$ & 6.32 & 6.48 & 8.56 & 31.67 & 32.90 \\
\hline Air-dry moisture content $(\%)$ & 17.50 & 19.64 & 13.33 & 20.78 & 25.23 \\
\hline Oven-dry moisture content $(\%)$ & 23.98 & 26.21 & 20.50 & 26.68 & 29.69 \\
\hline As-received ash zontent $(\%)$ & 10.26 & 11.53 & 6.33 & 9.11 & 5.03 \\
\hline Oven-dry ash content $(\%)$ & 13.49 & 15.62 & 7.96 & 12.43 & 7.15 \\
\hline As-received heating value $\left(\mathrm{kJ}_{/} / \mathrm{kg}\right)$ & 13,789 & 14,852 & 15,755 & 14,106 & 14,569 \\
\hline Dven-dry heating content $(\mathrm{kJ} / \mathrm{kg})$ & 18,138 & 20.127 & 19,817 & 19,239 & 20,721 \\
\hline Ash/energy content $(\mathrm{kg} / \mathrm{GJ})$ & 7.44 & 7.76 & 4.02 & 6.46 & 3.45 \\
\hline Organic ccntent $(\%)$ & 98.84 & 94.46 & 94.70 & 84.81 & 82.74 \\
\hline Characteristic size $(\mathrm{mm})$ & 52.6 & 29.7 & 37.3 & 32.8 & 61.7 \\
\hline Nominal size (mi) & 73.7 & 60.7 & 71.4 & 69.3 & 93.7 \\
\hline Bulk density $\left(\mathrm{kg} / \mathrm{m}^{3}\right.$ ) & 36.9 & 43.2 & 30.7 & 60.7 & 67.6 \\
\hline \multicolumn{6}{|l|}{ Component distribution $(\%)$} \\
\hline Paper and plastic & 96.44 & 89.62 & 89.85 & 78.90 & 47.01 \\
\hline Ferrous metal & 0.00 & 0.23 & 0.00 & 0.00 & 0.00 \\
\hline Nonferrous metal & 0.00 & 0.00 & 1.66 & 3.05 & 0.03 \\
\hline Glass & 0.00 & 0.25 & 0.00 & 1.68 & 1.85 \\
\hline Organic other & 2.40 & 4.84 & 4.35 & 5.91 & 35.73 \\
\hline Inorganic other & 0.00 & 0.07 & 0.00 & 0.19 & 0.00 \\
\hline Fines $(-1.30 \mathrm{~mm})$ & 1.16 & 4.99 & 3.54 & 10.27 & 15.38 \\
\hline
\end{tabular}

(continued) 
TABLE C-12. (continued)

\begin{tabular}{|c|c|c|c|c|c|}
\hline \multirow[b]{2}{*}{ Feedrate $(\mathrm{Mg} / \mathrm{h})$} & \multicolumn{5}{|c|}{$\begin{array}{c}\text { Rotational speed } \\
12 \mathrm{rpm}\end{array}$} \\
\hline & 2.92 & 9.90 & 10.59 & 17.69 & 46.55 \\
\hline Air-dry moisture content $(\%)$ & 10.87 & 14.29 & 17.46 & 23.40 & 9.38 \\
\hline Oven-dry moisture content $(\%)$ & 18.88 & 22.53 & 24.77 & 30.23 & 17.1 \\
\hline As-received ash content $(\%)$ & 7.23 & 7.36 & 15.13 & 18.64 & 15.88 \\
\hline Oven-dry ash content $(\%)$ & 8.91 & 9.50 & 20.11 & 26.72 & 19.16 \\
\hline As-received heating value $(\mathrm{kJ} / \mathrm{kg})$ & 16,802 & 15,884 & 13,995 & 12,363 & 15,719 \\
\hline Oven-dry heating content $(\mathrm{kJ} / \mathrm{kg})$ & 20,713 & 20,504 & 18,603 & 17,719 & 18,971 \\
\hline Ash/energy content $(\mathrm{kg} / \mathrm{GJ})$ & 4.30 & 4.63 & 10.81 & 15.08 & 10.10 \\
\hline Organic content $(\%)$ & 99.03 & 95.71 & 96.83 & 93.73 & 87.53 \\
\hline Characteristic size (mm) & 58.4 & 36.8 & 40.1 & 38.6 & 23.9 \\
\hline Nominal size $(\mathrm{mm})$ & 89.7 & 65.3 & 67.6 & 86.9 & 74.9 \\
\hline Bulk density $\left(\mathrm{kg} / \mathrm{m}^{3}\right)$ & 29.4 & 44.5 & 42.1 & 47.2 & 38.3 \\
\hline \multicolumn{6}{|l|}{ Component distribution $(\%)$} \\
\hline Paper and plastic & 95.36 & 91.37 & 91.73 & 68.17 & 85.70 \\
\hline Ferrous metal & 0.00 & 0.00 & 0.00 & 0.00 & 0.00 \\
\hline Nonferrous metal & 0.00 & 0.00 & 0.00 & 0.01 & 0.10 \\
\hline Glass & 0.00 & 0.01 & 0.02 & 0.29 & 3.93 \\
\hline Organic other & 3.67 & 4.34 & 5.10 & 25.56 & 1.83 \\
\hline Inorganic other & 0.00 & 0.00 & 0.00 & 0.01 & 0.08 \\
\hline Fines $(-1.30 \mathrm{~mm})$ & 0.97 & 4.28 & 3.15 & 5.96 & 8.36 \\
\hline
\end{tabular}


TABLE C-13. PROPERTIES OF UNDERSIZE FRACTIOH - MAY 1981

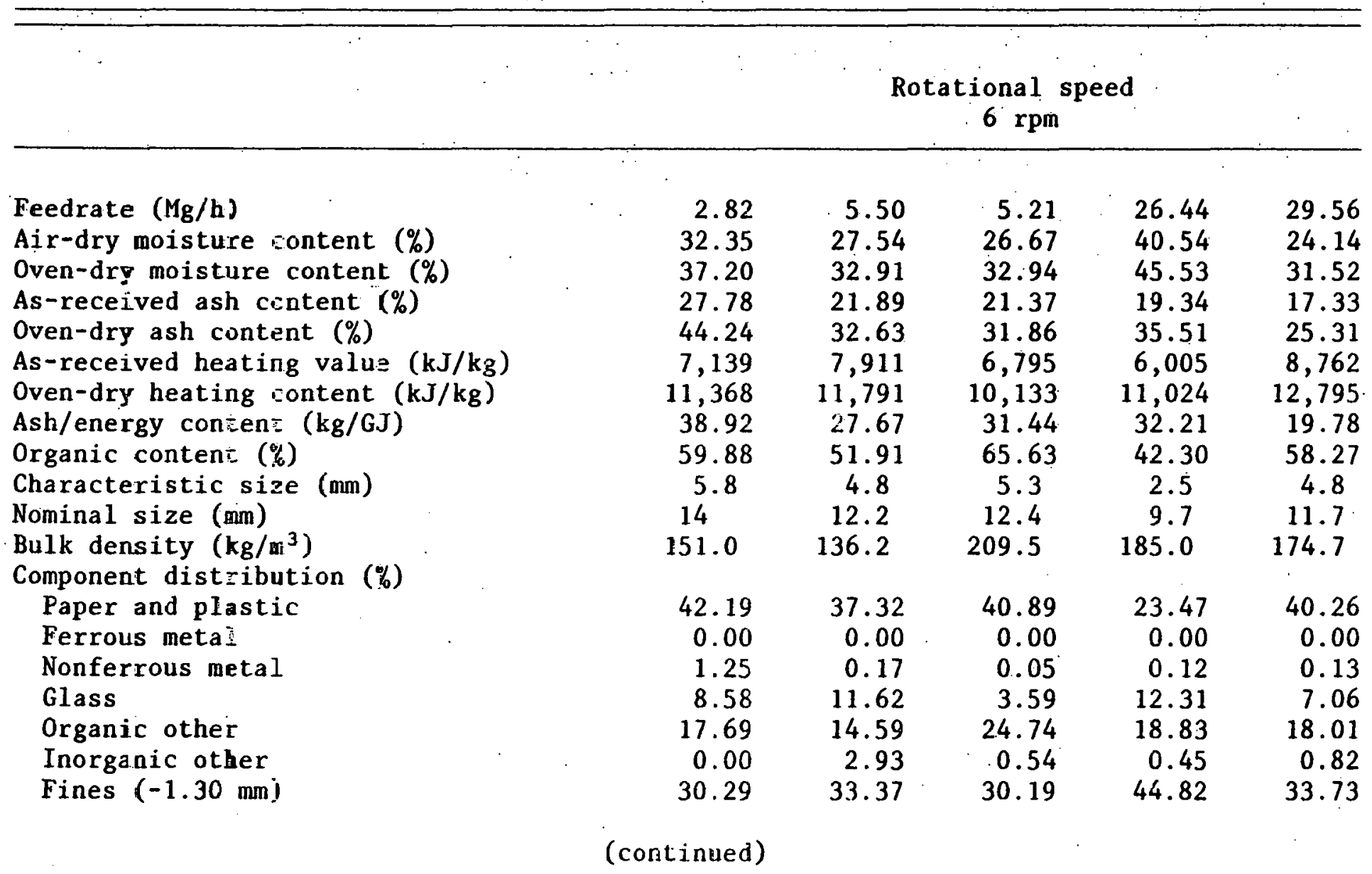


TABLE C-13. (continued)

Rotational speed

$9 \mathrm{rpm}$

\begin{tabular}{|c|c|c|c|c|c|}
\hline Feedrate $(\mathrm{Mg} / \mathrm{h})$ & 6.32 & 6.48 & 8.56 & 31.67 & 32.90 \\
\hline Air-dry moisture content $(\%)$ & 31.58 & 30.57 & 27.45 & 25.22 & 34.52 \\
\hline Oven-dry moisture content $(\%)$ & 36.57 & 36.49 & 32.64 & 30.89 & 38.97 \\
\hline As-received ash contert $(\%)$ & 26.75 & 24.86 & 28.80 & 23.92 & 31.14 \\
\hline Oven-dry ash content $(\%)$ & 42.17 & 39.15 & 42.76 & 34.61 & 51.03 \\
\hline As-received heating value $(\mathrm{kJ} / \mathrm{kg})$ & 8,162 & 8,366 & 8,898 & 6,661 & 7,139 \\
\hline Oven-dry heating content $(\mathrm{kJ} / \mathrm{kg})$ & 12,867 & 13,172 & 13,210 & 9,638 & 11,698 \\
\hline Ash/energy content $\left(\mathrm{k}_{\varepsilon} / \mathrm{GJ}\right)$ & 32.77 & 29.72 & 32.37 & 35.91 & 43.62 \\
\hline Organic content $(\%)$ & 67.88 & 60.18 & 68.87 & 52.73 & 41.21 \\
\hline Characteristic size (mm) & 6.1 & 5.6 & 7.1 & 4.1 & 2.8 \\
\hline Nominal size (mm) & 15.2 & 15.2 & 15.0 & 9.9 & 9.7 \\
\hline Bulk density $\left(\mathrm{kg} / \mathrm{m}^{3}\right)$ & 164.6 & 146.4 & 105.1 & 202.6 & $172.9^{\circ}$ \\
\hline Component distribution $(\%)$ & (2). & & & & \\
\hline Paper and plastic & 47.61 & 36.63 & 54.59 & 37.01 & 24.81 \\
\hline Ferrous metal & 0.14 & 0.17 & 0.00 & 0.00 & 0.00 \\
\hline Nonferrous metal & 0.02 & 0.71 & 0.22 & 0.07 & 0.00 \\
\hline Glass & 3.34 & 5.28 & 2.84 & 11.27 & 14.51 \\
\hline Organic other & 20.27 & 23.55 & 14.28 & 15.72 & 16.40 \\
\hline Inorganic other & 0.00 & 0.16 & 0.18 & 0.00 & 0.58 \\
\hline Fines $(-1.30 \mathrm{~mm})$ & 28.62 & 31.50 & 27.89 & 35.93 & 43.70 \\
\hline
\end{tabular}


TABLE C-13. (continued)

Rotational speed

$12 \mathrm{rpm}$

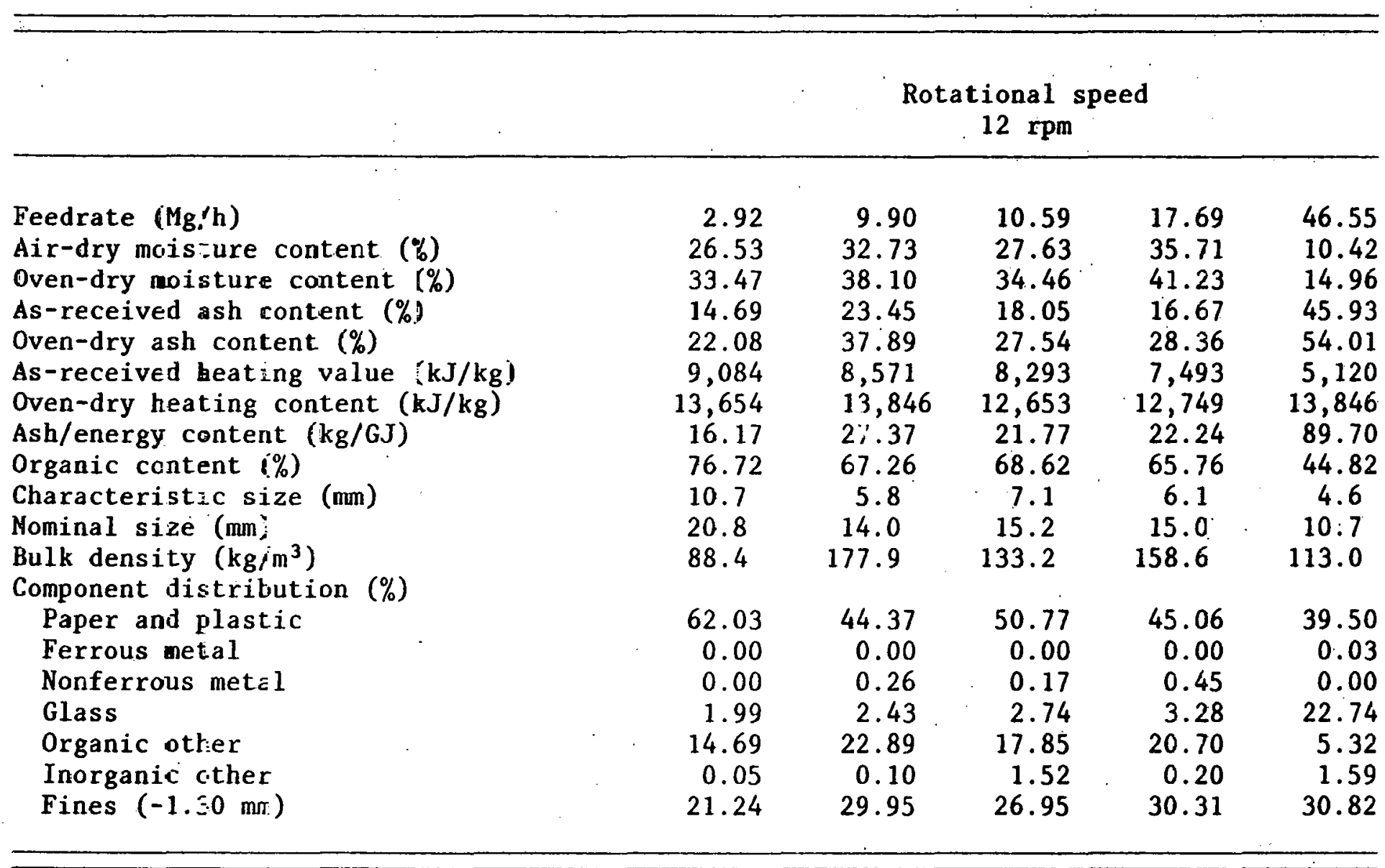


TABLE C-14. TROMMEL PERFORMANCE CHARACTERIZATION - AUGUST 1981

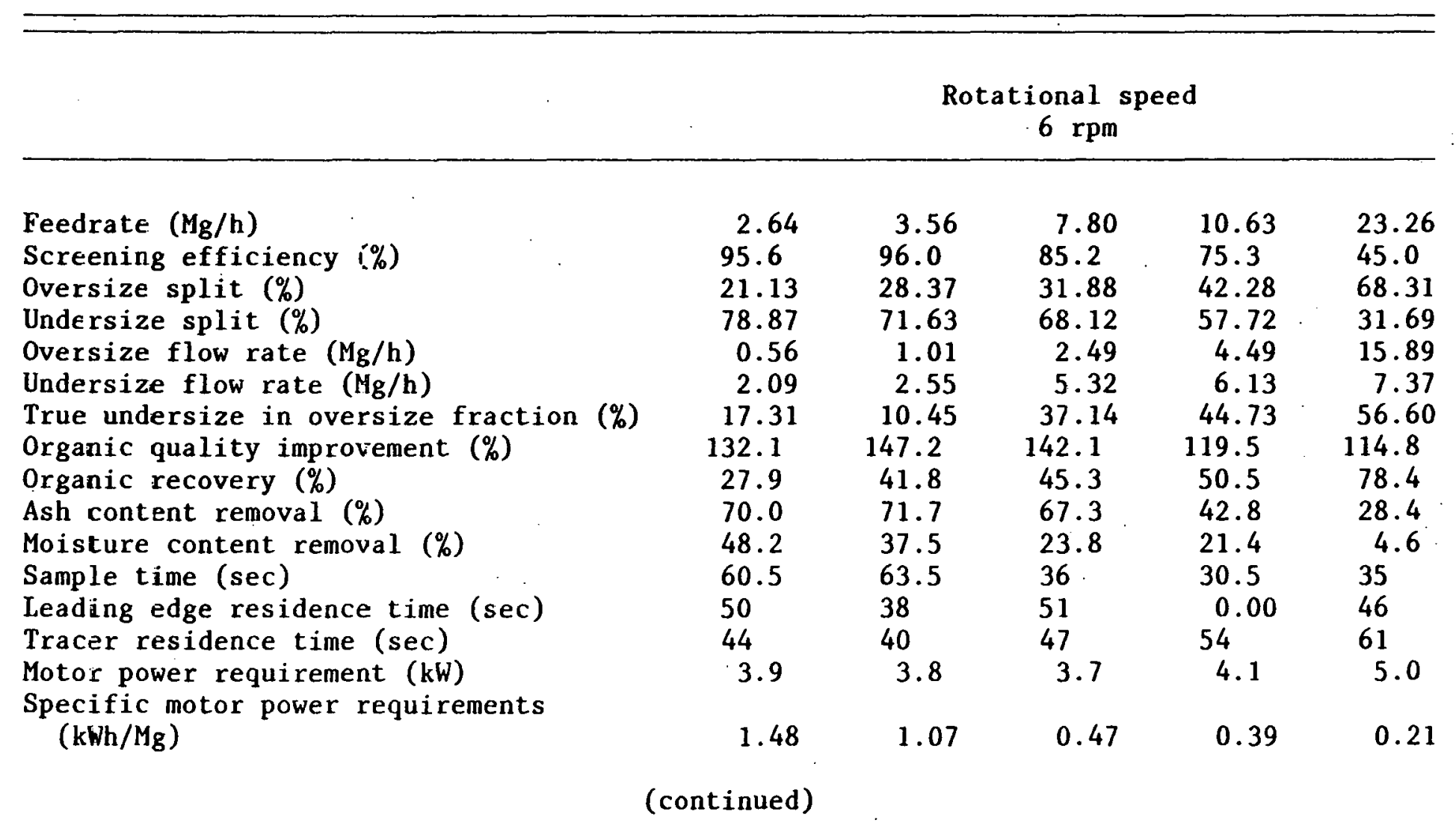


TABLE C-14. (continued)

Rotational speed

$9 \mathrm{rpm}$

Feedrate $(\mathrm{Mg} / \mathrm{h})$
Screening efficiency $(\%)$
Oversize split $(\%)$
Undersize split $(\%)$
Oversize flow rate $(\mathrm{Mg} / \mathrm{h})$
Undersize flow rate $(\mathrm{Mg} / \mathrm{h})$
True undersize in oversize fraction $(\%)$
Organic quality improvement (\%)
Organic recovery $(\%)$
Ash content remcval $(\%)$
Moisture content removal (\%)
Sample time (sec)
Leading edge residence time (sec)
Tracer residence time (sec)
Motor power requirement (kW)
Specific motor power requirements
(kWh/Mg)

$\begin{array}{ccccc}1.47 & 6.91 & 10.17 & 12.7 .1 & 33.28 \\ 9.79 & 86.7 & 88.4 & 65.9 & 37.1 \\ 18.37 & 29.81 & 32.22 & 49.88 & 73.11 \\ 81.63 & 70.19 & 67.78 & 50.12 & 26.89 \\ 0.27 & 2.06 & 3.28 & 6.34 & 24.33 \\ 1.20 & 4.85 & 6.90 & 6.37 & 8.95 \\ 9.40 & 36.18 & 27.63 & 51.91 & 62.24 \\ 133.0 & 129.7 & 128.8 & 120.4 & 110.2 \\ 24.4 & 38.7 & 41.5 & 60.1 & 80.6 \\ 61.1 & 68.3 & 66.7 & 37.8 & 28.1 \\ 55.0 & 15.4 & 44.3 & 7.5 & 4.7 \\ 76.5 & 34 & 39 & 46 & 37 \\ 43 & 38 & 40 & 39 & 35 \\ 49 & 36 & 33 & 48 & 49 \\ 3.8 & 3.9 & 4.0 & 4.2 & 4.9 \\ 2.59 & 0.56 & 0.39 & 0.33 & 0.15\end{array}$

(continued) 
TABLE $\mathrm{C}-14$. (continued)

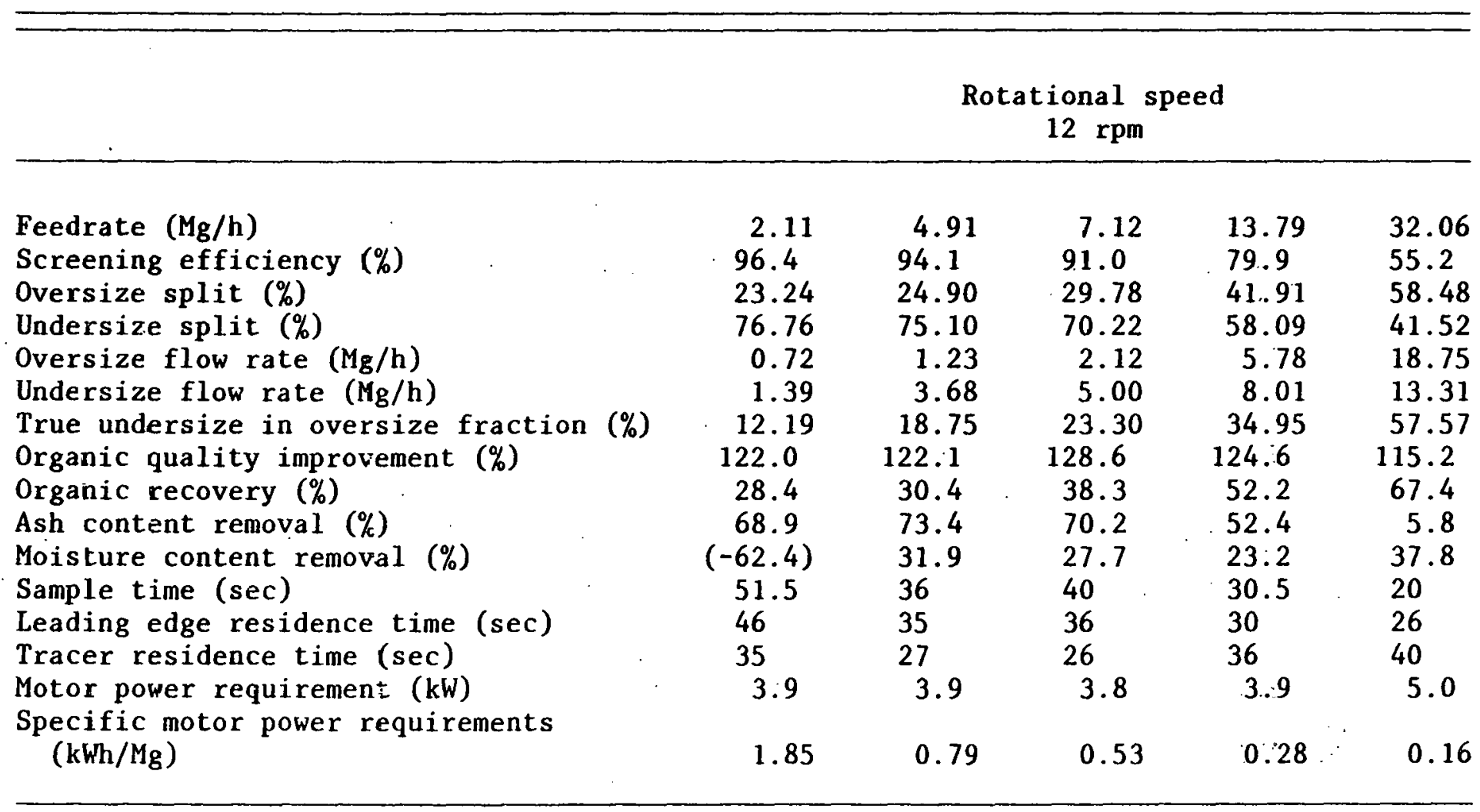


TABLE C-15. PROPERTIES OF FEED MATERIAL - AUGUST 1981

Rotational speed

$6 \mathrm{rpm}$

\begin{tabular}{lrrrrr}
\hline & & & & \\
Feedrate (Mg/h) & 2.64 & 3.56 & 7.80 & 10.63 & 23.26 \\
Air-dry moisture content (\%) & 28.36 & 26.27 & 34.74 & 26.59 & 25.03 \\
Oven-dry moisture content (\%) & 33.22 & 32.09 & 39.71 & 31.37 & 29.80 \\
As-received ash content (\%) & 23.63 & 18.43 & 18.76 & 17.55 & 22.06 \\
Oven-dry ash cortert (\%) & 35.39 & 27.14 & 31.12 & 27.55 & 31.42 \\
Organic content (\%) & 73.37 & 65.79 & 65.47 & 76.07 & 73.13 \\
True oversize content (\%) & 17.65 & 25.63 & 21.28 & 23.46 & 29.66 \\
Characteristic size (mm) & 9.5 & 11.7 & 10.8 & 13.9 & 17.4 \\
Nominal size (mn) & 46.9 & 58.7 & 46.6 & 26.4 & 64.4 \\
Component distribution (\%) & & & & 6.4 \\
Paper and plastic & 61.78 & 57.76 & 64.45 & 68.26 & 62.87 \\
Ferrous metal & 0.02 & 0.16 & 0.06 & 0.05 & 0.00 \\
Nonferrous metal & 0.62 & 0.88 & 0.58 & 0.83 & 0.63 \\
Glass & 3.93 & 8.38 & 4.79 & 4.38 & 5.71 \\
Organic other & 11.59 & 8.03 & 10.11 & 7.82 & 10.25 \\
Inorganic other & 0.40 & 1.76 & 0.75 & 0.84 & 0.80 \\
Fines (-1.30 mm) & 21.66 & 23.03 & 19.26 & 17.82 & 19.74
\end{tabular}

(continued) 
TABLE C-15. (continued)

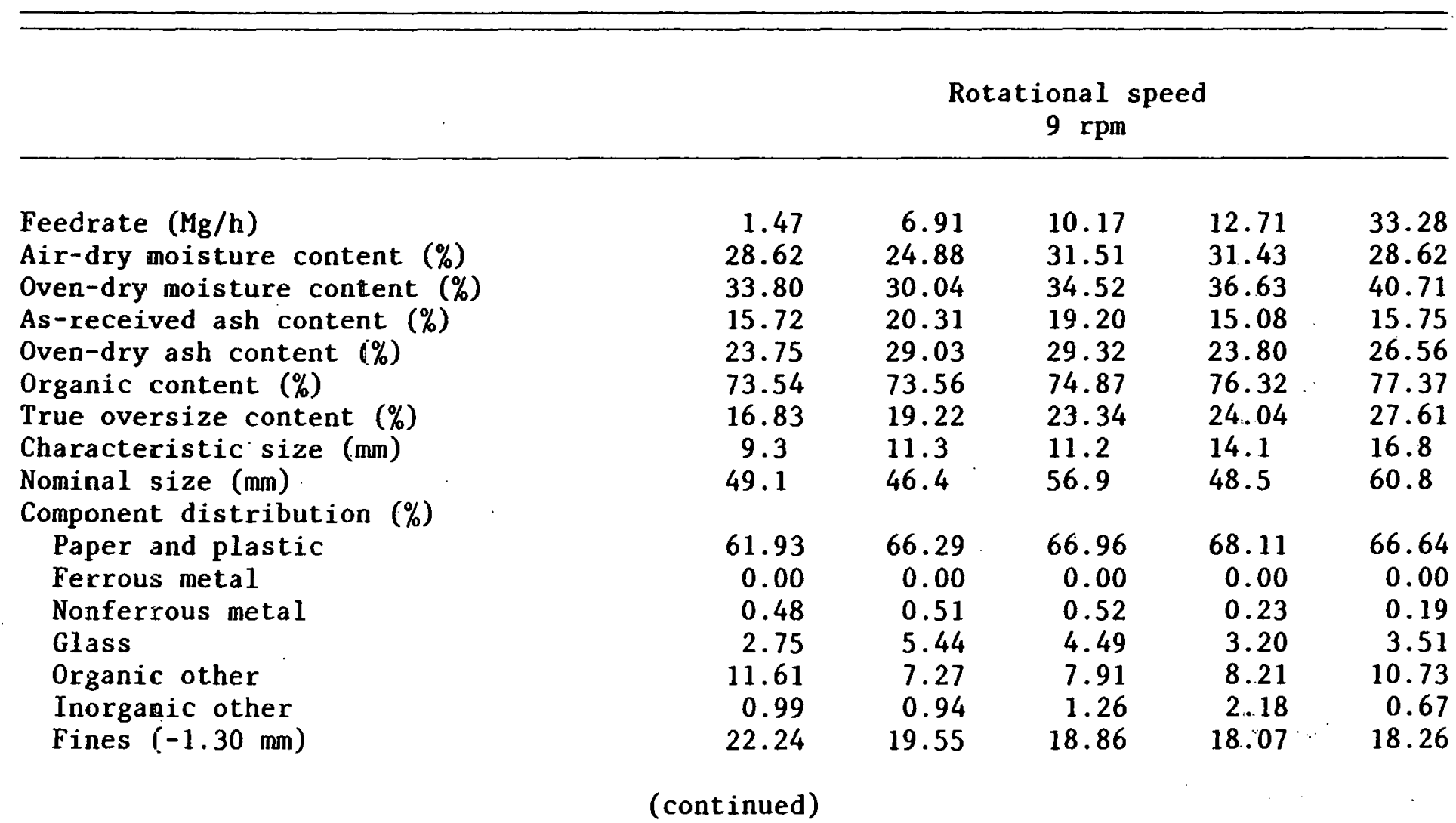


TABLE C-15. (continued)

\section{Rotational speed}

$12 \mathrm{rpm}$

Feedrate $(\mathrm{Mg} / \mathrm{h})$

Air-dry noisture content (\%)

Oven-dry moisture content (\%)

As-receired ash content (\%)

Oven-dry ash cantent (\%)

Organic content (\%)

True oversize content (\%)

Characteristic size (mm)

Nominal size ( $\mathrm{rm})$

Component distribution (\%)

Paper and plastic

Ferrous metal

Nonferrous metal

Glass

Organi: other

Inorganic other

Fines $(-1.30 \mathrm{~mm})$

$\begin{array}{rrrrr}2.11 & 4.91 & 7.12 & 13.79 & 32.06 \\ 34.48 & 29.56 & 34.34 & 31.39 & 25.86 \\ 40.41 & 35.41 & 39.07 & 36.30 & 30.79 \\ 11.73 & 21.10 & 22.58 & 13.42 & 13.44 \\ 19.69 & 32.66 & 37.06 & 21.06 & 25.45 \\ 78.19 & 80.48 & 72.07 & 75.84 & 75.81 \\ 22.14 & 20.49 & 23.11 & 27.27 & 24.83 \\ 14.2 & 13.2 & 12.3 & 14.6 & 16.2 \\ 49.1 & 46.1 & 52.8 & 50.6 & 50.8 \\ & & & & \\ 63.29 & 68.49 & 66.15 & 67.32 & 62.97 \\ 0.00 & 0.04 & 0.58 & 0.00 & 0.20 \\ 1.61 & 0.49 & 0.97 & 0.12 & 0.24 \\ 3.36 & 2.39 & 6.40 & 4.24 & 4.34 \\ 14.90 & 11.98 & 5.90 & 8.52 & 12.84 \\ 1.27 & 0.70 & 2.45 & 1.64 & 1.16 \\ 15.57 & 15.91 & 17.55 & 18.16 & 18.25\end{array}$

32.06

25.86

.79

25.45

75.81

4.83

2.97

0.20

0.24

4.34

1.16

18.25 
TABLE C-16. PROPERTIES OF OVERSIZE FRACTION - AUGUST 1981

\begin{tabular}{|c|c|c|c|c|c|}
\hline & \multicolumn{5}{|c|}{$\begin{array}{c}\text { Rotational speed } \\
6 \mathrm{rpm}\end{array}$} \\
\hline Feedrate $(\mathrm{Mg} / \mathrm{h})$ & 2.64 & 3.56 & 7.80 & 10.63 & 23.26 \\
\hline Air-dry moisture content (\%) & 10.50 & 14.01 & 24.95 & 18.43 & 23.22 \\
\hline Oven-dry moisture content $(\%)$ & 17.22 & 20.05 & 30.25 & 24.65 & 28.44 \\
\hline As-received ash contert $(\%)$ & 7.09 & 5.22 & 6.14 & 10.04 & 15.79 \\
\hline Oven-dry ash content $(\%)$ & 8.56 & 6.53 & 8.80 & 13.33 & 22.07 \\
\hline Organic content $(\%)$ & 96.93 & 96.84 & 93.00 & 90.93 & 83.92 \\
\hline Characteristic size (mm) & 55.0 & 57.6 & 42.5 & 38.1 & 31.7 \\
\hline Nominal size $(\mathrm{mm})$ & 85.2 & 79.8 & 68.9 & 64.5 & 75.7 \\
\hline Bulk density $\left(\mathrm{kg} / \mathrm{m}^{3}\right)$ & 70.8 & 74.6 & 98.2 & 105.7 & 107.0 \\
\hline \multicolumn{6}{|l|}{ Component distribution $(\%)$} \\
\hline Paper and plastic & 92.01 & 93.66 & 88.81 & 83.70 & 72.21 \\
\hline Ferrous metal & 0.00 & 0.00 & 0.00 & 0.11 & 0.00 \\
\hline Nonferrous metal & 2.46 & 2.18 & 0.85 & 1.59 & 0.87 \\
\hline Glass & 0.00 & 0.00 & 0.32 & 0.48 & 1.38 \\
\hline Organic other & 4.92 & 3.37 & 4.19 & 7.24 & 11.71 \\
\hline Inorganic other & 0.00 & 0.00 & 0.23 & 0.15 . & 0.32 \\
\hline Fines $(-1.30 \mathrm{~mm})$ & 0.61 & 0.79 & 5.60 & 6.73 & 13.51 \\
\hline
\end{tabular}


TABLE $E-16$. (continued)

\section{Rotational speed}

$9 \mathrm{rpm}$

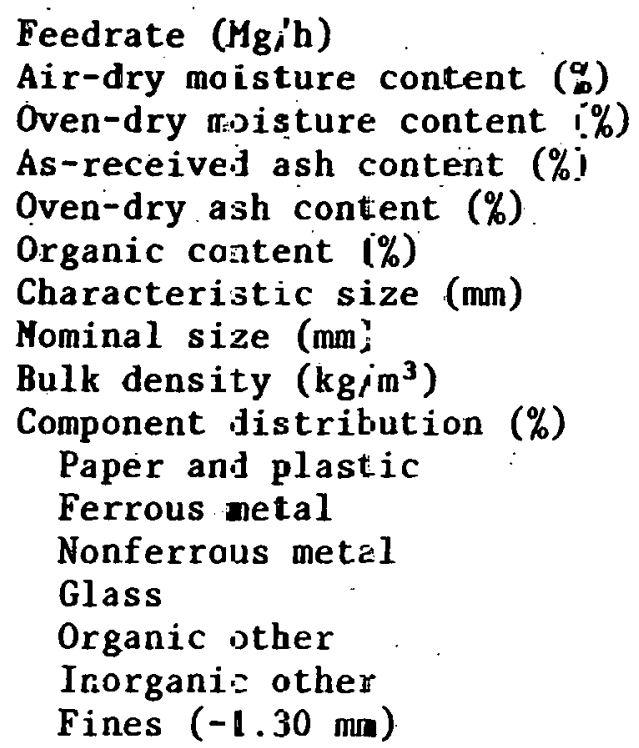

$\begin{array}{rcccc}1.47 & 6.91 & 10.17 & 12.71 & 33.28 \\ 8.54 & 19.60 & 20.78 & 28.50 & 8.54 \\ 15.20 & 25.41 & 19.24 & 33.88 & 38.78 \\ 6.12 & 6.43 & 6.40 & 9.38 & 11.33 \\ 7.22 & 8.62 & 7.92 & 14.18 & 18.51 \\ 97.7 .8 & 95.40 & 96.46 & 91.88 & 85.26 \\ 63.4 & 43.9 & 51.4 & 34.5 & 25.8 \\ 88.8 & 70.2 & 77.8 & 66.9 & 69.2 \\ 43.6 & 7 j .9 & 89.5 & 110.7 & 102.0 \\ & & & & \\ 97.24 & 85.98 & 92.43 & 85.77 & 74.25 \\ 0.00 & 0.00 & 0.00 & 0.00 & 0.00 \\ 1.67 & 0.52 & 0.84 & 0.06 & 0.25 \\ 0.00 & 0.16 & 0.22 & 0.66 & 1.56 \\ 0.54 & 9.41 & 4.02 & 6.12 & 10.99 \\ 0.00 & 0.11 & 0.10 & 0.13 & 0.52 \\ 0.55 & 3.82 & 2.39 & 7.26 & 12.43\end{array}$


TABLE C-16. (continued)

Rotational speed

$12 \mathrm{rpm}$

\begin{tabular}{lrrrrr}
\hline & & & & \\
Feedrate (Mg/h) & 2.11 & 4.91 & 7.12 & 13.79 & 32.06 \\
Air-dry moisture content (\%) & 63.13 & 18.39 & 22.76 & 22.54 & 13.21 \\
Oven-dry moisture content (\%) & 65.63 & 24.11 & 28.25 & 27.89 & 19.16 \\
As-received ash content (\%) & 3.65 & 5.62 & 6.73 & 6.39 & 12.66 \\
Oven-dry ash content (\%) & 10.63 & 7.40 & 9.38 & 8.86 & 15.66 \\
Organic content (\%) & 95.40 & 98.23 & 92.91 & 94.47 & 87.30 \\
Characteristic size (m) & 48.9 & 47.7 & 50.1 & 42.5 & 29.8 \\
Nominal size (mm) & 23.4 & 68.9 & 74.3 & 68.6 & 63.4 \\
Bulk density (kg/m ${ }^{3}$ ) & 62.1 & 69.7 & 89.5 & 88.3 & 103.2 \\
Component distribution (\%) & & & & & \\
Paper and plastic & 89.86 & 90.53 & 92.69 & 90.65 & 72.47 \\
Ferrous metal & 0.01 & 0.00 & 0.66 & 0.00 & 0.12 \\
Nonferrous metal & 4.12 & 0.58 & 2.24 & 0.20 & 0.18 \\
Glass & 0.00 & 0.00 & 0.05 & 0.16 & 1.45 \\
Organic other & 5.54 & 7.70 & 2.33 & 3.82 & 14.82 \\
Inarganic other & 0.00 & 0.00 & 0.58 & 0.11 & 0.41 \\
Fines (-1.30 mm) & 0.47 & 1.19 & 1.45 & 5.06 & 10.55 \\
& & & & \\
\hline
\end{tabular}


TABLE C-17. PROPERTIES OF UNDERSIZE FRACTION - AUGUST 1981

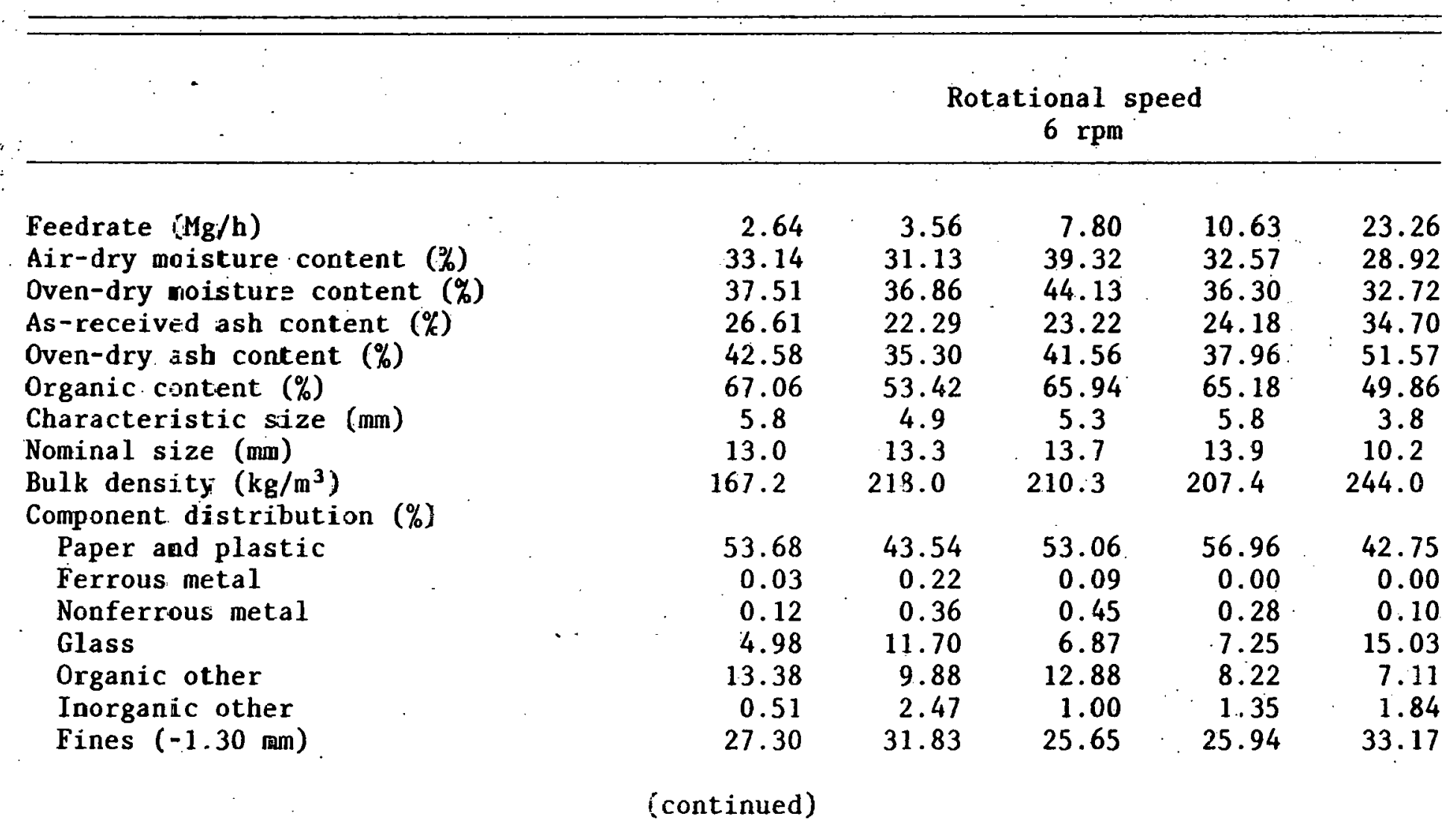


TABLE $\mathrm{C}-17 . \quad$ (continued)

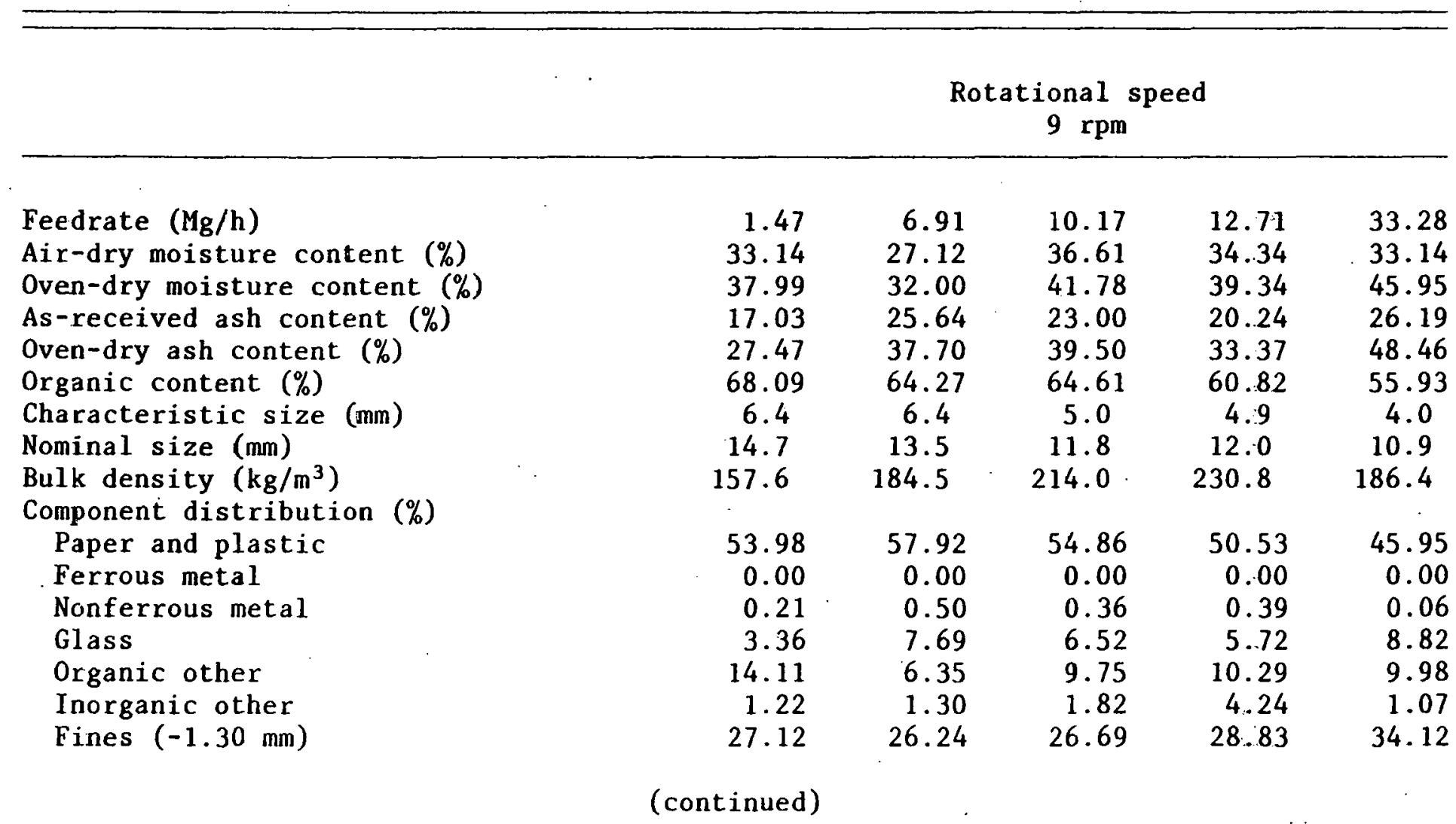


TABLE" $\mathrm{C}-17$. (cont inued)

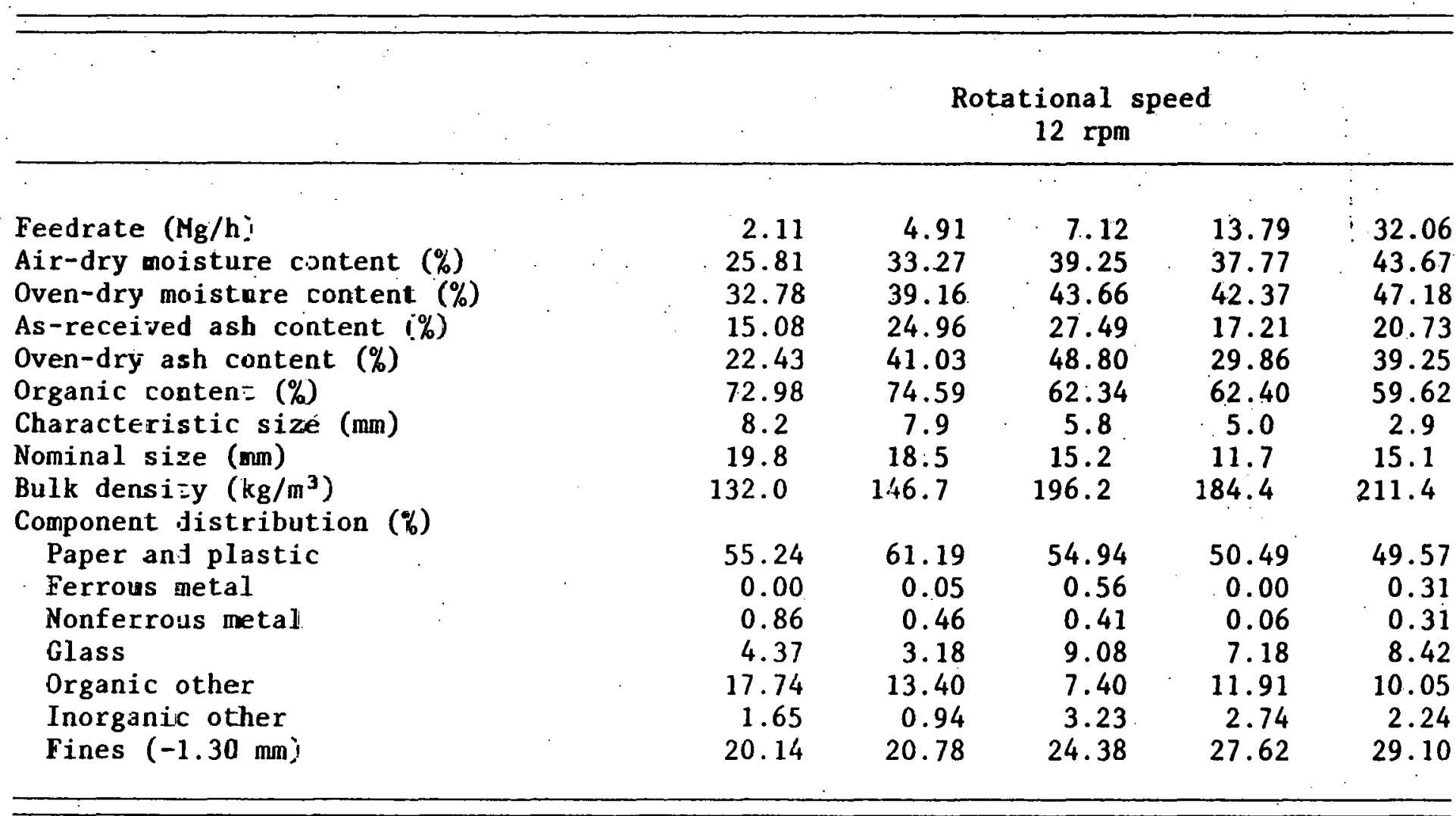


$+1$

APPENDIX D

MAINTENANCE, OPERATION, AND ECONOMIC CONTRIBUTION

D-1 


\begin{tabular}{|c|c|c|c|c|}
\hline \multirow{3}{*}{$\begin{array}{c}\text { Date } \\
(1980)\end{array}$} & \multicolumn{2}{|c|}{ Labor Hours } & \multirow{2}{*}{ Materials } & \\
\hline & Day & Night & & \multirow[b]{2}{*}{ Maintenance activity } \\
\hline & shift & shift & Description & \\
\hline
\end{tabular}

Nov. 26

Nov. 28

Dec. 1

Dec. 8

Dec. 26

(1981)

Jan. 6

Jan. 12

Jan., 13

Jan. 14

Jan. 15

$\mathrm{Jan} \cdot 26$

Jan. 27

Jan. 28

Feb. 9

Feb. 10

Feb. 13

Feb. 14

Mar. 13

Mar. 14

Mar. 16

Mar. 19

Mar. 20

Mar. 23

Mar. 30

Apr. ?

Apr. 11

Apr . 12

Apr. 13

ApE. 14

Apr. 15

Apr. 23-30

Apt. 30

May 14

July 5

July 20

oce. 6

Oct. 27

Total

12

2.5

6

3

24

1

1.5

1

4

3.5

1

1.5

6

3

8

3

24

16

8.

4

8

welding rod

Weld rod

1/2 ill. 3teel plate

$1 / 2$ in. Steel
plate

Welding rod

Weldiog rod

Welding rot

Welding rod

Welding rod

None

Dexron oil

Weld rod

Dexron oil

Dexron oil

Grease and $1 / 2$ chain link

\section{* Lubricate entire tromel.}

* Disassemble, clean, and reassemble drive wheel.

Drive wheel had come loose and jamed against tromel housing. Drill new set holes, clean and replace drive wheel. Inspect clutch assembly.

Set screw sheared. Clear out same, drill set hole deeper, reposition lopse dripe wheel, install new set screw bolts with Loctite.

Lubricate wheẹl bearịngs.

Weld broken lifter bar and screen.

Dismantle, repait, replace worn drive wheel.

Lubricate entire tromel.

Mount new tire and rim (automobile tires used as additional support)

Replenish oil in clutch housiags.

Change sheaves.

Grind out and weld fractures in carrier ring. Adjust vari-speed sheave.

Adjust vari-speed sheave.

Weld broken lifter bar.

Weld wheel and stop plate to drive shaft.

Install new drive wheel assembly.

Install new clutches.

Weld cracked carrier ring and broken screen. Grind out and weld fractures in carrier ring. Weld steel plate for added strength inside trommel.

Continue with March 13 work.

Install. ten $1 / 2$ in. $x 10$ in. $x 44$ iu. steel plates and twenty $1 / 2$ in. $x 6$ in. $x 8$ in. steel gussets inside the cromel around circiuiference of the drive wheel cleaned track for structural strength.

weld $1 / 2$ in. place inside tromnel.

Same as March 19.

Repair cracked welds on discharge chute to eliminate material spillage.

Inotuld twmity $1 / 2$ in, $x 3$ in, $x 6$ in, steel plat.es to strengthen carrier rings by welding the plates insite the trommel across the area of the ring joints.

Install five $1 / 2$ in. $x 3$ in. $\times 6$ in. steel plates as pèt Mar. 30 .

Weld cracked carrier ring.

Same as April 11.

Same as April 11.

Same as April 12.

Same as April 11.

Fabricate and install new carrier ring by outside contraotor.

Clean up after contractor and adjust feed conveyor. Chauge vil in clutchcs.

Reweld loose trunaion wheel.

Change oil in clutches.

Replenish oil in clutches.

Lubricate entire tromel. Tighten drive chain by removing $1 / 2$ link. 
TABLE D-2. TONS OF ARDF PELIEFS SIIIPPED TO WRIGIIT-PATTERSON AIR FORCE BASF:

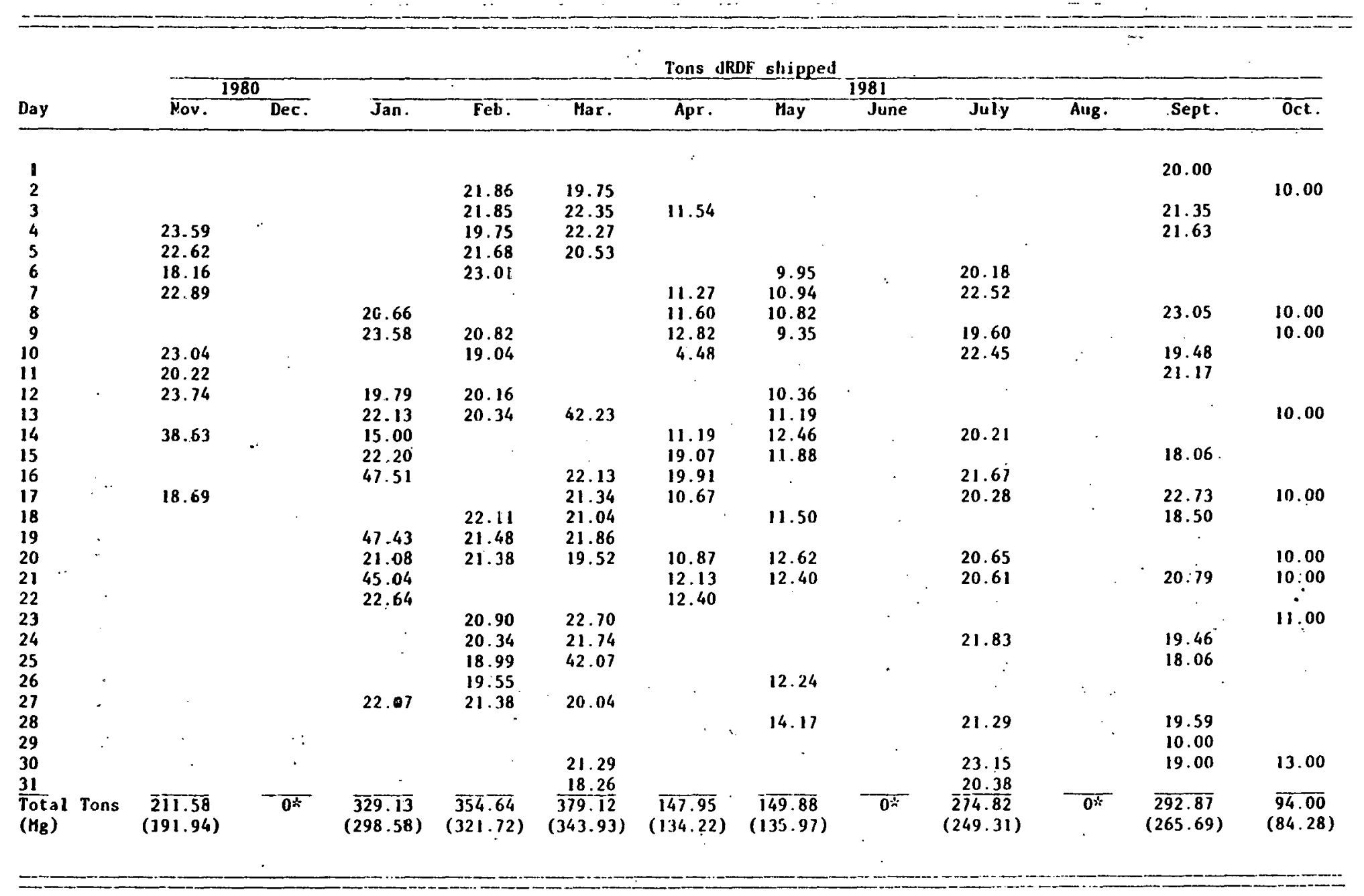

Wo pellets shipped during these months, IRIJf placed in warehouse for later shipment. 
TABI.E D-3. DALLY HOURS OF TROMNEj. OPERATION

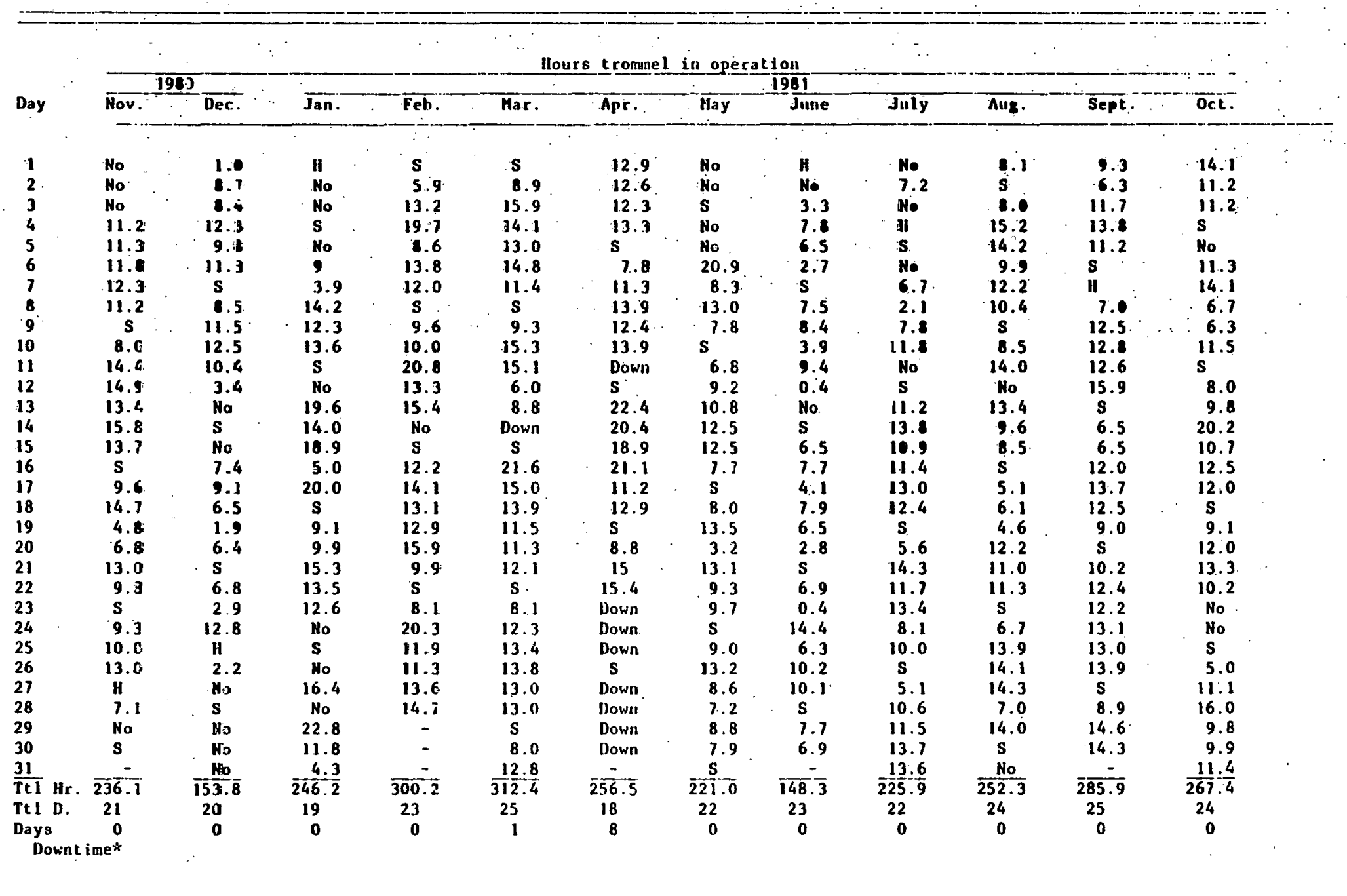

Legend: $S=$ Sunday; $I$ = Holiday; No = RDF facility not in operation; lown = plant woult have operated if trommel not slust down.

$*$ Days downt ine for tromuel only. 
TARLE: 10-4. ECONOMIC CONTRIDUTION OF TROMNFL

\begin{tabular}{|c|c|c|c|c|c|c|c|c|c|}
\hline $\begin{array}{l}\text { Rotational } \\
\text { speed } \\
\text { RPM }\end{array}$ & $\begin{array}{c}\text { Feedrate } \\
\qquad \mathrm{Mg}_{\mathrm{g}} / \mathrm{h}\end{array}$ & $\begin{array}{c}\text { Oversize } \\
\text { split } \\
\text { \% }\end{array}$ & $\begin{array}{l}\text { Oversize } \\
\text { flow rate } \\
\mathrm{Mg} / \mathrm{h}\end{array}$ & InIecil & $\begin{array}{r}n \text { dry heatin } \\
\text { kJ/kg } \\
\text { Oversize }\end{array}$ & Increase & $\begin{array}{c}\text { Value of heating* } \\
\text { value increase } \\
\$ / \mathrm{Hg}_{\mathrm{g}}\end{array}$ & $\begin{array}{l}\text { Cost of } \% \\
\text { tromine l } \\
\$ / \mathrm{Hg}\end{array}$ & $\begin{array}{c}\text { ficonumict } \\
\text { contribution of } \\
\text { trommel } \$ / \mathrm{Mg}_{\mathrm{g}}\end{array}$ \\
\hline \multicolumn{10}{|l|}{ Oct. 1980} \\
\hline 6 & 1.76 & 36.08 & 10.64 & $17,4.15$ & 20,810 & 3,395 & 6.68 & 9.65 & -2.97 \\
\hline 6 & 3.13 & 49.31 & 1.54 & 17,749 & 19,775 & 2,026 & 3.99 & 3.97 & 0.02 \\
\hline 6 & 4.74 & 29.39 & 1.39 & 18,547 & 19,932 & 1,385 & 2.73 & 4.40 & -1.67 \\
\hline 6 & 23.91 & 76.09 & 18.19 & 18,947 & 19,219 & 272 & 0.54 & 0.34 & 0.20 \\
\hline 9 & 2.82 & 45.87 & 1.29 & 18,732 & 20,719 & 1,987 & 3.91 & 4.74 & -0.83 \\
\hline 9 & 5.85 & 38.07 & 2.23 & 17,827 & 20,552 & 2,725 & 5.36 & 2.75 & 2.61 \\
\hline 9 & 10.55 & 69.75 & 7.36 & 18,662 & 22,123 & 3,461 & 6.81 & 0.83 & 5.98 \\
\hline 9 & 15.86 & 64.77 & 10.27 & 16,524 & 19,631 & 3,107 & 6.11 & 0.60 & 5.51 \\
\hline 9 & 22.55 & 64.51 & 14.51 & 16,456 & 18,964 & 2,508 & 4.94 & 0.42 & 4.52 \\
\hline 12 & 3.43 & 35.48 & 1.22 & 17,587 & 23,847 & 6,260 & 12.32 & 5.04 & 7.28 \\
\hline 12 & 9.11 & 63.70 & 5.80 & 16,902 & 20,284 & 3,382 & 6.66 & 1.06 & 5.60 \\
\hline 12 & 13.62 & 44.49 & 6.06 & 18,266 & 20,834 & 2,568 & 5.05 & 1.01 & 4.04 \\
\hline 12 & 30.27 & 68.53 & 20.74 & 18,743 & 20,743 & 2,000 & 3.94 & 0.30 & 3.64 \\
\hline \multicolumn{10}{|l|}{ Hay 1991} \\
\hline 6 & 2.82 & 38.26 & 1.08 & 14,516 & 19,608 & 5,092 & 10.02 & 5.68 & 4.34 \\
\hline 6 & 5.05 & 29.84 & 1.51 & 14,097 & 19,503 & 5,406 & 10.64 & 4.07 & 6.57 \\
\hline 6 & 5.21 & 18.93 & 0.99 & 12,009 & 20,060 & 8,051 & 15.84 & 6.22 & 9.62 \\
\hline 6 & 26.44 & 79.25 & 20.95 & 13,136 & 13,687 & 551 & 1.08 & 0.29 & t† \\
\hline 6 & 29.56 & 80.64 & 23.84 & $17 ., 766$ & 18,963 & 1,197 & 2.36 & 0.26 & 2.10 \\
\hline 9 & 6.32 & 29.09 & 1.84 & 14,401 & 18,138 & 3,737 & 7.35 & 3.33 & 4.02 \\
\hline 9 & 6.48 & 52.55 & 3.41 & 16,830 & 20,127 & 3,297 & 6.49 & 1.80 & $+t$ \\
\hline 9 & 8.56 & 52.58 & 4.50 & 16,685 & 19,817 & 3,132 & 6.16 & 1.36 & 4.80 \\
\hline 9 & 31.67 & 67.41 & 21.35 & 16,109 & 19,239 & 3,130 & 6.16 & 0.29 & 5.87 \\
\hline 9 & 32.90 & 74.43 & 24.49 & 18,411 & 20,721 & 2,310 & 4.55 & 0.25 & 4.30 \\
\hline 12 & 2.92 & 63.72 & 1.86 & 18,151 & 20,713 & 2,562 & 5.04 & 3.29 & 1.75 \\
\hline 12 & 9.90 & 38.91 & 3.85 & 16,436 & 20,504 & 4,068 & 8.01 & 1.59 & 6.42 \\
\hline 12 & 10.59 & 56.04 & 5.93 & 15,985 & $.18,603$ & 2,618 & 5.15 & 1.03 & ++ \\
\hline 12 & 17.69 & 60.93 & 10.78 & 15,776 & 17,719 & 1,943 & 3.82 & 0.57 & $+t$ \\
\hline 12 & 46.55 & 81.97 & 38.16 & 16,640 & 18,971 & 2,331 & 4.59 & 0.16 & $+t$ \\
\hline
\end{tabular}

* Value of heating value increase $=\mathrm{kJ} / \mathrm{kg}$ increase $\frac{x}{M g} \$ 1.968 / 10^{6} \mathrm{~kJ}=\$ / \mathrm{Mg}$ of oversize

$\therefore$ Cost of tronnel $=\quad \$ 6.13 / \mathrm{h}$

$\overline{H g} /$ h oversize fow rate $=\$ / H_{8}$ of oversizc

1 Economic contribution $=$ value of heating value increase - cost of trommel = \$/Hg of oversize material

11 Heating value fuel specification iot nert. Heating value below $15,119 \mathrm{~kJ} / \mathrm{kg}$ dry basis

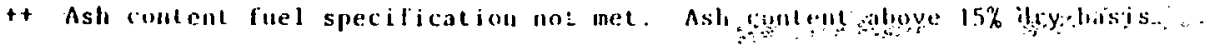

